\author{
UNIVERSIDADE DE SÃO PAULO \\ PROGRAMA DE PÓS-GRADUAÇÃO EM GEOGRAFIA FÍSICA \\ FACULDADE DE FILOSOFIA, LETRAS E CIÊNCIAS HUMANAS \\ DEPARTAMENTO DE GEOGRAFIA
}

IVONETE DE ALMEIDA SOUZA DOMINGUES

Variabilidade climática e sua influência na produtividade da cultura da cana-de-açúcar (Saccharum spp) na região norte e noroeste do Paraná 
IVONETE DE ALMEIDA SOUZA DOMINGUES

\title{
Variabilidade climática e sua influência na produtividade da cultura da cana-de- açúcar (Saccharum spp) na região norte e noroeste do Paraná
}

\begin{abstract}
Tese apresentada ao Programa de Pósgraduação em Geografia Física da Faculdade de Filosofia, Letras e Ciências Humanas da Universidade de São Paulo, como parte dos requisitos para obtenção do grau de doutor em Ciências (Geografia Física).
\end{abstract}

Orientador: Prof ${ }^{\circ}$. Dr. Emerson Galvani

São Paulo 
Autorizo a reprodução e divulgação total ou parcial deste trabalho, por qualquer meio convencional ou eletrônico, para fins de estudo e pesquisa, desde que citada a fonte.

\section{Catalogação na publicação \\ Serviço de Biblioteca e Documentação}

Faculdade de Filosofia, Letras e Ciência Humanas da Universidade de São Paulo

Domingues, Ivonete de Almeida Souza.
Variabilidade climática e sua influência na produtividade
da cultura da cana-de-açúcar (Saccharum spp) na região norte e noroeste
do Paraná / Ivonete de Almeida Souza Domingues; orientador Emerson
Galvani. -- São Paulo, 2010.
235 f. : il.
Tese (Doutorado)--Faculdade de Filosofia, Letras e Ciências Humanas
da Universidade de São Paulo. Departamento de Geografia. Área de
concentração: Geografia Física.
1. Influência climática. 2. Agroclimatologia. 3. Cana-de-açúcar. I.
Título. II. Galvani, Emerson.
CDD 910.2


Nome: Domingues, I. de A. S.

Título: Variabilidade climática e sua influência na produtividade da cultura da canade-açúcar (Saccharum spp) na região norte e noroeste do Paraná

Tese apresentada ao Programa de Pós-graduação em Geografia Física da Faculdade de Filosofia, Letras e Ciências Humanas da Universidade de São Paulo para obtenção do título de Doutor em Geociências (Geografia Física).

Aprovado em:

Banca Examinadora

Prof. Dr.

Instituição:

Assinatura:

Prof. Dr.

Instituição:

Assinatura:

Prof. Dr.

Instituição:

Assinatura:

Prof. Dr.

Instituição:

Assinatura:

Prof. Dr.

Instituição: Assinatura: 


\section{AGRADECIMENTOS}

Ao professor Dr. Emerson Galvani, pela orientação e amizade.

A Coordenação de Aperfeiçoamento de Pessoal de Nível Superior (CAPES), pela concessão da bolsa de doutorado, essencial para a realização desta pesquisa.

Ao programa de Pós-Graduação em Geografia - FFLCH/USP, SP, professores e colaboradores.

Ao Instituto Agronômico do Paraná (IAPAR), pelo fornecimento dos dados meteorológicos.

Ao Instituto Brasileiro de Geografia e Estatística, Unidades de Maringá e Curitiba, pelos dados de produção agrícola de cana-de-açúcar.

Á Cooperativa Agrícola Regional de Produtores de Cana (Coopcana) de Paraíso do Norte, PR, pelos esclarecimentos e fornecimento de dados de produção agrícola.

Á Cooperativa Agroindustrial (Corol) de Cambé, PR, pelas informações técnicas da cultura da cana-de-açúcar.

Ao Sr. José Adriano da Silva, superintendente da Associação de Produtores de Bioenergia do Estado do Paraná (ALCOPAR) de Maringá, pelas informações e esclarecimentos sobre os dados de produção da cultura da cana-de-açúcar no estado do Paraná.

Ao professor Dr. Nelson Vicente Lovatto Gasparetto, da Universidade Estadual de Maringá, pelo incentivo e sugestões na construção desta tese.

Ao professor Ms. Américo José Marques, da Universidade Estadual de Maringá, pelo apoio nos programas computacionais.

A minha família, que é meu maior patrimônio, pela compreensão, apoio e carinho.

Aos meus amigos, pelo incentivo. 


\section{RESUMO}

Domingues, I. A. S. (2010). Variabilidade climática e sua influência na produtividade da cultura da cana-de-açúcar (Saccharum spp) na região norte e noroeste do Paraná. 2010. 217 f. Tese (Doutorado) - Faculdade de Filosofia, Letras e Ciências Humanas da Universidade de São Paulo, São Paulo.

A atividade agrícola é essencialmente importante para o estado do Paraná, onde a região deste estudo é a porção Norte e Noroeste, representadas pelos municípios de Cambé e Mirador. Regiões estas localizadas sob solos distintos, argilosos e arenosos, respectivamente. Nessas se destacam o cultivo da cana-de-açúcar, objeto deste estudo, por apresentar condições climáticas mais favoráveis ao seu ciclo vegetativo, que tem duração que varia de 12 a 18 meses. Sendo a variabilidade dos controles do clima um fator influenciador principalmente da sua produtividade. Essa cultura exige duas estações meteorológicas bem definidas, uma quente e úmida no estádio de desenvolvimento vegetativo e outra seca ou fria no estádio de maturação. As necessidades térmicas e hídricas são em torno de $20^{\circ}$ a $30^{\circ} \mathrm{C}$ e em torno de 1000 milímetros. Assim, esta tese teve por objetivo determinar a relação entre a variabilidade térmica, hídrica e produtividade do cultivo da cana-de-açúcar para o período de 1981/82 a 2005/06. Os procedimentos metodológicos destinaram-se a evolução espaço-temporal da cana-de-açúcar; à dinâmica climática dos controles chuva e temperatura; à contabilização do Balanço Hídrico (BH Normal, Sequencial e de Cultura) para EXC, DEF, e Extrato do $\mathrm{BH}$; e à correlação dos dados climáticos com a produtividade da cana-de-açúcar. Os dados de chuva e temperatura, período de 30 anos, foram fornecidos pelo IAPAR. Os dados de produção da cana-de-açúcar foram obtidos por meio do PAM/IBGE para um período de 17 anos para todos os municípios paranaenses e por meio dos anuários de produção agrícola do IBGE para um período de 25 anos apenas para os municípios de Cambé e Mirador. Os dados de produtividade foram submetidos à verificação da tendência tecnológica. Os dados de clima foram mensurados por meio das médias aritméticas do período, anual e mensal e juntamente com os dados de produtividade efetuaram-se análises dos desvios em relação à média e análise de correlação e regressão. Por meio desses procedimentos identificou-se que a evolução espaço-temporal da produtividade nos anos de 1990 a 2006, analisada de quatro em quatro anos em escala de mesorregiões, microrregiões e municípios, apresentaram maiores produtividades no ano de 1998 seguido de 2002. As médias das produtividades foram de 82,4 ton/ha em Cambé e de 76,2 ton/ha em Mirador. As médias de chuvas foram de $1604,0 \mathrm{~mm}$ em Cambé e de $1485,0 \mathrm{~mm}$ em Mirador. As temperaturas médias variaram de $21,0^{\circ} \mathrm{C}$ em Cambé e de $22,2^{\circ} \mathrm{C}$ em Mirador. Com a análise dos desvios em relação à média obteve-se para Cambé, que o percentual de anos com desvios coincidentes entre a variável hídrica (chuva e EXC) versus produtividade esteve entre $66,0 \%$ a $76 \%$. E para a DEF versus produtividade o percentual foi de $36,0 \%$ a $44,0 \%$. Em Mirador esses valores ficaram entre $40,0 \%$ a $60,0 \%$ para a variável hídrica e produtividade e entre $28,0 \%$ a $48,0 \%$ para DEF e produtividade. A correlação entre os dados das variáveis analisadas foi significativa ao nível de $5 \%$ e 10\% para: chuva e produtividade; DEF no estádio de maturação (BH Sequencial) e produtividade; EXC e DEF no estádio de desenvolvimento ( $\mathrm{BH}$ de Cultura); temperatura na série temporal estudada em anos de La Niña e em anos ENOS (BH Cultura) em Cambé; em Mirador a correlação significativa para EXC do BH 
Sequencial Decendial para o período de vinte e cinco anos e para DEF do $\mathrm{BH}$ Cultura em anos de La Niña no estádio de desenvolvimento. A temperatura apresentou correlação significativa na série temporal (BH Cultura) no estádio de Estabelecimento e para anos ENOS (BH de Cultura) nos estádio de Estabelecimento em EL Niño e desenvolvimento em La Niña. Assim, anos com chuva acima da média (El Niño) e anos com chuva na média do período (Neutro), apresentam correlação pouco significativa com a produtividade da cana-de-açúcar que em anos com chuva abaixo da média (La Niña).

Palavras-chave: variabilidade climática, precipitação pluvial, temperatura do ar, saccharum spp, produtividade. 


\section{ABSTRACT}

Domingues, I.A. S. (2010). Climatic variability and its influence on the productivity of the sugarcane culture (Saccharum spp) in the north and northwest region of Paraná State (Brazil). 2010. 217 f. Tese (Doutorado) - Faculdade de Filosofia, Letras e Ciências Humanas da Universidade de São Paulo, São Paulo.

Agricultural activity is essentially very important to the state of Paraná. The study area of this work is located in the north and northwest region (municipalities Cambé and Mirador, respectively). The former has basalt soil and the latter has Caiuá sandstone soil. The cultivation of sugarcane, the object of this study, predominates due to climatic conditions that are favorable to its vegetative cycle, which varies from 12 to 18 months. The variability of the climate controls is an influential factor on productivity. The culture requires two well-defined meteorological seasons: one hot and humid in the state of vegetative development and the other dry or cold in the state of maturation. The temperature and water requirements are about $20^{\circ} \mathrm{C}$ to $30^{\circ}$ $\mathrm{C}$ and about 1000 millimeters. This work had as its objective the determination of the relationship between the temperature and water variability and the productivity of the sugarcane cultivation from $1981 / 82$ to $2005 / 06$. The methodological procedures addressed spatio-temporal evolution of the sugarcane; the climatic dynamics of the controls rain and temperature; calculation of the water balance - WB (Normal, Sequential and Cultural WB) for EXC (water excess), DEF (water deficit) and WB Extract; and the correlation of the climatic data with the productivity of the sugarcane. The rain and temperature data were supplied by IAPAR (30-year period). The sugarcane production data (area, production and productivity) were obtained from PAM/IBGE (17-year period) for all municipalities of Paraná and from yearbooks of agricultural production from IBGE (25-year period) for only the municipalities of Cambé and Mirador. The productivity data were submitted to verification of the technological tendency. The climate data were measured using period, annual and monthly arithmetic means. Together with the productivity data, analyses of the deviations in relation to the mean and analysis of correlation and regression were carried out. Through these procedures, the spatio-temporal evolution of the productivity from 1990 to 2006, analyzed every four years on a scale of mesoregions, microregions and municipalities, presented the highest productivity in 1998, followed by 2002 . The productivity means were 82.4 ton/ha in Cambé and 76.2 ton/ha in Mirador. The rain means were $1604.0 \mathrm{~mm}$ in Cambé and $1485.0 \mathrm{~mm}$ in Mirador. The mean temperatures varied from $21.0^{\circ} \mathrm{C}$ in Cambé and $22.2^{\circ} \mathrm{C}$ in Mirador. Based on the analysis of the deviations in relation to the mean, in Cambé, the percentage of years with coincident deviations between the water variable (rain and EXC) and productivity was $66.0 \%$ to $76.0 \%$. It was $36.0 \%$ to $44.0 \%$ between DEF and productivity. In Mirador these values were between $40.0 \%$ and $60.0 \%$ for the water variable and productivity and between $28.0 \%$ and $48.0 \%$ for DEF and productivity. The correlation between the data of all the analyzed variables was significant to $5 \%$ and $10 \%$ for: rain versus productivity; DEF in the maturation stage (Sequential WB) and productivity; EXC and DEF in the development stage (Cultural WB); temperature in the temporal series studied in La Niña years and in ENOS years (Cultural WB) in Cambé; significant correlation for EXC of the water balance for sequential ten-day 
periods for twenty-five years and for DEF of the Cultural WB in La Niña years in the development stage in Mirador. The temperature variable presented significant correlation in the temporal series studied for Cultural WB in the vegetative development stage for twenty-five years for El Niño and La Niña. Thus, years with rainfall above the mean (El Niño) and years with a mean rainfall (Neutral) presented insignificant correlation with the sugarcane productivity compared to years with rainfall below the mean (La Niña).

Key words: climatic variability, pluvial precipitation, air temperature, saccharum spp, productivity. 


\section{LISTA DE FIGURAS}

Figura 1- Probabilidade de ocorrência de geadas em junho (A), Julho 36 (B) e agosto (C) no Paraná.

Figura 2- Regiões com aptidão térmica ao cultivo da cana-de-açúcar no Paraná.

Figura 3- $\quad$ Acúmulo de graus-dias (응 da cana-de-açúcar..................... 42

Figura 4- Índice de Área Foliar de cana-planta da variedade 45 RB855113, cultivada na região de Paranavaí, PR.

Figura 5- Ciclo da Cultura da cana-de-açúcar para a região CentroSul do Brasil.

Figura 6- Exemplo ilustrativo de estágios de corte e valores médio de produtividade da cana-de-açúcar.

Figura 7- Fases de desenvolvimento da cultura da cana-de- 55 açúcar...

Figura 8- $\quad$ Partes de uma planta de cana-de-açúcar em crescimento subaéreo e aéreo.

Figura 9- $\quad$ Fluxograma de orientação metodológica norteador do 59 desenvolver da tese.

Figura 10- Mapa de localização do estado do Paraná destacando os municípios de Mirador a Noroeste e Cambé no Norte Central.

Figura 11- Divisão do estado do Paraná em: (A) 10 Mesorregiões e (B) 62 39 Microrregiões.

Figura 12- Mapa geológico do Paraná ilustrando perfil geológico.............

Figura 13- Perfil geológico-geomorfológico do estado do Paraná 65 ilustrando as cinco grandes paisagens naturais.

Figura 14- Sedimentação e magmatísmo no Mesozóico........................... 68

Figura 15- Mapa do Paraná ilustrando as áreas estudadas subdivididas 69 de acordo com o IBGE: Mesorregiões geográficas, Microrregiões e Municípios. Em destaque os municípios nas mesorregiões Norte Central e Noroeste.

Figura 16- Classificação climática do Paraná efetuada pelo IAPAR com 73 base na classificação climática de Köppen.. 
Figura 17- Tipos de climas do estado do Paraná, segundo critérios de Köppen.

Figura 18- Temperatura do ar (A) e Precipitação média anual (B) e 75 pluviometria do trimestre mais seco (C) do estado do Paraná da série histórica de 1972 a 1998.

Figura 19- Temperaturas médias das mínimas para o trimestre mais 77 frio no estado do Paraná.

Figura 20- Tipologia pedológica da área estudada. 78

Figura 21- Toposseqüência esquemática de tipos de solos originados de rochas Basalto e Arenito Caiuá. LV- Latossolo Vermelho; NV- Nitossolo; AG- Argissolo; NQ- Neossolo Quartzarênico; G-Gleissolo

Figura 22- Distribuição do estado atual das florestas do Paraná por mesorregiões geográficas paranaense

Figura 23- Dados da cultura da cana-de-açúcar no Brasil e regiões, - 99 $\mathrm{A}=$ Área plantada, $\mathrm{B}=$ Produção e $\mathrm{C}=$ Produtividade, período de 1990 a 2006.

Figura 24- Área plantada com a cultura da cana por mesorregião 104 paranaense no período de 1990 a 2006

Figura 25- Produtividade média anual da cana nas mesorregiões 108 paranaense no período de 1990 a 2006

Figura 26- $\quad$ Produção anual da cana para as mesorregiões paranaense 110 no período de 1990 a 2006

Figura 27- Variação interanual da produtividade original (sem correção) e sem tendência tecnológica (corrigida) da cana-de-açúcar nos municípios de Cambé (A) e Mirador (B), período 1982 a 2006.

Figura 28- Área plantada (A), produção (B) e produtividade (C) da 128 cana-de-açúcar nos municípios de Mirador e Cambé, PR, no período de 1990 a 2006

Figura 29- Valores médios de produtividade em diferentes escalas regionais para o período estudado: Mesorregiões Paranaense; Microrregiões com rendimento acima 79 ton/ha; municípios com valores de 85 ton/ha e; dois municípios em solos distintos com os melhores rendimentos.

Figura 30- Área plantada com cana-de-açúcar nas mesorregiões 132 paranaense, para os anos de 1990, 1994, 1998, 2000, 
2002,2005 e 2006

Figura 31- Produção de cana-de-açúcar nas mesorregiões paranaense 133 para os anos de 1990, 1994, 1998, 2002, 2005 e 2006.

Figura 32- Produtividade da cana-de-açúcar nas mesorregiões 136 paranaense, para os anos de 1990, 1994, 1998, 2000, 2002, 2005 e 2006.

Figura 33- Área plantada com cana-de-açúcar nas microrregiões paranaense, para os anos de 1990, 1994, 1998, 2000, 2002, 2005 e 2006.

Figura 34- Produção da cultura da cana-de-açúcar nas microrregiões paranaense, para os anos de 1990, 1994, 1998, 2000, 2002, 2005 e 2006.

Figura 35- Produtividade da cana-de-açúcar nas microrregiões 142 paranaense, para os anos de 1990, 1994, 1998, 2000, 2002, 2005 e 2006.

Figura 36 Área plantada com cana-de-açúcar nos principais 145 municípios produtores do Paraná, período 1990, 1994, 1998, 2000, 2002, 2005 e 2006.

Figura 37- Produção da cana-de-açúcar nos principais municípios 146 produtores do Paraná, período 1990, 1994, 1998, 2000, 2002, 2005 e 2006.

Figura 38- Produtividade da cana-de-açúcar nos principais municípios produtores do Paraná, anos de 1990, 1994, 1998, 2000, 2002, 2005 e 2006.

Figura 39- Precipitação pluvial total anual em Cambe (A) e em Mirador (B) e precipitação pluviométrica mensal em Cambé (C) e em Mirador (D), para o período de 1976 a 2006

Figura 40- Número de dias com chuva anual em Cambé $(A)$ e em Mirador (B), e mensal em Cambé (C) e em Mirador (D), período de 1976 a 2006.

Figura 41- Dias com chuva acima de $50 \mathrm{~mm}(\mathrm{~A})$, média do percentual dos meses com chuvas acima de $50 \mathrm{~mm}$ em relação ao total de chuva mensal (B) e percentual das chuvas acima de $50 \mathrm{~mm}$ em relação ao total de chuva anual (C), período de 1981 a 2006.

Figura 42- Temperatura média anual (A, B) e mensal (C, D) do período 160 de 1976 a 2006 dos municípios de Cambé e Mirador.

Figura 43- $\quad$ Média do número de dias mensal do período (1976 a 2006) 161 com temperatura abaixo de $16^{\circ} \mathrm{C}$ para os municípios de 
Cambé e Mirador, PR

Figura 44- Número de dias por ano do período (1976 a 2006) com temperatura abaixo de 16으 C para os municípios de Cambé e Mirador, PR.

Figura 45- Desvios de chuva e produtividade (A) e desvio de temperatura e produtividade (B), município de Cambé, anos agrícolas $1981 / 82$ a $2005 / 06$

Figura 46- Desvios de chuva e produtividade (A) e desvio de 166 temperatura e produtividade (B), município de Mirador, ano agrícolas 1981/82 a 2005/06

Figura 47- Dispersão dos desvios de chuva com a produtividade da cana-de-açúcar (A) e de temperatura com a produtividade (B) do município de Cambé, anos agrícolas 1981/82 a 2005/06.

Figura 48- Dispersão dos desvios de chuva e produtividade da canade-açúcar (A) e de temperatura com a produtividade (B), do município de Mirador, anos agrícolas 1981/82 a 2005/06......

Figura 49- Desvios de EXC e DEF com os desvios de produtividade da cana-de-açúcar nos municípios de Cambé (A e B) e Mirador (C e D), PR, para o período de 1981/82 a 2005/06.

Figura 50- Dispersão dos desvios de EXC e DEF com os desvios de Produtividade da cultura da cana-de-açúcar nos municípios de Cambé (A e B) e Mirador (C e D), PR para o período de $1981 / 82$ a 2005/06.

Figura 51- Desvios de EXC e DEF com desvios de Produtividade da 177 cana-de-açúcar de Cambé e Mirador, PR, período de $1981 / 82$ a $2005 / 06$

Figura 52- Coeficiente de correlação das variáveis EXC e DEF com a 178 produtividade da cana-de-açúcar nos estádios de desenvolvimento e maturação nos municípios de (A) Cambé e (B) Mirador, período de1981/82 a 2005/06.

Figura 53- Diagrama de dispersão das variáveis hídricas e a 179 produtividade da cana-de-açúcar para os municípios de Cambé e Mirador, período 1981/82 a 2005/06.

Figura 54- Desvios de EXC/DEF e Produtividade da cultura da canade-açúcar nos municípios de Cambé e Mirador, anos agrícolas 1981/82 a 2005/06

Figura 55- Dispersão entre EXC/DEF e Produtividade para a cultura da 183 cana-de-açúcar nos municípios de Cambé $\left(A_{1}\right.$ e $\left.A_{2}\right)$ e 
Mirador $\left(B_{1}\right.$ e $\left.B_{2}\right)$, anos agrícolas de $1981 / 82$ a $2005 / 206 \ldots . .$.

Figura 56- Extrato do BH Sequencial dos anos agrícolas com desvios 185 máximos de EXC e DEF hídrica e suas respectivas Produtividades para Cambé (máx. EXC: $A_{1}, A_{2}$, máx. DEF: $B_{1}$ e $B_{2}$ ) e Mirador (Máx. EXC: $C_{1}, C_{2}$, máx. DEF: $D_{1}$ e $D_{2}$ ), PR.

Figura 57- Desvios de EXC, DEF e Produtividade da cana-de-açúcar 190 nos municípios de Cambé e Mirador, anos agrícolas 1981/82 a 2004/05.

Figura 58- Dispersão entre EXC/DEF e Produtividade da cana-deaçúcar nos municípios de Cambé e Mirador, anos agrícolas $1981 / 82$ a $2005 / 06$

Figura 59- Desvios de EXC/DEF por fase fenológica com a 196 Produtividade da cultura da cana-de-açúcar para 0 município de Cambé, período de 1981/82 a 2005/06

Figura 60- Desvios de EXC/DEF por fase fenológica com a 197 Produtividade da cultura da cana-de-açúcar para 0 município de Mirador, período de 1981/82 a 2005/06.

Figura 61- Diagrama de dispersão das variáveis EXC/DEF com a Produtividade da cana-de-açúcar em Cambé, anos agrícolas 1981/82 a 2005/06

Figura 62- Correlação e dispersão das variáveis EXC/DEF com a 200 Produtividade da cana-de-açúcar em Mirador, anos agrícolas 1981/82 a 2005/06

Figura 63- Extrato do $\mathrm{BH}$ de Cultura dos anos agrícolas com maiores totais de EXC e DEF hídrica e suas respectivas Produtividades do município de Cambé.

Figura 64- Extrato do BH de Cultura dos anos agrícolas com desvios 206 máximos de EXC e DEF hídrica e suas respectivas Produtividades dos municípios de Mirador.

Figura 65- Correlação da temperatura média anual com a 210 produtividade da cana-de-açúcar nos municípios de Cambé e Mirador, anos agrícolas de 1982/83 a 2005/06

Figura 66- Desvio de temperatura média anual e de produtividade da 210 cana-de-açúcar para os municípios de Cambé e Mirador, período de 1981/82 a 2005/2006.

Figura 67- Desvios de Temperatura por estádio fenológico e de 213 produtividade nos municípios de Cambé e Mirador, anos agrícolas de 1981/82 a 2005/06. 
Figura 68- Correlação e dispersão por estádio fenológico entre 215 temperatura e produtividade dos municípios de Cambé e Mirador, anos agrícolas de 1981/82 a 2005/06...................... 


\section{LISTA DE TABELAS}

Tabela 1- Características de plantas $\mathrm{C}_{4}$ (gramíneas tropicais).............. 48

Tabela 2- Aptidão climática para a cana-de-açúcar para o território 49 brasileiro (CAMARGO et al., 1977)

Tabela 3- Cronograma de distribuição mensal de plantio/rebrota e 51 colheita da cana-de-açúcar no estado do Paraná (SEAB, 2008) e das microrregiões de Londrina e Paranavaí.

Tabela 4- Período de duração para cada fase de desenvolvimento da cultura da cana-de-açúcar, Coeficiente de cultura $(\mathrm{Kc})$ e Índice de Área Foliar.

Tabela 5 Evolução temporal da cobertura vegetal no estado do Paraná (Padilha Junior, 2004)

Tabela 6- Valores de Kc para cana-planta e cana soca

Tabela 7- Dados anuais de Produtividade; dados do período de 102 Produção e área plantada com cana-de-açúcar, 1990 a 2006 no território brasileiro

Tabela 8- Produtividade média e área plantada da cultura da cana-de- 106 açúcar por Mesorregião Geográfica paranaense, de 1990 a 2006

Tabela 9- Dados médios da área plantada e da produção e produtividade de cana-de-açúcar para o período de 19902006 por mesorregião no estado do Paraná

Tabela 10- Relação das dezoito microrregiões paranaense e número de municípios produtores e não produtores de cana-de-açúcar no período de 1990 a 2006

Tabela 11- Área Plantada, Produção e Produtividade da cultura de cana-de-açúcar para as dezoito microrregiões paranaense pertencentes às mesorregiões Noroeste, Norte (Central e Pioneiro) e Centro-Ocidental, período de 1990 a 2006.

Tabela 12- Valores médios de área plantada, produção e produtividade da cana-de-açúcar para dezoito microrregiões paranaense, período 1990 a 2006

Tabela 13- Valores médios da produtividade, área plantada e produção da cana-de-açúcar para os municípios com rendimentos em torno de 85 ton/ha, 1990 a 2006. Localização em ordem de 
mesorregião, microrregião e município

Tabela 14- Valores médios de área plantada, de produção e de produtividade da cana, para o período de 1990 a 2006 nos municípios com produtividade em torno de 80 ton/ha.

Tabela 15- Dados originais (sem correção) de produtividade da canade-açúcar e nova série de dados de produtividade (corrigidos) dos municípios de Cambé e Mirador, PR, no período de 1982 a 2006.

Tabela 16- Dados de área plantada, produção, produtividade e desvio de produtividade da cana-de-açúcar para os municípios de Mirador e Cambé, PR.

Tabela 17- Ocorrência de chuvas acima de $50 \mathrm{~mm}$ para o período de 1981 a 2006 em Cambé PR.

Tabela 18- Precipitação pluviométrica acima de $50 \mathrm{~mm}$ para o período de 1990 a 2006 em Mirador.

Tabela 19- Dados de chuva anual, temperatura média anual e produtividade e seus desvios em relação à média $\left(\mathrm{d}_{\mathrm{i}}\right) \mathrm{e}$ coeficiente de correlação (r) no período de 1990 a 2006 para os municípios de Mirador e Cambé.

Tabela 20- Dados de EXC, DEF, produtividade, seus desvios $\left(d_{i}\right)$ em relação à média e coeficiente de correlação $(r)$ dos anos agrícolas de 1981/82 a 2005/06 para Cambé e Mirador

Tabela 21- Dados de EXC e DEF por estádios de desenvolvimento e maturação, dados de produtividade seus desvios e coeficientes de correlação em Cambé e Mirador, anos agrícolas 1981/82 a 2005/06

Tabela 22- Dados de EXC e DEF, Produtividade, seus desvios em relação à média $\left(\mathrm{d}_{\mathrm{i}}\right)$ e coeficientes de correlação para os anos agrícolas de 1981/82 a 2005/06 dos municípios de Cambé e Mirador, PR.

Tabela 23- Dados anuais de EXC e DEF do BH de Cultura, dados de Produtividade, seus desvios e coeficientes de correlações para os anos agrícolas de 1981/82 a 2005/06 em Cambé e Mirador, PR

Tabela 24- Dados anuais por fases fenológicas das variáveis de EXC, 193 DEF e produtividade, seus desvios e correlações, municípios de Cambé e Mirador, anos agrícolas 1981/82 a 2005/06 
Tabela 25- Dados de temperatura, produtividade, duração do ciclo da 209 cultura da cana-de-açúcar por decêndio e seus desvios em relação à média nos municípios de Cambé e Mirador, anos agrícolas 1981/82 a 2005/06.

Tabela 26- Dados de temperatura por estádio fenológico (Estabilidade, 212 Desenvolvimento Vegetativo e Maturação) e de produtividade da cana-de-açúcar, seus desvios em relação à média e correlação, para Cambé e Mirador, PR, anos agrícolas 1981/82 a 2005/06

Tabela 27- Correlação $(r)$ e teste $t$ Student entre temperatura, chuva e produtividade para período de 25 anos e por $\mathrm{BH}$ Normal e Sequêncial por estádios fenológicos (EXC e DEF) e esses por anos de ENOS, série de anos 1981/82 a 2005/06, municípios de Cambé e Mirador, PR.

Tabela 28- Correlação $(r)$ e teste $t$ Student entre EXC e DEF (BH de Cultura) para o período de 25 anos por estádios fenológicos e em anos de ENOS por estádios fenológicos, série de anos de 1981/82 a 2005/06, municípios de Cambé e Mirador, PR.

Tabela 29- Correlação $(r)$ e teste $t$ Student entre temperatura e produtividade, para estádios fenológicos (BH Cultura) do período de 25 anos e por anos de ENOS, série de anos de 1981/82 a 2005/06 nos municípios de Cambé e Mirador, PR. 


\title{
LISTA DE SIGLAS
}

\author{
ALCOPAR - $\quad$ Associação de produtores de bioenergia do Paraná \\ COOPERSUCAR - Cooperativa de produtores de cana-de-açúcar e álcool \\ do estado de São Paulo \\ CONAB - $\quad$ Companhia Nacional de Abastecimento \\ ENOS - $\quad$ El Niño Oscilação Sul \\ IAPAR - $\quad$ Instituto Agronômico do Paraná \\ IBGE - Instituto Brasileiro de Geografia e Estatística \\ IPARDES - $\quad$ Instituto Paranaense de Desenvolvimento Econômico e \\ Social \\ MINEROPAR - $\quad$ Minerais do Paraná \\ PLANALSUCAR - Programa Nacional de Melhoramento da Cana-de- \\ açúcar \\ RIDESA - $\quad$ Rede Interuniversitária para o Desenvolvimento do Setor \\ Sucroalcooleiro \\ UNICA - $\quad$ União da Indústria de Cana-de-açúcar
}




\section{SUMÁRIO}

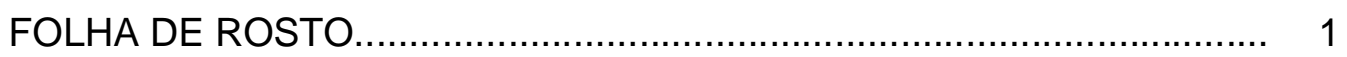

VERSO DA FOLHA DE ROSTO........................................................... 1

FOLHA DE APROVAÇÃO............................................................... 2

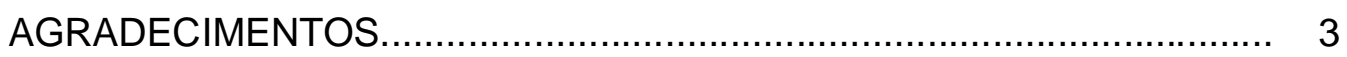

RESUMO

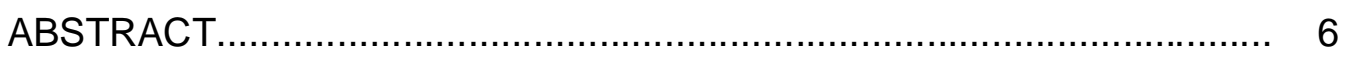

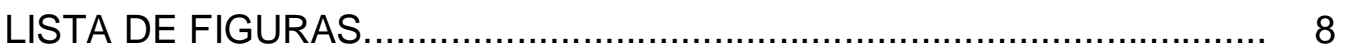

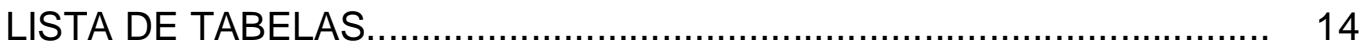

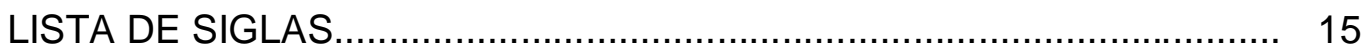

SUMÁRIO

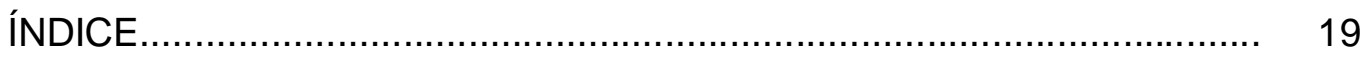

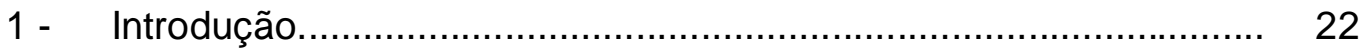

2 - Revisão Bibliográfica................................................................ 26

3 - Materiais e Métodos.................................................................. 59

4 - Resultados e Discussões ....................................................... 98

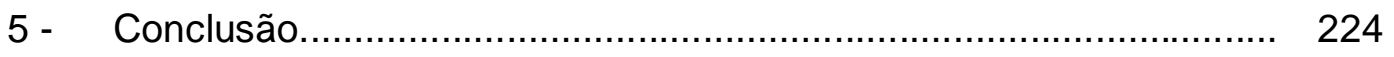

6 - Referências...................................................................... 226 


\section{ÍNDICE}

INTRODUÇÃO.................................................................. 22

1.1 -

Hipótese..

2.2.1 El Niño Oscilação Sul (ENOS) e sua influência na produtividade agrícola...... açúcar. Condições radioativas e sua relação com a cultura da cana-deaçúcar.

Procedimento metodológico para a evolução espaço-temporal da cultura da cana-de-açúcar na região estudada......

3.3.4 - Procedimento metodológico para determinar tendência tecnológica Procedimento metodológico para a análise da pluviometria e da 86 temperatura. na produtividade da cana-de-açúcar 
3.3.7 - Procedimento metodológico para obtenção de anos de El Niño 96

4 RESULTADOS E DISCUSSÕES.

4.1 - Quantificação da cultura da cana-de-açúcar no território nacional e no estado do Paraná no período de 1990 a 2006

4.2 - Distribuição espacial da cultura da cana-de-açúcar no estado do Paraná e sua evolução temporal no período de 1990 a 2006

Análise da cultura da cana-de-açúcar por microrregiões e municípios......

Tendência tecnológica na produtividade da cana-de-açúcar nos municípios de Cambé e Mirador.

4.4 - $\quad$ Análise dos dados de área plantada, produção e produtividade da cana-de-açúcar dos municípios de Mirador e Cambé, PR .

4.5 - Mapeamento da evolução espaço-temporal das variáveis de produção da cultura cana-de-açúcar em escalas de mesorregiões, microrregiões e municípios.

4.5.1 - Mapeamento por mesorregiões das variáveis área plantada, produção e produtividade

Mapeamento por Microrregiões das variáveis área plantada, produção e produtividade.

4.5 .3 - Mapeamento da evolução espaço-temporal da cana-de-açúcar por municípios das variáveis área plantada, produção e produtividade......

\section{6 -}

Variabilidade termopluviométrica a nível local.

Pluviometria. da cultura da cana-de-açúcar nos municípios de Cambé e Mirador, PR.

4.7.1 - Correlação dos dados de chuva e temperatura com os dados de produtividade da cana-de-açúcar.....

4.7.2 - Balanço Hídrico Normal e a produtividade da cultura da cana-deaçúcar.....

4.7.2.1 - Correlação dos dados de EXC e DEF (BH Normal) com os de produtividade da cana-de-açúcar.....

4.7.2.2 - Quantificação das variáveis EXC e DEF para os estádios de desenvolvimento vegetativo e maturação ....

4.7.3 - Balanço Hídrico Sequencial e a produtividade da cana-de-açúcar......

4.7.3.1 - $\quad$ Análise do extrato do BH Sequencial para as variáveis EXC e DEF.... acúcar.

4.7.4.1 - $\quad$ Análise de desvio em relação à média para as variáveis EXC, DEF e Produtividade nos municípios de Cambé e Mirador...

4.7.4.2 - Análise de desvio em relação à média das variáveis EXC, DEF e Produtividade nos municípios de Cambé e Mirador.....

de correlação entre as variáveis hídricas e 190 
4.7.4.4 - Análise das variáveis hídricas por estádio fenológico versus 191 produtividade.

4.7.4.5 - $\quad$ Análise dos desvios de EXC/DEF versus Produtividade...................... 195

4.7.4.6 - Correlação entre as variáveis EXC/DEF versus Produtividade.... 198

4.7.4.7 Análise do extrato do BH de Cultura versus Produtividade......... 201

4.7.5 - $\quad$ Análise da variabilidade térmica e a produtividade da cultura da 208

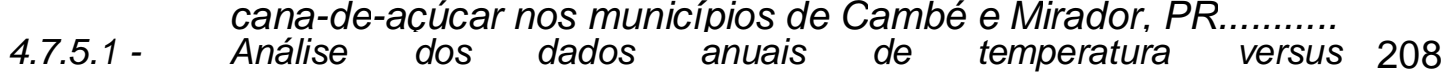
produtividade...

4.7.5.1.1 - $\quad$ Quanto à temperatura do ar e a duração do ciclo da cultura................ 208

4.7.5.1.2 - Quanto à correlação e desvio entre a temperatura média anual e a 209 produtividade.

4.7.5.2 - Análise por estádio fenológico da variável temperatura versus 211 produtividade.

4.7.5.3 - $\quad$ Análise de Correlação das variáveis temperatura e produtividade por 214 estádio fenológico.

4.7.6 - Análise de correlação das variáveis chuva, temperatura, EXC, 215 DEF e produtividade por episódios ENOS.

4.7.7 - $\quad$ Tipos de solos e a produtividade da cultura da cana-de-açúcar... 222

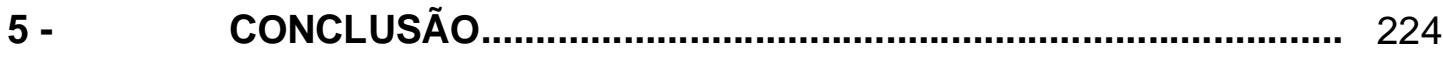

6 - REFERÊNCIAS BIBLIOGRÁFICAS..................................... 226 


\section{1- INTRODUÇÃO}

O estudo da variabilidade climática e de sua influência na agricultura vem sendo a cada dia mais valorizado, com vistas à obtenção de mais e melhores conhecimentos científicos e tecnológicos necessários a uma produção agrária sustentável. Ou seja, cresce a convicção de que é preciso entender e priorizar as condições climáticas, para que se possa produzir cada vez mais em área agricultável cada vez mais reduzida.

Isso porque, ao se objetivar uma produtividade compensadora, deve-se levar em conta que cada cultura necessita de condições favoráveis durante todo o seu ciclo vegetativo, exigindo determinados limites de temperatura nos vários estádios do ciclo, uma quantidade mínima de água e um período seco no estádio de maturação e colheita (PEREIRA, 2002).

Para alcançar essas metas, uma das primeiras exigências é o conhecimento sistematizado das condições climáticas (juntamente com os fenômenos que as influenciam, como é o caso do El Niño, que pode alterar o padrão geral da circulação atmosférica) e agroclimatológicas.

Esse conhecimento deve ser cada vez mais aplicado em economias que visam a um futuro promissor para a maioria das culturas, sejam elas comerciais ou de subsistência, embora as primeiras, com abrangência em macroescala, ganhem prioridade quando se trata de pesquisa científica.

Dentre as culturas mais cultivadas na atualidade, e em grande expansão em área e em produtividade, tem-se a cana-de-açúcar, objeto deste estudo. Essa cultura tem dupla finalidade, destinando-se tanto à alimentação humana (por exemplo, o açúcar) e pecuária (ração animal) quanto à geração de energia (etanol, dentre outros).

O Brasil situa-se como o maior produtor e exportador de cana-de-açúcar (645.300.182ton em 2008), seguido pela Índia. Nacionalmente, o Paraná, com área plantada no ano agrícola de 2007/2008 em torno de 500 mil hectares, é o segundo maior produtor $(7,8 \%$ da produção brasileira), antecedido por São Paulo. Nas 
regiões Norte e Noroeste do Paraná, a cultura da cana-de-açúcar ocupou em 2006 uma área de 394.189 hectares (IBGE, 2007).

Como a área plantada está em constante expansão, com aumento em média, para os últimos 17 anos (1990 a 2006), de aproximadamente 67,0\%, faz-se necessário um conhecimento mais detalhado das condições climáticas, que, nas diversas regiões, exercem influência em cada estádio de desenvolvimento da cultura e consequentemente no seu rendimento.

Com o propósito de oferecer uma contribuição nesse sentido, o presente trabalho de pesquisa trata das condições climáticas que influenciam a produtividade do cultivo da cana-de-açúcar (Saccharum spp) no estado do Paraná.

Como se sabe, os tipos climáticos, juntamente com os controles geográficos, determinam o desenvolvimento das espécies vegetais ou das culturas agrícolas, principalmente no que diz respeito ao seu rendimento (DOORENBOS, KASSAN, 1994).

O cultivo da cana-de-açúcar no estado do Paraná foi escolhido como tema desta pesquisa em razão de sua importância na atual conjuntura econômicoambiental, não só do Brasil, mas também em âmbito mundial. Isso se evidencia na medida em que cresce a preocupação com a questão da variabilidade dos atributos do clima como fator extremamente significativo para a produtividade dessa cultura.

\section{1 - Hipótese}

A cana-de-açúcar é uma cultura exigente quanto às condições climáticas, no que diz respeito principalmente à disponibilidade térmica e hídrica. Grande parte do estado do Paraná $\left(134.543,89 \mathrm{~km}^{2}\right)$ situa-se em latitudes maiores que $24^{\circ} \mathrm{S}$, motivo pelo qual apenas uma restrita área do estado $\left(64.771,05 \mathrm{~km}^{2}\right)$ oferece condições favoráveis ao desenvolvimento dessa cultura. De modo geral, tem-se que esses fatores, aliados às condições de variabilidade dos atributos e controles climáticos sobre tal cultura, resultam em uma produtividade heterogênea. 
A hipótese levantada por este trabalho é a de que, principalmente nas regiões Norte e Noroeste do Paraná, a variabilidade da temperatura do ar, da pluviometria e da água armazenada no solo define a produtividade da cana-de-açúcar.

\section{2 - Justificativa}

O conhecimento detalhado do clima e de sua influência em determinada cultura possibilita maior rendimento e menor custo, favorecendo o desenvolvimento do agronegócio em países que, como o Brasil, apresentam grande diversidade climática.

O estado do Paraná situa-se em área de transição climática, ou seja, de clima tropical para subtropical, necessitando, porém, de conhecimento detalhado das condições de variabilidade climática. Tal conhecimento é fundamental para o bom desenvolvimento da agricultura e da agroindústria, principalmente no que diz respeito ao cultivo da cana-de-açúcar, que se encontra em processo de expansão.

A necessidade de se pesquisar a cultura da cana-de-açúcar passa pelo fato de esta originar vários subprodutos de grande importância para a humanidade. Sobretudo por se destinar ao consumo humano (açúcar e derivados) e pecuário (ração animal), além de constituir fonte de energia renovável e menos poluente que o petróleo (etanol e similares).

Todavia, embora proporcione tantos benefícios, a cultura da cana-de-açúcar no Brasil, até o momento, ocupa uma área plantada em torno de apenas 6 milhões de hectares, quando tem disponíveis para o seu plantio 28 milhões de hectares (RODRIGUES, 2007). No Paraná, a área plantada em 2006 era de 432,815 hectares, isto é, $7,2 \%$ da área plantada no Brasil. Esse é um motivo a mais para se buscar informações ambientais mais sistematizadas sobre tal cultura na área de estudo. 


\section{3 - Objetivos}

A pesquisa buscou definir a relação entre a variabilidade térmica e hídrica e a produtividade do cultivo da cana-de-açúcar nas regiões Norte e Noroeste do Paraná, período $1981 / 82$ a 2005/06.

\subsection{1 - Objetivos específicos}

- Caracterizar e analisar a variabilidade das condições térmicas e pluviométricas da região estudada;

- Mensurar o balanço hídrico climatológico da área, bem como da cultura da canade-açúcar, para cada um de seus estádios fenológicos;

- Relacionar a produtividade da cultura da cana-de-açúcar em razão da variabilidade dos elementos do balanço hídrico;

- Identificar a correlação entre as variáveis chuva e temperatura e a produtividade em anos de ocorrência de El Niño Oscilação Sul - ENOS (anos de El Niño, anos de La Niña e anos Neutros). 


\section{2 - REVISÃO BIBLIOGRÁFICA}

A revisão bibliográfica, fundamental na estrutura do trabalho de pesquisa, tem como objetivo imediato o conhecimento necessário para a compreensão dos temas estudados. É um suporte indispensável à explicação dos resultados experimentais obtidos e à sua discussão.

Neste item, sistematizam-se informações inerentes à temática abordada, com foco na variabilidade climática, na influência exercida por essa variabilidade sobre a produtividade da cana-de-açúcar e nas características climáticas e fisiológicas dessa cultura.

\section{1 - Histórico da cana-de-açúcar e principais cultivares/variedades}

Uma breve descrição histórica da cana-de-açúcar se faz necessária antes de abordar os itens propostos.

Segundo Castro et al. (2001), a cana-de-açúcar (Saccharum spp) pertence à classe monocotiledônea e à família Gramínea. É uma planta alógama, ou seja, fecundada pela união de gametas de indivíduos diferentes.

De origem provavelmente asiática, a cana-de-açúcar foi cultivada cerca de 10.000 anos a.C. em Papua Nova Guiné, expandindo-se na Polinésia. Por volta de 1.000 anos a.C. teve sua expansão na Península Malaia, Indochina e Baía de Bengala. No início do ano 640 d.C. atingiu o Mediterrâneo e no século IX teve-se a primeira descrição do processo da cultura e fabricação do açúcar na Índia (UNICA, 2008).

Os portugueses e espanhóis levaram a cana para implantação nas suas colônias, fazendo com que Portugal fosse por um bom tempo, do período colonial, o maior produtor mundial de açúcar. Em território nacional, essa cultura chegou por volta de 1532. Foi introduzida por Martin Afonso de Souza, que fundou o primeiro engenho de açúcar brasileiro (denominado São Jorge dos Erasmos) na capitania de São Vicente, hoje Baixada Santista, litoral de São Paulo, ali implantando as variedades creola e caiana. Três anos depois, em 1535, Jerônimo de Albuquerque 
implantou o primeiro engenho de açúcar no Nordeste, nas proximidades de Olinda, Pernambuco (ÚNICA, 2008).

Dentre as 30 espécies conhecidas, a principal a ser cultivada inicialmente foi a Saccharum officinarum $\mathrm{L}$. ( $\mathrm{L}=$ primeiro nome do autor), entretanto as cultivares dessa espécie passaram a sofrer dificuldades de adaptação ecológica e severos danos provocados por doenças.

Por meio de melhoramento genético, foram criados híbridos interespecíficos (transferência de genes de um genótipo resistente para um suscetível), resistentes e melhor adaptados às diversas condições ambientais, o que permitiu a expansão da cultura (FIGUEIREDO et al., 1995; MATSUOKA et al., 1999).

Em se tratando de melhoramento genético, procurou-se distinguir e conceituar cultivares e híbridos. Por cultivares entendem-se espécies de plantas que foram melhoradas devido às alterações ou introduções de uma característica nova, ou seja, um subtipo dentro de uma espécie de planta com características específicas. E por híbrido conceitua-se o produto do cruzamento entre espécies diferentes, ou, ainda, entre linhagens geneticamente diferentes.

Algumas das espécies (do gênero Saccharum) de cana-de-açúcar são classificadas da seguinte maneira (CASTRO et al., 2001; MATSUOKA et al., 1999):

S. officinarum L. apresenta características especiais, como colmos suculentos, com bom teor de sacarose, boa pureza do caldo e teor de fibra adequado para moagem. Produz entre 60 ton $/ \mathrm{ha}^{-1}$ e 120 ton $/ \mathrm{ha}^{-1}$ de colmos, com comprimento e diâmetro médios de $171 \mathrm{~cm}$ a $217 \mathrm{~cm}$ e $19,1 \mathrm{~mm}$ a $22,2 \mathrm{~mm}$, respectivamente, em plantios de sequeiro, com a vantagem de não haver necessidade de replantio por 4 a 5 anos. São exigentes em clima e solo e muito sensíveis a doenças, como o "mosaico". Até 1925, no Brasil, principalmente no estado de São Paulo, eram plantadas as cultivares conhecidas como riscada, roxa, cristalina, manteiga, caiana, preta, entre outras, todas pertencentes a essa espécie;

S. spontaneum L. tem como características vigor, dureza, perfilhamento e capacidade de rebrota de soqueira, especialmente devido à resistência ao estresse, doenças e pragas. São plantas de menor porte, colmos curtos e finos, fibrosos e praticamente sem açúcar. O sistema radicular é bem desenvolvido, com grande perfilhamento da touceira, repercutindo em adaptação a condições adversas de solo 
e clima. Sobretudo as cultivares dessa espécie diferenciam das $S$. officinarum pela resistência ao vírus do mosaico. Fazem parte desda espécie as cultivares Kans, da Índia e Glagah, de Java;

S. robustum Jesw - essa espécie evoluiu da $S$. officinarum por meio de seleções humanas, à procura de tipos mais macios e ricos em caldo açucarado; as plantas apresentam porte alto, são muito fibrosas e muito pobres em sacarose e também são tolerantes à umidade e suscetíveis ao mosaico;

S. sinense Roxb - as plantas dessa espécie apresentam colmos finos, fibrosos e regularmente ricos em sacarose, sistema radicular desenvolvido e são menos exigentes em nutrientes e água; algumas cultivares são resistentes ao mosaico;

S. edule - é produto da introgressão (processo de escape gênico e instalação do transgene em outros organismos) de S. officinarum ou $S$. robustum com outro gênero, com inflorescência desenvolvida, porém algumas cultivares apresentam flores não fecundas, utilizadas na alimentação humana.

Diante de tal número de espécies, e para a obtenção de derivados de canade-açúcar de qualidade, torna-se necessário que a variedade a ser utilizada em determinado ambiente apresente boa produtividade de colmos por hectare; alto teor de sacarose; teor médio/baixo de fibra da cana; resistência às principais doenças e pragas; fácil despalha; resistência ao tombamento; boa adaptação aos diferentes tipos de solo e clima; ausência de florescimento; boa brotação de soqueira; rápido crescimento inicial e fechamento; ausência de joçal (microespinhos) e de rachaduras (FERNANDES, 2005).

Com referência ainda às variedades de cana-de-açúcar no Brasil, estas foram trazidas de outros países e muitas das delas foram erradicadas por doenças. A partir de 1950, começou a ser desenvolvida na Estação Experimental de Campos (RJ) uma variedade de nome CB (Campos-Brasil), cultivada nos canaviais brasileiros; mais tarde, após 1970, surgiram outras cultivares, obtidas nos Programas de Melhoramento da Copersucar, as variedades SP, e do IAA/Planalsucar, as variedades RB (República Brasil). Destas, destacam-se variedades como SP-701143, SP-7I-1406 e RB-72454 (MATSUOKA et al., 1999).

Na área de estudo desta pesquisa, o estado do Paraná, em torno de $80 \%$ das variedades plantadas são RBs, variedades estas desenvolvidas pelos Programas de 
Melhoramento Genético - PMGCA/UFPR, vinculados à RIDESA (Rede Interuniversitária - UFPR, UFSCar, UFV, UFRRJ, UFS, UFAL e UFRPE, UFMT, UFG - para o Desenvolvimento do Setor Sucroalcooleiro), instituição atuante desde 1991 com a extinção da PLANALSUCAR. Além dessas, há o desenvolvimento de variedades precoces, como RB946903, RB965902 e RB966928, em razão de os anos agrícolas estarem se iniciando cada vez mais cedo nesse estado (ALCOPAR, 2007).

Ainda em território brasileiro, além das variedades nacionais, outras são utilizadas, como as variedades estrangeiras $C P, Q$ e $C O$, híbridos do gênero Saccharum, nos quais se procura obter, além das características agronômicas de produtividade, características de rusticidade e resistência a pragas e doenças (NUNES JUNIOR, 1987). Destaque-se que no cerne de todas essas características tem-se o clima como fator predominante de aceitação ou rejeição de determinada variedade.

Climatologicamente, essa cultura é bem aceita em grande parte do território nacional e seu cultivo tem por finalidade principal a produção alimentícia (açúcar) e geração de energia (álcool combustível). Essa energia, em relação à advinda do petróleo, é considerada menos agressiva ao meio ambiente, embora a cana-deaçúcar destinada à produção de combustível seja um grande desafio no sentido de conciliar a expansão de áreas com uma ocupação ordenada e sustentável. Na atual conjuntura mundial, não há espaço na sociedade para uma expansão produtivista sem preocupação ambiental e social (ROSCOE, 2006).

Essa grande oportunidade de fortalecimento da agricultura brasileira através da agroenergia não terá sentido se não contemplar princípios de preservação do solo, da água, do ar, da biodiversidade e das diferenças culturais, e se não houver a inserção das populações locais, através da geração de empregos e renda.

Segundo Magalhães (1987), a produtividade média anual da cana-de-açúcar é em torno de 60 ton/ha, tendendo a aumentar com o emprego de novas tecnologias. Em muitos países produtores de cana-de-açúcar o seu rendimento é calculado por meio do peso dos colmos por área do terreno. E o seu rendimento econômico refere-se à produção de sacarose, que é o mais valioso componente, além de açúcares redutores (que contribuem para formar o melaço) e fibra (utilizada como combustível alternativo na própria usina). 
No âmbito mundial, o Brasil é o maior produtor de cana-de-açúcar, seguido pela Índia e China. Segundo dados da IBGE (2008), a produção brasileira em 2006 foi em torno de 457 milhões de toneladas, ocupando área de 6,5 milhões de hectares; a Índia, segundo maior produtor, com 345 milhões de toneladas, ocupava área aproximada de 4,0 milhões de hectares, e a China, de acordo com a FAO (2005), com 88 milhões de toneladas, tinha uma área plantada de 1,3 milhão de hectares. No ano agrícola de 2007/2008, no Brasil, houve um aumento em torno de $12 \%$ da área plantada, devendo chegar a algo em torno de 7,0 milhões de hectares e produção acima de 475 milhões de toneladas (CONAB, 2007).

Para esses países foi previsto, para o ano agrícola de 2006/07, em relação ao ano anterior, um aumento na produção de 30,9 milhões de toneladas para o Brasil, 25,1 milhões para a Índia e de 11,2 milhões para a China (USDA, 2008). No ano agrícola seguinte o Brasil continuava tendo a maior produção, 650 mil toneladas, com incremento de 32,1 milhões de toneladas, embora a produção da Índia crescesse em 1,1 milhão de toneladas e a da China em 1,0 milhão.

2.2 - Influência e variabilidade climática na produtividade agrícola da cana-deaçúcar/outras culturas

Como mostrado no item anterior, as variações diárias, sazonais e anuais nos valores dos elementos climáticos são de vital importância na determinação da eficiência do desenvolvimento e da produtividade dos vegetais cultivados. Essas variações podem ser adequadas às necessidades do cultivo ou podem estar fora da normalidade habitual, provocando adversidades agroclimáticas e consequentes oscilações nos anos agrícolas.

As variações climáticas, associadas a todos os fatores do meio físico, estão inter-relacionadas, direta e indiretamente, influenciando todo o calendário agrícola dos cultivos. Se há variabilidade climática, há necessidade de mais conhecimento 
nessa área de pesquisa, visando à adequação dos cultivos, temporal e espacialmente, e evidentemente a maior produtividade e produção (SANTOS, 1996).

Assim, algumas pesquisas sobre a influência climática na produtividade agrícola são abordadas, como segue:

Estudo de Santos (1992) sobre variabilidade e tendência da chuva e sua relação com a produção agrícola mostrou que há redução na produção da cana-deaçúcar em razão da deficiência hídrica, alcançando índices que variaram de $10 \%$ a 40\%. Santos (1975), estudando a influência da distribuição e da quantidade de chuva para a produção de cana-de-açúcar, seleciona anos padrão e observa a distribuição anual, mensal e diária das chuvas. Considera que o ano padrão seco pode ser considerado antiprodutivo, o ano padrão normal proporciona produtividade média e o ano padrão úmido é ótimo para a produção dessa cultura.

Segundo Katz (1995), as flutuações anuais na produção estão principalmente ligadas às oscilações climáticas, em especial a precipitação pluvial, embora se devam levar em conta os atributos dos solos e a tecnologia adotada.

Borsato e Sant'anna Neto (2002) mostram que as irregularidades na pluviosidade em decorrência do fenômeno El Niño causam variações de redução na produtividade; Guerra e Caramori (2003) também verificaram que a influência do ENOS sobre a precipitação traz impactos positivos e/ou negativos na produtividade das culturas.

Outros estudos (SANTOS, 1996; SAN'ANNA Neto, 1996) sobre a variabilidade das chuvas no estado de São Paulo demonstram aumento da pluviosidade em torno de $10 \%$ em praticamente todo o estado. Apenas em três unidades climáticas houve redução. Ainda segundo Santos (op. cit.), esse aumento e as mudanças na sazonalidade estão associados à diminuição da participação dos sistemas polares e frontais e a um aumento dos tropicais na gênese pluvial.

Wadsted (1983), avaliando o efeito das variáveis meteorológicas sobre os rendimentos de algumas culturas agrícolas, inclusive a cana-de-açúcar, adverte para os impactos dessas variáveis na produção e na produtividade das culturas e seus reflexos no mercado econômico. Santos (1981; 1975), estudando uma associação entre chuva e produtividade na cultura da cana-de-açúcar, verificou que a variabilidade climática é, na maioria das vezes, responsável pela oscilação na 
produção, seja ela positiva ou negativa, podendo ocorrer por excessos ou déficits hídricos. Essa autora conclui que totais médios de produção dessa cultura com os totais médios pluviométricos tiveram correlação positiva em média de 0,75 , revelando tendência de aumento nos totais de produção quando se elevam os totais pluviométricos.

\subsection{1 - El Niño Oscilação Sul (ENOS) e sua influência na produtividade agrícola}

A variabilidade climática é decorrência também de fenômenos como El Niño, que por sua vez influenciam sobremodo na produtividade agrícola. A área estudada faz parte de uma região que apresenta forte sinal do fenômeno El Niño Oscilação Sul (ENOS), especialmente em relação à precipitação pluvial, que é a principal causa da variabilidade climática em diversas regiões do globo (BERLATO, FONTANA, 2003).

Os fenômenos El Niño e La Niña são apontados, respectivamente, como causadores do aquecimento ou do resfriamento anômalos das águas de superfície do Oceano Pacífico Equatorial Leste, que estão associados ao enfraquecimento ou intensificação dos ventos alísios. A combinação do El Niño com outro importante fenômeno, a Oscilação Sul (OS), é um fator que leva ao entendimento das variações da circulação atmosférica de grande escala.

O Índice Oscilação Sul (IOS) é um fenômeno caracterizado pela diferença de pressão padronizada nas regiões de Darwin (Austrália) e de Taiti (Polinésia Francesa), causando enfraquecimento ou intensificação dos ventos alísios sobre o oceano Pacifico Equatorial. Essas regiões constituem os principais centros de ação de uma espécie de gangorra barométrica que envolve a troca de massas de ar entre os hemisférios Leste e Oeste. A oscilação da pressão atmosférica ao nível do mar (PNM) entre essas regiões provoca significativas mudanças de tempo em ambas as regiões.

A fase positiva da OS ocorre quando os sistemas de altas pressões do Pacífico Oriental e o de baixas pressões na Indonésia se intensificam, ou seja, seus desvios estão acima da média. Portanto, o IOS é considerado positivo quando a PNM do Tahiti se eleva acima de sua média, ao mesmo tempo em que a de Darwin se reduz abaixo da sua PNM média. Nessas condições, os movimentos ascendentes 
de ar se intensificam e a atividade convectiva cresce, aumentando as precipitações sobre a Indonésia e norte da Austrália. Ao mesmo tempo, cresce a atividade convectiva sobre a Amazônia e o Nordeste brasileiro.

Esse fenômeno, que interfere na circulação atmosférica, está muitas vezes associado à intensificação ou enfraquecimento dos eventos El Niño e La Niña. A associação entre IOS e El Niño (ou La Niña) é denominada El Niño Oscilação Sul (ENOS). Tanto El Niño quanto La Niña podem ser respectivamente classificados como fase positiva e fase negativa do ENOS. Em geral, IOS positivo é associado a La Niña, enquanto que IOS negativo está associado a El Niño (MOLION, 1989; GALVANI, 1995; BERLATO; FONTANA, 2003).

A ocorrência desse evento pode influenciar de forma positiva ou negativa na produtividade das culturas agrícolas, por provocar uma alteração de grande escala e interferir na circulação geral da atmosfera.

Rossin e Tommaselli (2009), estudando efeitos do clima sobre a produção da cana-de-açúcar no estado de São Paulo, observaram que em ano de La Niña houve redução significativa na produtividade dessa cultura, em razão de deficiência hídrica nos períodos de maior exigência hídrica.

Berlato e Cordeiro (2005) pesquisaram sobre variabilidade climática na agricultura do Rio Grande do Sul e concluíram que a maior produtividade para a cultura da soja foi durante a década de 1990, em anos de El Niño (1991/92, 1992/93, 1993/94, 1994/95 e 1997/98), períodos estes em que o volume de chuva esteve acima da média. Nesse mesmo estudo, verificaram ainda que, para a série de dados dos últimos 25 anos, a correlação entre chuva e produtividade da soja foi de $r=0,78$, com $1 \%$ de significância ou $99 \%$ de confiança. Nessa mesma linha de estudo e mesma região, apenas utilizando outra cultura, Berlato et al. (2005) concluíram que El Niño (anos chuvosos) determina ganhos e La Niña (anos secos) redução de produtividade do milho.

A produtividade do trigo no Brasil, em particular na região Sul, também é influenciada pelo fenômeno ENSO, que em geral causa impactos positivos em anos de La Niña e negativos em anos de El Niño (CUNHA et al., 1999). No estado do Paraná, Prela (2004) trabalhou com essa cultura para o período de 1976 a 2002 e identificou queda de produtividade do trigo em anos de El Niño nas regiões Centro- 
Oeste e Oeste e tendência de acréscimo na região Sul em épocas de La Niña. Nas demais regiões, essa autora não encontrou efeito significativo desse fenômeno.

\section{3 - Condições térmicas e sua relação com a cultura canavieira}

Enfatizando a variabilidade termopluviométrica, tem-se que, dentre outros, os fatores de disponibilidade de energia e de água determinam a produtividade de uma cultura agrícola. Falta ou excesso de água afetam o desenvolvimento das plantas, bem como a temperatura condiciona o ciclo de desenvolvimento e a duração dos estádios fenológicos dos vegetais (REICHARDT, 2004).

Portanto, para a produção dessa cultura, a temperatura é, provavelmente, de maior importância. A temperatura basal para a cana-de-açúcar está em torno de $20^{\circ} \mathrm{C}$. A temperatura ótima situa-se entre $22^{\circ} \mathrm{C}$ e $30^{\circ} \mathrm{C}$, sendo que nessas condições a cultura apresenta seu máximo crescimento. Acima de $38^{\circ} \mathrm{C}$ não há crescimento e abaixo de $20^{\circ} \mathrm{C}$ o desenvolvimento da cultura é considerado nulo (BARBIERI et al., 1977). Segundo Fauconier (1975), citado por Scarpari (2002), o crescimento da cana é máximo no intervalo de temperatura entre $30^{\circ} \mathrm{C}$ e $34^{\circ} \mathrm{C}$, é lento abaixo de $25^{\circ} \mathrm{C}$ e acima de $35^{\circ} \mathrm{C}$, e é praticamente nulo acima de $38^{\circ} \mathrm{C}$. Há ainda aqueles que consideram que a faixa ideal para desenvolvimento da cultura da cana-de-açúcar situa-se entre $20^{\circ} \mathrm{C}$ e $35^{\circ} \mathrm{C}$ (PLANALSUCAR, 1986; CASAGRANDE, 1991).

A região Centro-Sul do Brasil, de modo geral, e em especial o estado do Paraná, caracteriza-se pela variabilidade interanual do clima. Essa falta de regularidade cronológica dos fenômenos climáticos lhe confere caráter de risco à agricultura, dificultando dessa forma o planejamento da época do plantio e condução do cultivo (WREGE et al., 2005).

Segundo Grodzki et al. (1996), quando a temperatura mínima do abrigo termométrico (a $1,5 \mathrm{~m}$ da superfície do solo) alcança em torno de $3^{\circ} \mathrm{C}$, a temperatura da relva é de aproximadamente $-1^{\circ} \mathrm{C}$. Isso pode causar dano à cultura da cana-deaçúcar e a outras culturas de clima tropical, levando-se em conta o tempo de permanência de baixa temperatura e o estádio de desenvolvimento da planta (PARANHOS, 1987). A cana-de-açúcar é muito sensível à geada, principalmente as gemas e as folhas, que se danificam com temperaturas em torno de $0^{\circ} \mathrm{C}$ a $3,9^{\circ} \mathrm{C}$ 
(BACCHI et al., 1980; BRINHOLI, 1978). Camargo e Ortolani, citados por Rodrigues (1995), também afirmam que áreas propensas a geadas frequentes e destrutivas devem ser consideradas inaptas para o cultivo da cana-de-açúcar.

Destaque-se que, do ponto de vista meteorológico, geada é definida como o processo através do qual cristais de gelo são depositados sobre uma superfície exposta. A geada agronômica ocorre quando a temperatura do ar atinge temperaturas tão baixas que levem ao congelamento dos tecidos vegetais, provocando a morte da planta ou de suas partes (MOTA, 1979).

Caramori et al. (2007), analisando as séries históricas de dados, verificaram a ocorrência de geadas quando as temperaturas mínimas no abrigo meteorológico eram inferiores a $3^{\circ} \mathrm{C}$. O estado do Paraná, assim, foi dividido em zonas de risco, mediante uma relação com a altitude e a latitude, variáveis que têm alta correlação com a ocorrência de temperaturas baixas e geadas. Esse estado apresenta regiões com mais de 1.200 metros de altitude na porção Sul, menos de 300 metros no vale do rio Paranapanema (Norte) e valores inferiores a 200 metros no vale do rio Paraná (Oeste).

As épocas de maior probabilidade de ocorrência de geada no Paraná (Figura 1) são os meses de junho, julho e agosto. Em julho são comuns temperaturas mínimas inferiores a $3^{\circ} \mathrm{C}$, criando condições propícias à geada (CAVIGLIONE et al., 2000). Em junho e agosto é comum também a ocorrência de geada em todas as regiões, mas com risco mais baixo; nesses meses, é possível não ocorrer geada em algumas regiões, principalmente nos anos mais quentes. Em setembro é baixo o risco de ocorrer geada, exceto nas áreas de altitude elevada (WREGE et al., 2005); 

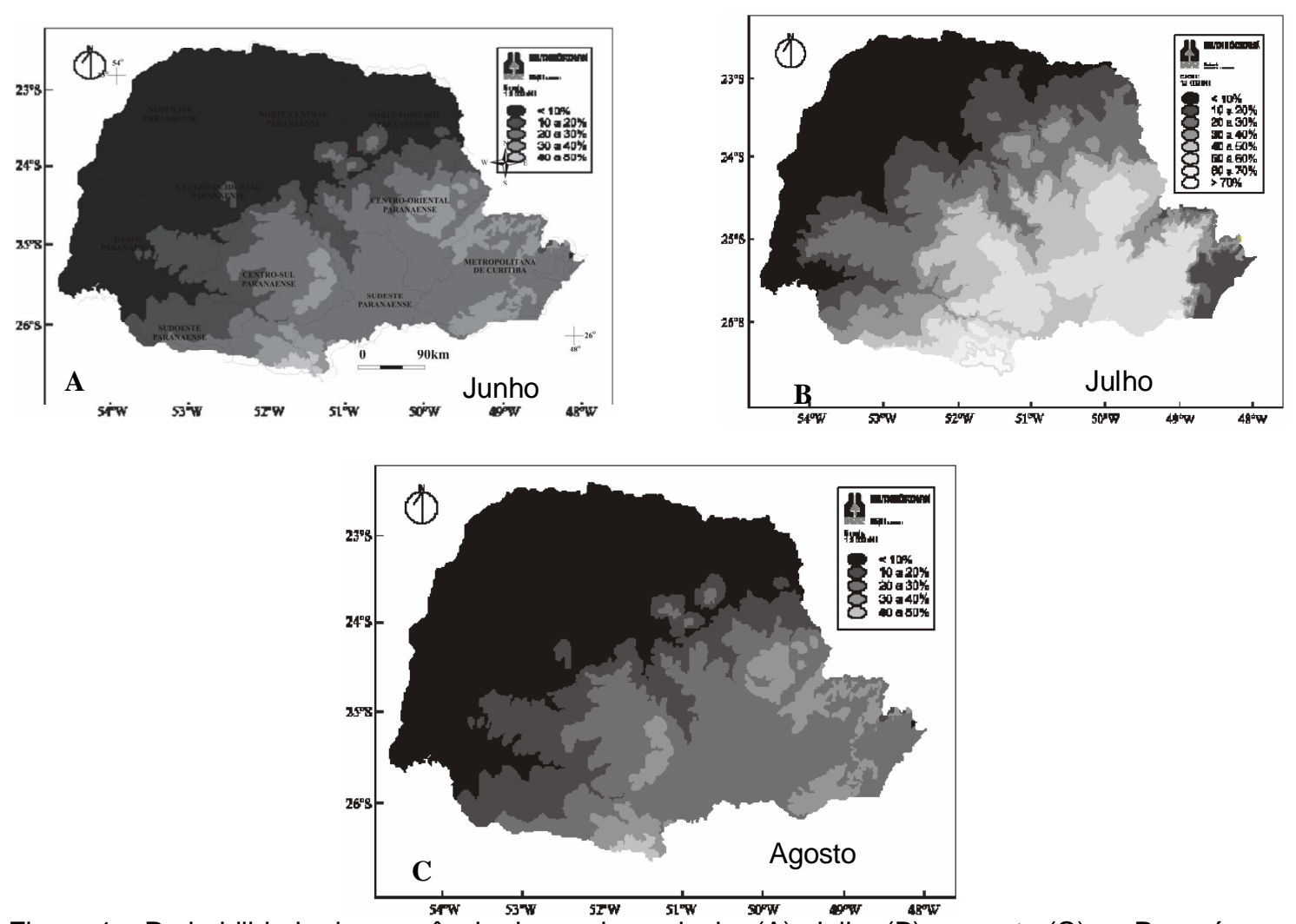

Figura 1 - Probabilidade de ocorrência de geada em junho (A), Julho (B) e agosto (C) no Paraná. (Mod. Wrege et al., 2005).

As regiões paranaenses com maior aptidão térmica para o cultivo de cana-deaçúcar foram delimitadas por Wrege et al. (2005) (Figura 2). Riscos de geada diminuem nas localidades situadas em latitude menores que a do paralelo de $24^{\circ} \mathrm{S}$, abrangendo principalmente as regiões Norte e Noroeste. Segundo Nagarolli (2007), as maiores variabilidades nas temperaturas mínimas ocorreram principalmente nos anos de 1971, 1977, 1983 e 1998, com destaque para as regiões Norte, Noroeste e Leste desse estado. 


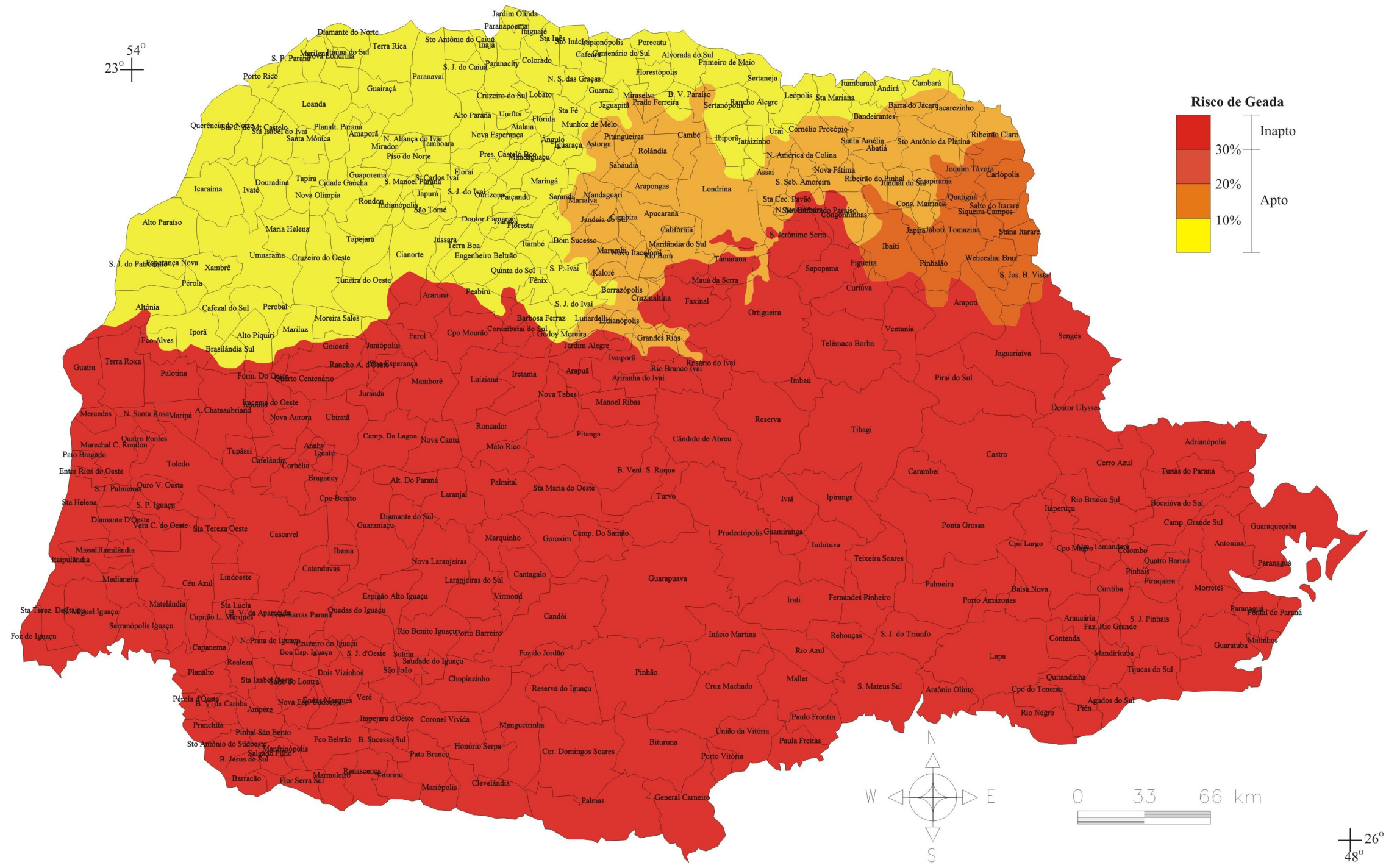

Figura 2 - Regiões com aptidão térmica para o cultivo da cana-de-açúcar no Paraná. Adaptado de Wrege et al. (2005). Org.: Domingues, I.A.S., (2007). 


\subsection{Condições hídricas e sua relação com o cultivo da cana-de-açúcar}

Quanto às condições pluviométricas no Paraná, registram-se médias anuais que variam de $1.200 \mathrm{~mm}$ (partes das regiões Noroeste e Norte) a $3.500 \mathrm{~mm}$ (parte do Sudeste e Leste - litoral). O trimestre mais chuvoso - dezembro, janeiro e fevereiro (verão) - varia de $400 \mathrm{~mm}$ (partes das regiões Noroeste, Oeste, Centro e Sul) a $1.200 \mathrm{~mm}$ (partes da região Leste), e o mais seco - junho, julho e agosto (inverno) registra médias entre $150 \mathrm{~mm}$ (partes das regiões Norte e Noroeste) e acima de 450mm (partes das regiões Sul e Sudeste) (CAVIGLIONE et al., 1997). Nery et al. (1997) identificaram que os maiores valores de precipitações estão concentrados no Nordeste e Leste.

Nagarolli (2007) utilizou série temporal de 1970 a 1999 das estações climatológicas do IAPAR e verificou que no Norte do estado ocorreu um total de precipitação média menor que o da região Sudoeste, ficando o total anual entre $1.500 \mathrm{~mm}$ e $1.600 \mathrm{~mm} / \mathrm{ano}^{-1}$. As regiões Sul, Leste e Sudoeste registraram as maiores elevações pluviais, destacando-se os municípios de Francisco Beltrão e Laranjeiras, no Sudoeste, com os mais elevados totais pluviométricos do estado.

Sendo a chuva um fator influenciador da produtividade agrícola, para a canade-açúcar uma precipitação pluvial anual em torno de $1.000 \mathrm{~mm}$, bem distribuída, é suficiente para a obtenção de alta produtividade. Isso implica que o manejo hídrico seja realizado com eficiência, com suprimentos hídricos adequados durante o desenvolvimento vegetativo (principalmente nas fases de germinação, perfilhamento e alongamento dos colmos) e alguma restrição no período de maturação, para forçar o repouso fisiológico e o enriquecimento em sacarose (INMAN-BAMBER; SMITH, 2005); caso contrário, ela permanecerá vegetando sem acumular sacarose.

Nessas condições de desenvolvimento, levando em consideração cada estádio fenológico, a planta cana-de-açúcar tem uma exigência evapotranspirativa de acordo com seu crescimento e desenvolvimento denominada Evapotranspiração de Cultura (ETc). A ETc é dependente de um coeficiente de ajuste denominado Coeficiente de Cultura (Kc). Este, por sua vez, é função do Índice de Área Foliar (IAF) da cultura. O Kc em uma cultura anual varia de acordo com seus estádios fenológicos. Seus valores normalmente são de 0,3 na fase de estabelecimento da 
cultura a 1,2 no florescimento e frutificação. Observa-ser um aumento gradual até o estádio do florescimento, que coincide com a época de máxima área foliar, decrescendo a partir do final da frutificação e início da maturação em razão da senescência das folhas.

Nagarolli (2007) analisou dados de 27 estações meteorológicas do estado do Paraná para um período entre 23 e 28 anos, 1970/76 a 1999, e verificou que os anos com totais de chuva muito abaixo da média (menor $1.100 \mathrm{~mm}$ ) ocorreram principalmente nos anos de 1978, 1984,1985 1988, 1991, 1994 e 1999, na maioria das regiões.

Segundo Ometto (1988), o valor da água prontamente disponível (APD) no solo para cana-de-açúcar é de $68 \%$ da capacidade de água disponível (CAD). Se essa condição prevalecer durante todo o ciclo da cultura, considerando-se os demais fatores em condições ótimas, tem-se uma produtividade máxima. Nas principais regiões brasileiras produtoras de cana-de-açúcar, o consumo diário de água por essa cultura, dependendo de uma série de fatores, pode ter variação de $2,0 \mathrm{~mm} / \mathrm{dia}$ a $6,0 \mathrm{~mm} / \mathrm{dia}$.

Em condições de campo, a cana-planta consome o máximo de 4,5mm/dia de água, o mínimo de 2,3mm/dia, e o consumo médio é de $3,3 \mathrm{~mm} / \mathrm{dia}$, enquanto que na soca o consumo máximo é de $4,4 \mathrm{~mm} /$ dia, o mínimo é de 2,2mm/dia, e média é de é 3,2mm/dia (SCARDUA, 1987).

Inman-Bamber (2004) apresenta dados segundo os quais, se ocorrer estresse hídrico durante o desenvolvimento da cultura da cana-de-açúcar, haverá uma restrição dos processos fisiológicos, como a divisão celular e sua elongação, causando danos como a diminuição na taxa de acúmulo de massa seca, na taxa de elongação da cultura e no Índice de Área Foliar.

De acordo com Maule et al. (2001), falta ou excesso de água no solo afetam de maneira significativa o desenvolvimento da área foliar da cana-de-açúcar. No entanto, efeito de déficit no período de maturação pode ser considerado insignificante na produtividade da cana-de-açúcar (SCARDUA, 1987). Comumente as maiores reduções de produtividade ocorrem nos primeiros 8 meses após o plantio. 
Ainda em relação ao déficit hídrico, áreas que não apresentam estação seca não favorecem a maturação e a colheita da cana-de-açúcar. Por outro lado, déficit hídrico em torno e ou acima de $400 \mathrm{~mm}$ também não é favorável a essa cultura. Citese, por exemplo, estudo sobre sazonalidade da precipitação no estado do Paraná, que evidenciou tendência de aumento de precipitação na estação de outono (NAGAROLLI, 2007), que normalmente coincide com o estádio de maturação na maioria das áreas de cultivo da cana-de-açúcar.

Além disso, um fator que favorece a planta da cana-de-açúcar em situação de seca é a capacidade que ela tem de desenvolver um sistema radicular que atinge profundidades de até cinco metros, podendo, dessa forma, retirar água das camadas mais profundas, e, portanto, suportar mais facilmente os períodos com deficiência hídrica (DOORENBOS; KASSAN, 1994).

\section{5 - Condições energéticas e sua relação com a cultura da cana-de-açúcar}

De acordo com Camargo (1968) e Magalhães (1987), o desenvolvimento da cana-de-açúcar, quando cultivada em área com mais disponibilidade de radiação solar, apresenta variação nas características morfológicas e fisiológicas. Nessas condições, os colmos se apresentam mais grossos, mais curtos, as folhas mais largas e verdes, e o perfilhamento mais intenso. O colmo é cilíndrico, ereto, fibroso e constituído de nós e internódios, sua altura varia de 1,0m a 5,0m e o diâmetro pode variar desde menos de $1,0 \mathrm{~cm}$ até $5,0 \mathrm{~cm}$. Cada colmo produz uma nova folha a cada 10 dias aproximadamente. O colmo é o fruto agrícola da cana-de-açúcar em cujos vacúolos das células a sacarose se acumula no período de maturação (TAUPIER; RODRIGUES, 1999).

Ainda sobre os colmos, ressalte-se que o teor de sacarose no caldo é diretamente influenciado pela quantidade de luz e o seu crescimento aumenta para comprimento de dias de 10 a 14 horas e diminui em condições de fotoperíodos longos de 16 a 18 horas.

O desenvolvimento da planta da cana-de-açúcar também depende do acúmulo de unidades térmicas durante o seu ciclo vegetativo. O somatório térmico ou constante térmica (graus-dia) expressa a quantidade de energia de que a planta 
necessita para atingir certo grau de maturidade (PEREIRA, 2002). A exemplo, para planta de primeiro ano o acúmulo de graus-dia em torno dos 120 dias atinge alcança aproximadamente $500^{\circ} \mathrm{C}$, enquanto que para cana de segundo ano (brotação) o acúmulo é em torno de $400^{\circ} \mathrm{C}$ aos 130 dias (Figura 3), (ALVAREZ et al., 2000).

O conceito de graus-dia (GD) baseia-se no fato de que a taxa de desenvolvimento de uma espécie vegetal está relacionada à temperatura do meio. Esse conceito pressupõe a existência de temperaturas basal inferior (Tb) e superior (TB), valores térmicos aquém ou além dos quais as plantas não se desenvolvem, e, se o conseguirem, será a taxas muito reduzidas (PEREIRA, 2002).

Villa Nova et al. (1983) consideram que o melhor método para correlacionar o desenvolvimento dos vegetais e a temperatura é o dos graus-dia, que corresponde à área compreendida entre a temperatura base, abaixo da qual o desenvolvimento é considerado nulo, e a curva da temperatura diária. 

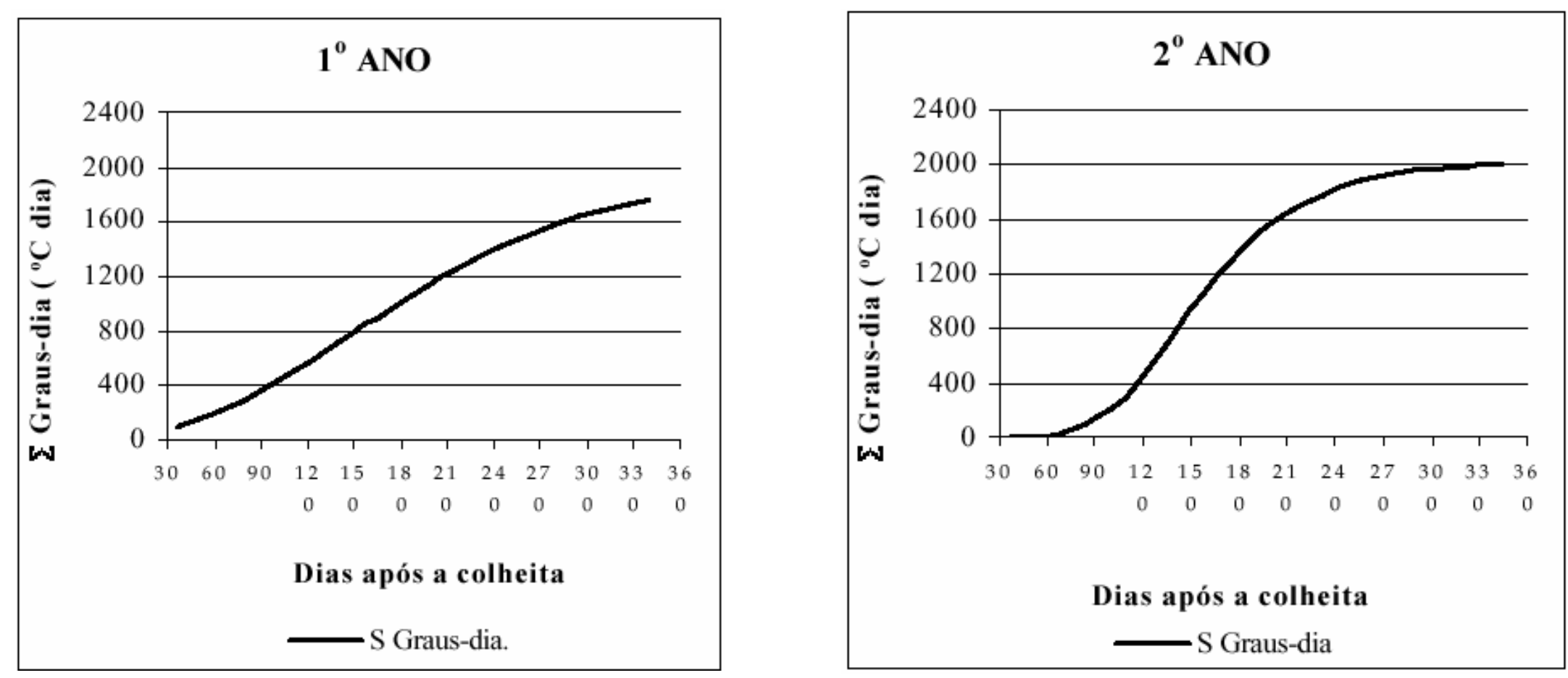

Figura 3 - Acúmulo de graus-dia (ํㅡ/d) da cana-de-açúcar de primeiro e segundo ano. Fonte: Pereira (2000). 
$\mathrm{Na}$ cultura da cana-de-açúcar os principais drenos de carboidratos são representados pelo crescimento da área foliar e do sistema radicular, além do próprio acúmulo de sacarose no colmo, sendo a sacarose acumulada em altas concentrações nos entrenós maduros, ao contrário do que acontece em entrenós "jovens". Em plantas jovens, até 4 meses, os carboidratos sintetizados pelas folhas são direcionados basicamente para o crescimento vegetativo, enquanto que as plantas maduras, com mais de 4 meses, têm como drenos preferenciais tanto o crescimento vegetativo quanto o acúmulo de sacarose no colmo, sendo este último evento predominante na fase final de maturação (SEGATO et al., 2006). Estudando a fotossíntese e o conteúdo foliar de carboidratos em cana-de-açúcar, Machado et al., (2008) verificaram que na fase de maturação há aumento no conteúdo de sacarose nas folhas devido à força de dreno exercida pelo acúmulo desse carboidrato no colmo.

Assim, é importante destacar que a produtividade da cana-de-açúcar é dada tanto pelo peso dos colmos quanto pelo teor de sacarose. O teor de sacarose nos colmos deve ser acima de $15 \%$ do peso fresco, pois é ele que determina a produção de açúcar ou de álcool por tonelada de cana. O perfilhamento, que consiste na formação de vários colmos a partir de uma única planta, também é favorecido por alta intensidade luminosa; o número de brotos vivos depende da quantidade de luz incidente.

Christoffoleti (1986) também verificou que a baixa luminosidade tende a reduzir o perfilhamento da planta de cana-de-açúcar. Em seu experimento, avaliou plantas que foram deixadas em casa-de-vegetação sob baixa luminosidade, e que apresentaram maior número de perfilhos mortos. Entretanto, o mesmo não ocorreu quando a cultivar foi manejada em ambiente com maior luminosidade. Efeito similar foi observado por Casagrande (1991), quando estudou a influência da temperatura no perfilhamento. Em seus resultados, evidenciou que o perfilhamento aumenta em ambientes com temperaturas elevadas até o máximo de $30^{\circ} \mathrm{C}$. O efeito de temperaturas menores no perfilhamento foi relatado por Inman-Bamber (1994). Segundo esse autor, temperaturas próximas aos $16^{\circ} \mathrm{C}$ levariam a uma estabilização no número de perfilhos.

Segundo Magalhães (1987), a cana-de-açúcar perfilha abundantemente na fase inicial do desenvolvimento. Quando se estabelece como uma cultura, o 
autossombreamento induz uma inibição do perfilhamento e uma aceleração do crescimento do colmo principal, que continua até a ocorrência de alguma limitação no suprimento de água ou ocorrência de temperaturas baixas.

Por ser essa uma planta melhor adaptada às regiões entre as latitudes em torno de $35^{\circ} \mathrm{N}$ a $30^{\circ} \mathrm{S}$ e em altitudes que variam desde o nível do mar até $1.000 \mathrm{~m}$, sofre as influências do clima em todo o curso do ano (MAGALHÃES, 1987). Para a região Centro-Sul, onde o estado do Paraná está inserido, os agentes atuantes na produtividade, segundo Brasil (2008), são principalmente a deficiência hídrica anual, a temperatura média anual, a precipitação na colheita e a evapotranspiração anual. Como a brotação dos toletes dessa planta exige calor e umidade suficientes, a época de plantio depende das condições locais adequadas ao período vegetativo.

Outro fator importante, no que diz respeito ao crescimento/rendimento da cultura da cana-de-açúcar, é o Índice de Área Foliar (IAF). O IAF é uma relação que expressa no numerador a superfície foliar e no denominador a superfície do solo, ou seja, refere-se à área de folhas existente dentro de uma determinada área de solo ocupada pela planta $\left(\mathrm{m}^{2}\right.$ folhas $/ \mathrm{m}^{2}$ solo) (RODRIGUES, 1995; OMETTO, 1981). Seus processos fisiológicos estabelecem a capacidade para a captura da energia solar e a síntese de produtos necessários para sustentar o desenvolvimento da estrutura das plantas. A maior ou menor capacidade de captura da radiação está prioritariamente relacionada à área foliar. Ainda conforme Ometto (1981, à medida que a cultura vai crescendo, vai aumentando o número de folhas e dessa maneira aumentando a superfície foliar e o número de folhas utilizadas na fotossíntese, crescendo com isso a absorção do $\mathrm{CO}_{2}$ e estimulando cada vez mais a evapotranspiração. O resultado de tudo isso é o acréscimo da matéria seca, que intrinsicamente vem a sintetizar todas as relações planta-meio.

A taxa de crescimento é uma função do Índice de Área Foliar e a eficiência fotossintética das folhas (Tabelas 1 e 4). Ele aumenta com a idade da planta, que terá maior capacidade de interceptar a luz incidente. O Índice de Área Foliar é "crítico" quando 95\% da luz incidente for interceptada. No Índice de Área Foliar máximo, a taxa de formação de folhas novas é igual à de morte das folhas inferiores (GOMIDE, 1994; 1986; MONTEIRO; MORAES, 1996). 
Conforme Monteiro e Morais (1986), se a taxa respiratória das folhas for independente da luz, haverá um Índice de Área Foliar (IAF) “ótimo", em que a taxa de crescimento é máxima, quando a relação taxa de fotossíntese/taxa respiratória é máxima. Ao superar o valor de IAF "ótimo", haverá um número cada vez maior de folhas sombreadas, à medida que novas folhas se formem nas partes mais altas do extrato arbóreo (GOMIDE, 1994). Devido ao sombreamento, as folhas começam a senescer e morrer. Folhas sombreadas apresentam senescência acelerada, contribuindo menos para a produção de matéria seca total. Quanto mais rápido a cultura atingir o IAF máximo, e quanto mais tempo a área foliar permanecer ativa, maior será a produtividade da cultura (CASTRO, 1987).

Oliveira (2004), estudando o crescimento e desenvolvimento de três cultivares de cana-de-açúcar, cana-planta, na região de Paranavaí, PR, determinou que o IAF de uma das três variedades pesquisadas (RB855113) apresentou na maioria dos estádios os maiores valores (Figura 4). Em outras pesquisas, valores máximos de IAF entre 7,$60 ; 5,00 ; 3,70 ; 4,11$ e $7,00 \mathrm{~m}^{2} / \mathrm{m}^{2}$ foram encontrados (SAN JOSÉ; MEDINA, 1970; YOON, 1971; MACHADO, 1981; ROBERTSON et al., 1999; KEATING et al., 1999, citados por OLIVEIRA ASSIS et al., 2004). Alvarez et al. (2000) encontraram aumento gradual nos valores de IAF de cana crua de primeiro ano a partir de 180 dias, chegando a $0,09 \mathrm{~m}^{2} / \mathrm{m}^{2}$, e após esse período houve uma estabilidade em torno desse valor.

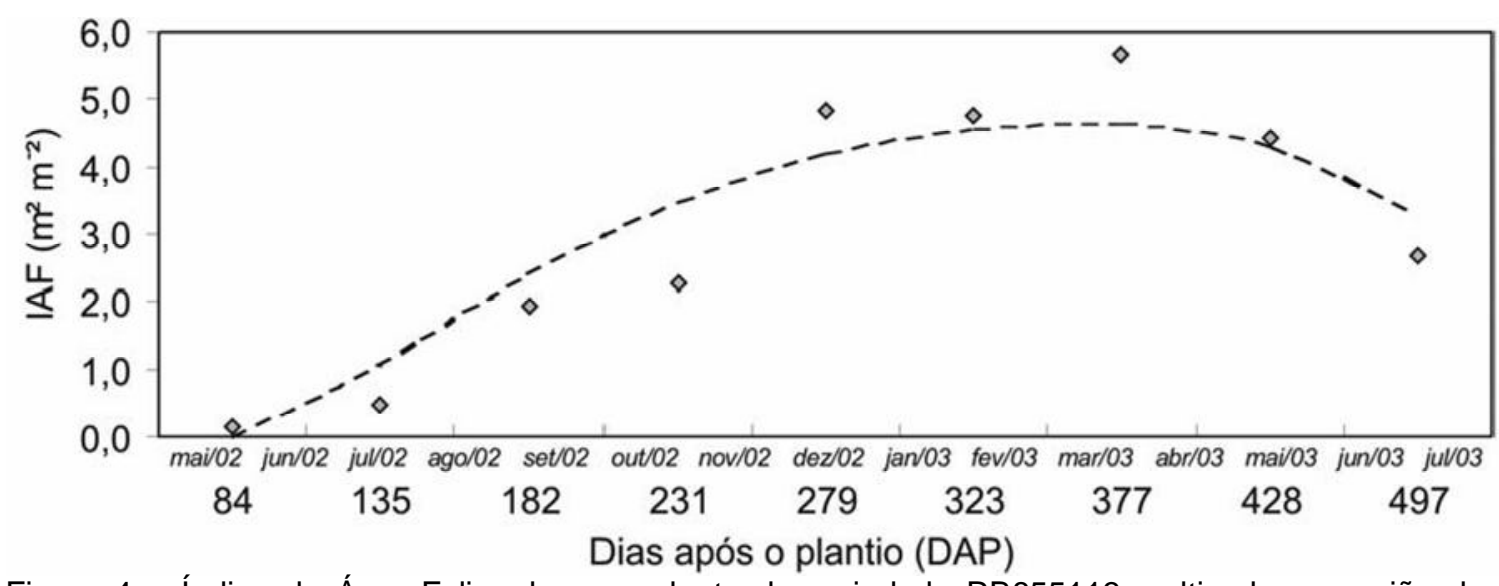

Figura 4 - Índice de Área Foliar de cana-planta da variedade RB855113, cultivada na região de Paranavaí, PR.

Fonte: Oliveira et al. (2004). 


\section{6 - Condições edáficas e sua relação com o cultivo da cana-de-açúcar}

Dessa forma, o consumo de água se dá pelo sistema radicular da planta, que pode atingir em torno de $5 \mathrm{~m}$ de profundidade, embora em áreas irrigadas $100 \%$ da água seja extraída de 1,2m a 2,0m de profundidade, no máximo. Vale lembrar que a distribuição do sistema radicular apresenta em torno de $50 \%$ (em peso) de raízes nos primeiros $20 \mathrm{~cm}$ de profundidade e $85 \%$ até os $60 \mathrm{~cm}$ de profundidade do solo (BLACKBURN, 1984). Sampaio et al. (1987) constataram que $75 \%$ das raízes encontravam-se nos primeiros $20 \mathrm{~cm}$ de profundidade do solo e que $55 \%$ delas estavam concentradas num raio de $30 \mathrm{~cm}$ da touceira. Segundo Borges et al. (2008), o sistema radicular efetivo da cana-de-açúcar está concentrado nos primeiros $60 \mathrm{~cm}$ de solo, onde se encontra $83 \%$ da massa de raízes.

Segundo Teruel et al., (2000), o suprimento de água e nutrientes das plantas depende das interações entre os complexos processos fisiológicos e celulares ocorrentes no sistema radicular, que resultam numa arquitetura específica (habilidade de a planta adquirir os recursos do solo), e os não menos complexos processos iônicos e de transporte ocorrentes no solo (disponibilidade dos recursos do solo às raízes).

Segundo Hudson (1969), citado por Buso, (2006), os solos de áreas com alta produtividade de cana-de-açúcar normalmente apresentam grande capacidade de armazenamento de água, dando suporte para elevada densidade de raízes no subsolo e, consequentemente, elevada produtividade. Isso significa que a produção de cana-de-açúcar pode ser mais econômica em um solo com média fertilidade, com alta disponibilidade de água para permitir o desenvolvimento das raízes em profundidade, do que em um solo com alta fertilidade e mais reduzida disponibilidade de água, não promovendo o crescimento radicial em profundidade, mas concentrando-o na superfície (BARAN et al., 1974, citado por BUSO, 2006).

Diante do exposto, é importante destacar que a cana-de-açúcar se desenvolve nos mais diversos tipos de solos, desde os muito arenosos aos muito argilosos e compactos. Os solos mais adaptados ao seu cultivo devem ser profundos, bem arejados e com boa capacidade de retenção de água e nutrientes. Apesar de sua exigência em água, essa cultura não se adapta bem em solos de 
baixadas úmidas (Gleissolos e Neossolos mal drenados). Os solos encharcados não oferecem aeração suficiente às plantas, dificultando o desenvolvimento do sistema radicular e a assimilação dos nutrientes. Quando excessivamente úmidos, chegam a ocasionar a morte das plantas. Em zonas sujeitas ao fenômeno da geada, devem ser evitados os terrenos baixos, de difícil circulação de ar. Nos grandes cultivos mecanizados, deve-se dar preferência aos solos com relevo praticamente plano, suave ondulado, a ondulado com declives até $12-13 \%$. No que tange às propriedades físicas, solos de textura média e argilosa, de estruturação granular e com profundidade efetiva acima de $1,50 \mathrm{~m}$, são dos mais recomendados ao bom desenvolvimento da cultura.

Assim, de acordo com Rosolen (1994), o que define a profundidade das raízes da cana-de-açúcar é a água, pois a sobrevivência delas varia durante o ano agrícola em razão das chuvas. Quando ocorre veranico e a superfície seca, sobrevivem as raízes que se aprofundam para as partes mais úmidas. Esse autor relata ainda que, quando o sistema radicial da cana-de-açúcar fica concentrado nos primeiros $40 \mathrm{~cm}$ de solo, a cultura pode suportar um estresse hídrico de 8 dias, enquanto que, se a profundidade explorada passasse para $1,10 \mathrm{~m}$, o período seco poderia atingir até 22 dias.

\section{7 - Desenvolvimento da planta cana-de-açúcar}

A produtividade da cana-de-açúcar está associada ao conteúdo de sacarose e este depende diretamente da atividade fotossintética (MACHADO et al., 2008).

Em decorrência do seu ciclo perene, a cana-de-açúcar (Saccharum spp) está sob a influência da variabilidade climática anual em todos os estádios desse ciclo. Como toda gramínea tropical, é uma planta com alta capacidade fotossintética, ou seja, sua estrutura apresenta alta afinidade em fixar $\mathrm{CO}_{2}$ (planta $\mathrm{C}_{4}$ ). Seu maior desenvolvimento e crescimento ocorrem em regiões mais quentes (MATSUOKA, 1996).

Altas taxas fotossintéticas favorecem a melhor produção dessa cultura (ALFONSI et al., 1987), embora a taxa fotossintética varie com a idade das folhas e 
apenas aquelas recém-expandidas atinjam valores de fixação de $\mathrm{CO}_{2}$ característicos das plantas $\mathrm{C}_{4}$, sendo que as folhas mais velhas, e também as muito jovens, realizam fotossíntese em taxa semelhante à das plantas $C_{3}$, (MAGALHÃES, 1987), (Tabela 1).

Tabela 1 - Características de plantas $\mathrm{C}_{4}$ (gramíneas tropicais).

\begin{tabular}{|c|c|}
\hline \multirow[t]{2}{*}{ Parâmetros } & Mecanismo Fotossintético \\
\hline & C4 \\
\hline Taxa máxima de fotossíntese ( $\mathrm{mg} \mathrm{CO}_{2} / \mathrm{dm}^{2} /$ de folha/h) & 40 a 80 \\
\hline Temperatura do dia, variação ótima para fixação de $\mathrm{CO}_{2}$ & $35^{\circ} \mathrm{C}$ a $45^{\circ} \mathrm{C}$ \\
\hline Taxa de crescimento máximo (g MS*/m².dia) & 51 a 54 \\
\hline Taxa de transpiração $\quad$ ( $\mathrm{g} \mathrm{H}_{2} \mathrm{O} / \mathrm{g}$ MS produzida $)$ & 250 a 350 \\
\hline $\begin{array}{l}\text { Inibição da fotossíntese pelo } \mathrm{O}_{2} \text { (em função da alta afinidade } \\
\text { pelo } \mathrm{CO}_{2} \text { ) }\end{array}$ & $<5 \%$ (baixa) \\
\hline kg MS/kg Nitrogênio & 74 \\
\hline
\end{tabular}

Para atingir elevada produção de sacarose, a planta da cana-de-açúcar precisa de temperatura do ar e umidade do solo adequadas para permitir o máximo crescimento na fase vegetativa, seguida de restrição hídrica ou térmica para favorecer o acúmulo de sacarose no colmo na época do corte. As baixas temperaturas ou restrição hídrica permitem que haja repouso fisiológico e consequentemente maior acúmulo de sacarose (ANDRADE, 2006).

Portanto, um ambiente mais adequado deve proporcionar um período quente e úmido, com intensa radiação solar durante a fase de crescimento, seguido de um período seco durante as fases de maturação e colheita (BARBIERI; VILLA NOVA, 1977; DOORENBOS; KASSAM, 1994; MAGALHÃES, 1987; ALFONSI, 2000, entre outros) (Tabela 2). Ainda é importante destacar que a maturação da cana-de-açúcar é tida como um processo fisiológico que envolve a síntese dos açúcares nas folhas, translocação dos produtos formados e estocagem da sacarose no colmo e esse processo é executado por meio de energia radiante (FERNANDES, 1982; CASTRO, 
1999), principalmente aquela da região da faixa visível do espectro eletromagnético $(0,4 \mu \mathrm{m}$ a $0,7 \mu \mathrm{m})(\mathrm{TAIZ}, \mathrm{ZEIGER}, 1990)$.

Tabela 2 - Aptidão climática para a cana-de-açúcar para o território brasileiro (CAMARGO et al., 1977).

\begin{tabular}{|c|c|}
\hline $\begin{array}{l}\text { Condições } \\
\text { regionais }\end{array}$ & Condições climáticas \\
\hline I Apta & $\begin{array}{l}\text { Condições satisfatórias: temperatura média anual acima de } 20^{\circ} \mathrm{C} \text { e deficiência } \\
\text { hídrica anual inferior a } 200 \mathrm{~mm} \text {; }\end{array}$ \\
\hline II Marginal & $\begin{array}{l}\text { Restrição térmica: temperatura média anual entre } 18^{\circ} \mathrm{C} \text { e } 20^{\circ} \mathrm{C} \text {; temperatura de } \\
\text { julho acima de } 14^{\circ} \mathrm{C} \text { e deficiência hídrica abaixo de } 200 \mathrm{~mm} \text {; }\end{array}$ \\
\hline III Marginal & $\begin{array}{l}\text { Restrições hídricas, justificando irrigações suplementares: temperatura média } \\
\text { anual superior a } 18^{\circ} \mathrm{C} \text { e deficiência hídrica entre } 200 \mathrm{~mm} \text { e } 400 \mathrm{~mm} \text {; }\end{array}$ \\
\hline IV Marginal & $\begin{array}{l}\text { Inapta por falta de estação de repouso, por frio ou seca: temperatura média anual } \\
\text { superior a } 24^{\circ} \mathrm{C} \text { e deficiência hídrica anual nula; }\end{array}$ \\
\hline V Inapta & Insuficiência hídrica: deficiência hídrica anual superior a 400mm; \\
\hline VI Inapta & $\begin{array}{l}\text { Carências térmicas ou geadas excessivas: temperatura média anual inferior a } \\
18^{\circ} \mathrm{C} \text { ou temperatura média de julho inferior a } 14^{\circ} \mathrm{C} \text {. }\end{array}$ \\
\hline
\end{tabular}

Como mostrado no item anterior, as variações diárias, sazonais e anuais nos valores dos elementos climáticos são de vital importância na determinação da eficiência do desenvolvimento e da produtividade dos vegetais cultivados. Essas variações podem ser adequadas às necessidades do cultivo ou podem estar fora da normalidade habitual, provocando adversidades agroclimáticas e consequentes oscilações nos anos agrícolas.

As variações climáticas, associadas a todos os fatores do meio físico, estão inter-relacionadas, direta e indiretamente, influenciando todo o calendário agrícola dos cultivos. Se há variabilidade climática, há necessidade de mais conhecimento nessa área de pesquisa, visando à adequação dos cultivos, temporal e espacialmente, e evidentemente a maior produtividade e produção (SANTOS, 1996).

Assim, algumas pesquisas sobre a influência climática na produtividade agrícola são abordadas, como segue: 
Estudo de Santos (1992) sobre variabilidade e tendência da chuva e sua relação com a produção agrícola mostrou que há redução de produção da cana-deaçúcar em razão da deficiência hídrica, alcançando índices que variaram de $10 \%$ a 40\%. Santos (1975), estudando a influência da distribuição e da quantidade de chuva para a produção de cana-de-açúcar, seleciona anos-padrão e observa a distribuição anual, mensal e diária das chuvas. Considera que o ano-padrão seco pode ser considerado antiprodutivo, o ano-padrão normal produtividade média e o ano padrão úmido como ótimo para a produção dessa cultura.

Segundo Katz (1995), as flutuações anuais na produção estão principalmente ligadas à variabilidade climática, em especial a precipitação pluvial, embora se devam levar em conta os atributos dos solos e a tecnologia adotada.

Borsato e Sant'anna Neto (2002) mostram que as irregularidades na pluviosidade em decorrência do fenômeno El Niño causam variações de redução na produtividade; Guerra e Caramori (2003) também verificaram que a influência do ENOS sobre a precipitação traz impactos positivos e/ou negativos na produtividade das culturas.

Outros estudos (SANTOS, 1996; SANT'ANNA NETO, 1996) sobre a variabilidade das chuvas no estado de São Paulo demonstraram aumento da pluviosidade em torno de $10 \%$ em praticamente todo o estado. Apenas em três unidades climáticas houve redução. Ainda segundo Santos (op. cit.), esse aumento e as mudanças na sazonalidade estão associados à diminuição da participação dos sistemas polares e frontais e a um aumento dos tropicais na gênese pluvial.

Wadsted (1983), avaliando o efeito das variáveis meteorológicas sobre os rendimentos de algumas culturas agrícolas, inclusive a cana-de-açúcar, adverte para os impactos dessas variáveis na produção e na produtividade das culturas e seus reflexos no mercado econômico. Santos (1981), estudando uma associação entre chuva e produtividade na cultura da cana-de-açúcar, verificou que a variabilidade climática é, na maioria das vezes, responsável pela variação na produção, seja ela positiva ou negativa, podendo ocorrer por excesso ou déficit hídrico. Essa autora conclui que totais médios de produção dessa cultura com os totais médios pluviométricos tiveram correlação positiva em média de 0,75 , revelando tendência de aumento nos totais de produção quando se elevam os totais de pluviométricos. 
Para a região Centro-Sul, e especialmente para o estado do Paraná, há duas épocas que favorecem o plantio da cana-de-açúcar: de janeiro a março e de setembro a outubro. Na área de estudo (microrregiões de Londrina e de Paranavaí), o calendário do plantio da cana-de-açúcar, em razão da demanda, principalmente do álcool, juntamente com a oferta de matéria-prima crescente, é bem diversificado (Tabela 3). O plantio de cana-de-açúcar é realizado em todos os meses do ano, embora os índices de plantio mais elevados se concentrem em 7 meses, de janeiro a maio e de setembro a outubro. A colheita tem início em março e vai até dezembro, porém os meses com índices mais altos vão de junho a setembro.

Tabela 3 - Cronograma de distribuição mensal de plantio/rebrota e colheita da cana-de-açúcar no estado do Paraná (SEAB, 2008) e nas microrregiões de Londrina e Paranavaí. Distribuição no Paraná

\begin{tabular}{|c|c|c|c|c|c|c|c|c|c|c|c|c|}
\hline Operação & Jan & Fev & Mar & Abr & Mai & Jun & Jul & Ago & Set & Out & Nov & Dez \\
\hline Plantio/rebrota & $x$ & $x$ & $x$ & $x$ & $x$ & $x$ & $x$ & $\mathrm{x}$ & $x$ & $x$ & $x$ & $x$ \\
\hline Colheita & & & $\mathrm{x}$ & $\mathrm{x}$ & $\mathrm{x}$ & $\mathrm{x}$ & $\mathrm{x}$ & $\mathrm{x}$ & $\mathrm{x}$ & $\mathrm{x}$ & $\mathrm{x}$ & $\mathrm{x}$ \\
\hline \multicolumn{13}{|c|}{ Distribuição na microrregião de Londrina/Cambé } \\
\hline Plantio/rebrota & & & $\mathrm{x}$ & $\mathrm{x}$ & $\mathrm{x}$ & $\mathrm{x}$ & & & $\mathrm{x}$ & $\mathrm{x}$ & & \\
\hline Colheita & & & & $\mathrm{x}$ & $\mathrm{x}$ & $\mathrm{x}$ & $\mathrm{x}$ & $\mathrm{x}$ & $\mathrm{x}$ & $\mathrm{x}$ & $\mathrm{x}$ & $\mathrm{x}$ \\
\hline \multicolumn{13}{|c|}{ Distribuição na microrregião de Paranavaí/Mirador } \\
\hline Plantio/rebrota & & & $\mathrm{x}$ & $\mathrm{x}$ & $\mathrm{x}$ & $\mathrm{x}$ & $\mathrm{x}$ & $\mathrm{x}$ & $\mathrm{x}$ & $\mathrm{x}$ & $\mathrm{x}$ & $\mathrm{x}$ \\
\hline Colheita & & & & $\mathrm{x}$ & $\mathrm{x}$ & $\mathrm{x}$ & $\mathrm{x}$ & $\mathrm{x}$ & $\mathrm{x}$ & $\mathrm{x}$ & $\mathrm{x}$ & $\mathrm{x}$ \\
\hline
\end{tabular}

Fonte: COROL (Cooperativa de Cambé); COOPCANA (Cooperativa de Cana-de-açúcar, São Jorge do Ivaí, PR).

O período de janeiro a março é a época que oferece condições mais adequadas de crescimento e desenvolvimento. Assim, a cana-de-açúcar inicia seu ciclo nos meses com condições boas de umidade e temperatura, janeiro a março, permanecendo em repouso por cinco meses, de abril a agosto. Esse período de repouso é necessário para que haja redução ou interrupção do crescimento da planta, para que os produtos assimilados sejam armazenados na haste, em vez de serem utilizados no processo de crescimento.

Os fatores que têm maior influência nesse repouso são baixa temperatura e deficiência de umidade. Na sequência, de setembro a abril, a planta vegeta com toda a intensidade, para então amadurecer nos meses de inverno, completando 18 meses de idade. Ou seja, um ano e seis meses para fechar seu ciclo vegetativo, razão pela qual é denominada cana-de-ano e meio. A segunda época de plantio, 
que acontece de setembro a outubro, tem ciclo de 12 meses, por isso é denominada cana-de-ano (Figura 5). Seu cultivo só se justifica quando se precisa de matériaprima a curto prazo, pois o rendimento, em relação à cana-de-ano e meio, é menor (Tabela 4).

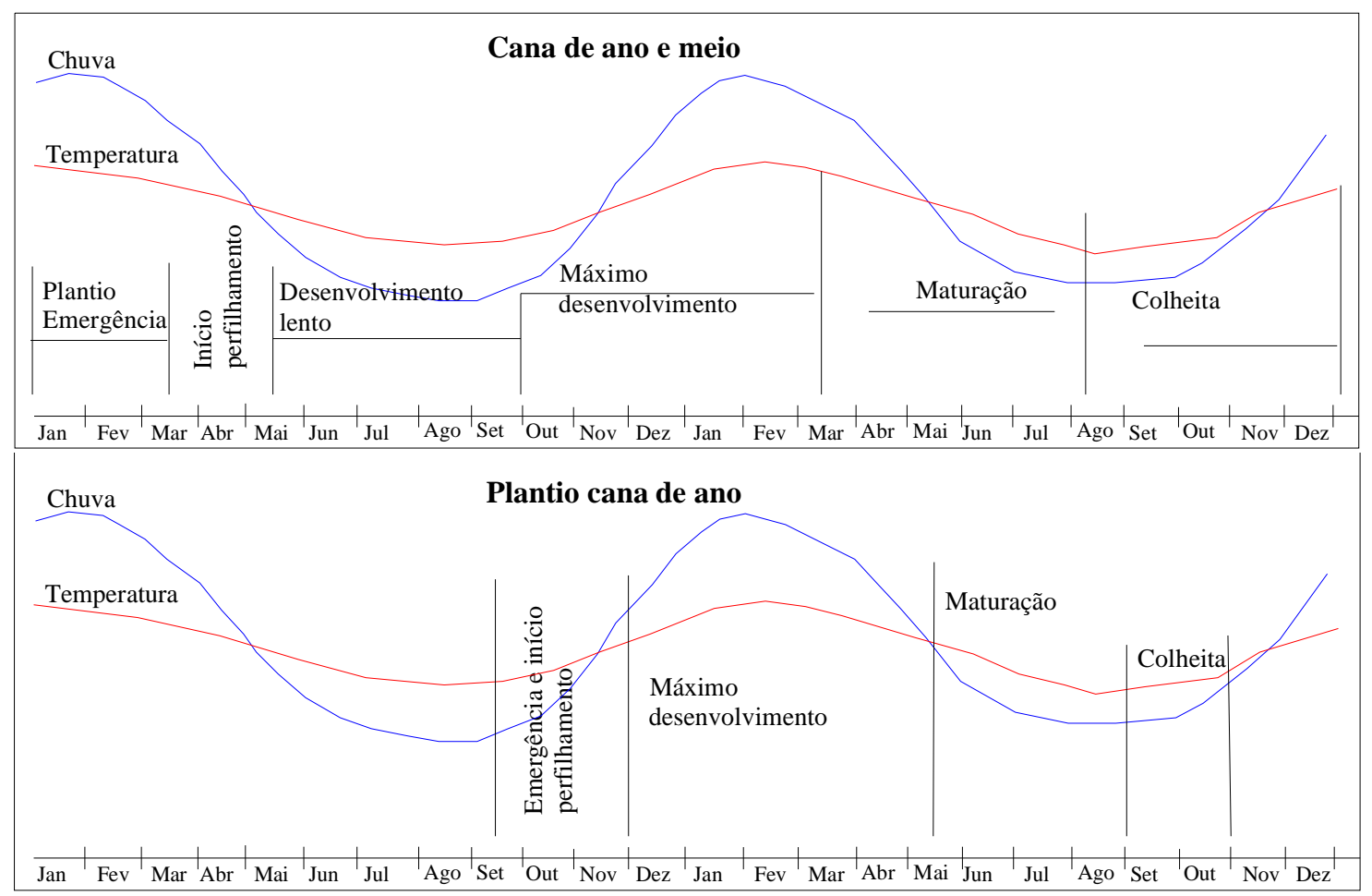

Figura 5 - Ciclo da cultura da cana-de-açúcar para a região Centro-Sul do Brasil.

Fonte: Rodrigues (1995).

A cana-de-açúcar é denominada cana-planta até a sua primeira colheita; depois, devido à rebrota, passa a ser chamada cana-soca, e as colheitas subsequentes são chamadas ressocas. As rebrotas da cana-de-açúcar sofrem em torno de 4 a 5 cortes, quando então a lavoura é renovada com uma cana-de-ano ou cana-de-ano e meio (RUDORFF, 1985). Esse processo de renovação da lavoura se dá porque a cada ano a cultura vai reduzindo sua produtividade (Figura 6). Outro fator que também influencia diretamente na produtividade é o tempo de permanência da cana-planta no campo em sua primeira colheita. 


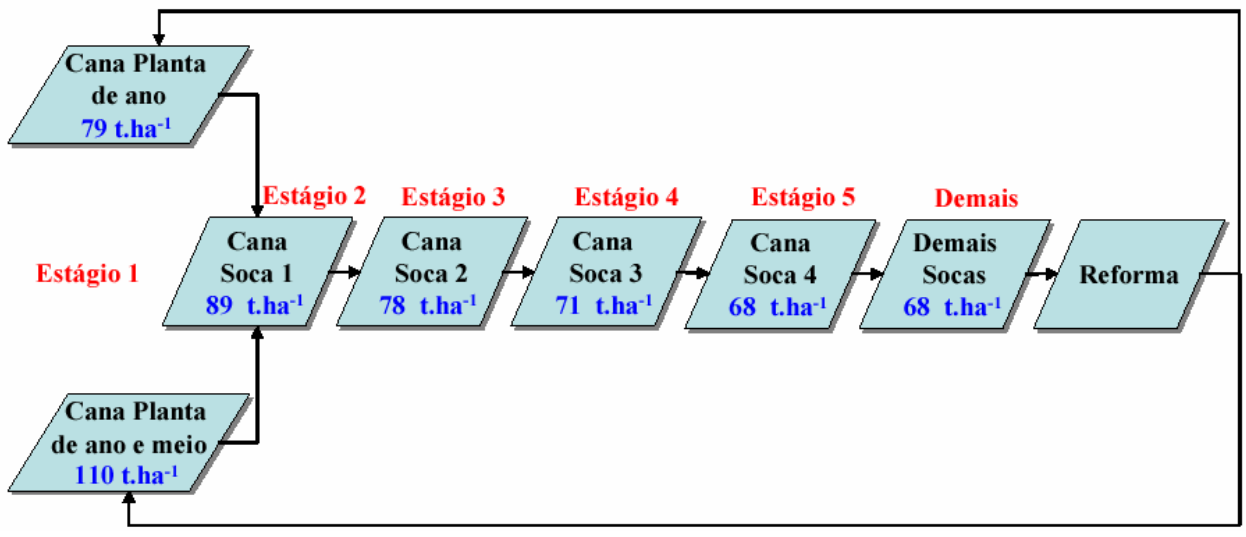

Figura 6 - Exemplo ilustrativo de estágios de corte e valores médio de produtividade da cana-deaçúcar.

Fonte: Sagawara (2007).

Tabela 4 - Período de duração para cada fase de desenvolvimento da cultura da cana-de-açúcar, Coeficiente de cultura (Kc) e Índice de Área Foliar (DOORENBOS; PRUITT, 1975).

\begin{tabular}{|c|c|c|c|c|c|c|}
\hline \multicolumn{2}{|c|}{ Idade (meses) } & \multirow{2}{*}{ IAF (\%) } & \multicolumn{3}{|c|}{ Valores Kc } & \multirow{3}{*}{$\begin{array}{l}\text { Fases da cultura } \\
\text { Fase inicial de } \\
\text { crescimento lento - } \\
\text { entre o plantio e } 200 \\
\text { dias após }\end{array}$} \\
\hline $\begin{array}{l}\text { Cana- } \\
\text { Planta } \\
\text { de ano e } \\
\text { meio }\end{array}$ & $\begin{array}{l}\text { Cana- } \\
\text { Planta/ } \\
\text { Soca }\end{array}$ & & Máx & Mín & Méd & \\
\hline $0-2$ & $0-1$ & $\begin{array}{l}\text { Do plantio até } 0,25 \text { de } \\
\text { cobertura do solo* }\end{array}$ & 0,60 & 0,40 & 0,50 & \\
\hline $2-3$ & $1-2$ & $\begin{array}{l}\text { De } 0,25 \text { a } 0,50 \text { de cobertura } \\
\text { do solo* }\end{array}$ & 0,85 & 0,75 & 0,80 & \\
\hline $3-4$ & $2-3$ & $\begin{array}{l}\text { De } 0,50 \text { a } 75 \text { de cobertura } \\
\text { do solo* }\end{array}$ & 1,00 & 0,90 & 0,95 & \\
\hline $4-7$ & $3-4$ & 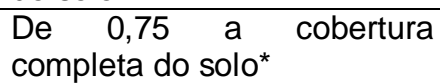 & 1,20 & 1,00 & 1,10 & \\
\hline $7-14$ & $4-9$ & Utilização máxima $^{\#}$ & 1,30 & 1,05 & 1,20 & Fase de crescimento \\
\hline $14-16$ & $9-10$ & Início da maturação+ $^{+}$ & 1,05 & 0,80 & 0,95 & $\begin{array}{l}\text { rápido - entre } 200 \text { e } \\
400 \text { dias após }\end{array}$ \\
\hline $16-18$ & $10-12$ & Maturação $^{+}$ & 0,75 & 0,60 & 0,70 & $\begin{array}{l}\text { Fase final - entre } 400 \\
\text { e } 500 \text { dias após }\end{array}$ \\
\hline
\end{tabular}

* Primeiro estádio: estabelecimento da cultura seguido período vegetativo

"Segundo estádio: formação da produção

+Terceiro estádio: Maturação

Com relação ainda ao consumo de água pela planta da cana-de-açúcar, pode-se dizer que a umidade é o principal fator causador da variabilidade anual de sua produção e produtividade (TERAMOTO, 2003) ou mesmo interanual da produção e da produtividade agrícola. Os totais pluviométricos anuais exigidos encontrados na literatura são: de acordo com Cuenca e Nazário (2005), para os 
climas tropicais e subtropicais a cana-de-açúcar melhor se adapta a nível pluviométrico de um mínimo de 1.200mm; segundo Doorenbos e Kassam (1994), a necessidade hídrica da cana-de-açúcar é de $1.500 \mathrm{~mm}$ a $2.500 \mathrm{~mm}$ por ciclo vegetativo; de acordo com Oliveira (2001), um mínimo de $850 \mathrm{~mm}$ no período vegetativo é suficiente para um bom crescimento da cana-de-açúcar; e Zink (1978) considera que a precipitação em torno de $1.200 \mathrm{~mm}$ anuais é suficiente para o bom desenvolvimento da cana-de-açúcar, necessitando de mais água nos primeiros meses de crescimento e posteriormente de um período seco para a maturação.

Essa água disponibilizada no solo governa a produção vegetal, de modo que sua redução ou excesso podem afetar, de maneira decisiva, o desenvolvimento das plantas, alterando a absorção dos nutrientes e da própria água (REICHARDT, 1996). Um estresse hídrico, por exemplo, durante o desenvolvimento da cultura da canade-açúcar, leva a uma restrição dos processos fisiológicos, como a divisão celular e sua elongação. Tais fatores causariam danos como a diminuição na taxa de acúmulo de massa seca, na taxa de elongação da cultura e no Índice de Área Foliar (INMAN-BAMBER, 2004).

Segundo Scardua; Rosenfeld (1987), o consumo também varia em razão do estágio fisiológico, do ciclo da cultura (cana-planta ou cana-soca), das condições climáticas, da água disponível no solo, entre outros fatores. Assim, na interação do sistema atmosfera-solo-planta, há certa quantidade de água que entra e sai de cada um desses componentes, fazendo com que a água armazenada no solo esteja em constante variação (DOORENBOS; KASSAM, 1994). A cana-de-açúcar pode ser cultivada tanto em solos arenosos (com limitações à baixa capacidade de armazenamento de água e alta taxa de perda de nutrientes por lixiviação) quanto em solos muito argilosos (drenagem mais lenta, propiciando menor aeração da zona radicular e também alta suscetibilidade à compactação, que é limitante à penetração das raízes) (KOFLER; DONZELI, 1987).

O entendimento fisiológico da cana-de-açúcar, como um todo, depende também do conhecimento de cada estádio do seu desenvolvimento. Para cada fase a ela apresenta diferentes exigências climáticas, sendo umas mais exigentes que outras. De acordo com Doorenbos e Kassan (1994), os períodos de desenvolvimento são: estabelecimento, período vegetativo, formação da colheita e maturação, ou seja, germinação, perfilhamento, desenvolvimento e maturação 
(Figura 7). Como exemplo dessas fases cita-se que, após a fase de crescimento, para que haja boa produção de sacarose nos colmos, há necessidade de um período de estresse (hídrico ou térmico) para cessar o crescimento vegetativo e começar a fase de maturação (BRAY, 1980).

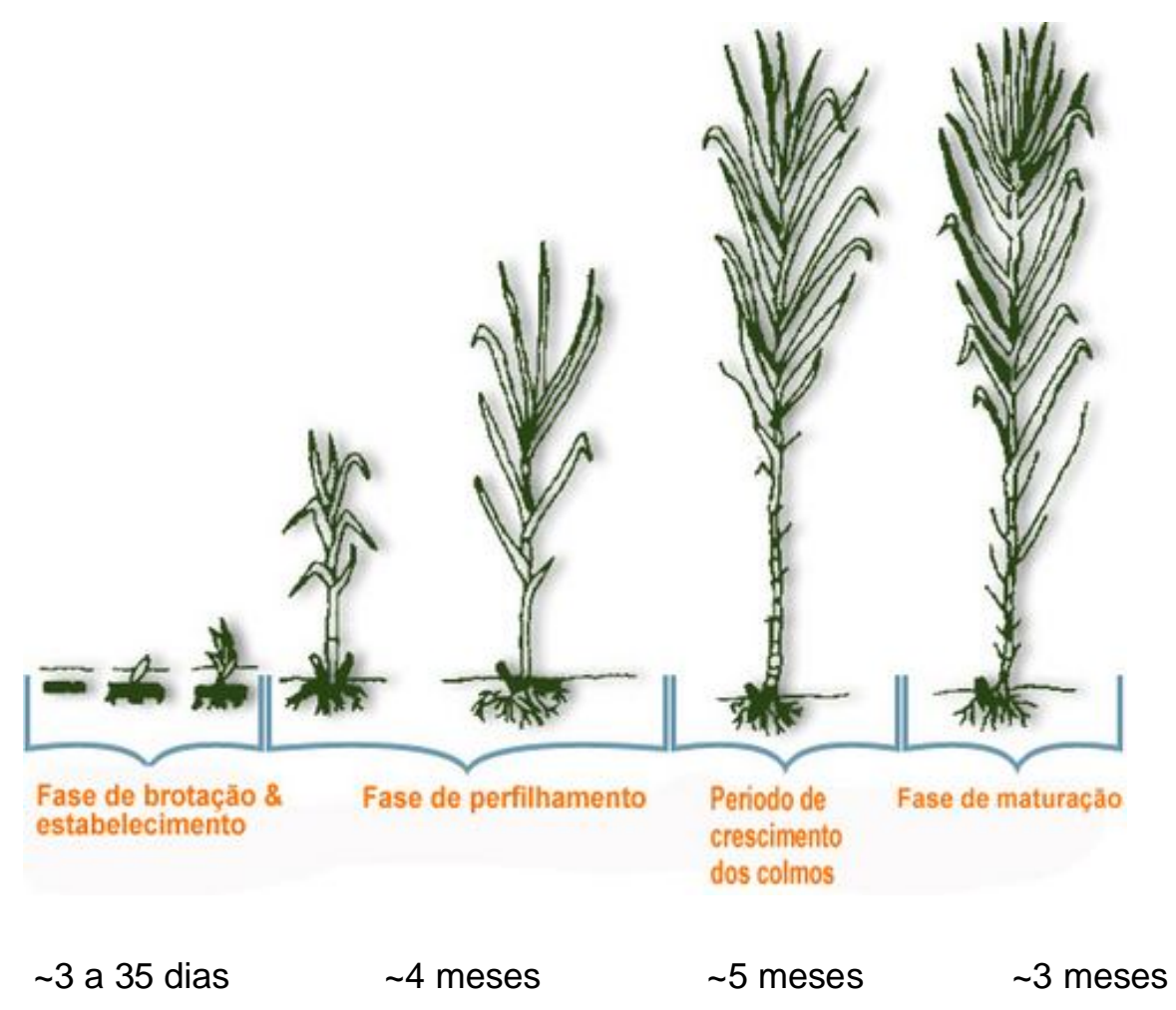

Figura 7 - Fases de desenvolvimento da cultura da cana-de-açúcar.

Fonte: <http://www.sugarcanecrops.com/p/growth_morphology/propagation/> .

Ainda sobre o período de desenvolvimento, acrescente-se que este se processa em três fases: a fase inicial de crescimento lento, a fase de crescimento rápido e a fase final de crescimento lento (MACHADO, 1987).

$\mathrm{Na}$ fase inicial de crescimento lento, tem-se a brotação, fase de estabelecimento e perfilhamento. A brotação se inicia do sétimo ao décimo dia após o plantio, com duração aproximada de 30-35 dias. Condições de solo úmido e calor asseguram brotação rápida. A fase perfilhamento, e por perfilhamento entende-se o número de talos necessários para uma boa produção, começa ao redor de 40 dias depois do plantio e pode durar até 120 dias. Vários fatores, tais como luz, 
temperatura, umidade do solo, influenciam essa fase. Temperatura ao redor de $30^{\circ} \mathrm{C}$ é considerada ideal para o perfilhamento. Temperatura abaixo de $20^{\circ} \mathrm{C}$ retarda 0 perfilhamento

$\mathrm{Na}$ fase de crescimento rápido, tem-se a fase de crescimento dos colmos, florescimento e frutificação. A fase de crescimento dos colmos começa a partir de 120 dias depois do plantio e dura até 270 dias em um cultivo de 12 meses. Durante o período anterior a essa fase de perfilhamento, ocorre uma estabilização. Essa é a fase mais importante do cultivo, quando ocorre a formação e alongamento e assim resulta na produção. Calor, umidade e condições de intensidade luminosa favorecem um melhor alongamento da cana-de-açúcar. Falta de umidade reduz a extensão dos entrenós. Uma temperatura ao redor de $30^{\circ} \mathrm{C}$ com uma umidade ao redor de $80 \%$ é mais condutiva para um melhor cultivo.

$\mathrm{Na}$ fase final de crescimento lento tem-se a fase de maturação. Esta, em um cultivo de 12 meses, dura ao redor de 3 meses, começando de 270 a 360 dias. Essa fase exige um período de estresse hídrico ou térmico para o seu bom desempenho. Conforme a maturação avança, açúcares simples (monossacarídeo, frutose e glicose) são convertidos em cana-de-açúcar (sacarose, um dissacarídeo). A síntese de açúcar e o acúmulo rápido de açúcar acontecem durante essa fase, e o crescimento vegetativo é reduzido (SUGARCANECROPS, 2008).

A princípio o processo se inicia com o plantio da cana-de-açúcar, que pode ser efetuado utilizando-se desde toletes de uma gema até a cana inteira (CASTRO et al., 2001). Geralmente, plantam-se toletes com 3 entrenós. Os toletes são colocados em sulcos com $25 \mathrm{~cm}$ a $30 \mathrm{~cm}$ de profundidade e cobertos com uma camada de terra de $2,5 \mathrm{~cm}$ a $5 \mathrm{~cm}$. Certas condições ambientais afetam a emergência das gemas. As melhores temperaturas para a emergência das gemas situam-se entre $27^{\circ} \mathrm{C}$ e $32^{\circ} \mathrm{C}$, sendo que temperaturas abaixo de $20^{\circ} \mathrm{C}$ e acima de $35^{\circ} \mathrm{C}$ causam problemas na emergência, (CASAGRANDE, 1991).

A transição de raízes ramificadas para raízes de fixação inicia-se em torno de 20 dias após a emergência. Aos 90 dias após o plantio a cana-de-açúcar depende exclusivamente das raízes dos perfilhos, sendo que as raízes de fixação perdem sua função. Nesse momento, todo o sistema radicial encontra-se distribuído nos primeiros $30 \mathrm{~cm}$ de profundidade (BACCHI, 1985; CASAGRANDE, 1991). As raízes 
do colmo, mais grossas, penetram lentamente no solo, inicialmente, para aumentar a velocidade com o crescimento, declinando posteriormente. Com 2 a 3 meses do plantio, o sistema radicial encontra-se bem desenvolvido, (CASTRO et al., 2001) (Figura 8).

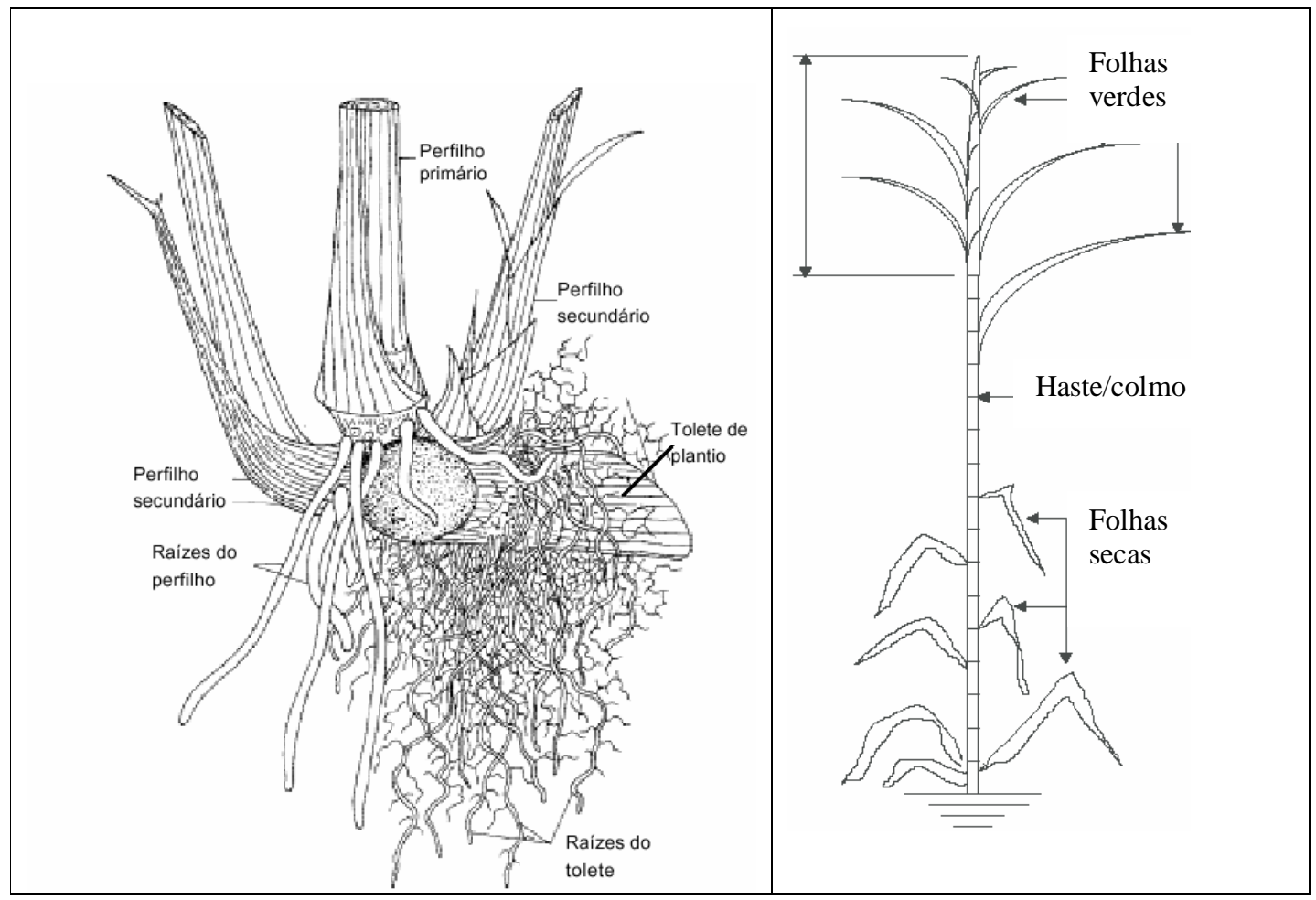

Figura 8 - Partes de uma planta de cana-de-açúcar em crescimento subaéreo e aéreo. Fonte: Blackburn (1984).

Dessa forma, o processo inicial de crescimento da planta da cana-de-açúcar se dá, em boas condições de umidade, pelo intumescimento da gema e dos primórdios radiculares localizados na região do nó, quando o broto se desenvolve em direção à superfície. Simultaneamente, surgem as raízes do rebolo, chamadas raízes de fixação, e intensifica-se o consumo de reservas nutricionais do rebolo. $A$ gema apical assume o crescimento em altura, que resultará em uma sucessão de nós e internódios, formando o colmo da planta (Figura 7).

De duas a quatro semanas após a emergência surgem raízes fibrosas na base do perfilho primário (emissão de colmo), com a função de fixá-lo ao solo e 
fornecer água e nutrientes. Cada um dos perfilhos comporta-se como uma planta independente e autônoma; tem órgãos próprios. como raízes, colmos e folhas, mas todos aqueles que compõem a touceira continuam tendo ligações entre si e podem eventualmente trocar alguns nutrientes e água. O perfilhamento e a sobrevivência dos perfilhos até a maturidade são determinados pelo genótipo, porém influenciados pelo clima, solo e condições nutricionais. $O$ crescimento em altura do perfilho primário promove a expansão das primeiras folhas, aumentando a capacidade e a atividade fotossintética da planta.

O perfilhamento pode ocorrer até 4 meses após o plantio. Posteriormente se verifica decréscimo nos números de novos perfilhos, em decorrência da competição natural estabelecida pelo fechamento do dossel, e durante o seu fechamento ocorre superprodução de colmos. Destes, $50 \%$ senescem e morrem; seu estabelecimento definitivo ocorre cerca de 9 meses após o plantio. Nessa fase ocorre intenso consumo das reservas nutricionais do rebolo (CASTRO; CHRISTOFFOLETI, 2005).

Diante dessas leituras, pode-se dizer que todos os parâmetros climáticos abordados têm um grau de importância intrínseca para a cultura estudada, embora cada elemento do clima aja de forma mais ou menos intensa, de acordo com as fases fenológicas e as necessidades fisiológicas da planta. Portanto, o entendimento da variabilidade climática é de fundamental importância, em especial na cultura da cana-de-açúcar. 


\section{3 - MATERIAIS E MÉTODOS}

\section{1 - Fluxograma de orientação metodológica}

Organizou-se um fluxograma com a intenção de sintetizar e destacar as principais etapas e procedimentos realizados na elaboração deste trabalho de pesquisa (Figura 9). Procedimentos esses explicados ao longo da redação.

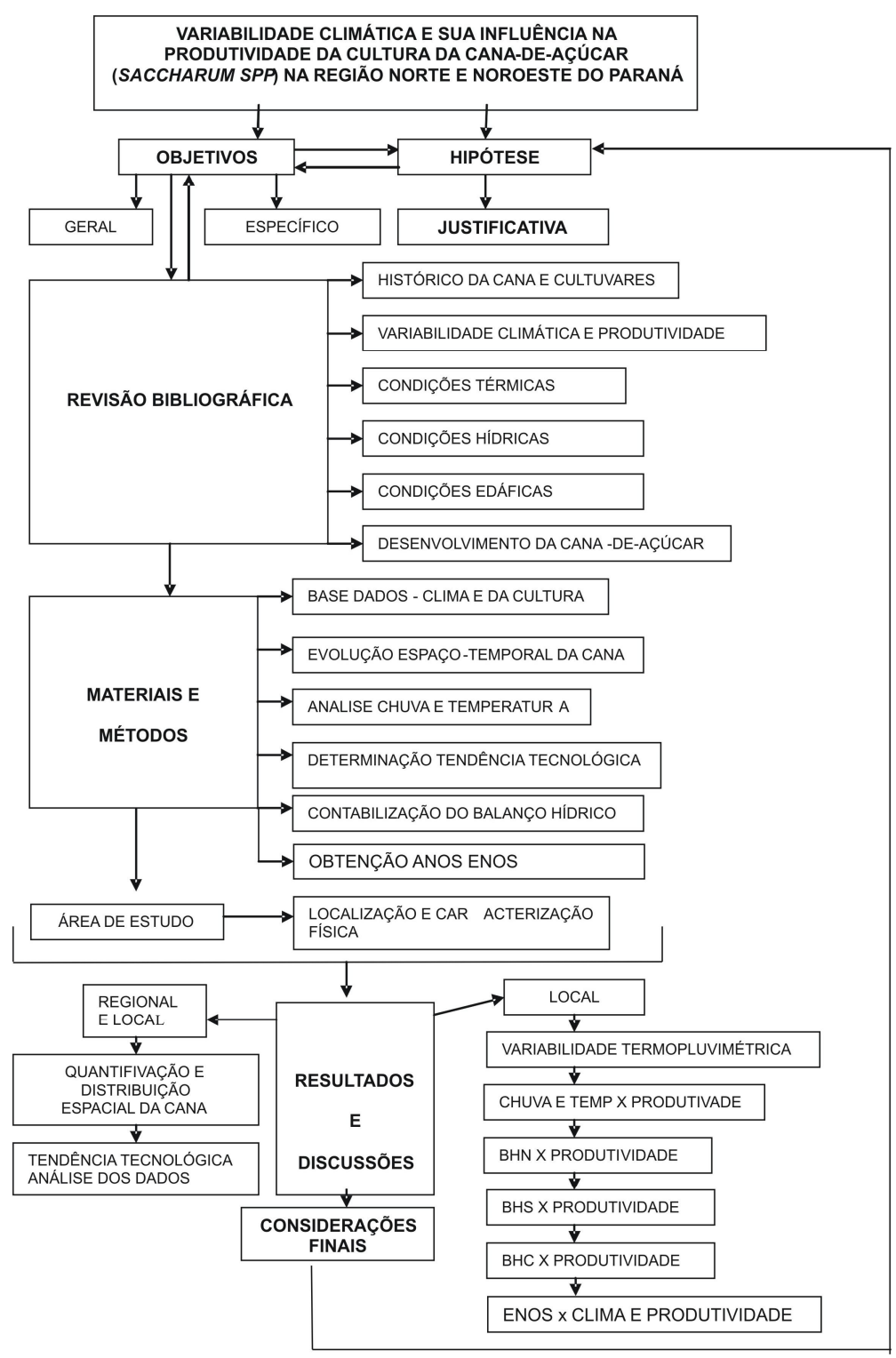

Figura 9 - Fluxograma de orientação metodológica norteador do desenvolver da tese.

BHN (Balanço Hídrico Normal), BHS (Balanço Hídrico Sequêncial), BHC (Balanço Hídrico de Cultura), ENOS (El Niño Oscilação Sul).

Org.: Domingues, I.A.S. (2010). 


\section{2 - Localização geográfica e caracterização física da área de estudo}

\subsection{1 - Contexto geográfico da área}

A área de estudo compreende dois municípios paranaenses. O município de Mirador está na latitude de 231'ㄹ' metros; o município de Cambé localiza-se na latitude de 231ㅡ'32"S, longitude de 5116'41' W e altitude de 650 metros. Estão inseridos, respectivamente, nas denominadas mesorregiões Noroeste e Norte Central do Paraná (Figura 10).

O estado do Paraná faz parte da região Sul do Brasil e ocupa uma área de 199.314,94km². Esse estado está inserido, segundo Maack (2002), entre os paralelos de 2229'30"S, na cachoeira Saran Grande, no rio Paranapanema, e

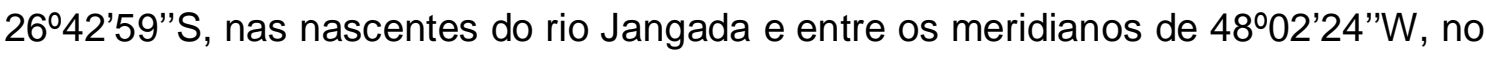
rio Arapira, e 5437'38'W, na foz do rio Iguaçu (Figura 10).

O estado do Paraná faz limites, ao norte, com o estado de São Paulo, ao longo do rio Paranapanema; ao sul percorre a divisa com o estado de Santa Catarina e com a Argentina, desde as nascentes do rio Santo Antônio até a sua confluência com o rio Iguaçu; a leste com a orla do oceano Atlântico, numa extensão de $107 \mathrm{~km}$; a oeste com o Paraguai e o Mato Grosso do Sul, até a desembocadura do rio Paranapanema.

O estado é composto por 399 municípios, agrupados em 10 mesorregiões (Figura 11) e 39 microrregiões (FUNDAÇÃO IBGE, 1996). Essa divisão se deve à interrelação de variáveis socioeconômicas, agrícolas e de recursos naturais que permitem agregar os 399 municípios paranaenses dentro de áreas homogêneas que facilitam estudos e comparações. O número de municípios que compõem as microrregiões varia de 2 (microrregião geográfica Lapa - mesorregião metropolitana de Curitiba) a 29 (microrregião geográfica de Paranavaí - mesorregião Noroeste). 


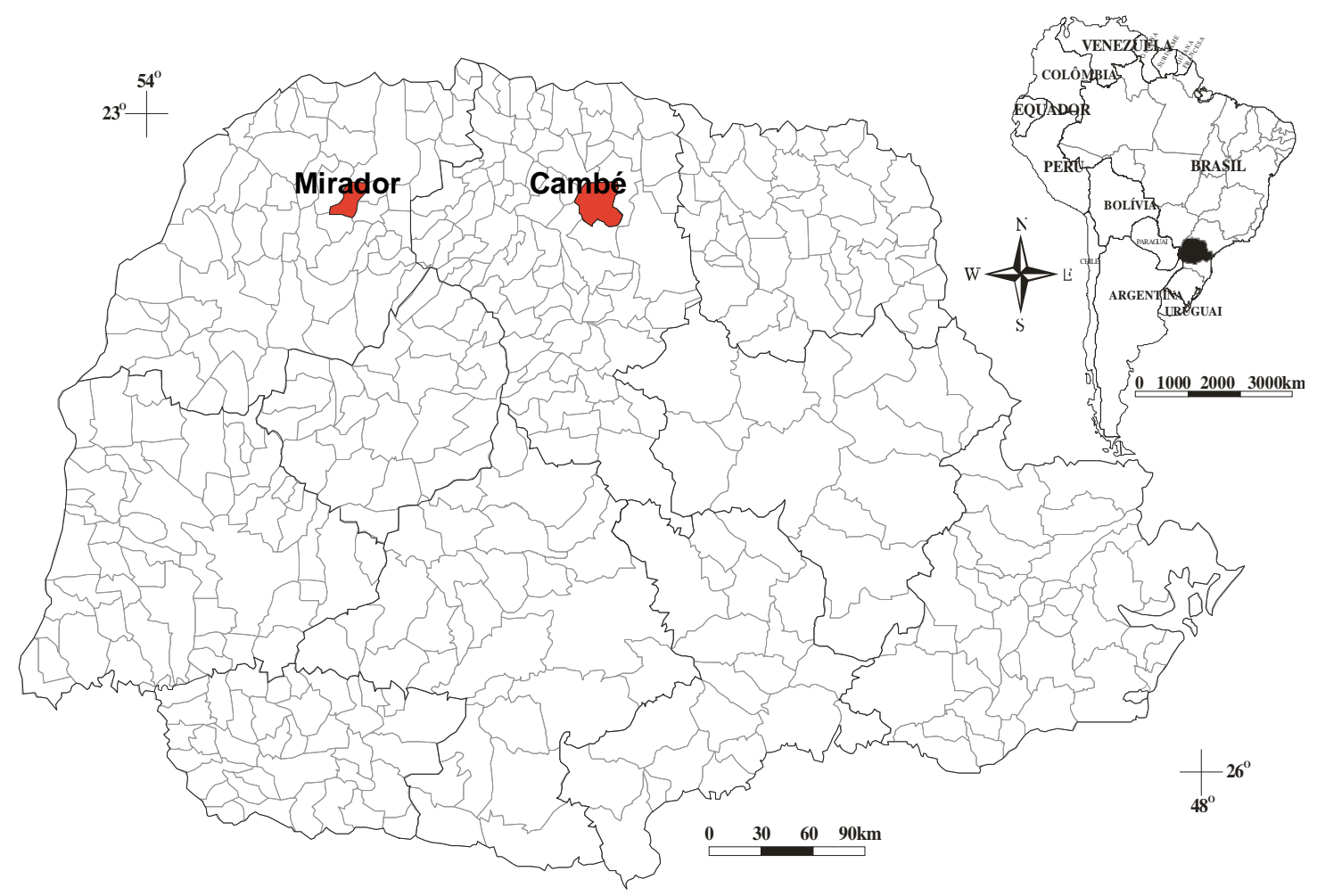

Figura 10 - Mapa de localização do estado do Paraná, destacando os municípios de Mirador no Noroeste, e Cambe, no Norte Central. Org.: Domingues, I.A.S. (2008).

A mesorregião Noroeste paranaense, com área de $24,489 \mathrm{~km}^{2}$, congrega 61 municípios e é composta por 3 microrregiões: microrregião geográfica de Paranavaí; microrregião geográfica de Umuarama; microrregião geográfica de Cianorte.

A mesorregião Norte Central, com área de $24.556 \mathrm{~km}^{2}$, perfaz um total de 8 microrregiões: Astorga, Porecatu, Floraí, Maringá, Apucarana, Londrina, Faxinal e Ivaiporã. Juntas, totalizam 79 municípios. 


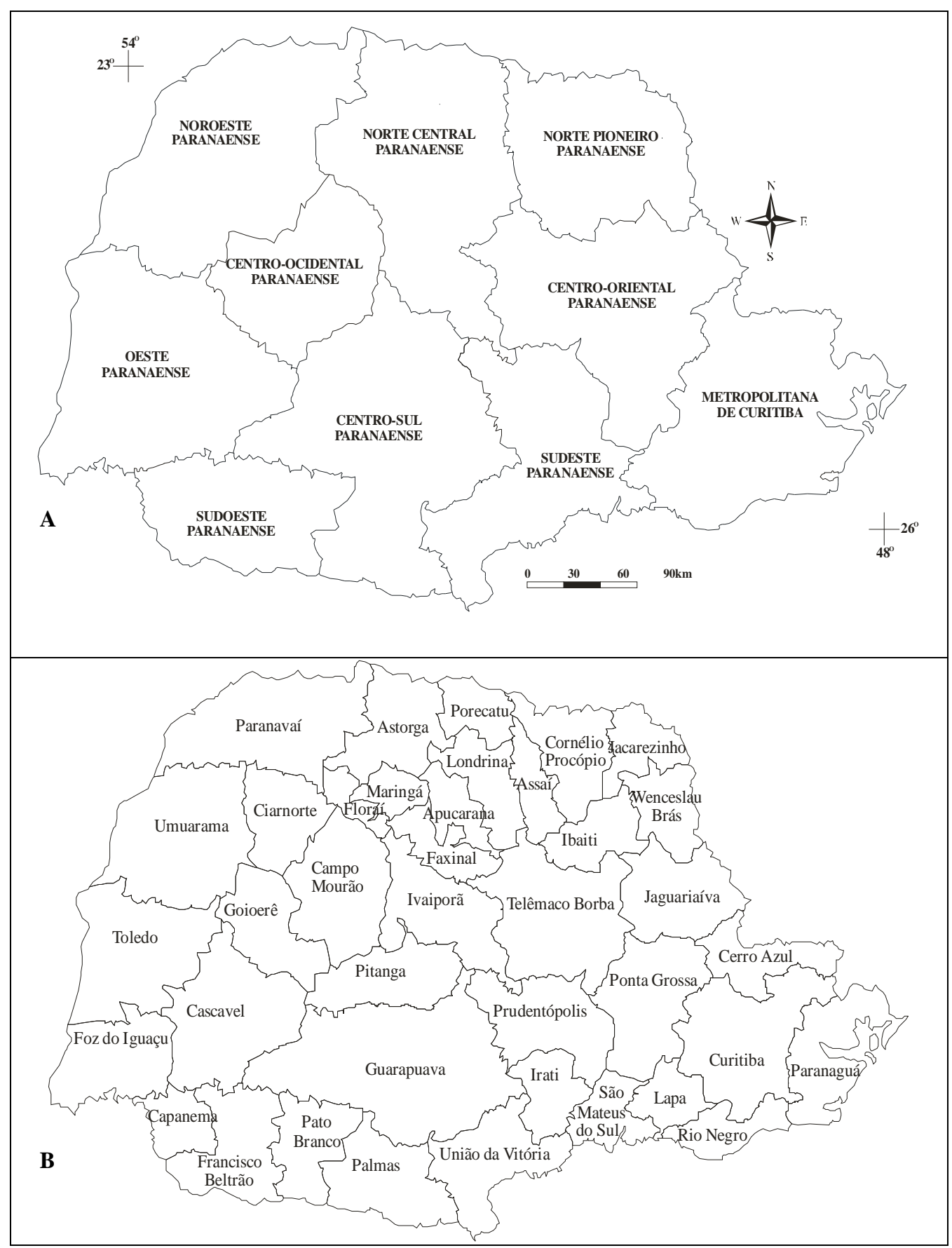

Figura 11 - Divisão do estado do Paraná em (A) 10 mesorregiões e (B) 39 microrregiões (Mod. IBGE, 1996).

Segundo o IPARDES (2004), a ocupação da mesorregião Noroeste paranaense deu-se em decorrência da expansão da fronteira agrícola no estado, a cafeicultura, embora na época a prática agrícola para culturas anuais fosse 
inviabilizada devido à suscetibilidade do solo, "Arenito Caiuá" (Formação Caiuá), à erosão. Dentre as atividades mais desenvolvidas na região tem-se a pecuária.

De acordo com esse instituto, as atividades agropecuárias mantêm participação expressiva na ocupação da mão de obra regional. Essas atividades apresentam, comparativamente a outras mesorregiões, indicadores de produtividade mais baixos, e estão estruturadas principalmente em torno da pecuária bovina.

$\mathrm{Na}$ década de 1990, essa mesorregião se constituiu em fronteira para a expansão da soja e do milho, em um sistema que se vale da reforma de pastagens e dos avanços tecnológicos observados na área de manejo e conservação de solos. Além da expansão de commodities, observou-se crescimento de produtos direcionados à indústria, como a cana, a mandioca e aves, além da destacada produção estadual de casulos do bicho-da-seda, café e fruticultura (abacaxi, laranja e manga).

Em termos industriais, concentra as atividades de beneficiamento da mandioca e de polo sucroalcooleiro do estado. Além disso, destaque-se o forte avanço na área de confecção, na qual a região se distingue como referência nacional.

Não diferentemente, a mesorregião Norte Central iniciou seu desenvolvimento com a cultura do café e posteriormente com a expansão da pecuária e agroindústria. Tem destaque na produção de soja, milho, cana-de-açúcar, têxtil etc. Essa mesorregião se distingue como o maior parque agroindustrial do estado.

\subsection{2 - Aspectos geológicos e geomorfológicos}

Segundo a MINEROPAR (2010), o estado do Paraná é constituído por vários tipos de rochas: no setor Leste predominam rochas cristalinas, mais antigas, enquanto no setor Oeste desenvolvem-se as sedimentares, mais recentes. As rochas ígneas e metamórficas formam o embasamento ou Escudo Paranaense, expondo rochas com idades superiores a 570 milhões de anos. Para oeste as rochas cristalinas estão recobertas pelas rochas sedimentares, de idade paleozóica, 
da bacia sedimentar do Paraná, e pela sequência de derrames da Formação Serra Geral. Sobre os derrames ocorrem sedimentos do Grupo Bauru, próximo à calha do rio Paraná. Materiais sedimentares mais recentes recobrem parcialmente as rochas, tanto do escudo como da bacia sedimentar do Paraná (Figura 12).
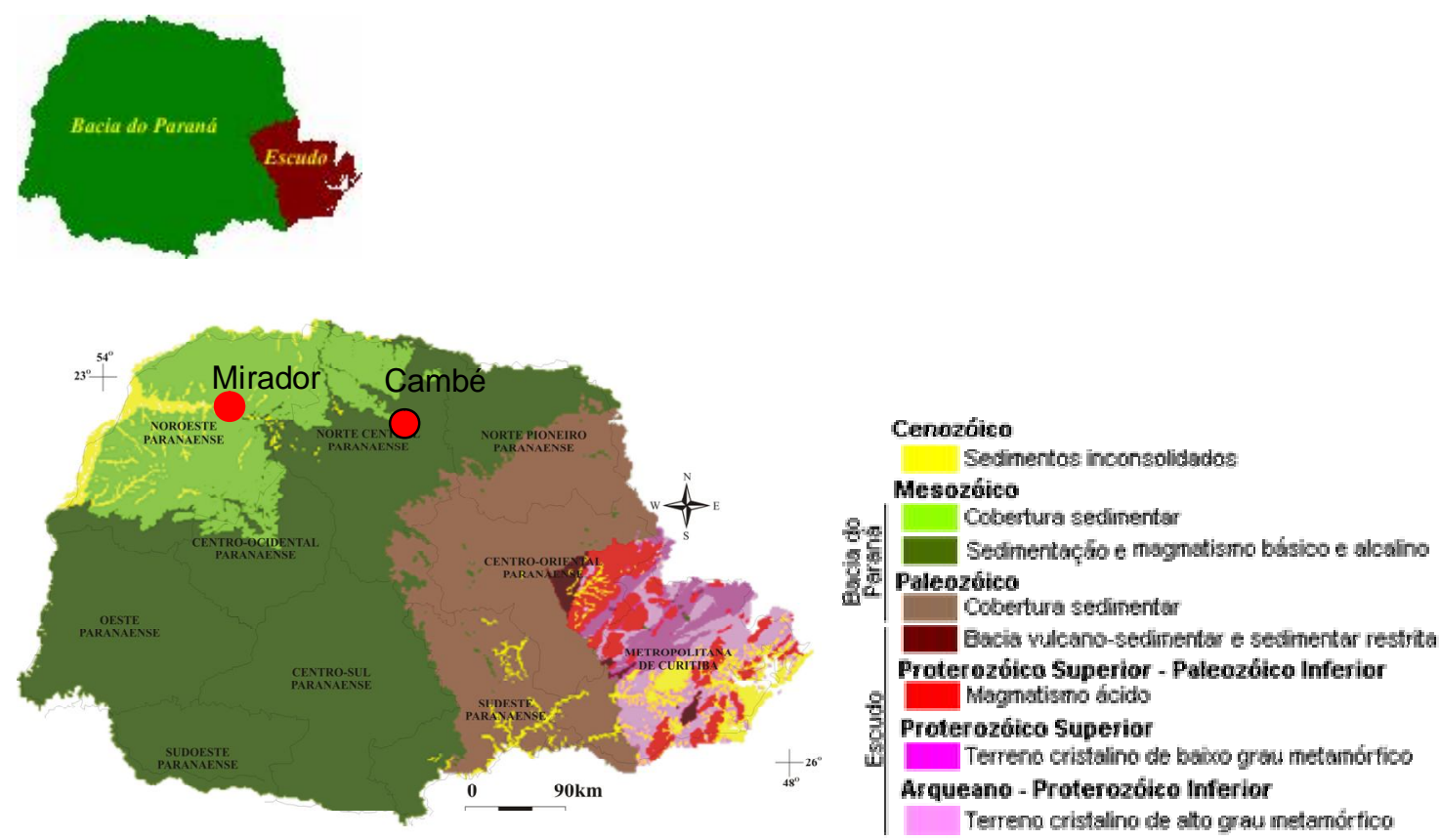

WNW

SE

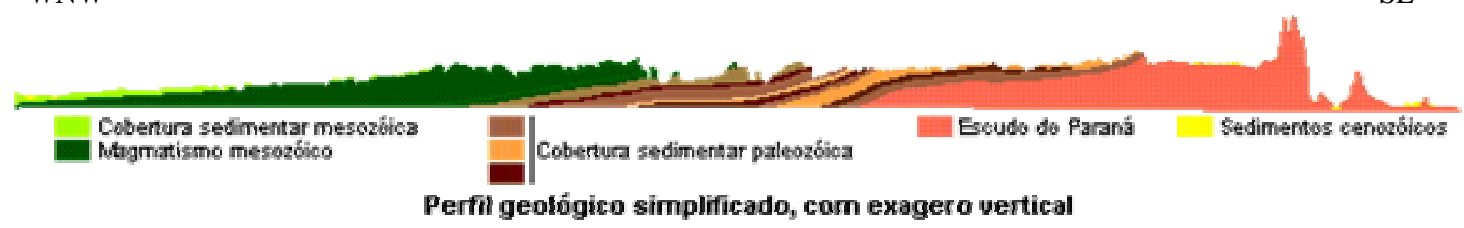

Figura 12 - Mapa geológico do Paraná ilustrando perfil geológico. (Mod. Mineropar, 2001).

Maack (1968) divide o estado do Paraná em 5 unidades geomorfológicas, assim denominadas: Planície Litorânea ou Costeira, Serra do Mar, Primeiro Planalto Paranaense, Segundo Planalto Paranaense e Terceiro Planalto Paranaense, denominado por Santos et al. (2006) como Terceiro Planalto Basáltico e Terceiro Planalto Arenítico (Figura 13). 
A Planície Litorânea ou Costeira é formada por uma faixa que se estende entre a Serra do Mar e o oceano Atlântico, constituída predominantemente por sedimentos inconsolidados recentes.

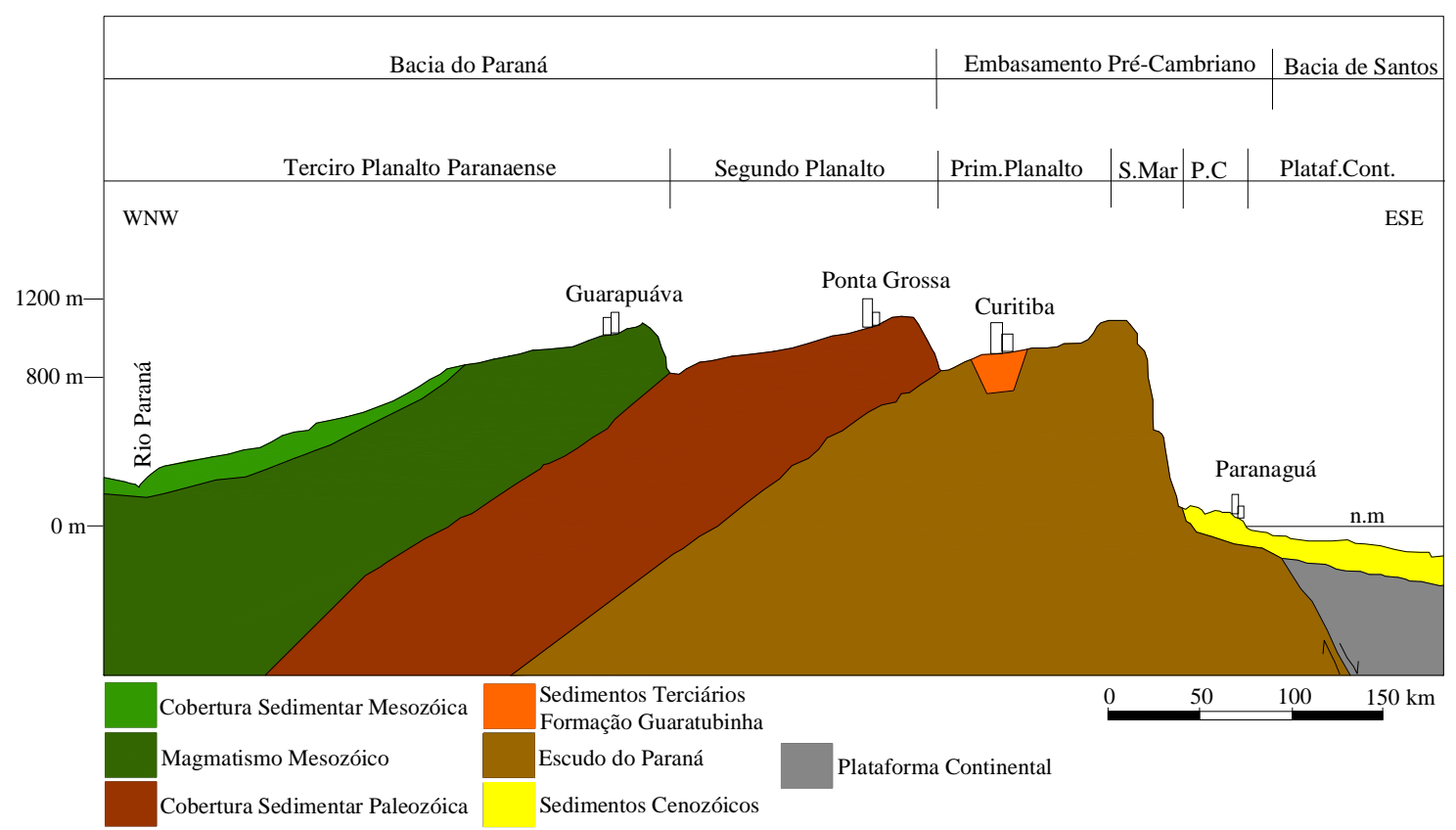

Figura 13 - Perfil geológico-geomorfológico do estado do Paraná ilustrando as 5 grandes paisagens naturais, segundo Maack. (P.C - Planície Costeira). (Mod. de MELO; MENEGUZZO, 2001).

A unidade Serra do Mar é formada por morros isolados, cadeia de montanhas e as escarpas da Serra do Mar, desenvolvendo as maiores altitudes do estado. Nessa unidade predominam rochas ígneas, metamórficas e metassedimentares antigas, com mais de 3 bilhões de anos. Na Serra do Mar afloram as rochas com idades entre o Arqueano e início do Paleozóico. São rochas muito resistentes ao intemperismo, sendo responsáveis pelo forte relevo e altas declividades da paisagem.

O Primeiro Planalto Paranaense desenvolve-se a partir da Serra do Mar até a escarpa devoniana (serra de São Luiz do Purunã). Para oeste, o escudo é recoberto por uma espessa sequência de rochas sedimentares e vulcânicas pertencentes à bacia sedimentar do Paraná. Essa sequência começa na escarpa da Serrinha (serra de São Luís do Purunã), chegando até a serra da Boa Esperança, onde começa o 
Terceiro Planalto Paranaense. Sua formação teve início no Siluriano $(\approx 443$ milhões de anos), terminando no Período Cretáceo ( $\approx 80$ milhões de anos). Inicialmente, a posição dos continentes era muito diferente da atual; a América do Sul ligava-se à África, formando o megacontinente Gondwana (ALMEIDA, 1983; MAACK, 2002).

As escarpas ou cuestas de camadas formadas por capas de sedimentos, pertencentes à bacia sedimentar do Paraná e que mergulham suavemente para oeste e noroeste, estendem-se através do estado, e com a forma de arco constituem o Segundo Planalto Paranaense. A serra de São Luís do Purunã é o primeiro dos grandes degraus de escarpa ou cuesta formado por sedimentos paleozóicos e arenitos devonianos, e é também denominada escarpa devoniana. O segundo grande degrau de escarpa ou cuesta separa a região dos sedimentos paleozóicos da sequência de derrames vulcânicos de idade mesozóica e é conhecido como escarpa Triássico-Jurássica ou serra da Boa Esperança, inicio do Terceiro Planalto Paranaense.

Nesse contexto geológico-geomorfológico está inserida a área de estudo, na bacia sedimentar do Paraná, no Terceiro Planalto Paranaense. A evolução dessa bacia durou mais de 350 milhões de anos e se fez em grandes ciclos geológicos, acompanhados de avanços e recuos da linha de costa de um antigo oceano que circundava o supercontinente Gondwana. Tais mudanças, muito lentas, possibilitaram a formação de rochas de diversas origens: marinha, lacustre, fluvial e glacial, que formam a sequência sedimentar paleozóica da bacia do Paraná (Figura 12). Durante o Jurássico ( $\approx 206$ milhões de anos), essa extensa bacia transformou-se num imenso deserto (Botucatu), com mais de 1,5 milhão de quilômetros quadrados, que cobriu parte do que é hoje o Sul do Brasil e partes do Paraguai, do Uruguai e da Argentina.

No Cretáceo (142 milhões de anos) teve início a grande ruptura do supercontinente Gondwana, separando a América do Sul e a África e formando do oceano Atlântico Sul. Essa separação promoveu a liberação de magma, formando extensos derrames de lavas basálticas sobre as unidades sedimentares paleozóicas (Figura 12). Tais derrames atingiram até $1.500 \mathrm{~m}$ de espessura e cobriram mais de $1.200 .000 \mathrm{~km}^{2}$. A alteração dessas lavas resultou na denominada "terra roxa", solo de alta fertilidade agrícola. Sobre essas rochas, no Noroeste do estado, ocorrem os solos derivados da Formação Caiuá, sedimentos depositados em ambiente desértico 
ao final do Cretáceo. Essas rochas formam solos muito suscetíveis à erosão e pobres do ponto de vista agrícola.

As últimas unidades geológicas a se formarem no estado do Paraná foram os sedimentos da Era Cenozóica (Figura 13). Os exemplos mais expressivos são os originados durante os períodos de clima semiárido. Esses depósitos recobrem áreas dos municípios de Curitiba e Tijucas do Sul; também fazem parte os depósitos sedimentares originados do intemperismo das rochas cristalinas da Serra do Mar, que ocorrem na descida da serra para o litoral, os depósitos marinhos de areia da orla costeira, e os inúmeros solos de aluviões recentes dos rios que cortam o território paranaense.

Por fim, têm-se os sedimentos inconsolidados (aluviões) da Era Cenozóica (65 milhões de anos até os dias atuais), que bordejam os principais cursos de água da região Noroeste do Paraná (Figura 12 e 14).

A área de estudo situa-se no compartimento geomorfológico denominado por Maack (2002) como Terceiro Planalto Paranaense. Este representa o plano de declive que forma a encosta da escarpa da Serra Geral do Paraná, denominada serra da Boa Esperança ou escarpa Mesozóica. É formado por relevos com altitudes que variam de $1.100 \mathrm{~m}$ a $1.250 \mathrm{~m}$ nas escarpas da serra da Boa Esperança e declinam em direção ao rio Paranapanema, ao norte, chegando a aproximadamente $300 \mathrm{~m}$ de altitude, e a oeste, em direção ao rio Paraná, variando entre $220 \mathrm{~m}$ e 300m.

Conforme Nakashina e Nóbrega (2003), esse relevo é, de modo geral, caracterizado por extensos platôs, com topos aplainados, levemente convexos em geral nos divisores das principais bacias hidrográficas como a do Paranapanema, Ivaí, Piquiri, Iguaçu. Nas áreas onde a rede de drenagem é mais densa aparecem colinas médias e curtas, com declividades mais acentuadas, que geralmente ocorrem próximo às nascentes dos principais afluentes e subafluentes. 

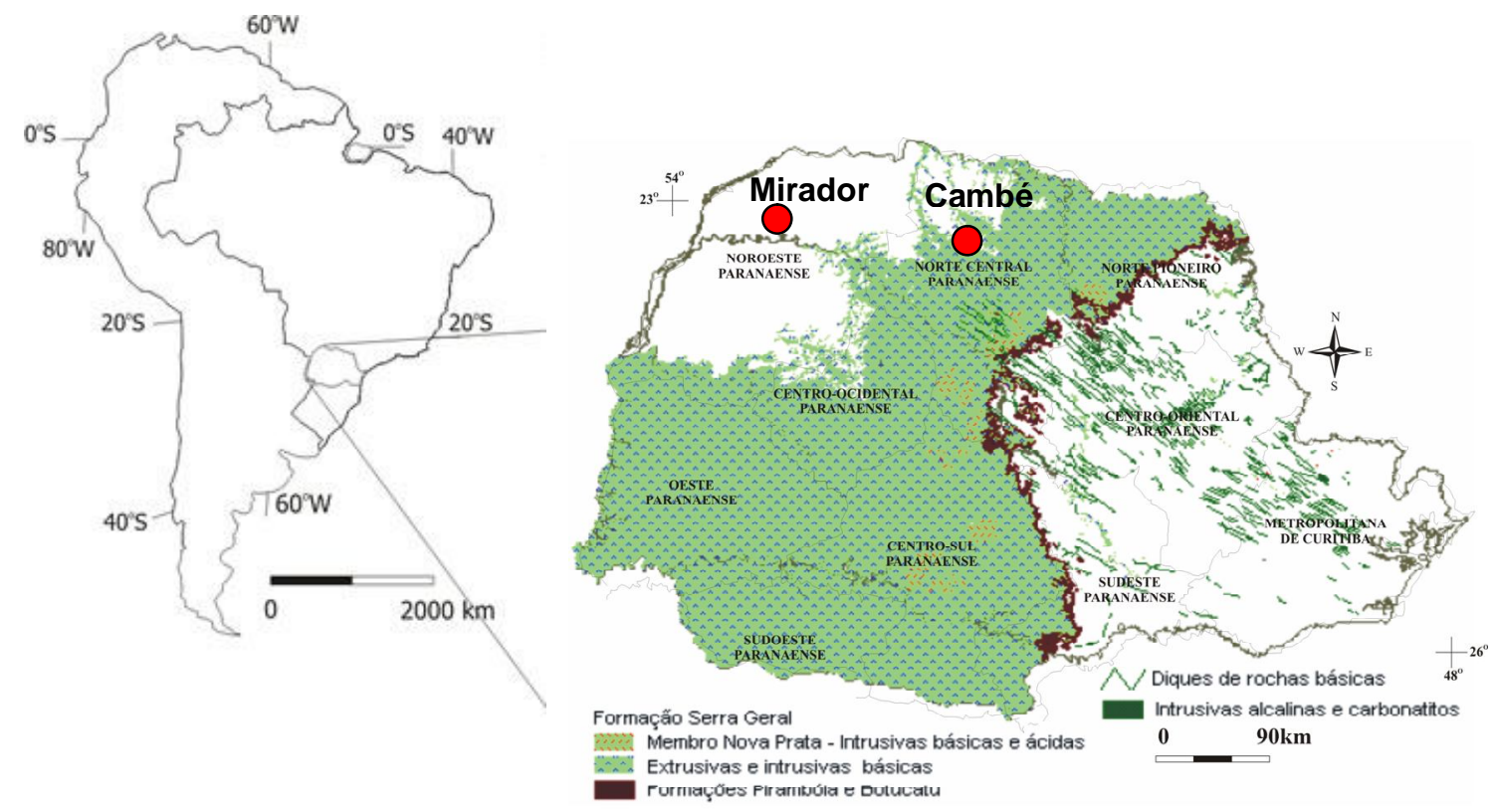

Municípios estudados

Figura 14 - Sedimentação e magmatísmo no Mesozóico. (Mod. MINEROPAR, 2001.

A área desta pesquisa está localizada nos municípios de Cambé e Mirador, pertencentes ao bloco do Planalto de Apucarana (Figura 15).

O Planalto de Apucarana abrange toda a rede de drenagem da margem direita do rio Ivaí, a bacia do rio Pirapó e pequenos afluentes do rio Paranapanema. As áreas mais elevadas, localizadas próximo à serra da Boa Esperança, têm altitude de aproximadamente $1.100 \mathrm{~m}$, decrescendo em direção aos rios Paranapanema, 290m, e Paraná, 235m. Nesse bloco as rochas basálticas ocorrem nos setores Centro e Norte (mesorregião Norte Central paranaense); no setor Noroeste essas rochas estão recobertas pelo Arenito Caiuá (parte da mesorregião Noroeste paranaense).

O relevo desse planalto varia entre suavemente ondulado e plano nos extensos interflúvios dos rios Paranapanema e Ivaí (MAACK, 2002). O município de Cambé, com área de $481 \mathrm{~km}^{2}$, insere-se no setor Norte desse compartimento, com altitudes entre $550 \mathrm{~m}$ e $800 \mathrm{~m}$ e topografia levemente inclinada e ondulada. 


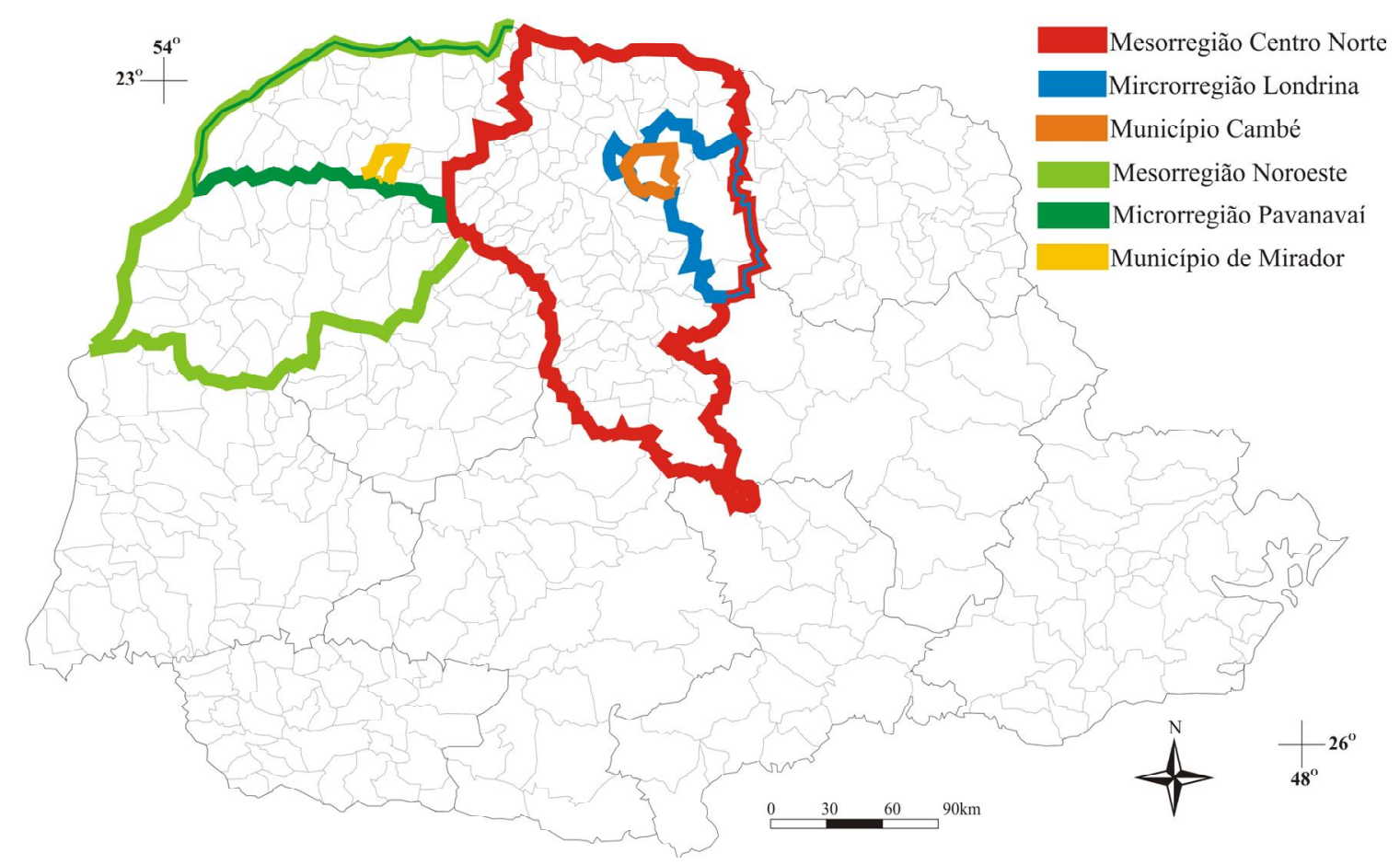

Figura 15 - Mapa do Paraná ilustrando a área estudada, subdividida de acordo com o IBGE em: mesorregiões geográficas, microrregiões e municípios paranaenses. Em destaque os municípios localizados nas mesorregiões Norte Central e Noroeste.

Org.: Domingues, I.A.S. (2008).

O município de Mirador localiza-se no setor Noroeste desse bloco e apresenta altitudes mais modestas que Cambé, em torno de $515 \mathrm{~m}$. O primeiro está inserido na microrregião de Paranavaí e pertence à mesorregião Noroeste paranaense. $O$ segundo município pertence à microrregião de Londrina, mesorregião Norte Central paranaense (Figura 15).

Essas condições de topografia são consideradas propícias para o plantio da cana-de-açúcar, podendo os terrenos apresentar até $12 \%$ de declividade para culturas semimecanizadas. 


\subsection{3 - Aspectos climáticos regionais}

As condições climáticas influenciam diretamente as atividades socioeconômicas, atuando no meio físico e biótico e de forma diferenciada nas diversas zonas de latitudes, sejam elas equatorial, tropical, subtropical ou polar.

Latitudinalmente, a maior parte do estado do Paraná situa-se na zona subtropical, entre as latitudes de 2327'S e 26047'S, embora a parte Norte esteja

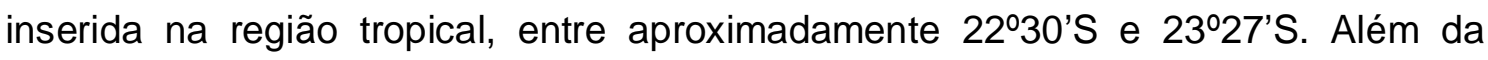
posição geográfica, tem-se a influência de outros aspectos físicos que lhe conferem essa condição.

Conforme Maack (2002), o clima desse estado resulta, além de fatores como a latitude e altitude, da circulação atmosférica (centros de ação anticiclonais e depressionários, responsáveis pela individualização das massas de ar e seus deslocamentos). Esses fatores e suas interações com as correntes marinhas, os ventos alísios de Sudeste e a retração e expansão das massas de ar, determinam sobremaneira o clima geral do Paraná.

Segundo Monteiro (1963), são três, basicamente, os tipos de massas de ar que influenciam o clima no estado. Essas massas são orientadas pelo relevo, bem como pelo sistema de circulação do hemisfério Sul, sendo as massas polares de atuação predominante no inverno e as tropicais marítimas no verão.

A Massa Tropical Atlântica ( $\mathrm{mTa}$ ) tem a propriedade de ser uma massa quente, úmida e com tendência à estabilidade. Porém no verão, com o aquecimento basal e o efeito orográfico ocasionado pelo sistema atlântico, torna-se uma massa instável. No inverno sua atuação é mais marcante quando, devido à sua maior pressão, avança sobre o continente. Além de ter grande poder de penetração no continente, tem atuação durante todo o ano (Monteiro, 1963).

A Massa Tropical Continental (mTc) é uma massa quente e seca, pela origem em área quente e árida, a leste dos Andes e ao sul do Trópico. Sua importância é mais evidenciada durante o verão (Monteiro, 1963).

A Massa Polar Atlântica é uma massa fria e úmida originada em superfície gelada, região de transição entre o ar polar e o tropical. Sua atuação é mais 
marcante no inverno, quando entra na região Sul como uma frente fria, ocasionando chuvas e queda de temperatura com possíveis geadas (NIMER, 1979).

As Correntes Perturbadoras de Oeste afetam a região Sul de forma desigual. No Paraná, é durante o verão que tais correntes o afetam mais fortemente. Durante meados do outono e primavera, o Brasil como um todo é invadido por ventos de W e NW provocados pela Linha de Instabilidade Tropical (IT). Chuvas, trovoadas, granizo e ventos de moderados a fortes são fenômenos acarretados por essa instabilidade (NIMER, 1979).

As Correntes Perturbadoras do Sul têm origem na região polar, onde o ar é seco, frio e estável. Ao longo de sua trajetória sobre o mar absorve calor e umidade. Tem duas vertentes, uma a oeste dos Andes e outra a leste da Cordilheira. Apresenta regularidade nas invasões sobre a região Sul (NIMER, 1979).

A Depressão do Chaco se constitui no mais notável dos centros negativos da América do Sul, sobretudo na região Sul (Monteiro 1963). Sua ocorrência se dá especialmente no verão e está fortemente ligada à dinâmica da Frente Polar. Durante o inverno, em razão do resfriamento do continente, sua atuação é muito restrita, sendo impelida pelas frentes e pelo avanço da Massa Polar.

A Frente Polar Atlântica é uma faixa de descontinuidade gerada pelo choque entre os sistemas intertropicais e polares. Sazonalmente essa frente tem atuações diferenciadas. Na primavera, sua área de atuação pode atingir a latitude $10^{\circ}$ no Mato Grosso, no Norte e no Nordeste. No verão, devido ao seu enfraquecimento, raramente chega a atingir o Paraná. No outono os sistemas intertropicais a fazem regredir. Por fim, no inverno é que se dá a maior atuação da frente, com maior rigor e frequência que nos demais períodos do ano (Monteiro, 1963).

A partir da interação desses fatores, Maack (2000), utilizando dados meteorológicos de temperatura e precipitação, embora escassos e de difícil obtenção para a época, adota a seguinte classificação climática para o Paraná, de acordo com Köppen:

Tipo Af: No litoral as condições predominantes de baixa altitude associada à maritimidade caracterizam o clima do tipo $A f$ - clima tropical chuvoso sempre úmido, sem período seco e mês mais frio acima de $18^{\circ} \mathrm{C}$; 
Tipo Cfa: A designação $C$ advém de climas pluviais temperados e mês mais frio entre $18^{\circ} \mathrm{C}$ e $-3^{\circ} \mathrm{C}$; a letra $f$ refere-se a sempre úmido com chuva em todos os meses do ano e a letra a representa temperatura do mês mais quente superior a $22^{\circ} \mathrm{C}$. O tipo Cfa caracteriza subtropicalidade no vale do rio Ribeira e na vertente atlântica da Serra Mar, condicionada pela latitude e altitude baixas, mas ainda sob forte influência da maritimidade. Na média bacia dos rios Tibagi e Ivaí, na bacia do Piquiri e baixo lguaçu, a continentalidade e as altitudes médias são preponderantes; clima subtropical com geadas periódicas (2 a 3 por ano);

Tipo Cfa(h), periodicamente Cwa: clima tropical marginal modificado pela altitude $(h)$, com geadas raras; caracteriza o clima do Norte e Noroeste do Paraná. A letra $w$ indica condição de período seco no inverno;

Tipo Cfb: temperado quente sempre úmido, com temperatura média do mês mais quente inferior a $22^{\circ} \mathrm{C}$; corresponde à maior parte da região metropolitana de Curitiba e porção Sul do estado até Guarapuava.

Mais recentemente o IAPAR, utilizando base de dados coletados de forma mais sistemática, de temperatura e precipitação, para um período de 26 anos, de 1972 a 1998, define, baseando-se na classificação de Köppen, dois tipos climáticos para o estado do Paraná: Cfa e Cfb (Figura 16). 


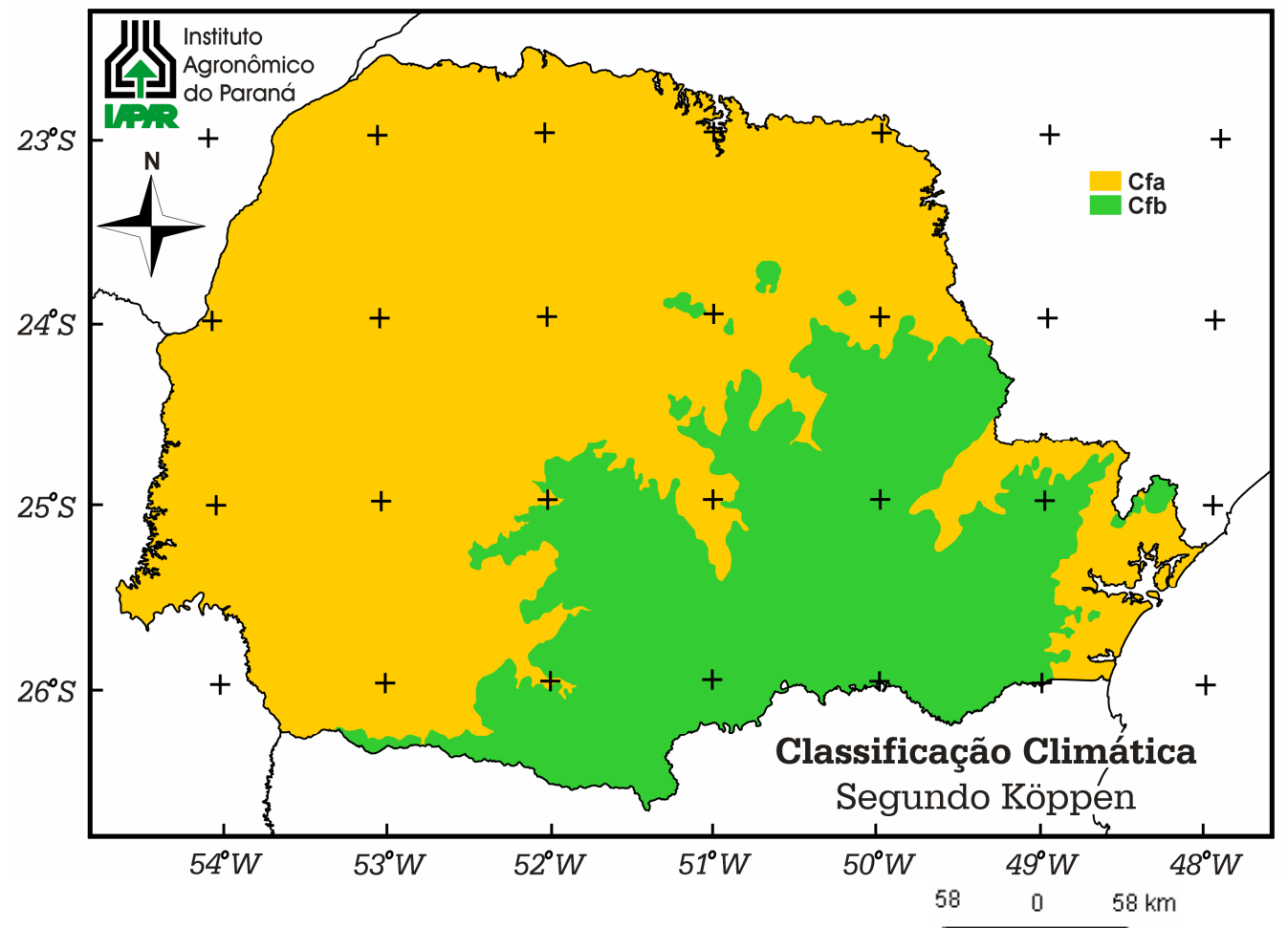

Figura 16 - Classificação climática do Paraná efetuada pelo IAPAR (CAVIGLIONE et al., 2000), com base na classificação climática de Köppen.

Estudo recente de Nagarolli (2007) sobre evolução climática no Paraná mostra que as regiões Norte e parte do Noroeste do estado se enquadram no tipo Cwa, conforme suspeitava Maack, quando afirmou que o clima dessas regiões era do tipo Cfa, eventualmente Cwa (Figura 17). Em 1994, Deffune e Galvani desenvolveram estudo sobre o clima da região de Maringá, localizada no Norte do estado, utilizando dados de 1976 a 1992, e demonstraram que o clima é do tipo Cw'h (clima tropical mesotérmico úmido com chuvas de verão e outono).

Ainda segundo Nagarolli (2007), pela classificação feita pelo IAPAR ocorre uma generalização do tipo climático Cfa, visto que, sendo a precipitação do mês mais seco inferior a $60 \mathrm{~mm}$, já é um clima de tipo "w". Esse valor de precipitação ocorre nas estações localizadas no Norte e Noroeste do estado: Joaquim Távora, Cambará, Bela Vista do Paraíso, Ibiporã, Londrina e Paranavaí.

Portanto, Nagarolli (2007) considera o clima do Norte do Paraná do tipo Cwa, ou seja, um clima temperado quente, e mês de menor precipitação inferior a $60 \mathrm{~mm}$ (Figura 18). 
Sobre o tipo climático $A f$, no litoral do estado, esse autor verificou ainda que, para que fosse tipo $A f$, a temperatura média do mês mais frio deveria ultrapassar $18^{\circ} \mathrm{C}$, o que não ocorre. Em Paranaguá, o mês mais frio registra média de $17,03^{\circ} \mathrm{C}$ e em Morretes $16,39^{\circ} \mathrm{C}$.

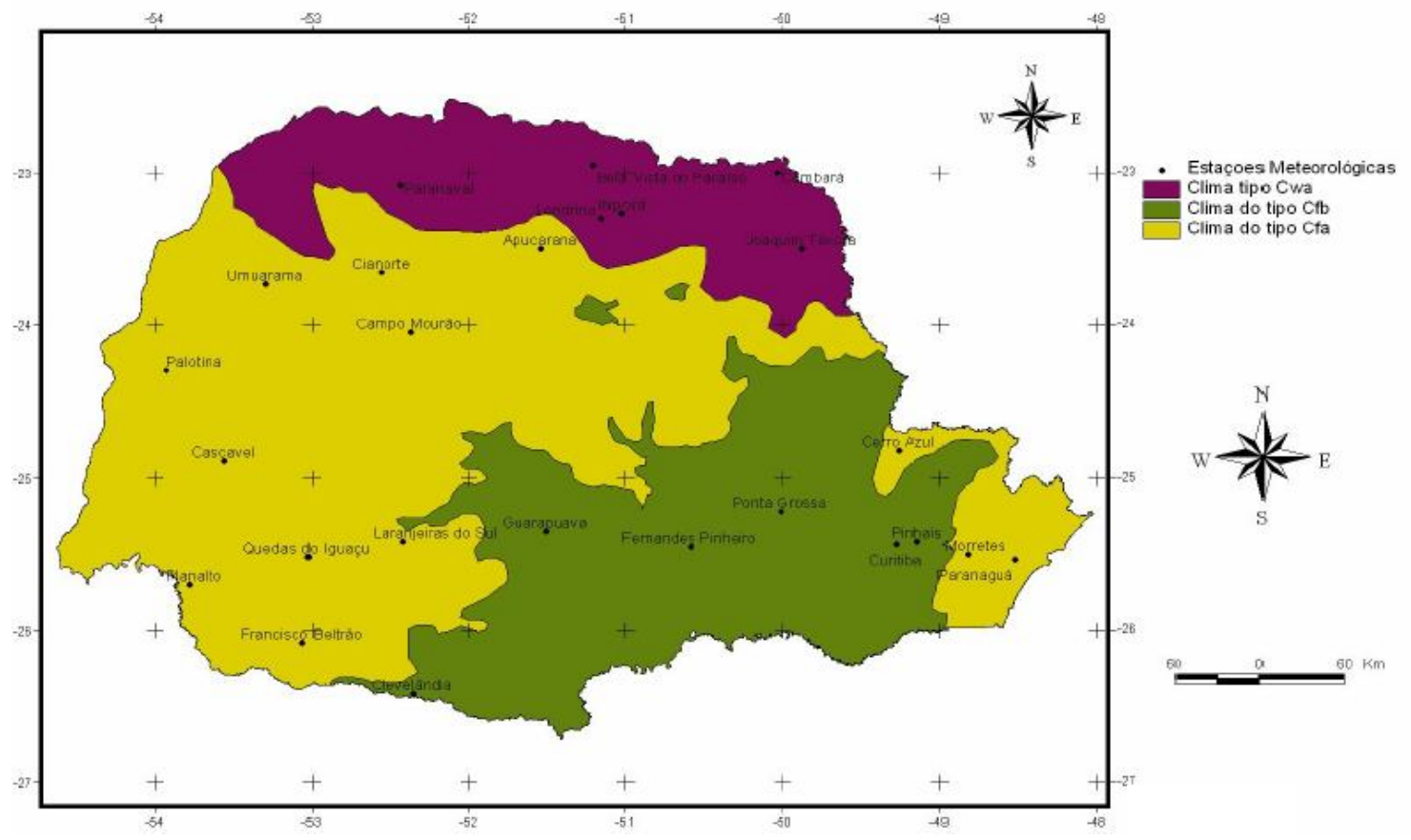

Figura 17 - Tipos de climas do estado do Paraná, segundo critérios de Köppen (NAGAROLLI, 2007).

Considerando as classificações climáticas citadas, a área de estudo apresenta dois tipos climáticos: Cwa e Cfa. Segundo Maack e o IAPAR, o tipo de clima para os municípios de Cambé (mesorregião Norte Central paranaense) e de Mirador (mesorregião Noroeste), é o Cf; entretanto, de acordo com Nagarolli, o município de Cambé tem clima do tipo Cwa. Nesses tipos de clima predominam temperaturas e precipitações que variam, nos setores Norte e Centro da mesorregião Norte Central, de $21^{\circ} \mathrm{C}$ a $22^{\circ} \mathrm{C}$ e de $1.400 \mathrm{~mm}$ a $1.600 \mathrm{~mm}$ anuais, respectivamente; na mesorregião Noroeste, valores de $22^{\circ} \mathrm{C}$ a $24^{\circ} \mathrm{C}$ e de $1.200 \mathrm{~mm}$ a $1.600 \mathrm{~mm}$ (Figura 18). 


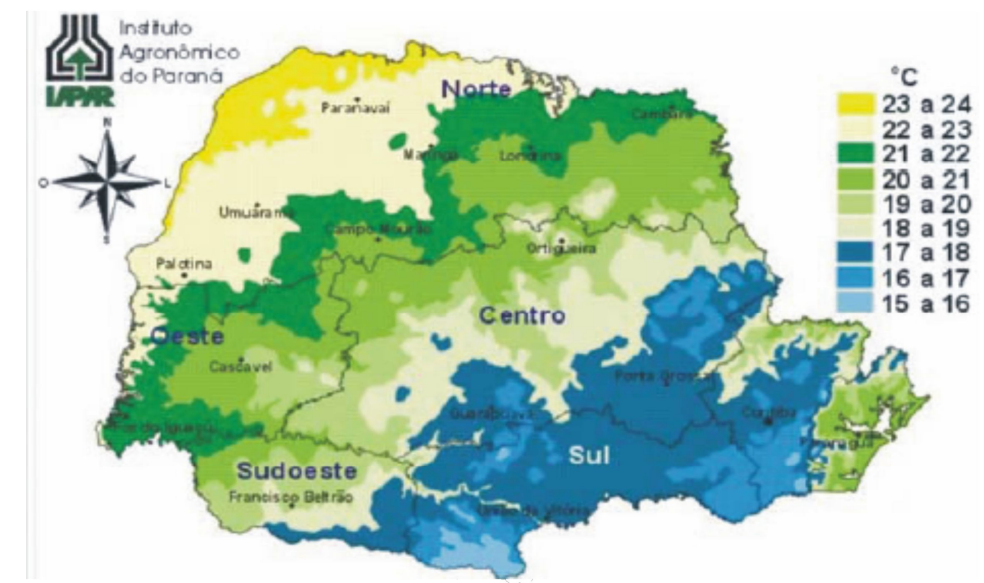

A

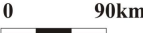

B
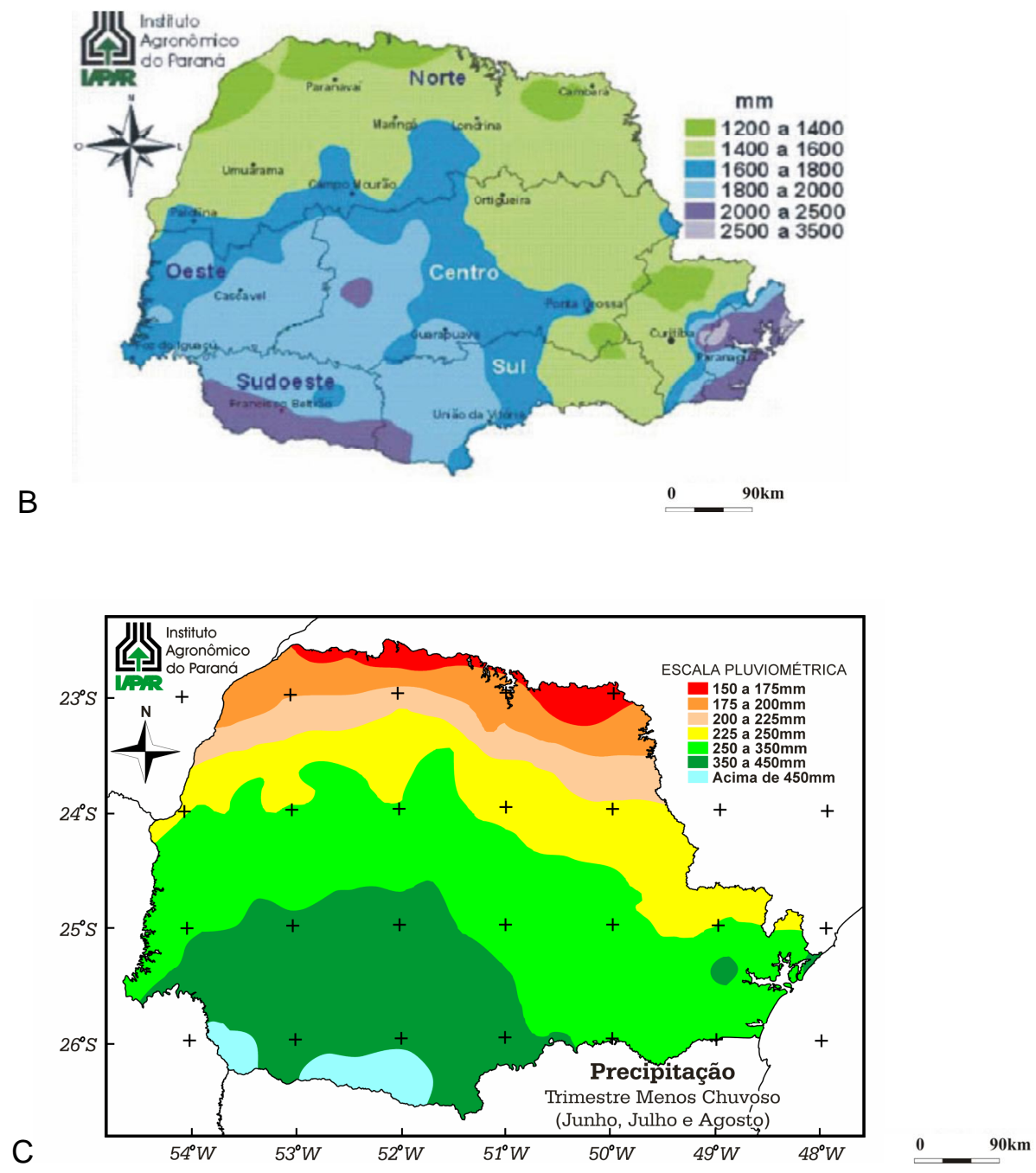

Figura 18 - Temperatura do ar (A) e Precipitação média anual $(B)$ e pluviometria do trimestre mais seco (C) do estado do Paraná da série histórica de 1972 a 1998, (CARAMORI et al., 2003). 
Assim, para melhor compreensão dos processos atmosféricos das regiões onde estão inseridos os dois municípios, têm-se as seguintes características meteorológicas:

Conforme Kim et al. (2000), para a região Norte do estado tem-se um dos menores totais de chuva anual (Figura $18 \mathrm{~B}$ ). $\mathrm{O}$ mesmo autor salienta que a direção média anual dos ventos é de nordeste, embora as componentes de norte e leste também apresentem uma frequência média anual significativa, indicando a influência das circulações oriundas das regiões mais quentes. A frequência média da direção do vento é de leste; os anticiclones são pouco frequentes; a circulação de ar úmido e proveniente da região Sudeste brasileira ameniza um pouco as temperaturas extremas. Também sofre a influência da incursão das massas de ar tropicais, porém a circulação oriunda da região Sudeste brasileira (níveis baixos e médios) mantém a presença da nebulosidade.

A região Noroeste do Paraná é onde se encontram as altitudes mais reduzidas, englobando o vale do rio Ivaí até o Noroeste do estado. Nesta região são observadas as mais elevadas temperaturas mínimas médias mensais (Figura 19). A ação das frentes frias é mais frequente no inverno, embora com baixa frequência, e a atuação de sistemas de mesoescala é menos frequente. Climatologicamente é a região mais quente do estado.

Segundo Wrege et al. (2005), o risco de geadas para a área estudada é de até $20 \%$. Na região de Cambé o risco é maior nos meses de junho e julho, com $10 \%$ e $15 \%$ respectivamente. $\mathrm{Na}$ área de Mirador, o risco é inferior a $10 \%$, sendo de $0,26 \%$ em junho e de $0,15 \%$ em julho; nos demais meses o risco é zero. Tais condições tornam essas áreas aptas ao cultivo da cana-de-açúcar. 


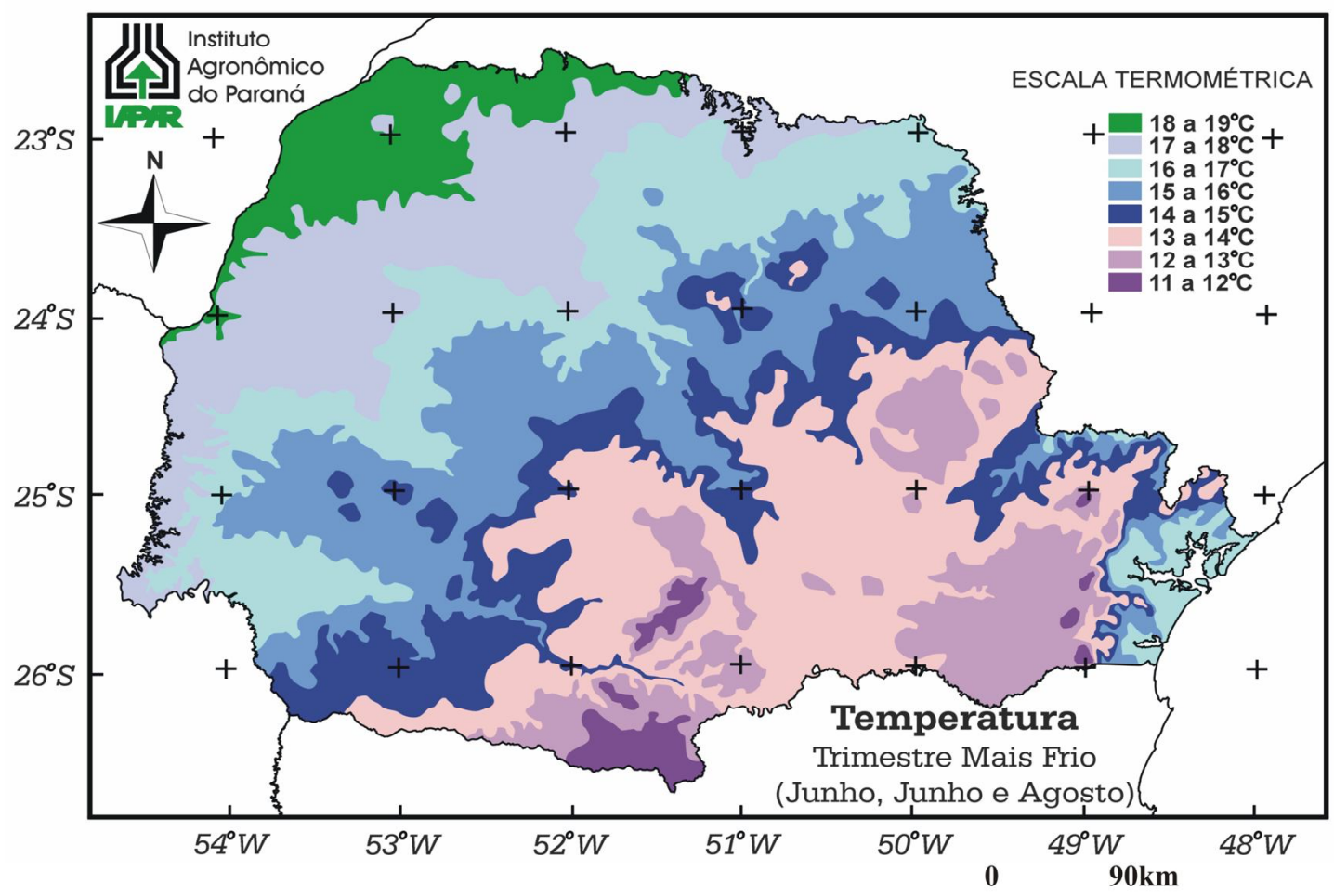

Figura 19 - Temperaturas médias das mínimas para o trimestre mais frio no estado do Paraná (CAVIGLIONE et al., 2000).

\subsection{4 - Aspectos da cobertura pedológica}

As duas áreas de estudo desta pesquisa estão localizadas no Planalto de Apucarana, mais precisamente nos municípios de Cambé e Mirador. O município de Cambé pertence à região Norte Central paranaense, enquanto Mirador faz parte da região Noroeste. Embora esses municípios estejam localizados sobre o mesmo planalto, a cobertura pedológica difere de forma significativa, em decorrência dos diferentes tipos litológicos presentes (Figura 20). Os solos da região de Cambé são argilosos, profundos, bem drenados e desenvolvidos, provenientes da alteração de rochas vulcânicas básicas, típicas daquela região. Por outro lado, Mirador está assentado sobre rochas sedimentares da Formação Caiuá, o que, aliado ao clima, deu origem a uma cobertura de solos arenosos, profundos, bem drenados e desenvolvidos. 


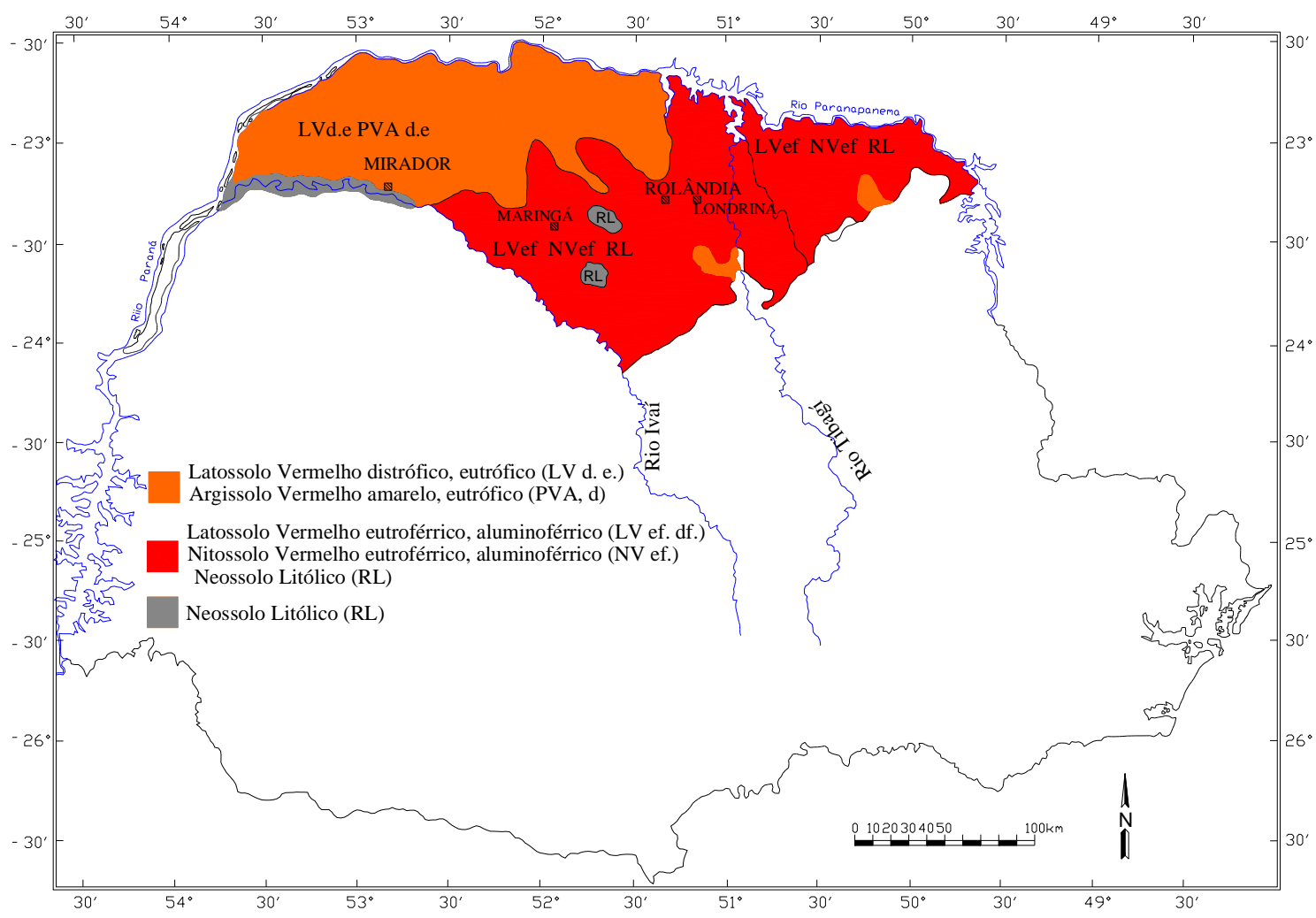

Figura 20 - Tipologia pedológica da área estudada. (Mod. NAKASHINA; NÓBREGA, 2003).

A distribuição e o desenvolvimento da cobertura pedológica apresentam, de modo geral, estreita relação com o clima, o relevo e a rocha sotoposta. Nas áreas de ocorrência das rochas basálticas (Formação Serra Geral), onde o relevo é plano a suavemente ondulado, predomina o Latossolo Vermelho, textura argilosa, principalmente nos topos dos interflúvios e altas vertentes; a partir daí, em direção a jusante, surgem os Nitossolos Vermelhos, nas médias e baixas vertentes, enquanto o Cambissolo e Gleissolo podem se desenvolver junto às principais drenagens.

Nas áreas de ocorrência do "Arenito Caiuá", o Latossolo Vermelho, textura arenosa/média, aparece predominantemente nos topos e altas vertentes; o Argissolo Vermelho-Amarelo e/ou o Argissolo Vermelho, com textura argilosa a arenosa/média, ocorrem nas médias e baixas vertentes, podendo alcançar o terço inferior das mesmas (NAKASHINA; NÓBREGA, 2003) (Figura 21). Gaspareto e Souza (2003) afirmam que a cobertura pedológica predominante sobre o "Arenito Caiuá" obedece à sequência de Latossolos nos topos e altas vertentes, Argissolos 
(AG) nas médias vertentes, os Neossolos Quartzarênicos (NQ) nos sopés das encostas e os Gleissolos próximos às margens das principais drenagens (Figura 21).

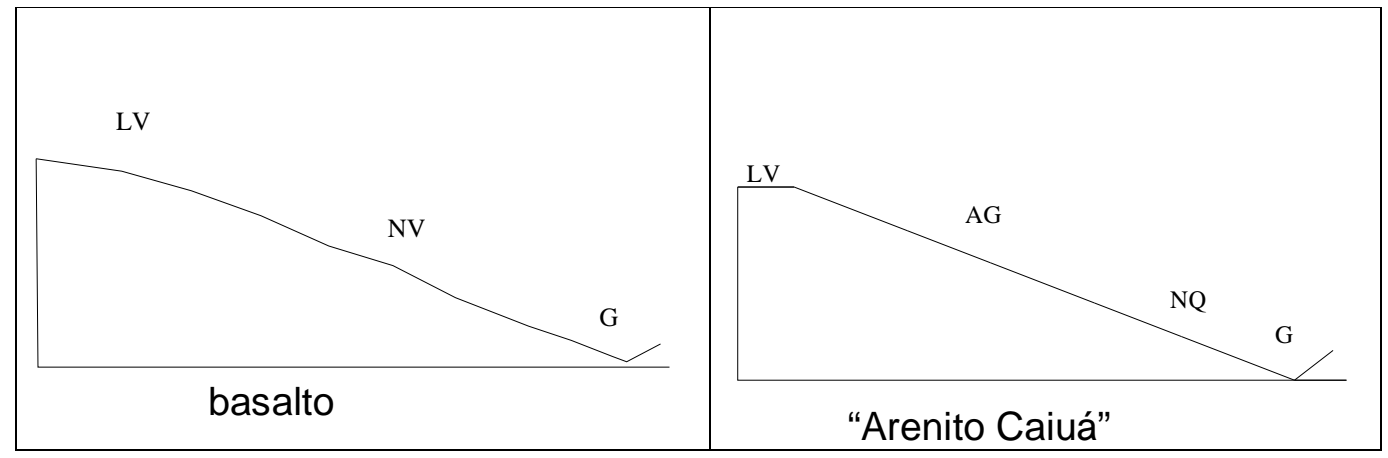

Figura 21 - Topossequência esquemática de tipos de solos originados de rochas da Formação Serra Geral (Basalto) e da Formação Caiuá (Arenito Caiuá). LV- Latossolo Vermelho; NV- Nitossolo; AGArgissolo; NQ- Neossolo Quartzarênico; G-Gleissolo, (Mod. NAKASHINA; NÓBREGA, 2003).

De modo geral, os solos com as características descritas se enquadram nas condições exigidas ao cultivo da cana-de-açúcar. Normalmente, essa cultura se desenvolve melhor em solos férteis, argilosos, com boa capacidade de retenção de água, boa aeração, boa drenagem e com profundidade superior a um metro (COOPERSUCAR, 1998). Porém, como é uma cultura com boa adaptabilidade às condições do meio físico, pouco exigente em termos de fertilidade, ela é encontrada em todo o Noroeste paranaense, em solos com textura arenosa derivados do arenito. Mesmo assim, a cana-de-açúcar apresenta bom grau de desenvolvimento e de produção.

Segundo Kofler e Donzeli (1987), a cana-de-açúcar apresenta grande adaptabilidade pedológica. Pode ser cultivada tanto em solos arenosos, que apresentam como limitações a baixa capacidade de armazenamento de água e a alta taxa de perda de nutrientes por lixiviação, quanto em solos muito argilosos, que podem apresentar uma drenagem mais lenta, propiciando menor aeração da zona radicular e também alta suscetibilidade à compactação, que é limitante à penetração das raízes. Entretanto, cada solo apresentará vantagens e limitações inerentes à 
sua classificação e que devem ser consideradas quando de sua utilização para a cana-de-açúcar.

\subsection{5 - Aspectos da cobertura vegetal}

Naturalmente tem-se, pela função da latitude e da altitude/relevo, que a vegetação é a expressão do clima. O estado do Paraná situa-se entre as latitudes aproximadas de 2230'S a 2640'S, onde os seus terrenos, em grande maioria, apresentam topografias modestas. Esse estado foi, até aproximadamente a década de 1930, uma das áreas mais ricas em matas do Brasil. As matas ocupavam em torno de $80 \%$ da superfície de uma área oficial do estado de $199.729 \mathrm{~km}^{2}$. As maiores extensões eram ocupadas por mata pluvial-tropical-subtropical ( $\approx 94$ mil $\mathrm{km}^{2}$ ), seguida da mata de araucária nos planaltos, na região da mata subtropical (73.8 mil km²), acima de 500 metros do nível do mar, e na de Campos Limpos e Campos Cerrados ( $\approx 30.5$ mil km²) (MAACK, 2002). Em consequência da destruição antrópica, atualmente a cobertura vegetal dominante é o mato secundário, incluindo as áreas agrícolas, ocupando extensão em torno de $119.688 \mathrm{~km}^{2}, 60 \%$ da área do estado.

Em levantamento realizado pela Fundação SOS Mata Atlântica/INPE (2001), restavam no ano 2000 , no Paraná, $15.943 \mathrm{~km}^{2}$ (7,98\%) de cobertura florestal. O Ministério do Meio Ambiente e a Fundação de Pesquisa e Estudos Florestais, ligada à Universidade Federal do Paraná (UFPR), completaram em 2001 trabalho indicando com detalhes a discriminação dos ambientes de floresta com araucária, ainda remanescentes no Paraná. Ressalte-se a constatação de que não mais do que $0,8 \%$ de áreas da Floresta Ombrófila Mista, originalmente formada por 8 milhões de hectares, ainda perduravam no estágio avançado de conservação. Estudo recente de Padilha Junior (2004) mostra uma evolução temporal da cobertura florestal no estado do Paraná, estando incluídas também, aquelas em estágio de sucessão (Tabela 5).

A Floresta Estacional Semidecidual está restrita às porções Oeste, Noroeste e Norte do Paraná, correspondendo ao baixo Iguaçu e parte da bacia do rio Paraná, 
ao sul do divisor de águas Ivaí-Piquiri. Essa formação vegetal sul-brasileira estendese ainda até o Rio Grande do Sul, na bacia do Rio Uruguai, chegando a atingir a Argentina.

Tabela 5 - Evolução temporal da cobertura vegetal no estado do Paraná (PADILHA JUNIOR, 2004).

\begin{tabular}{c|c|c}
\hline Ano & $\begin{array}{c}\text { Cobertura Florestal } \\
\text { (milhões ha) }\end{array}$ & $\begin{array}{c}\text { Percentual de cobertura } \\
(\%)\end{array}$ \\
\hline 1500 & 17,0 & 85,0 \\
\hline 1895 & 16,8 & 83,4 \\
\hline 1930 & 12,9 & 64,1 \\
\hline 1937 & 11,8 & 59,6 \\
\hline 1950 & 8,0 & 39,7 \\
\hline 1955 & 6,9 & 34,9 \\
\hline 1960 & 5,6 & 28,1 \\
\hline 1965 & 4,8 & 23,9 \\
\hline 1980 & 3,4 & 17,0 \\
\hline 1990 & 1,8 & 9,2 \\
\hline 1999 & 1,7 & 8,8 \\
\hline 2003 & 1,7 & 8,8 \\
\hline
\end{tabular}

Org.: Domingues, I.A.S. (2008).

Essa formação relaciona-se em toda a sua área de ocorrência a um clima com duas estações definidas, uma chuvosa e outra seca. Tal característica climática é um dos fatores determinantes de uma forte estacionalidade foliar dos elementos arbóreos dominantes, como resposta ao período de deficiência hídrica. É uma floresta constituída por árvores emergentes que atingem entre $25 \mathrm{~m}$ e $30 \mathrm{~m}$ de altura, sem formar cobertura superior contínua. Seus troncos são grossos e alongados, encimados por copa larga.

As espécies mais importantes desse estrato da floresta são: a peroba (Aspidosperma polyneuron), a mariapreta (Diatenopterix sorbifolia), a grápia (Apuleia leiocarpa), o alecrim (Holocalyx balansae) e o pau-marfim (Balfourodendron riedelianum). Algumas dessas espécies perdem totalmente suas folhas durante 0 inverno, quando se torna visível um segundo estrato arbóreo, mais denso e perenifólio (folhas velhas não caem antes de as novas já se terem desenvolvido), com altura entre $15 \mathrm{~m}$ e $20 \mathrm{~m}$, formado principalmente por lauráceas, dentre as quais se destacam a canela-preta (Nectandra megapotamica), a canela-imbuia (Ocotea dyospirifolia), dentre outras. 
A cobertura florestal da Floresta Estacional Semidecidual foi praticamente dizimada, restando como remanescente significativo apenas o Parque Nacional do Iguaçu, com 185.262ha, mesclado com um pequeno trecho de floresta com araucária. As florestas encontram-se extremamente fragmentadas, com remanescentes de tamanhos exíguos e muito degradadas.

Para as áreas agrícolas, no estado do Paraná foram identificados 14,5 milhões de hectares de terras com vocação para lavouras; 2,8 milhões para pastagem plantada; 0,9 milhão para silvicultura e pastagem natural; 1,6 milhão de hectares de terras sem aptidão para uso agrícola, que correspondem a $8 \%$ da superfície estadual (AMBIENTEBRASIL, 2008).

As terras indicadas para lavouras perfazem $73 \%$ da área do estado. Desse total, $52 \%$ permitem a exploração com culturas de ciclos curtos e longos, $8 \%$ de ciclo curto, com um cultivo por ano, e 58\% com dois cultivos por ano.

Constituindo uso alternativo com pastagem plantada, as culturas de ciclo longo podem ocupar 1,6 milhão de hectares, que abrangem $8 \%$ do estado. As culturas especiais de ciclo longo, no caso do Paraná, representadas pela fruticultura de clima temperado, são indicadas para 6,2 milhões de hectares, que totalizam $31 \%$ da extensão do estado.

A área indicada para o cultivo de espécies que necessitam de alto nível tecnológico, com mecanização presente nas diversas fases da operação agrícola, compreende $53 \%$ da superfície do estado.

As características da vegetação nas mesorregiões Norte (Central e Pioneiro) e Noroeste paranaense são as seguintes (Figura 22):

Para a primeira mesorregião, com extensão 2.335.700ha, o domínio foi para a mata tropical subperenifólia, que, embora se classifique dentro do mesmo tipo de formação, apresenta variações fisionômicas de acordo com o tipo de solo. Comparativamente, a mata instalada sobre os solos da Formação Caiuá, comumente tem árvores mais finas e de menor porte em relação às da terra roxa e demais solos originados do derrame basáltico. Quanto às lavouras, estas abrangem 2.051.160ha, que correspondem a $87,80 \%$ da área dessa mesorregião. Desses, $86,60 \%$ permitem o desenvolvimento de lavouras com culturas de ciclos curto e longo. 


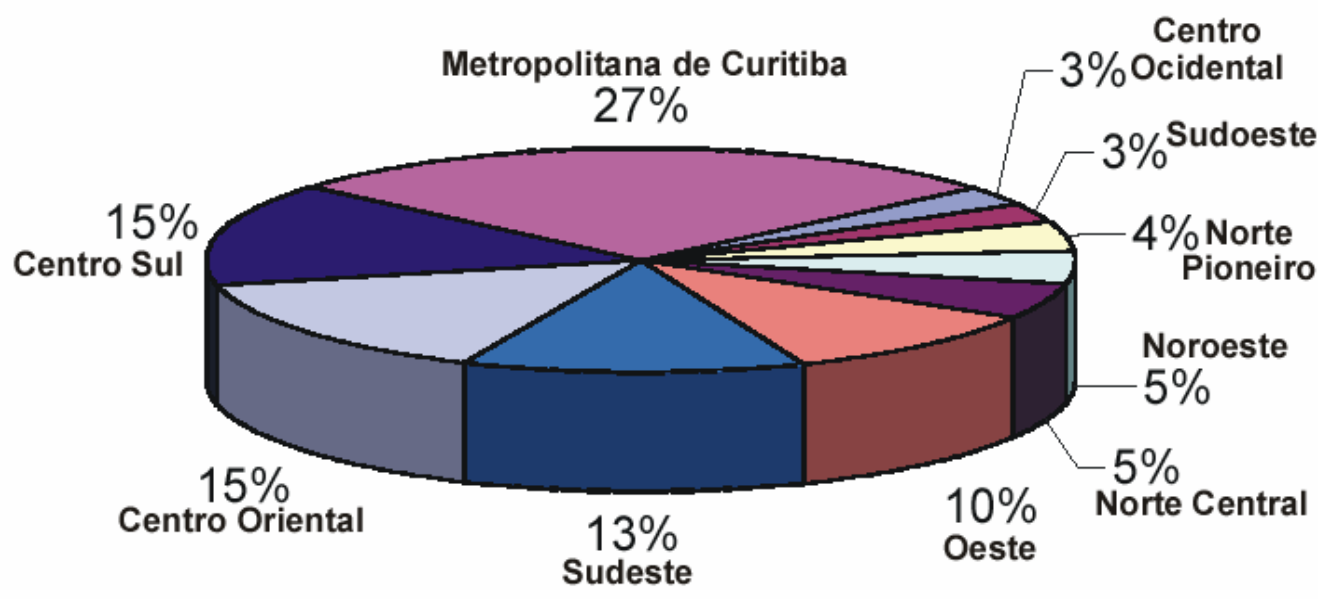

Figura 22 - Distribuição do estado atual das florestas do Paraná por mesorregiões geográficas paranaenses (PADILHA JUNIOR, 2004).

A segunda mesorregião foi originariamente domínio da mata tropical, da qual restam poucos remanescentes, que se apresentam menos exuberantes em algumas áreas, em decorrência da pobreza dos solos. Quanto à vegetação secundária, dois terços dessa mesorregião são próprios para o uso com lavouras, já que essa indicação é extensiva a 655.896ha. Desse valor, 631.096ha, o equivalente a 96,20\%, permitem sua utilização com culturas de ciclos curto e longo, sendo que 98.300ha dessas terras possibilitam cultura de ciclo curto, com dois cultivos anuais.

No município de Cambe, mesorregião Norte Central, a área ocupada com lavouras, até 2006 , foi de 62.230 ha, dos quais 60.140 ha com lavoura temporária. A cultura da cana-de-açúcar ocupou área de 600ha, aproximadamente $1 \%$ daquela com culturas anuais. O município de Mirador, mesorregião Noroeste, tem atualmente como principal atividade econômica do Projeto Arenito as culturas de soja e cana-deaçúcar. Esta última com área de 2.433ha. 


\section{3 - Procedimentos}

A proposta de estudo necessitou abordar procedimentos metodológicos para alguns enfoques dentro da pesquisa, utilizando para tal dois tipos de bases de dados. Esses enfoques dizem respeito à evolução espaço-temporal da cultura da cana-de-açúcar; à dinâmica climática dos elementos precipitação e temperatura; à contabilização do balanço hídrico para DEF (deficiência hídrica) e EXC (excedente hídrico); e à correlação entre clima e produtividade da cana-de-açúcar.

\subsection{1 - Bases de dados}

Das bases de dados adquiridas, uma se referiu a dados de produção agrícola do cultivo da cana-de-açúcar e outra a dados climáticos, entre eles precipitação e temperatura do ar da área estudada.

Para a primeira, as fontes de busca foram o Instituto Brasileiro de Geografia e Estatística (IBGE), por meio dos anuários de produção agrícola municipal para a série temporal de 1982 a 1989 e o acervo PAM (Produção Agrícola Municipal) da série temporal de 1990 a 2006, totalizando uma série de 25 anos.

Além desse instituto, obtiveram-se dados informativos de produção da canade-açúcar dos municípios de Cambé e Mirador por meio de duas usinas sucroalcooleiras, Corol e Coopcana. Estas disponibilizaram informações sobre o cultivo, como data de plantio e colheita, ciclo da cana etc. Essas usinas recebem parte da produção canavieira dos municípios de Cambé e Mirador. A Corol fica a $10 \mathrm{~km}$ de Cambé, a Coopcana a $17 \mathrm{~km}$ de Mirador.

A segunda base de dados foi obtida do Instituto Agronômico do Paraná (IAPAR), abrangendo uma série de dados de chuva e temperatura de 31 anos (1976 a 2006) das estações climatológicas dos municípios de Paranavaí e Londrina. 
3.3.2 - Procedimento metodológico para a evolução espaço-temporal da cultura da cana-de-açúcar na região estudada

Os dados da produção agrícola utilizados na análise da evolução espaçotemporal envolveram três variáveis: de área plantada (ha), de quantidade produzida ou produção (ton) e de produtividade (ton/ha), referentes ao período de 1982 a 2006 para as localidades de Cambé e Mirador e de 1990 a 2006 para as demais regiões consideradas. Utilizando dados de área plantada e de produção, calcularam-se os dados de produtividade - equação 1 .

$$
\text { Produt }=\operatorname{Prod} / \mathrm{A}
$$

em que

Produt $=$ produtividade ton $/$ ha;

Prod $=$ produção de colmos (ton)

$\mathrm{A}=$ área colhida (ha)

Os dados dessas três variáveis foram organizados em planilhas do software Excel e seus resultados apresentados em tabelas e gráficos, sendo utilizados também na geração de mapas com a ajuda de um SIG (Sistema de Informação Geográfica - SPRING) e de um Software (Corel Draw 12) para a apresentação do layout.

A representação espaço-temporal das variáveis de produção (área plantada, produção e produtividade) foi agrupada de quatro em quatro anos (1990, 1994, 1998, 2002 e 2006), intercalando-se nesses intervalos os anos que apresentaram as maiores variações dos dados de rendimentos (2000 e 2005).

Devido à desproporção numérica dos dados de cada uma das variáveis, foi utilizado para os intervalos de classes o método Coroplético (representações quantitativas, manifestações zonais) (MARTINELLI, 1991). O vocábulo "coroplético" vem do grego, onde choros significa lugar e plethos quantidade. Essa forma pode representar um histograma tridimensional ou uma superfície estatística, com descontinuidade na passagem de uma unidade observacional para outra. 
Visualmente, podem-se isolar agrupamentos naturais de pontos, os quais formarão as classes que não poderão ser muito numerosas, no máximo de sete, devido às limitações de percepção visual.

Para a representação das três variáveis (área, produção e produtividade) na forma de mapa, para o trabalho em questão, aplicou-se essa metodologia. Para tal utilizaram-se seis intervalos de classes. As classes foram representadas por cores, que se intensificaram de acordo com 0 aumento nos valores dos dados correspondentes (primeira classe alta diminuindo em direção a sexta, muito baixa), as quais podem remeter à seguinte ordem:

\begin{tabular}{ll}
\multicolumn{1}{c}{ Classe } & Variável \\
$1^{\underline{\underline{a}}}$ & Alta \\
$2^{\underline{a}}$ & Média alta \\
$3^{\underline{a}}$ & Média \\
$4^{\underline{a}}$ & Média baixa \\
$5^{\underline{a}}$ & Baixa \\
$6^{\underline{a}}$ & Muito baixa
\end{tabular}

\subsection{3 - Procedimento metodológico para a análise da pluviometria e da temperatura}

Para a caracterização climática da área, foram utilizadas as médias mensais e anuais de precipitação pluviométrica e de temperatura, as quais possibilitaram o conhecimento, em específico, da variabilidade climática das áreas estudadas de dois municípios (Cambé e Mirador).

Para tal, utilizaram-se a frequência relativa de chuvas, a média aritmética e o desvio em relação à média. De acordo com diversos pesquisadores (SANT'ANNA NETO, 1996; SANTOS, 1996, 1992; CHRISTOFOLETTI, 1992; AYOADE, 1991; CRESPO, 2002 etc.), esse procedimento é considerado também adequado para expressar a variação dos valores de um elemento dentro de um determinado período de tempo. 
A frequência relativa de chuvas mostra o número de vezes em que determinado evento ocorreu ( $n a)$ em relação ao número total de elementos da série (n). Numericamente é dada por:

$$
f r=\frac{n a}{n}
$$

Utilizaram-se seis intervalos de classes de frequência, com chuvas ocorridas em 24 horas, expressos por:

$<1,0$ - Considerado dia sem chuva;

$>1,01<10,0 \mathrm{~mm}$

$>10,01<30,0 \mathrm{~mm}$

$>30,01<50,0 \mathrm{~mm}$

$>50,01<80,0 \mathrm{~mm}$

$>80,01 \mathrm{~mm}$

O desvio em relação à média é a diferença entre cada elemento de um conjunto de valores e a média aritmética. O desvio pode ser calculado pela equação 3.

$$
d_{i}=x_{i}-\bar{X}
$$

sendo

$d_{i}$ o desvio em relação à média;

$x_{i}$ os valores das variáveis (precipitação pluvial, temperatura);

$\bar{X}$ a média aritmética. 
3.2.4 - Procedimento metodológico para determinar tendência tecnológica na produtividade da cana-de-açúcar

A determinação da tendência tecnológica é uma técnica que visa separar o efeito tecnológico incorporado no sistema de produção ao longo do tempo no rendimento da cultura.

A verificação do nível da tendência tecnológica necessitou dos dados de produtividade da série temporal de 1981 a 2006 dos municípios de Cambé e Mirador, obtidos por meio da PAM/IBGE (Produção Agrícola Municipal). A metodologia utilizada foi baseada em Cunha et al. (1999) e Carmona e Bertalo (2002).

Os dados dessa série temporal de produtividade foram submetidos inicialmente a uma análise de regressão para verificação da tendência tecnológica. A retirada da tendência tecnológica, dos dados de rendimento, foi realizada utilizando-se a seguinte expressão:

$Y c i=(Y i-(Y(x i)-Y(x o))$,

na qual

Yci é a produtividade corrigida do ano i;

Yi é a produtividade original do ano i;

$\mathrm{Y}(\mathrm{xi})$ é a produtividade do ano i, estimada pelo modelo de regressão;

$\mathrm{Y}(\mathrm{xo})$ é a produtividade do primeiro ano da série histórica de produtividade, estimada pelo modelo de regressão.

Após a retirada da tendência tecnológica dos dados originais obteve-se uma nova série de dados, a qual foi submetida ao cálculo dos desvios em relação à média. Esses desvios ou anomalias do rendimento, positivos ou negativos, foram comparados com os dados de precipitação pluvial dos anos agrícolas do período de 1981 a 2006. Também foram comparados os dados por série quadrimestral, condizentes com o ciclo de cultivo tradicional da cultura da cana-de-açúcar (boa 
parte do ciclo acontece normalmente de setembro a dezembro do ano seguinte, período de germinação/estabelecimento, de janeiro a abril, desenvolvimento, e de maio a agosto, maturação e colheita).

Entretanto, é pratica comum dos produtores de cana-de-açúcar adotar épocas de cultivo de acordo com as necessidades das usinas sucroalcooleiras. Um exemplo: nas regiões produtoras de soja, usa-se em alguns anos intercalar a soja (plantada em torno de outubro, com ciclo de seis meses) com a cana-de-açúcar. Nesse ano, em específico, começa o plantio da cana-de-açúcar no mês de março, quando se encerra a colheita da soja. O período de colheita da cana-de-açúcar nesse caso é controlado com maturadores.

\subsection{5 - Procedimento metodológico para a contabilização do balanço hídrico}

O Balanço Hídrico $(\mathrm{BH})$ é a contabilização da água do solo, resultante da aplicação do Princípio de Conservação de Massa num volume de solo vegetado. A variação de armazenamento de água no solo por unidade de tempo representa o balanço entre o que entrou e o que saiu de água do volume de controle, este definido pela profundidade das raízes. Dessa forma, o $\mathrm{BH}$ é uma das maneiras de monitoramento da variação do armazenamento de água no solo, determinante para a produtividade de uma dada cultura (PEREIRA et al., 2002).

O BH é uma técnica proposta por Thornthwaite e Mather (1955), que utilizam basicamente dados de precipitação pluviométrica e de temperatura do ar para calcular a contabilização e demonstrar a variação da água no solo.

A água que entra na unidade de volume do solo é representada por: Precipitação (P), Irrigação (I), Orvalho (O), Escoamento Superficial (Ri), Drenagem Lateral (DLi) e Ascensão Capilar (AC); e a água que sai é representada por: Evapotranspiração (ET), Escoamento Superficial (Ro), Drenagem Lateral (DLo) e Drenagem Profunda (DP). Como o escoamento superficial (Ri e Ro) e a drenagem lateral (DLi e DLo) tendem a se compensar no volume de controle, tem-se que a 
variação do armazenamento de água no solo ( $\pm \Delta \mathrm{ARM})$ pode ser expressa pela equação 4.

$$
\pm \triangle A R M=P+I-E T+A C-D P
$$

Dessa forma, é possível por meio desse cálculo conhecer, dentre outras, as variáveis sobremaneira determinantes para a produtividade de uma dada cultura, como a evapotranspiração tanto real como potencial (ETR e ETP), a deficiência (DEF) e o excedente hídrico (EXC) e o armazenamento de água no solo (ARM).

$\mathrm{Na}$ elaboração do balanço hídrico climatológico, além de se determinar a variação do ARM, calcula-se previamente a CAD - lâmina de água correspondente ao intervalo de umidade do solo entre a Capacidade de Campo e o Ponto de Murcha Permanente, bem como a ETP. Esta pode ser calculada pela equação 5.

\section{$C A D=0,01^{\star}(C C \%-P M P \%)^{\star} D^{\star} Z$}

na qual

$\mathrm{CC} \%$ = porcentagem de água no solo em capacidade de campo;

PMP\% = porcentagem de água no solo no ponto de murcha;

$D$ = massa específica do solo;

$Z$ = profundidade efetiva do sistema radicular.

O cálculo da ETP pode ser estimado utilizando-se diversos métodos, dependendo da disponibilidade de dados meteorológicos. Dentre os métodos existentes (Thornthwaite, Camargo, Tanque Classe A, Hargreaves; Samani, Penman-Monteith), aquele que necessita apenas de um elemento meteorológico, índice térmico, é o de Thornthwaite (1955), que pode ser estimado pela equação 6.

na qual 
$\mathrm{Tn}=$ temperatura $(\stackrel{\circ}{)})$ média do mês;

I=índice que expressa o nível de calor disponível na região, sendo $I=\sum$ (mês 1 ao $12)^{\star}\left(0,2^{\star} \mathrm{Tn}\right)^{1,514}$;

$\mathrm{n}=$ representa 0 mês;

$\mathrm{a}=$ por ser uma função de I também é um índice térmico regional, calculado pela seguinte expressão: $a=6,\left.75^{*} 10^{-7 *}\right|^{3}-7,\left.71^{*} 10^{-5 *}\right|^{2}+1,7912^{*} 10^{-2 *} \mid+0,49239$.

Como esses cálculos são para meses de 30 dias de 12 horas de fotoperíodo, é necessário fazer a seguinte correção: $\mathrm{ETP}=\mathrm{ETp}{ }^{*} \mathrm{Cor}$, na qual $\mathrm{Cor}=\mathrm{ND}{ }^{*} \mathrm{~N} /\left(30^{*} 12\right)$ ou ainda $E T P=E T^{*}{ }^{*} r^{*} N D$, sendo

Cor= correção, encontra-se tabelada (CAMARGO, 1962);

$\mathrm{ND}=$ número de dias do mês;

$\mathrm{N}=$ fotoperíodo médio do mês.

Dentre as técnicas para efetuar os cálculos do $\mathrm{BH}$ utilizou-se programa computacional desenvolvido por Rolim, et al. (1998), que permite calcular o BH para diversos tipos de aplicações de curtos períodos de tempo, desde uma escala de dias até anos.

Para os propósitos desta pesquisa utilizou-se o BH Climatológico (ou Normal), $\mathrm{BH}$ Sequencial e BH de Cultura. Cada um desses tipos de BH apresenta finalidades distintas, a saber:

Por meio do BH Climatológico é possível efetuar, numa escala mensal com valores médios de vários anos (normal climatológica), a caracterização e a comparação climática regional quanto à disponibilidade hídrica média no solo; a caracterização das secas; a caracterização da aptidão hídrica regional para culturas; e determinação das melhores épocas de semeadura.

$\mathrm{O} \mathrm{BH}$ Sequencial possibilita o acompanhamento em tempo real da disponibilidade de água no solo. Além de outras utilidades, pode-se acompanhar a 
disponibilidade de água no solo ao longo de vários anos e sua comparação com um ano médio (normal), o que permite a quantificação de danos provocados às culturas.

Para corroborar a verificação das condições de produtividade da cultura estudada, aplicou-se ainda o BH de Cultura. Essa técnica visa calcular o balanço de água no solo levando-se em consideração tanto o tipo de vegetação como sua fase de crescimento e desenvolvimento, pois a necessidade hídrica de uma cultura varia de acordo com suas fases fenológicas. Portanto, a cobertura do terreno e sua área foliar (superfície transpirante) variam com a idade da planta (dias após o plantio ou emergência).

Dessa forma, se o ciclo da cultura da cana-de-açúcar de 12 meses for dividido em quatro estádios de desenvolvimento, tem-se:

- Germinação e emergência = ₹1 mês;

- Perfilhamento e estabelecimento da cultura = $\approx 2$ a 3 meses;

- Desenvolvimento da cultura $=\approx 6$ a 7 meses;

- Maturação = ₹2 meses.

Os estádios de germinação e emergência, perfilhamento e estabelecimento da cultura são os mais críticos ao déficit hídrico. No terceiro estádio (desenvolvimento), o déficit hídrico não causa tantos prejuízos à produtividade quanto nos dois primeiros. O quarto estágio (maturação) responde positivamente ao déficit hídrico. Entretanto, o consumo diário de água é maior no terceiro estádio do que nos dois primeiros. Isso ocorre em razão do maior índice de área foliar no terceiro estágio. O teor de açúcar costuma ser afetado adversamente pelo excesso de umidade no estádio de maturação. Neste trabalho foram condensados os estádios de germinação e emergência e perfilhamento e estabelecimento da cultura em um estádio denominado estabelecimento.

Cada um desses estádios, de acordo com a idade da planta (Tabela 6), ou, ainda, com o período de desenvolvimento, apresenta um coeficiente de cultura (Kc) que varia em razão do Índice de Área Foliar (IAF) (DOORENBOS; KASSAM, 1994) e 
do tipo de solo (PEREIRA et al., 2002). Entretanto, seu cálculo pode ser estimado (CAMARGO; PEREIRA, 1990) pela relação:

$$
\mathrm{Kc}=1,2^{*}(\% \text { cobertura do terreno/100). }
$$

Tabela 6 - Valores de Kc para cana-planta e cana-soca.

\begin{tabular}{l|l|l|l|l}
\hline \multicolumn{2}{l|}{ Dias do ciclo (dias) } & $\begin{array}{l}\text { Período de desenvolvimento - } \\
\text { cobertura foliar (\%) }\end{array}$ & \multicolumn{2}{l}{ Coeficiente de cultura (Kc) } \\
\hline Cana-planta & Cana-soca & & Cana-planta & Cana-soca \\
\hline 30 a 60 & 0 a 30 & Do plantio até 25 & 0,40 a 0,60 & 0,55 \\
\hline 30 a 40 & 30 a 60 & 25 a 50 & 0,75 a 0,85 & 0,80 \\
\hline 15 a 25 & 60 a 75 & 50 a 75 & 0,90 a 1,00 & 0,90 \\
\hline 45 a 55 & 75 a 120 & 75 a cobertura completa & 1,00 a 1,20 & 1,00 \\
\hline 180 a 330 & 120 a 300 & Cobertura total do solo & 1,05 a 1,30 & 1,05 \\
\hline 30 a 150 & 300 a 330 & Início de maturação & 0,80 a 1,05 & 0,80 \\
\hline 30 a 60 & 330 a 360 & Maturação & 0,60 a 0,75 & 0,60 \\
\hline
\end{tabular}

Fonte: Doorenbos; Kassam (1994)

No BH de cultura, calcula-se a ETc (evapotranspiração da cultura) em razão da ETP e utilizando o coeficiente de ajuste Kc, denominado Coeficiente de Cultura. É estimada pela equação: ETc=ETo*Kc.

Com as variáveis ETc e CAD, é possível elaborar o $\mathrm{BH}$ de cultura seguindo basicamente o mesmo procedimento do balanço hídrico climatológico sequencial, em diferentes escalas de tempo (mensal, decendial e quinquidial).

3.3.6 - Procedimento metodológico para a relação dos dados climáticos e dados de produtividade

Para determinar a relação do comportamento entre as variáveis chuva e temperatura (variáveis independentes) com a produtividade (dependente das 
variações das variáveis chuva e temperatura) utilizaram-se modelos matemáticos denominados correlação e regressão. A correlação mede a força, a intensidade ou grau de relacionamento entre duas variáveis e a regressão fornece equação que descreve esse relacionamento em termos matemáticos, ou seja, possibilita predizer ou estimar a maneira futura do fenômeno. As equações desses modelos são: equação de regressão linear simples (ajuste da reta), coeficiente de determinação $\left(r^{2}\right)$, coeficiente de correlação $(r)$ e diagrama de dispersão (MAGALHÃES; LIMA, 2008; CRESPO, 2002; SPIEGEL, 1985).

Quanto à análise de regressão linear simples, tem-se que a reta estimada de regressão é $y=a+b x$, onde

$\mathrm{Y}=$ valor calculado na reta de regressão para os valores de $\mathrm{x}$

$a=$ ordenada do intercepto da reta no eixo y

$\mathrm{b}=$ coeficiente angular da reta de regressão

O método dos mínimos quadrados determina que $a$ e $b$ devem ser obtidos de modo que

$$
b=\frac{\sum X Y-\frac{\left(\sum X\right)\left(\sum Y\right)}{n}}{\sum X^{2}-\frac{\left(\sum X\right)^{2}}{n}} \text { e } a=\bar{Y}-b \bar{X} \text { onde } \bar{X}=\frac{\sum X}{n} \text { e } \bar{Y}=\frac{\sum Y}{n}
$$

onde

$n=$ número de elementos da amostra

O coeficiente de determinação deve ser interpretado como a proporção da variação total da variável dependente, que é explicada pela variação da variável independente, além de medir a qualidade do ajuste linear simples, visto que, quanto mais próximo o coeficiente de determinação estiver da unidade, melhor será o ajuste. Apresenta valores sempre positivos e sua expressão é dada por 


$$
R^{2}=\frac{b^{2}\left[\sum X^{2}-\frac{\left(\sum X\right)^{2}}{n}\right]}{\sum Y^{2}-\frac{\left(\sum Y\right)^{2}}{n}} \text { Onde } 0 \leq R^{2} \leq 1
$$

O resultado da análise de correlação linear é expresso na forma de um coeficiente de correlação $(r)$, pois este é um número que identifica o grau de relação linear obtido para os pares de valores de duas variáveis que formam a amostra analisada. Pode admitir valores negativos e positivos.

Valores de $r$ iguais ou próximos de 1 ou -1 indicam que existe uma forte relação entre as variáveis: no primeiro caso a relação é direta, enquanto que no segundo a relação é inversa. Valores próximos de zero significam que existe pouco relacionamento entre as variáveis.

A correlação é classificada de acordo com a intensidade, podendo ser forte, moderada ou fraca. Forte quando o coeficiente for maior que 0,7 , moderada de 0,3 a 0,6 e fraca de 0,0 a 0,3 (CRESPO, 2002).

A correlação pode ser calculada por meio da seguinte fórmula:

$$
r_{x y}=\frac{\sum X Y-\frac{\left(\sum X\right)\left(\sum Y\right)}{n}}{\sqrt{\left[\sum X^{2}-\frac{\left(\sum X\right)^{2}}{n}\right]\left[\sum Y^{2}-\frac{\left(\sum Y\right)^{2}}{n}\right]}} \text { onde }-1 \leq r_{x y} \leq 1
$$

O diagrama de dispersão é um sistema coordenado cartesiano ortogonal, pares ordenados (xi, yi), por meio do qual se obtém uma nuvem de pontos que fornece uma ideia da correlação existente entre as variáveis. Essa relação pode ser positiva ou negativa. Será positiva quando os valores da variável dependente aumentar em decorrência da elevação dos valores da variável independente. 
Negativa quando os valores da variável dependente variar inversamente em relação aos da variável independente, ou seja: à medida que $X$ aumenta, $Y$ diminui.

Para confirmar se a correlação existente entre as variáveis é significativa, avaliou-se o coeficiente de correlação a nível de significância de 10\% e 5\%, ou então a nível de $90 \%$ e $95 \%$ de confiança pelo teste $t$ de Student com n-1 graus de liberdade, sendo o n-1 utilizado para amostras com até 30 elementos, ou seja, $\mathrm{n} \leq 1$. A equação de determinação do nível de significância é expressa por

$$
t=r \sqrt{ } \mathrm{n}-1 / 1-r^{2}
$$

O resultado dessa equação, para confirmar a existência de correlação significativa, deve ser maior que o valor tabelado (MAGALHÕES; LIMA, 2008).

\subsection{7 - Procedimento metodológico para obtenção de anos de El Niño Oscilação Sul} (ENOS)

A série de anos agrícolas com dados de produtividade (1981/82 a 2005/06) foi classificada segundo a metodologia de Podestá et al. (1999), citados por Berlato et al., 2005), que estudaram a relação do ENOS com a produtividade de várias culturas, e da NOAA (2010).

A caracterização das fases ENOS (anos de El Niño, La Niña) consiste na seleção de períodos cuja média móvel de 5 meses de anomalia da temperatura da superfície do mar (TSM), da região equatorial do oceano Pacífico, seja $\leq 0,5^{\circ}$ (El Niño) ou $\geq-0,5^{\circ}$ (La Niña) por, no mínimo, 5 a 6 meses consecutivos. Cada fase ENOS é referente ao período de julho do ano de início do fenômeno a junho do ano seguinte, em razão de este se iniciar no segundo semestre de um ano e acabar no primeiro semestre do ano seguinte (PODESTÁ, 1999; NOAA, 2010). Esse período é bem próximo do ciclo da cana-de-ano, ou seja, de 12 meses, sendo esta plantada, geralmente, em setembro de um ano e colhida em agosto do ano seguinte. A 
correlação entre o Índice de Oscilação Sul (IOS) e os desvios do total mensal de chuva para a região de Maringá, PR, série de 21 anos (1976 a 1996), mostra que o IOS de janeiro reflete a alteração do total de chuva de abril e maio. Indica assim um atraso de 3 a 4 meses entre a ocorrência de uma anomalia de temperatura e a pressão no Pacífico e sua manifestação nas regiões Norte e Noroeste desse estado (GALVANI, KLOSOWSKI, 1998).

De acordo com a série de anos agrícolas deste estudo (1981/82 a 2005/06), os anos considerados de El Niño foram os de 1982/83, 1986/87, 1987/88, 1991/92, 1992/93, 1993/94, 1994/95, 1997/98, 2002/03 e 2004/05. Os anos com episódios de La Niña são os de 1988/89, 1995/96, 1998/99, 1999/00. E anos Neutros os de 1981/82, 1983/84, 1985/86, 1989/90, 1990/91, 1996/97, 2000/01, 2001/02, 2003/04 e $2005 / 06$.

Dessa forma, a série dos anos agrícolas de 1981/82 a 2005/06 foi desmembrada em períodos de anos de evento El Niño, La Niña e Neutro. O período de El Niño é composto por 10 anos. O período de La Niña por 5 anos e o Neutro por 10 anos. Dentre esses três episódios, a série de tempo La Niña é a mais reduzida, embora a técnica estatística utilizada trabalhe com amostras pequenas. Utilizaramse os dados de cada um desses períodos para correlacionar dados climáticos e dados de produtividade. 


\section{4 - RESULTADOS E DISCUSSÕES}

\section{1 - Quantificação da cultura da cana-de-açúcar no território nacional e no estado do Paraná no período de 1990 a 2006}

No contexto brasileiro, a cultura da cana-de-açúcar vem apresentando tendência de expansão em áreas principalmente sem tradição dessa cultura, fato verificado pelo aumento em área plantada nas regiões Sul, Centro-Oeste e interior do Sudeste, com aumento médio ao ano de $17 \mathrm{mil}$ ha, $22 \mathrm{mil}$ ha e $99 \mathrm{mil} \mathrm{ha}$, respectivamente. Na região Nordeste, área tradicional dessa cultura desde o século $\mathrm{XVI}$, houve redução média de 22 mil ha ao ano (Figura 23). Em termos de valores médios de área plantada, essas três regiões tiveram valores de 345 milhões, 370 milhões e 2.970 milhões hectares.

Do inicio do período, 1990, até o final, 2006, o Brasil passou de 4,32 milhões para 6,2 milhões de hectares plantados com essa cultura. Ou seja, um aumento de $43,5 \%$ no período, e um aumento médio em torno de $2,6 \%$ ao ano de área plantada, com média de 4,917 milhões de hectares ao ano (Tabela 9).

Com relação à produção do Brasil, esta teve aumento de $74 \%$ no período, passando de 263 milhões de toneladas em 1990 para 457 milhões de toneladas em 2006. A média de produção girou em torno de 335 milhões de toneladas. Quanto à média da produtividade, esta foi de 68 ton/ha, sendo de 61,4 ton/ha em 1990 e de 74,4 ton/ha no final do período (Tabela 9).

Para as regiões brasileiras, em termos de área plantada e produção de canade-açúcar, a região Sudeste, seguida pela Nordeste, foi a que apresentou os maiores valores; na sequência vêm as regiões Centro-Oeste e Sul.

Dessa forma, a região Sudeste ocupa $60 \%$ da área plantada e a Nordeste $17 \%$. Após o ano de 2000, a região Centro-Oeste superou os valores de área plantada da região Sul. Para o período, todas as regiões tiveram crescimento, com exceção da região Nordeste, que teve decréscimo em 10 dos 17 anos do período. Essa redução foi em torno de 360 mil ha em área plantada, e de 8,5 milhões de toneladas em produção, no período. As outras três regiões citadas tiveram, no período, aumento em área plantada e em produção em torno de 1.303 milhões de ha 
e 140 milhões de toneladas (Sudeste); 353 mil ha e 30 milhões de toneladas (Centro-Oeste); e 246 mil ha e 22 milhões de toneladas (Sul) (Figura 23 A e B).

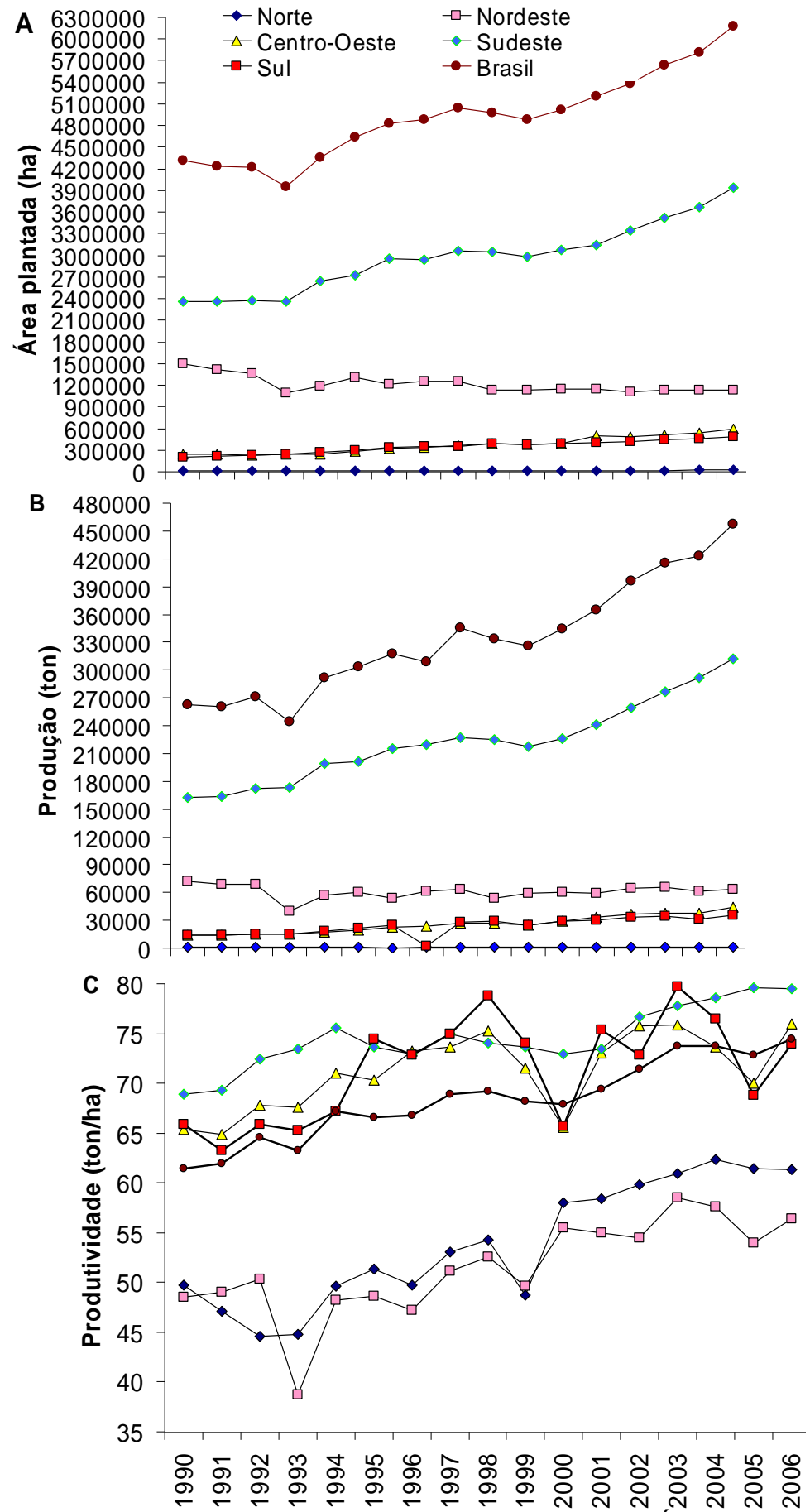

Figura 23 - Dados da cultura da cana-de-açúcar no Brasil e regiões, - A=Área plantada, B=Produção e C=Produtividade, período de 1990 a 2006 (Fonte: IBGE/PAM - Produção Agrícola Municipal, 2008). Org.: Domingues, I.A.S. (2007). 
Quanto aos valores médios da produtividade (Figura $23 \mathrm{C}$ ), as regiões brasileiras apresentaram os seguintes valores: a região Sudeste, que abrangeu em torno de $66 \%$ da área plantada do território do Brasil, teve produtividade média, no ano de 1990, de 68,9 ton/ha, sendo esta a menor do período, e a maior foi de 79,6 ton/ha, em 2006; em segundo lugar esteve a região Sul, onde a menor produtividade foi no ano de 1991, com 63,2 ton/ha, e a maior de 79,7 ton/ha, em 2003; a região Centro-Oeste ficou em terceiro lugar com 64,9 ton/ha em 1990, e 75,92 ton/ha em 2006; na sequência vieram as regiões Norte e Nordeste, com valores de 44,6 ton/ha em 1992 e 62,3 ton/ha em 2004, e 38,7 ton/ha em 1993 e 58,5 ton/ha em 2003. Quanto aos valores médios da produtividade, teve-se, em ordem da maior para a menor região, a Sudeste, a Sul e a Centro-Oeste, com 74,9\%, 72,2\% e 69,6\% respectivamente.

Analisando comparativamente esses dados, do ponto de vista da produtividade do estado de maior destaque de cada região, os números se diferenciam. Pertencente à região Sudeste, o estado de São Paulo é o maior em produtividade, com média de 78,78 ton/ha; em segundo lugar vem o estado do Paraná, na região Sul, com 78,50 ton/ha; e em terceiro Goiás, na região CentroOeste, com 71,48 ton/ha (Tabela 1 ).

Quanto à produção, o estado de São Paulo também está em primeiro lugar, com valores médios aproximados em torno de 194 milhões de toneladas, seguido do Paraná, com 23 milhões, e Goiás, com 10 milhões de toneladas.

Os valores por estado, quando comparados com os da sua região, mostram situações bastante peculiares a cada estado. O estado de São Paulo, que apresenta valores mais expressivos que os demais, detém $83 \%$ da área plantada, $87 \%$ da produção e a maior produtividade, média de 81,9 ton/ha, entre os quatro estados. Em segundo lugar vem o estado de Minas Gerais, com 10\% da área, $8 \%$ da produção e média da produtividade de 64 ton/ha.

Dos três estados da região Sul, o Paraná é segundo maior em área plantada, produção e rendimento, com $86 \%$ de área plantada, $93,5 \%$ da produção e produtividade média de 78,5 ton/ha. O estado de Goiás, um dos 4 estados da região Centro-Oeste, com 38,7\% da área plantada, 39,7\% da produção e valor médio 71,4 ton/ha de produtividade. No Nordeste do país, o estado do Piauí tem a menor área, 
11.674ha, e a menor produção 705.458ton, embora com maior produtividade entre os 9 estados, 60,4 ton/ha. O estado de Alagoas tem maior área plantada e produção, com $36,4 \%$ e $39,8 \%$ da área total, ficando em terceiro lugar em produtividade, 54,6 ton/ha. Na região com a menor área plantada do país, a região Norte, o estado do Pará se destaca dos 6 demais estados em área, em produção e em produtividade, $49 \%$ da área total, $54 \%$ da produção total e 54 ton/ha respectivamente (Tabela 7 ).

Dentro desse contexto, destaca-se a cultura da cana-de-açúcar no Paraná, objeto deste estudo. Dentre todos os estados brasileiros, esse é o segundo com produtividade mais elevada. Assim, fez-se necessária uma análise espaço-temporal mais pormenorizada da cultura da cana-de-açúcar. 
Tabela 7 - Dados anuais de Produtividade (ton/ha); dados do período de Produção (ton) e área plantada (ha) com cana-de-açúcar, 1990 a 2006 no território brasileiro.

\begin{tabular}{|c|c|c|c|c|c|c|c|c|c|c|c|c|c|c|c|c|c|c|c|c|}
\hline Região/UF & 1990 & 1991 & 1992 & 1993 & 1994 & 1995 & 1996 & 1997 & 1998 & 1999 & 2000 & 2001 & 2002 & 2003 & 2004 & 2005 & 2006 & Produt & Prod & Área \\
\hline Norte & 49,8 & 47,1 & 44,6 & 44,8 & 49,7 & 51,3 & 49,8 & 53,1 & 54,3 & 48,7 & 58,0 & 58,4 & 59,8 & 60,9 & 62,3 & 61,4 & 61,4 & 49,0 & 795.289 & 16.216 \\
\hline Acre & 23,7 & 23,4 & 22,7 & 26,5 & 26,1 & 26,3 & 25,2 & 30,3 & 31,2 & 35,1 & 31,4 & 41,1 & 37,5 & 34,8 & 35,5 & 35,8 & 36,2 & 27,1 & 14.894 & 549 \\
\hline Amapá & 20,0 & 20,0 & 18,0 & 16,0 & 15,0 & 18,0 & 18,8 & 19,3 & 23,5 & 25,9 & 22,4 & 22,4 & 20,6 & 21,5 & 23,7 & 24,4 & 27,6 & 21,8 & 1.263 & 58 \\
\hline Amazonas & 48,4 & 34,6 & 25,0 & 34,5 & 36,3 & 34,1 & 13,0 & 15,0 & 48,2 & 51,5 & 53,2 & 57,6 & 57,6 & 61,3 & 61,5 & 59,2 & 58,6 & 49,4 & 156.385 & 3.169 \\
\hline Pará & 55,1 & 54,6 & 52,8 & 53,9 & 56,8 & 59,8 & 57,8 & 63,2 & 65,9 & 57,6 & 72,6 & 65,7 & 69,3 & 69,3 & 69,4 & 69,2 & 70,6 & 54,0 & 430.417 & 7.966 \\
\hline Rondônia & 49,7 & 48,6 & 48,5 & 44,1 & 42,4 & 43,2 & 41,6 & 35,6 & 36,3 & 36,9 & 46,1 & 37,7 & 74,9 & 71,3 & 71,4 & 70,3 & 68,0 & 53,9 & 26.777 & 497 \\
\hline Roraima & 49,8 & 12,8 & 11,7 & 0,0 & 0,0 & 0,0 & 0,0 & 0,0 & 2,3 & 2,9 & 2,9 & 3,1 & 3,0 & 3,1 & 3,4 & 3,4 & 3,4 & 2,7 & 967 & 354 \\
\hline Tocantins & 46,9 & 42,3 & 38,3 & 38,1 & 49,0 & 48,3 & 43,8 & 42,4 & 40,8 & 40,9 & 42,0 & 57,8 & 54,9 & 57,1 & 58,8 & 58,6 & 54,7 & 0,3 & 967 & 3.706 \\
\hline Nordeste & 48,5 & 49,0 & 50,4 & 38,7 & 48,2 & 48,7 & 47,2 & 51,2 & 52,6 & 49,6 & 55,4 & 54,9 & 54,5 & 58,5 & 57,6 & 54,0 & 56,4 & 49,9 & 60.688 .167 & 1.215 .220 \\
\hline Alagoas & 46,8 & 45,9 & 50,6 & 40,1 & 49,6 & 48,0 & 48,0 & 55,2 & 61,9 & 59,5 & 62,0 & 63,0 & 57,5 & 65,5 & 62,1 & 58,3 & 58,4 & 54,6 & 24.155 .590 & 442.095 \\
\hline Bahia & 43,1 & 44,7 & 45,9 & 49,1 & 50,5 & 53,5 & 53,5 & 53,3 & 52,0 & 53,3 & 53,2 & 54,7 & 55,3 & 56,7 & 57,6 & 61,4 & 59,0 & 52,5 & 4.378 .666 & 83.413 \\
\hline Ceará & 43,2 & 44,1 & 43,5 & 35,0 & 45,3 & 46,7 & 45,5 & 48,6 & 45,8 & 50,9 & 51,9 & 51,4 & 49,1 & 52,3 & 51,9 & 50,9 & 55,6 & 46,7 & 1.897 .345 & 40.599 \\
\hline Maranhão & 54,6 & 53,9 & 48,2 & 52,7 & 52,8 & 55,7 & 53,1 & 59,7 & 51,8 & 52,5 & 55,7 & 35,8 & 60,9 & 61,0 & 61,7 & 62,0 & 58,7 & 54,5 & 1.517 .786 & 27.861 \\
\hline Paraíba & 52,9 & 52,4 & 51,9 & 19,8 & 40,1 & 44,8 & 38,8 & 40,7 & 32,8 & 38,2 & 43,8 & 49,9 & 50,4 & 54,4 & 54,5 & 54,5 & 52,2 & 45,0 & 5.257 .730 & 116.858 \\
\hline Pernambuco & 48,8 & 48,8 & 51,6 & 51,6 & 48,2 & 49,5 & 46,8 & 49,4 & 48,8 & 38,0 & 49,8 & 47,1 & 50,6 & 51,5 & 52,3 & 46,6 & 52,9 & 44,5 & 18.448 .654 & 414.379 \\
\hline Piauí & 80,8 & 77,7 & 48,7 & 48,0 & 60,1 & 61,8 & 62,1 & 52,9 & 53,6 & 57,5 & 54,6 & 56,8 & 53,2 & 54,7 & 58,2 & 65,0 & 62,7 & 60,4 & 705.458 & 11.674 \\
\hline R.G. Norte & 43,8 & 49,9 & 47,2 & 27,6 & 43,7 & 43,5 & 43,6 & 43,5 & 41,4 & 37,4 & 54,8 & 50,4 & 58,1 & 64,3 & 62,2 & 61,0 & 61,0 & 48,3 & 2.508 .481 & 51.919 \\
\hline Sergipe & 57,3 & 55,1 & 53,4 & 53,8 & 58,5 & 57,2 & 54,9 & 60,1 & 60,6 & 60,7 & 64,3 & 64,7 & 66,3 & 63,9 & 67,3 & 66,2 & 61,4 & 58,0 & 1.530 .348 & 26.382 \\
\hline Centro-Oeste & 65,4 & 64,9 & 67,8 & 67,6 & 71,0 & 70,3 & 73,3 & 73,7 & 75,2 & 71,6 & 65,6 & 73,0 & 75,8 & 75,9 & 73,6 & 70,0 & 75,9 & 69,6 & 25.752 .927 & 369.999 \\
\hline Dist. Federal & 0,0 & 48,5 & 50,0 & 38,7 & 46,4 & 69,6 & 21,7 & 66,5 & 47,4 & 46,9 & 44,5 & 44,2 & 41,4 & 45,1 & 46,6 & 51,5 & 53,7 & 48,1 & 13.633 & 283 \\
\hline Goiás & 70,4 & 70,0 & 72,9 & 73,3 & 74,8 & 73,6 & 78,8 & 78,7 & 79,5 & 71,9 & 73,0 & 78,9 & 80,5 & 78,3 & 79,4 & 79,6 & 81,9 & 71,5 & 10.231 .948 & 143.144 \\
\hline Mato Grosso & 59,9 & 60,6 & 61,7 & 61,4 & 70,0 & 70,2 & 71,4 & 74,6 & 72,3 & 69,6 & 62,7 & 66,8 & 71,6 & 74,6 & 69,1 & 61,2 & 67,0 & 67,3 & 8.954 .229 & 133.009 \\
\hline M.G.Sul & 62,3 & 60,2 & 65,5 & 65,8 & 65,6 & 65,8 & 68,8 & 65,7 & 73,5 & 74,3 & 59,0 & 75,8 & 76,5 & 74,9 & 73,1 & 69,5 & 78,6 & 70,0 & 6.553 .920 & 93.579 \\
\hline Sudeste & 68,9 & 69,4 & 72,5 & 73,5 & 75,6 & 73,7 & 73,0 & 74,9 & 74,1 & 73,6 & 72,9 & 73,4 & 76,6 & 77,8 & 78,6 & 79,6 & 79,5 & 74,9 & 222.516 .419 & 2.970 .760 \\
\hline Esp. Santo & 35,5 & 46,3 & 54,3 & 56,1 & 58,6 & 51,4 & 53,5 & 51,8 & 51,2 & 51,2 & 54,1 & 53,2 & 62,7 & 65,2 & 67,9 & 65,9 & 65,7 & 56,4 & 2.636 .818 & 46.719 \\
\hline M.Gerais & 58,8 & 63,8 & 63,7 & 60,4 & 61,9 & 62,5 & 53,9 & 58,3 & 60,5 & 62,6 & 64,3 & 64,5 & 65,6 & 68,6 & 72,7 & 72,7 & 74,8 & 64,6 & 19.050 .010 & 295.142 \\
\hline Rio Janeiro & 27,2 & 41,7 & 40,5 & 41,3 & 41,4 & 45,1 & 44,7 & 44,6 & 44,9 & 44,6 & 44,6 & 31,4 & 45,0 & 44,7 & 50,7 & 44,9 & 45,0 & 41,8 & 7.120 .736 & 170.452 \\
\hline São Paulo & 76,1 & 73,5 & 77,0 & 78,4 & 80,1 & 77,5 & 77,1 & 79,3 & 77,9 & 77,2 & 76,1 & 77,5 & 79,9 & 80,9 & 81,1 & 82,6 & 81,9 & 78,8 & 193.685 .073 & 2.458 .448 \\
\hline Sul & 65,9 & 63,2 & 65,9 & 65,2 & 67,2 & 74,4 & 72,9 & 75,0 & 78,8 & 74,1 & 65,7 & 75,3 & 72,8 & 79,7 & 76,5 & 68,8 & 74,0 & 72,3 & 24.918 .599 & 344.886 \\
\hline Paraná & 73,6 & 70,9 & 73,0 & 72,0 & 73,9 & 79,9 & 82,3 & 81,9 & 85,8 & 80,1 & 70,9 & 81,1 & 78,3 & 85,4 & 81,7 & 73,5 & 78,4 & 78,5 & 23.310 .408 & 296.958 \\
\hline Sta Catarina & 29,3 & 26,7 & 31,1 & 31,3 & 30,8 & 30,9 & 23,3 & 29,7 & 31,7 & 31,8 & 29,9 & 33,4 & 32,6 & 35,3 & 32,1 & 28,0 & 35,1 & 30,6 & 979.187 & 32.035 \\
\hline \multirow[t]{2}{*}{ R.G.Sul } & 59,7 & 51,9 & 54,9 & 54,9 & 52,4 & 47,5 & 19,9 & 25,8 & 30,0 & 31,5 & 31,9 & 37,5 & 37,7 & 38,8 & 36,6 & 36,0 & 38,5 & 39,6 & 629.003 & 15.892 \\
\hline & 61,5 & 62,0 & 64,6 & 63,3 & 67,2 & 66,6 & 66,8 & 68,9 & 69,2 & 68,1 & 67,9 & 69,4 & 71,4 & 73,7 & 73,7 & 72,9 & 74,4 & 68,1 & 334.671 .401 & 4.917 .081 \\
\hline
\end{tabular}

Org.: Domingues, I.A.S. (2007). Fonte: SIDRA - IBGE - PAM (Produção agrícola municipal), (2007). 


\section{2 - Distribuição espacial da cultura da cana-de-açúcar no estado do Paraná e sua evolução temporal no período de 1990 a 2006}

\subsection{1 - Análise por mesorregiões}

O estado do Paraná é um dos três estados que compõem a região Sul do Brasil. Territorialmente é dividido, segundo o IBGE, em 10 mesorregiões, das quais quatro se destacam no cultivo da cana-de-açúcar: Norte Central, Norte Pioneiro, Noroeste e Centro-Ocidental.

Esse estado tinha no ano de 1990 (ano que culminou com cortes efetuados pelo governo nos investimentos do PROALCOOL) uma área plantada com cana-deaçúcar de 159.420ha e de 432.815ha em 2006, o que significa aumento de 273.395ha nesse período de 17 anos. Desse total, essas quatro mesorregiões detiveram 97,7\% da área plantada: a região Norte Central com valor médio de 102.859ha; a Noroeste 99.596ha; a região Norte Pioneiro com 68.210ha e; a CentroOcidental com 19.759ha (Tabela 8).

No que se refere à evolução espacial, apenas a mesorregião Noroeste teve aumento sucessivo em área plantada durante todos os anos. Os valores em área plantada tiveram o seguinte comportamento: para início do período o valor era em torno de 31 mil ha e em 2006 foi de 190 mil ha, com valor médio de 99,6 mil ha. Dentro desse contexto, o ano de 2000 foi uma exceção, havendo uma redução da área plantada de 3.801ha. As três demais regiões tiveram aumento médio em área no período de 11,5 mil ha (centro ocidental), 27 mil ha (Norte Pioneiro) e 66 mil ha (Norte Central), (Tabela 8, Figura 24).

Para os dez primeiros anos do período, a mesorregião com maior área plantada foi a Norte Central, seguida pela Norte Pioneiro. A partir do ano de 1999, a região Noroeste passou à frente, chegando em 2006 com uma diferença em torno de 57 mil ha e 119 mil ha, respectivamente (Figura 24).

As maiores variações em área plantada se deram na região Norte Pioneiro, para os anos de 1993, 2005 e 2006, em relação aos anos que os antecederam. Para 
esses três anos, a redução foi em torno de 6 mil ha. No ano de 2000, houve redução em área principalmente para aquelas quatro mesorregiões (Figura 24).

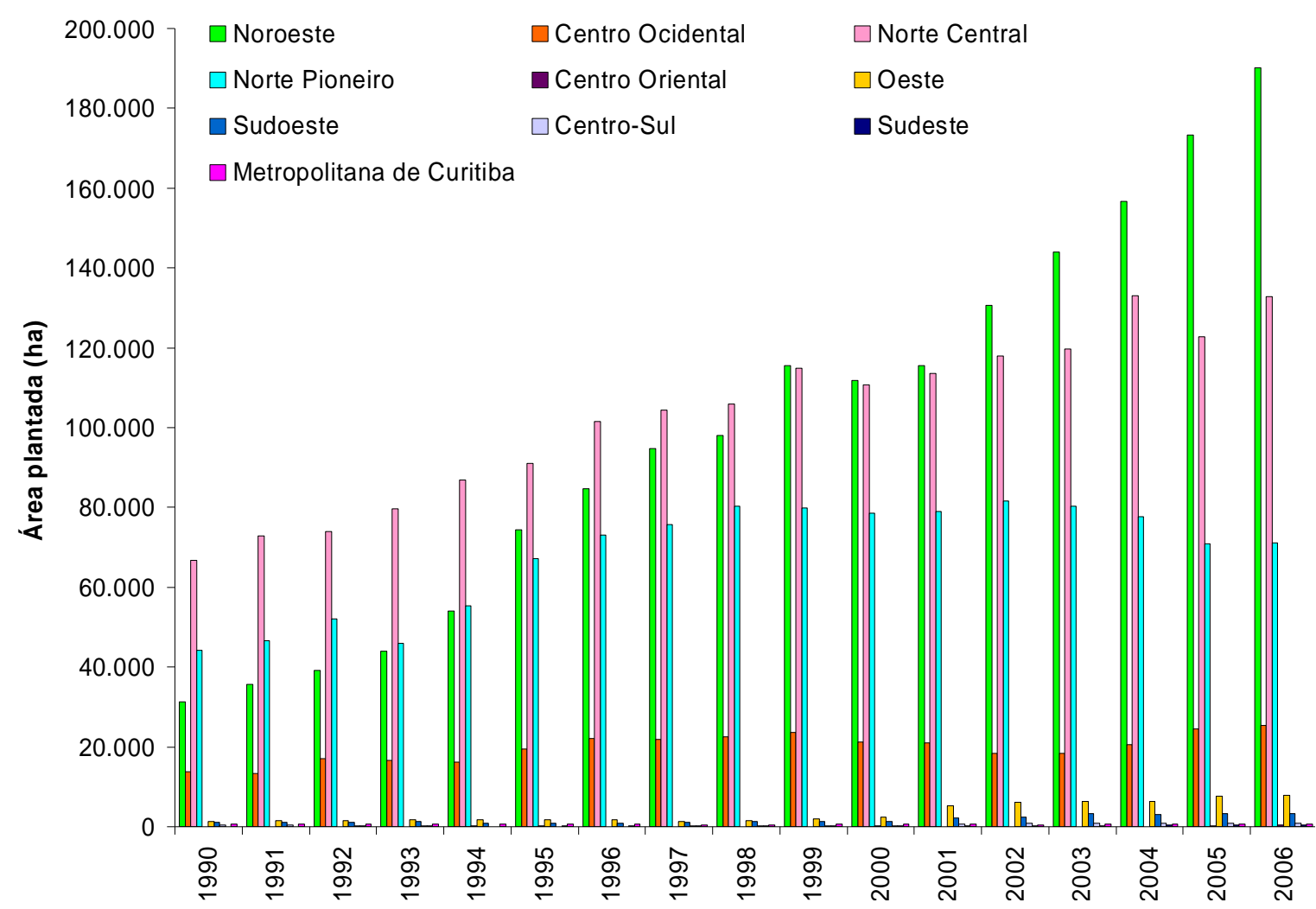

Figura 24 - Área plantada com a cultura da cana por mesorregião paranaense no período de 1990 a 2006. Org.: Domingues, I.A.S. (2007).

Considerando todas as mesorregiões, constatou-se que o valor médio de produtividade do período foi de aproximadamente 70 ton/ha. Para efeito deste estudo, optou-se por trabalhar as regiões que apresentaram produtividade em torno ou superior à da média geral.

O procedimento anual dos valores médios do período para a produtividade média da cana mostrou valores em torno de 32 ton/ha a 81,75 ton/ha (Tabela 8 e 9 e Figura 25). Para as quatro mesorregiões, onde o cultivo da cana é maior, os valores médios do período foram acima de 77 ton/ha. Na mesorregião Norte Pioneiro o valor total da produtividade foi o mais alto, 81,75 ton/ha; a Norte Central e a centro ocidental ficaram em segundo, com 79 ton/ha; seguida da Noroeste com 77,51 
ton/ha. Esses valores, juntamente com os de área plantada, confirmam as regiões de domínio da cana-de-açúcar no Paraná (Tabela 9). 
Tabela 8 - Produtividade média (ton/ha) e área plantada (ha) da cultura da cana-de-açúcar por mesorregião geográfica paranaense, de 1990 a 2006.

\begin{tabular}{|c|c|c|c|c|c|c|c|c|c|c|c|c|c|c|c|c|c|}
\hline Mesorregião & 1990 & 1991 & 1992 & 1993 & 1994 & 1995 & 1996 & 1997 & 1998 & 1999 & 2000 & 2001 & 2002 & 2003 & 2004 & 2005 & 2006 \\
\hline $\begin{array}{c}\text { Noroeste } \\
\text { Produtividade }\end{array}$ & 73,64 & 66,44 & 70,28 & 67,17 & 76,83 & 80,15 & 86,58 & 84,83 & 86,94 & 78,94 & 66,92 & 77,02 & 75,37 & 81,28 & 81,03 & 72,74 & 76,54 \\
\hline Área plantada & 31.206 & 35.754 & 39.151 & 44.036 & 53.943 & 74.434 & 84.652 & 94.674 & 97.947 & 115.517 & 111.716 & 115.431 & 130.739 & 144.004 & 156.656 & 173.211 & 190.068 \\
\hline $\begin{array}{l}\text { Centro-Ocidental } \\
\text { Produtividade } \\
\end{array}$ & 72,96 & 72,42 & 78,51 & 82,71 & 74,76 & 79,82 & 77,86 & 79,871 & 82,88 & 70,44 & 66,41 & 77,85 & 74,31 & 94,03 & 90,10 & 77,05 & 91,83 \\
\hline Área plantada & 13.788 & 13.263 & 17.104 & 16.559 & 16.138 & 19.425 & 22.117 & 21.855 & 22.488 & 23.559 & 21.170 & 21.035 & 18.489 & 18.474 & 20.660 & 24.449 & 25.329 \\
\hline $\begin{array}{l}\text { Norte Central } \\
\text { Produtividade }\end{array}$ & 76,00 & 68,43 & 74,45 & 71,16 & 73,50 & 82,57 & 84,03 & 83,46 & 87,39 & 79,92 & 71,33 & 83,26 & 80,49 & 88,96 & 81,78 & 73,61 & 77,64 \\
\hline Área plantada & 66.677 & 72.928 & 73.867 & 79.667 & 86.943 & 90.968 & 101.630 & 104.408 & 105.983 & 114.854 & 110.771 & 113.560 & 117.900 & 119.611 & 133.082 & 122.852 & 132.908 \\
\hline $\begin{array}{l}\text { Norte Pioneiro } \\
\text { Produtividade }\end{array}$ & 72,45 & 79,92 & 73,506 & 76,74 & 73,25 & 78,20 & 78,30 & 78,20 & 85,19 & 87,05 & 79,06 & 88,92 & 84,33 & 91,04 & 85,95 & 78,83 & 85,32 \\
\hline Área plantada & 44.223 & 46.683 & 52.000 & 45.906 & 55.321 & 67.234 & 73.082 & 75.761 & 80.207 & 79.927 & 78.593 & 78.971 & 81.559 & 80.309 & 77.631 & 70.958 & 71.213 \\
\hline $\begin{array}{c}\text { Centro Oriental } \\
\text { Produtividade }\end{array}$ & 30,00 & 20,00 & 20,00 & 29,43 & 35,49 & 30,00 & 30,00 & 50,00 & 50,00 & - & 40,00 & 50,00 & 50,00 & 50,00 & 50,00 & 50,00 & 81,82 \\
\hline Área plantada & 3 & 53 & 53 & 53 & 193 & 123 & 100 & 100 & 100 & - & 120 & 25 & 21 & 25 & 32 & 112 & 330 \\
\hline $\begin{array}{c}\text { Oeste } \\
\text { Produtividade } \\
\end{array}$ & 52,06 & 51,66 & 48,88 & 48,71 & 49,27 & 48,34 & 44,71 & 39,26 & 39,90 & 38,11 & 37,60 & 47,26 & 49,95 & 47,41 & 46,62 & 50,19 & 51,34 \\
\hline Área plantada & 1.286 & 1.435 & 1.490 & 1.665 & 1.775 & 1.829 & 1.805 & 1.301 & 1.469 & 1.960 & 2.495 & 5.202 & 6.135 & 6.405 & 6.445 & 7.708 & 7.804 \\
\hline $\begin{array}{c}\text { Sudoeste } \\
\text { Produtividade } \\
\end{array}$ & 41,99 & 41,03 & 44,88 & 41,07 & 39,65 & 43,10 & 43,44 & 52,54 & 52,55 & 48,91 & 43,89 & 46,02 & 45,22 & 46,13 & 46,15 & 37,33 & 42,34 \\
\hline Área plantada & 1.137 & 1.122 & 1.198 & 1.270 & 882 & 902 & 884 & 1.171 & 1.237 & 1.375 & 1.205 & 2.167 & 2.450 & 3.252 & 3.144 & 3.249 & 3.284 \\
\hline $\begin{array}{c}\text { Centro-Sul } \\
\text { Produtividade } \\
\end{array}$ & 42,25 & 37,10 & 28,46 & 41,48 & 45,67 & 44,58 & 49,63 & 50,09 & 49,84 & 50,59 & 47,12 & 47,85 & 48,13 & 47,61 & 55,29 & 50,90 & 51,81 \\
\hline Área plantada & 525 & 475 & 321 & 305 & 34 & 24 & 108 & 159 & 243 & 211 & 260 & 740 & 907 & 889 & 956 & 952 & 890 \\
\hline $\begin{array}{c}\text { Sudeste } \\
\text { Produtividade }\end{array}$ & 40,00 & 40,00 & 12,96 & 23,29 & 40,00 & 22,44 & 30,67 & 30,35 & 37,19 & 39,78 & 36,60 & 33,96 & 37,10 & 35,81 & 35,80 & 34,47 & 32,40 \\
\hline Área plantada & 25 & 25 & 30 & 125 & 50 & 205 & 186 & 181 & 240 & 319 & 230 & 217 & 264 & 310 & 331 & 339 & 339 \\
\hline $\begin{array}{c}\text { Metrop. Curitiba } \\
\text { Produtividade }\end{array}$ & 38,05 & 38,44 & 38,55 & 39,04 & 39,36 & 39,34 & 37,56 & 39,00 & 39,13 & 35,30 & 37,19 & 41,82 & 39,13 & 42,03 & 33,88 & 34,24 & 36,71 \\
\hline $\begin{array}{l}\text { Área plantada } \\
\text { Total área }\end{array}$ & $\begin{array}{r}550 \\
159,42 \\
\end{array}$ & \begin{tabular}{r|}
558 \\
172,30 \\
\end{tabular} & $\begin{array}{r}558 \\
185,97 \\
\end{array}$ & \begin{tabular}{r|}
623 \\
190,21 \\
\end{tabular} & $\begin{array}{r}577 \\
215,86\end{array}$ & $\begin{array}{r}623 \\
255,77 \\
\end{array}$ & $\begin{array}{r}583 \\
285,18 \\
\end{array}$ & $\begin{array}{r}460 \\
300,07 \\
\end{array}$ & $\begin{array}{r}480 \\
310,39 \\
\end{array}$ & $\begin{array}{r}688 \\
338,41 \\
\end{array}$ & \begin{tabular}{r|}
605 \\
327,17 \\
\end{tabular} & \begin{tabular}{r|}
665 \\
338,01 \\
\end{tabular} & \begin{tabular}{r|}
410 \\
358,87 \\
\end{tabular} & \begin{tabular}{r|}
560 \\
373,84 \\
\end{tabular} & $\begin{array}{r}590 \\
399,53 \\
\end{array}$ & \begin{tabular}{r|}
690 \\
404,52 \\
\end{tabular} & $\begin{array}{r}665 \\
432,82 \\
\end{array}$ \\
\hline
\end{tabular}

Org.: Domingues, I.A.S. (2007).

Fonte: SIDRA - IBGE - PAM - Produção Agrícola Municipal, (2007). 
Tabela 9 - Dados médios da área plantada e da produção e produtividade de cana-de-açúcar para o período de 1990-2006 por mesorregião no estado do Paraná.

\begin{tabular}{l|r|r|r}
\hline $\begin{array}{l}\text { Mesorregiões } \\
\text { paranaenses }\end{array}$ & Área plantada (ha) & Produção (ton) & $\begin{array}{c}\text { Produtividade média } \\
\text { (ton/ha) }\end{array}$ \\
\hline Noroeste & $99.596,41$ & $7.719 .744,00$ & 77,51 \\
\hline Centro-Ocidental & $19.758,94$ & $1.567 .491,00$ & 79,33 \\
\hline Norte Central & $102.859,35$ & $8.150 .496,00$ & 79,24 \\
\hline Norte Pioneiro & $68.210,47$ & $5.576 .110,00$ & 81,75 \\
\hline Centro-Oriental & 90,19 & $4.366,00$ & 48,40 \\
\hline Oeste & $3.424,06$ & $163.161,00$ & 47,65 \\
\hline Sudoeste & $1.760,53$ & $77.920,00$ & 44,26 \\
\hline Centro-Sul & 470,53 & $22.420,00$ & 47,65 \\
\hline Sudeste & 212,71 & $6.857,00$ & 32,24 \\
\hline Metropolitana Curitiba & 580,59 & $22.100,00$ & 38,07 \\
\hline Total/média & $296.958,50$ & $23.310 .408,00$ & 78,50 \\
\hline Org:Doming
\end{tabular}

Org.: Domingues, I.A.S. (2007). Fonte: IBGE/PAM - Produção Agrícola Municipal (2008).

Dessa forma, a cultura da cana-de-açúcar no estado do Paraná, para o período de 1990 a 2006, ainda no que se refere à produtividade, se destaca nas quatro mesorregiões citadas. Essa área compreende a região Norte, de domínio dos solos originados do basalto; a região Centro-Ocidental; e a região Noroeste, onde predomina solo de origem da Formação Caiuá (Tabela 8, Figura 24). A distribuição das maiores produtividades se deu da seguinte forma em anos alternados: mesorregião Norte Pioneiro, com seis anos (1991, 1999, 2000 a 2002 e 2005); Centro Ocidental, com cinco anos (1992, 1993, 2003, 2004 e 2006); Norte Central (1990, 1995 e 1998) e Noroeste com três anos (1994, 1996 e 1997), (Figura 25). 


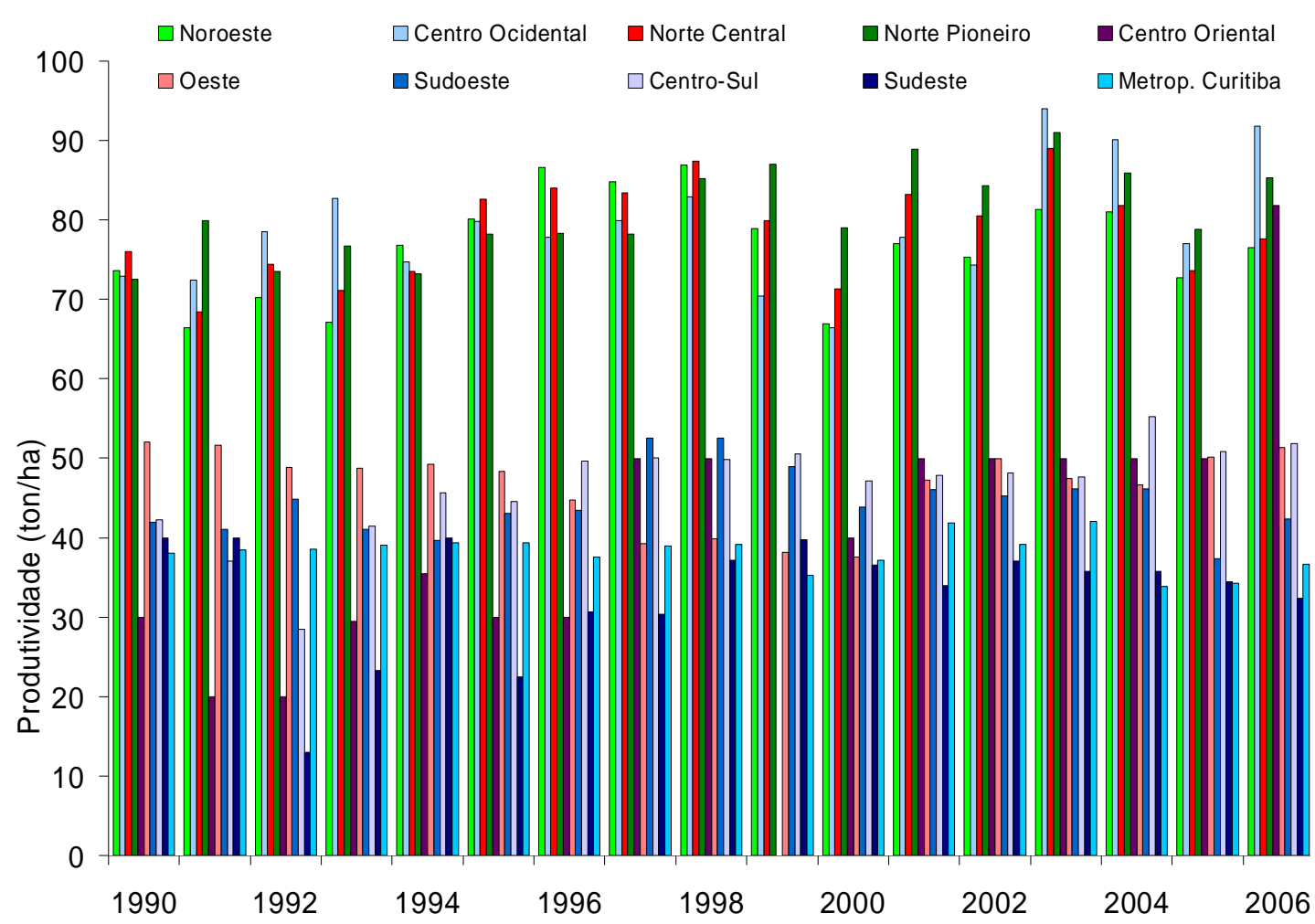

Figura 25 - Produtividade média anual da cana nas mesorregiões paranaenses no período de 1990 a 2006.

Org.: Domingues, I.A.S. (2008).

A produtividade anual para essas quatro regiões variou com valores aproximados entre 70 ton/ha e 94 ton/ha (Tabela 8). Nas demais regiões os valores variaram de 20 ton/ha a 52 ton/ha, com exceção do ano de 2006 para a região Centro-Oriental, quando atingiu aproximadamente 81 ton/ha. (Tabela 8).

Ainda conforme a Tabela 9, a relação de produtividade e área plantada não significou evolução positiva no valor do rendimento. Para muitos dos anos houve aumento da área plantada e diminuição da produtividade. Em alguns poucos casos, como nas mesorregiões Norte Pioneiro e Centro-Ocidental, ocorreu redução da área e aumento de produtividade para o ano de 1993, em relação ao ano anterior, bem como para a mesorregião Noroeste, no período de 2004 para 2005.

No caso das regiões em que houve queda da produtividade, 0 baixo rendimento pode estar mais relacionado às questões climáticas. Pois, de acordo com estudo pluviométrico realizado por Souza e Galvani (2008) para a microrregião de Campo Mourão (localizada na mesorregião Centro-Ocidental) e de Maringá (pertencente à mesorregião Norte Central), os anos de 1999, 2000, 2001 e 2005, 
principalmente, foram anos com totais de chuvas fora do padrão. E, conforme verificado, a maioria das mesorregiões apresentaram redução na produtividade para esses referidos anos (Tabela 8), dentre os quais se destaca o de 2005, quando houve redução de produtividade em todas as regiões, com exceção da mesorregião Oeste paranaense. Essas questões podem se tornar mais evidenciadas quando estudadas em escala municipal, conforme mostrado no item pertinente mais adiante.

Com relação à produção da cana-de-açúcar, constatou-se que a mesorregião Norte Central teve as maiores produções até o ano de 1999 (9.179,480ton), seguida da Norte Pioneiro até 1993 (3.522,940ton). Após o ano de 1993, a mesorregião Noroeste (4.144,598ton) ultrapassou a Norte Pioneiro (4.050,079ton) e a partir de 2001 ultrapassou também a Norte Central até o final do período, com valores em torno de quatro mil toneladas (Figura 26). Os números da produção, além de variarem por mesorregiões, variam também em razão do período.

Dentro do período analisado, observa-se uma queda na produção para as quatro principais mesorregiões no ano de 2000, em especial, seguido de 2005. De 1999 para 2000, houve redução da produção em torno de 1.600ton na mesorregião Noroeste, 1.300ton na mesorregião Norte Central, 744ton na Norte Pioneiro e 254ton na região Centro-Ocidental. No ano de 2005, em relação ao anterior, houve reduções apenas nas mesorregiões Norte Central e Norte Pioneiro, com valores aproximados de 1.800 e 1.080 toneladas, respectivamente.

De modo geral, o aumento no valor da produção nas mesorregiões acompanhou o aumento da área plantada (Figura 24 e 26). Entretanto, para os anos de 1991, 1999 e 2005, houve aumento da área plantada e redução na produção e na produtividade para a mesorregião Norte Central, e redução da área plantada e aumento da produção e da produtividade nos anos de 1999 e 2003 para a região Norte Pioneiro (Figura 24 e 26). 


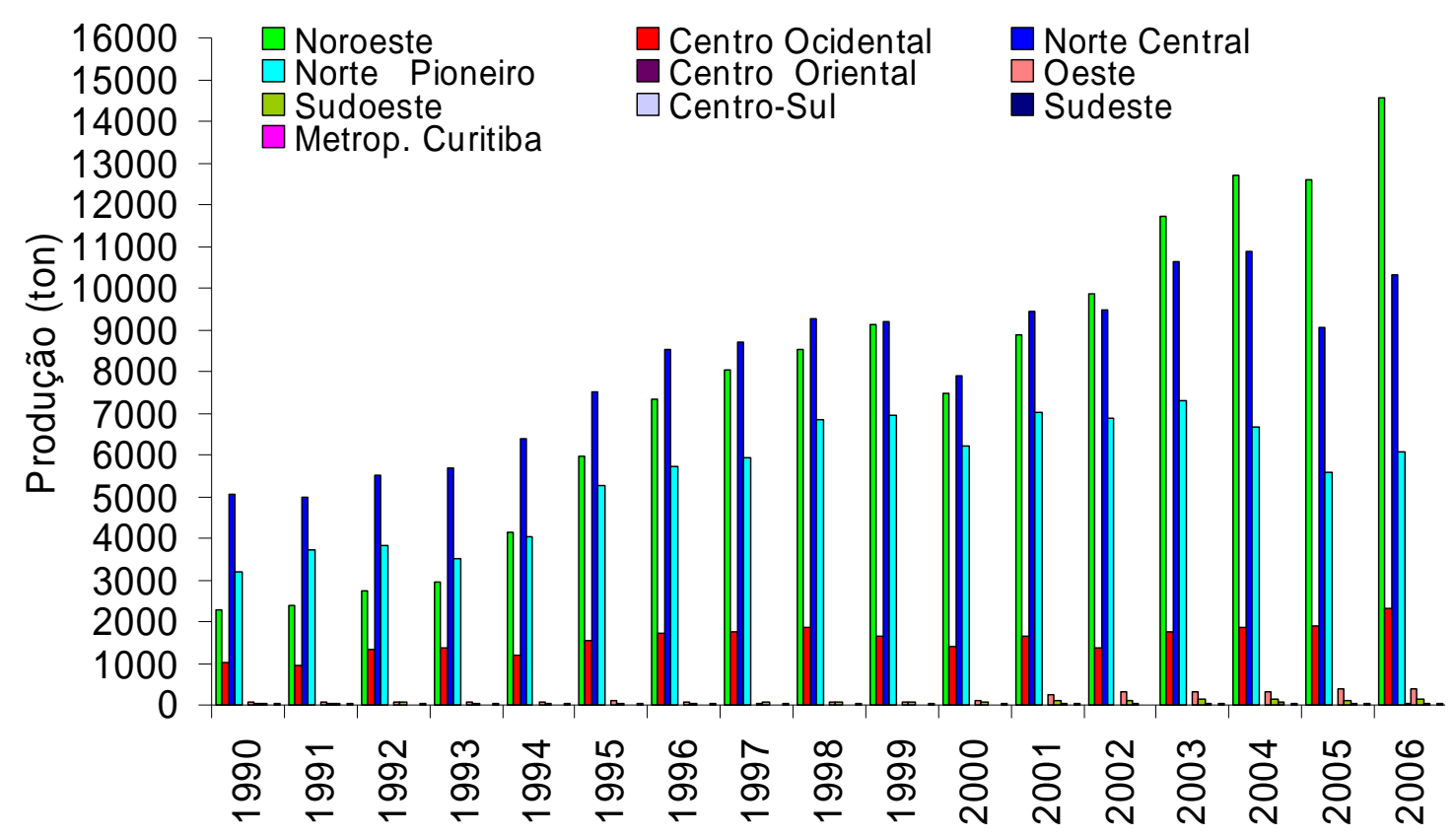

Figura 26 - Produção anual da cana para as mesorregiões paranaenses no período de 1990 a 2006. Org.: Domingues, I.A.S. (2008).

Para um melhor detalhamento, essas três variáveis (área plantada, produção e produtividade) foram analisadas em subescala dentro das mesorregiões, em nível de microrregiões e municípios, conforme o próximo item.

\subsection{2 - Análise da cultura da cana-de-açúcar por microrregiões e municípios}

As 10 mesorregiões paranaenses subdividem-se em 39 microrregiões, as quais perfazem um total de 399 municípios. Dessas 39 microrregiões, 18 compõem as 4 mesorregiões com melhor desempenho, produtividade média anual acima de 69 ton/ha (Tabela 3). Do total das 18 microrregiões, 3 delas (Paranavaí, Umuarama e Cianorte), que compõem a mesorregião Noroeste paranaense), estão localizadas em solos originados da rocha arenito $e$ as demais em solos originados predominantemente do basalto, salvo pequenas manchas ou cunhas do arenito nas áreas de transição. Essas 18 microrregiões totalizam 211 municípios, ou 52,88\% do 
total de municípios. Desse total, 42 municípios não cultivaram cana, resultando dessa forma em 169 municípios produtores (Tabela 10).

Tabela 10 - Relação das 18 microrregiões paranaenses e número de municípios produtores e não produtores de cana-de-açúcar no período de 1990 a 2006.

\begin{tabular}{|c|c|c|c|}
\hline Meso/microrregião & №. municípios & $\begin{array}{l}\text { №. municípios } \\
\text { não produtores }\end{array}$ & $\begin{array}{l}\text { № município } \\
\text { produtores }\end{array}$ \\
\hline \multicolumn{4}{|l|}{ Noroeste } \\
\hline 1-Paranavaí & 29 & 7 & 22 \\
\hline 2-Umuarama & 21 & 5 & 16 \\
\hline 3-Cianorte & 11 & 0 & 11 \\
\hline Sub-total & 61 & 12 & 49 \\
\hline \multicolumn{4}{|l|}{ Norte Central } \\
\hline 4-Astorga & 22 & 1 & 21 \\
\hline 5-Porecatu & 8 & 3 & 5 \\
\hline 6-Floraí & 7 & 1 & 6 \\
\hline 7-Maringá & 5 & 0 & 5 \\
\hline 8-Apucarana & 9 & 3 & 6 \\
\hline 9-Londrina & 6 & 2 & 4 \\
\hline 10-Faxinal & 7 & 4 & 3 \\
\hline 11-Ivaiporã & 15 & 5 & 10 \\
\hline Sub-total & 79 & 19 & 60 \\
\hline \multicolumn{4}{|l|}{ Norte Pioneiro } \\
\hline 12-Assaí & 8 & 2 & 6 \\
\hline 13-Cornélio Procópio & 14 & 2 & 12 \\
\hline 14-Jacarezinho & 6 & 0 & 6 \\
\hline 15-Ibaiti & 8 & 1 & 7 \\
\hline 16-Wenceslau Braz & 10 & 0 & 10 \\
\hline Sub-total & 46 & 5 & 41 \\
\hline \multicolumn{4}{|l|}{ Centro-Ocidental } \\
\hline 17-Goiorê & 11 & 6 & 5 \\
\hline 18-Campo Mourão & 14 & 0 & 14 \\
\hline Sub-total & 25 & 6 & 19 \\
\hline Total & 211 & 42 & 169 \\
\hline
\end{tabular}

Org.: Domingues, I.A.S. (2007).

Os números da cana-de-açúcar em termos de área plantada, produção e produtividade, por microrregião paranaense, mostram sua evolução tanto espacial quanto temporal (Tabelas 11 e 12).

Com relação à área plantada, observa-se, ao longo da série estudada, que as maiores variações aconteceram principalmente em áreas com mais tradição de cultivo, mesorregiões Norte Pioneiro e Norte Central. As microrregiões que apresentaram menores variações foram as 3 pertencentes à mesorregião Noroeste (Tabelas 11 e 12). 
A microrregião de Paranavaí, por exemplo, teve aumento em área plantada em todos os anos da série, chegando ao final do período com um aumento de 54.592ha, enquanto as outras duas microrregiões, Umuarama e Cianorte, tiveram redução nos anos de 1992, 1993 e 2001 e 1992 e 2000, embora o aumento no período fosse de 46.425 e de 57.845 respectivamente (Tabela 12).

O aumento médio por ano, nessas microrregiões, ficou em torno de 3.200ha a 3.600ha. Para as demais microrregiões, o aumento médio por ano ficou abaixo de 550ha, com exceção de Astorga e Jacarezinho, 2.650 e 1.385ha. Dentre todas essas microrregiões, apenas a micro de lbaiti teve, no período de 17 anos, redução em área plantada; em 1990 a área era de 7.129ha e em 2006 de 5.830, uma perda, portanto, de 1.299.

Com relação à produção, esta apresentou valores mais elevados nas microrregiões com área plantada, no período, acima de 24 mil hectares. Esses valores referem-se às microrregiões de Paranavaí, Umuarama, Cianorte, Astorga e Jacarezinho, com produção entre 1,8 a 3,8 milhões de toneladas (Tabela 12).

Conforme Zampieri (2006), a concentração da produção sucroalcooleira paranaense se distribui pelas microrregiões de Umuarama com 30\%, Maringá com $16 \%$, Jacarezinho e Paranavaí com $13 \%$ cada uma, Londrina com $11 \%$, Cornélio Procópio 5\%, Campo Mourão 4\%, e Apucarana e Ivaiporã com 3\% cada. Todas localizadas nas mesorregiões Norte Central e Pioneiro, Noroeste e Centro-Ocidental.

Em termos de produtividade média do período, as 18 microrregiões apresentaram valores entre 68 ton/ha e 94 ton/ha. (Tabela 12). As microrregiões de Ivaiporã, Londrina, Maringá (Norte Central) e Jacarezinho (Norte Pioneiro), tiveram as maiores produtividades, acima de 85 ton/ha. Entre essas, Londrina teve a maior produtividade, com 94,1 ton/ha. Para as microrregiões do Noroeste paranaense (Paranavaí, Umuarama e Cianorte), os valores foram em torno de 74 ton/ha a 80 ton/ha. Dentre essas 3, a microrregião de Paranavaí se destacou, com 80 ton/ha. 
Tabela 11 - Área plantada (ha), produção (ton) e produtividade (ton/ha) da cultura de cana-de-açúcar para as 18 microrregiões paranaense pertencentes às mesorregiões Noroeste, Norte (Central e Pioneiro) e Centro-Ocidental, período de 1990 a 2006.

\begin{tabular}{|c|c|c|c|c|c|c|c|c|c|c|c|c|c|c|c|c|c|}
\hline Microrr & 1990 & 1991 & 1992 & 1993 & 1994 & 1995 & 1996 & 1997 & 1998 & 1999 & 2000 & 2001 & 2002 & 2003 & 2004 & 2005 & 2006 \\
\hline Pvai/ ha & 10.266 & 10.842 & 12.579 & 16.660 & 20.185 & 22.466 & 27.489 & 31.561 & 33.880 & 36.536 & 37.795 & 39.698 & 44.315 & 49.408 & 53.519 & 56.792 & 64.858 \\
\hline ton & 747.644 & 741.064 & 927.189 & 153.841 & 1.692 .684 & 1.861 .291 & 2.403 .635 & 3.057 .906 & 3.060 .699 & 3.124 .847 & 2.513 .275 & 3.097 .793 & 3.604 .235 & 4.219 .952 & 4.294 .81 & 3.939 .33 & 5.108 .845 \\
\hline ton/ha & 72.827 & 68.351 & 73.814 & 69.258 & 83.858 & 83.653 & 87.439 & 96.888 & 90.339 & 85.527 & 66.497 & 78.033 & 81.332 & 85.410 & 80.248 & 69.364 & 78.769 \\
\hline $\begin{array}{l}\text { Umuara } \\
\text { ma ha }\end{array}$ & 5.976 & 6.513 & 6.262 & 4.163 & 5.044 & 17.459 & 22.104 & 23.181 & 24.186 & 28.272 & 29.260 & 27.042 & 33.025 & 37.263 & 41.207 & 48.933 & 52.401 \\
\hline ton & 468.794 & 368.901 & 382.107 & 246.842 & 286.700 & 1.436 .565 & 1.809 .230 & 1.780 .242 & 1.965 .154 & 2.151 .490 & 1.786 .203 & 1.989 .367 & 2.298 .874 & 2.763 .842 & $\begin{array}{r}3.330 .80 \\
7 \\
\end{array}$ & $\begin{array}{r}3.658 .68 \\
9 \\
\end{array}$ & 3.859.284 \\
\hline ton/ha & 78.446 & 56.640 & 61.019 & 59.294 & 56.839 & 82.282 & 81.850 & 76.797 & 81.251 & 76.099 & 61.045 & 73.565 & 69.610 & 74.171 & 80.831 & 74.769 & 73.649 \\
\hline $\begin{array}{l}\text { Cianort } \\
\text { ha }\end{array}$ & 14.964 & 18.399 & 20.310 & 23.213 & 28.714 & 34.509 & 35.059 & 39.932 & 39.881 & 50.709 & 44.661 & 48.691 & 53.399 & 57.333 & 61.930 & 67.486 & 72.809 \\
\hline ton & 1.081 .558 & 1.265 .472 & 1.440 .801 & 1.557 .399 & 2.165 .214 & 2.650 .604 & 3.116 .352 & 3.192 .681 & 3.489 .679 & 3.843 .131 & 3.176 .682 & 3.803 .672 & 3.950 .698 & 4.720 .509 & $\begin{array}{r}5.067 .87 \\
5 \\
\end{array}$ & $\begin{array}{r}5.001 .00 \\
1 \\
\end{array}$ & 5.580 .177 \\
\hline ton/ha & 72.277 & 68.779 & 70.940 & 67.091 & 75.406 & 76.809 & 88.888 & 79.952 & 87.502 & 75.787 & 71.128 & 78.118 & 73.984 & 82.334 & 81.832 & 74.104 & 76.641 \\
\hline $\begin{array}{l}\text { Astorga } \\
\text { ha }\end{array}$ & 27.118 & 31.037 & 30.740 & 33.268 & 36.202 & 39.026 & 46.602 & 46.803 & 45.821 & 53.572 & 52.729 & 54.517 & 60.620 & 60.398 & 69.028 & 63.621 & 69.513 \\
\hline ton & 2.129 .008 & 2.200 .597 & 2.166 .234 & 2.340 .445 & 2.687 .618 & 3.123 .856 & 3.935 .169 & 3.883 .765 & 4.119.319 & 4.324 .885 & 3.693 .648 & 4.334 .617 & 4.853.997 & 5.233 .785 & $\begin{array}{r}5.370 .64 \\
9 \\
\end{array}$ & $\begin{array}{r}4.504 .51 \\
3 \\
\end{array}$ & 5.221 .767 \\
\hline ton/ha & 78.509 & 70.902 & 70.469 & 70.351 & 74.239 & 80.045 & 84.442 & 82.981 & 89.900 & 80.730 & 70.049 & 79.509 & 80.072 & 86.654 & 77.803 & 77.803 & 75.119 \\
\hline $\begin{array}{l}\text { Porec } \\
\text { ha }\end{array}$ & 17.443 & 18.660 & 18.428 & 18.515 & 19.012 & 18.908 & 22.628 & 21.985 & 22.813 & 22.944 & 22.109 & 22.934 & 19.899 & 20.794 & 23.913 & 20.958 & 20.833 \\
\hline ton & 1.232 .750 & 930.126 & 1.226 .637 & 1.187 .929 & 1.286 .979 & 1.481 .534 & 1.628.481 & 1.673 .632 & 1.732 .998 & 1.606 .490 & 1.509 .295 & 1.858 .482 & 1.444 .741 & 1.777 .150 & $\begin{array}{r}1.769 .64 \\
9 \\
\end{array}$ & $\begin{array}{r}1.281 .65 \\
3 \\
\end{array}$ & 1.220 .948 \\
\hline ton/ha & 70.673 & 49.845 & 66.563 & 64.160 & 67.692 & 78.354 & 71.967 & 76.126 & 75.965 & 70.017 & 68.266 & 81.036 & 72.603 & 85.464 & 74.003 & 61.153 & 58.606 \\
\hline $\begin{array}{l}\text { Floraí } \\
\text { ha }\end{array}$ & 1.412 & 2.242 & 2.139 & 3.988 & 4.088 & 4.550 & 4.373 & 5.322 & 4.854 & 4.624 & 2.843 & 3.145 & 3.504 & 4.133 & 4.540 & 4.605 & 5.280 \\
\hline ton & 104.671 & 149.887 & 144.856 & 307.948 & 343.877 & 432.811 & 383.414 & 450.088 & 400.509 & 357.259 & 200.911 & 273.108 & 302.835 & 404.534 & 405.240 & 427.727 & 483.700 \\
\hline ton/ha & 74.129 & 66.854 & 67.721 & 77.218 & 84.118 & 95.123 & 87.677 & 84.571 & 82.511 & 77.261 & 70.668 & 86.838 & 86.425 & 97.879 & 89.259 & 92.883 & 91.609 \\
\hline $\begin{array}{l}\text { Maringá } \\
\text { ha }\end{array}$ & 6.395 & 6.209 & 6.096 & 5.811 & 7.324 & 6.536 & 8.510 & 8.475 & 8.907 & 9.161 & 8.359 & 7.843 & 7.833 & 7.207 & 8.364 & 8.364 & 8.500 \\
\hline ton & 480.131 & 429.751 & 471.301 & 427.953 & 554.240 & 584.660 & 876.030 & 810.897 & 853.485 & 785.458 & 647.219 & 712.694 & 692.541 & 702.255 & 805.371 & 802.659 & 784.400 \\
\hline ton/ha & 75.079 & 69.214 & 77.313 & 73.645 & 75.674 & 89.452 & 102.941 & 95.681 & 95.821 & 85.739 & 77.427 & 90.870 & 88.413 & 97.440 & 96.290 & 95.965 & 92.282 \\
\hline $\begin{array}{l}\text { Apucar } \\
\text { ana }\end{array}$ & 1.315 & 1.384 & 1.357 & 1.547 & 1.959 & 1.984 & 2.515 & 2.313 & 2.854 & 3.160 & 2.670 & 2.538 & 2.510 & 2.964 & 2.834 & 2.619 & 3.373 \\
\hline ton & 93.075 & 102.651 & 106.427 & 108.630 & 140.905 & 181.444 & 215.188 & 213.743 & 280.338 & 272.738 & 169.262 & 216.530 & 201.311 & 253.058 & 244.997 & 210.308 & 318.133 \\
\hline ton/ha & 70.779 & 74.169 & 78.428 & 70.219 & 71.927 & 91.453 & 85.561 & 92.409 & 98.226 & 86.309 & 63.394 & 85.315 & 80.203 & 85.377 & 86.449 & 80.300 & 94.317 \\
\hline
\end{tabular}


continuação

\begin{tabular}{|c|c|c|c|c|c|c|c|c|c|c|c|c|c|c|c|c|c|}
\hline $\begin{array}{l}\text { Londrin } \\
\text { ha }\end{array}$ & 3.266 & 3.645 & 4.012 & 4.665 & 4.982 & 4.574 & 5.067 & 4.478 & 3.974 & 4.153 & 4.341 & 4.670 & 5.138 & 5.100 & 5.642 & 4.903 & 5.539 \\
\hline ton & 260.597 & 318.792 & 404.794 & 403.497 & 400.650 & 425.003 & 492.149 & 415.825 & 427.640 & 419.244 & 402.981 & 479.979 & 504.107 & 515.071 & 572.755 & 397.497 & 516.022 \\
\hline ton/ha & 79.790 & 87.460 & 100.895 & 86.494 & 80.419 & 92.917 & 97.128 & 92.859 & 107.609 & 100.949 & 92.831 & 102.779 & 98.113 & 100.994 & 101.516 & 81.072 & 93.161 \\
\hline $\begin{array}{l}\text { Faxinal } \\
\text { ha }\end{array}$ & 4.113 & 4.951 & 5.353 & 6.231 & 6.273 & 6.440 & 6.576 & 6.422 & 7.890 & 8.310 & 7.607 & 8.195 & 7.930 & 8.285 & 9.273 & 8.318 & 9.561 \\
\hline ton & 304.202 & 406.369 & 426.430 & 377.730 & 420.240 & 544.492 & 578.858 & 586.094 & 747.948 & 709.206 & 491.776 & 728.788 & 590.767 & 719.586 & 837.853 & 657.028 & 875.880 \\
\hline ton/ha & 73.961 & 82.078 & 79.661 & 60.621 & 66.991 & 84.548 & 88.025 & 91.263 & 94.796 & 85.343 & 64.647 & 88.930 & 74.497 & 86.854 & 90.354 & 78.988 & 91.609 \\
\hline Ivaip/ha & 5.615 & 4.800 & 5.742 & 5.642 & 7.103 & 8.950 & 5.359 & 8.610 & 8.870 & 8.930 & 10.113 & 9.718 & 10.466 & 5.615 & 4.800 & 5.742 & 5.642 \\
\hline ton & 463.306 & 452.126 & 552.805 & 515.010 & 555.977 & 737.750 & 430.794 & 680.200 & 699.700 & 704.200 & 786.581 & 851.342 & 899.269 & 1.035 .456 & 877.244 & 761.609 & 898.715 \\
\hline ton/ha & 82.512 & 94.192 & 96.273 & 91.281 & 78.273 & 82.430 & 80.387 & 79.001 & 78.883 & 78.857 & 77.779 & 87.604 & 85.922 & 96.501 & 92.458 & 80.474 & 87.177 \\
\hline $\begin{array}{l}\text { Assaí/h } \\
\text { a }\end{array}$ & 1.060 & 1.340 & 1.340 & 1.340 & 1.340 & 1.850 & 2.150 & 2.150 & 2.470 & 2.530 & 2.530 & 2.180 & 2.180 & 2.300 & 2.405 & 1.900 & 1.760 \\
\hline ton & 78.440 & 107.200 & 116.655 & 100.500 & 85.425 & 148.000 & 172.000 & 172.000 & 196.450 & 200.500 & 200.500 & 174.250 & 174.250 & 215.225 & 224.675 & 167.250 & 155.243 \\
\hline ton/ha & 74.000 & 80.000 & 87.055 & 75.000 & 63.750 & 80.000 & 80.000 & 80.000 & 79.534 & 79.249 & 79.249 & 79.931 & 79.931 & 93.576 & 93.419 & 88.026 & 88.206 \\
\hline $\begin{array}{l}\text { C.Proc/ } \\
\text { ha }\end{array}$ & 14.512 & 14.598 & 15.790 & 15.785 & 19.432 & 26.920 & 32.350 & 32.350 & 39.030 & 36.150 & 36.150 & 35.820 & 34.820 & 34.660 & 30.280 & 20.930 & 19.700 \\
\hline ton & 1.041 .890 & 1.239 .865 & 1.260 .047 & 1.285 .270 & 1.552 .384 & 2.194 .100 & 2.624 .000 & 2.624 .000 & 3.131 .650 & 2.923 .750 & 2.923 .750 & .995 .850 & 2.785 .100 & 2.982 .820 & 2.676 .650 & 1.698 .750 & 1.616 .300 \\
\hline ton/ha & 71.795 & 84.933 & 79.800 & 81.423 & 79.888 & 81.504 & 81.112 & 81.112 & 80.236 & 80.878 & 80.878 & 83.636 & 79.985 & 86.059 & 88.396 & 81.163 & 82.045 \\
\hline Ibaití/ha & 7.129 & 7.405 & 7.425 & 8.309 & 8.307 & 8.652 & 5.240 & 5.683 & 6.240 & 7.815 & 7.815 & 7.060 & 7.060 & 5.890 & 5.590 & 4.810 & 5.830 \\
\hline ton & 404.095 & 523.150 & 516.950 & 541.430 & 541.270 & 569.270 & 333.400 & 356.246 & 483.150 & 627.806 & 433.170 & 511.325 & 488.650 & 399.840 & 384.380 & 342.080 & 406.500 \\
\hline ton/ha & 56.683 & 70.648 & 69.622 & 161 & 65.158 & 65.796 & 63.625 & 62.686 & 77.427 & 80.333 & 428 & 72.425 & 9.213 & 7.884 & 68.762 & 1.118 & 69.725 \\
\hline $\begin{array}{l}\text { Jacarez } \\
\text { ha }\end{array}$ & 20.914 & 22.700 & 26.800 & 19.730 & 25.407 & 29.200 & 32.350 & 34.673 & 31.375 & 32.311 & 30.955 & 33.120 & 36.700 & 36.683 & 38.503 & 42.473 & 43.073 \\
\hline ton & 1.636 .920 & 1.816 .000 & 1.887 .000 & 1.543 .340 & 1.809 .000 & 2.298 .000 & 2.524 .600 & 2.706 .440 & 2.946 .800 & 3.123 .784 & 2.600 .016 & 3.283 .250 & 3.373 .510 & \begin{tabular}{|l}
3.664 .340 \\
\end{tabular} & 3.334 .940 & 3.328 .996 & 3.840 .740 \\
\hline ton/ha & 78.269 & 80.000 & 70.410 & 78.223 & 71.287 & 78.698 & 78.040 & 78.056 & 93.921 & 96.678 & 83.993 & 99.131 & 91.921 & 99.892 & 86.615 & 78.379 & 89.168 \\
\hline W.B/ha & 608 & 640 & 645 & 742 & 835 & 612 & 992 & 905 & 1.092 & 1.121 & 1.143 & 791 & 799 & 776 & 853 & 845 & 850 \\
\hline ton & 44.488 & 44.840 & 41.150 & 52.400 & 62.000 & 48.460 & 67.992 & 65.620 & 74.560 & 82.180 & 56.212 & 57.789 & 56.350 & 49.300 & 51.550 & 56.750 & 57.100 \\
\hline ton/ha & 73.533 & 70.062 & 63.798 & 70.619 & 74.251 & 79.183 & 68.540 & 72.508 & 68.278 & 73.309 & 49.179 & 73.058 & 70.525 & 63.530 & 60.433 & 67.159 & 67.176 \\
\hline $\begin{array}{l}\text { Goioerê } \\
\text { ha }\end{array}$ & 5.274 & 5.394 & 7.546 & 5.657 & 4.087 & 5.220 & 6.753 & 6.732 & 7.089 & 7.418 & 6.232 & 6.745 & 7.002 & 6.360 & 7.133 & 7.343 & 8.033 \\
\hline ton & 337.240 & 313.262 & 524.940 & 392.710 & 252.254 & 354.960 & 498.529 & 459.827 & 536.192 & 417.903 & 295.386 & 442.760 & 455.319 & 577.668 & 653.660 & 579.565 & 758.280 \\
\hline ton/ha & 63.943 & 58.076 & 70.151 & 69.420 & 61.721 & 68.000 & 73.823 & 68.304 & 75.637 & 56.336 & 47.398 & 65.642 & 65.026 & 90.828 & 91.638 & 78.927 & 94.395 \\
\hline C.M/ha & 8.514 & 7.869 & 9.558 & 10.902 & 12.051 & 14.205 & 15.364 & 15.123 & 15.399 & 16.141 & 14.938 & 14.290 & 11.487 & 12.114 & 13.527 & 17.106 & 17.296 \\
\hline ton & 668.712 & 647.230 & 812.953 & 976.934 & 954.168 & 1.195 .568 & 1.223 .495 & 1.285 .754 & 1.327 .567 & 1.241 .486 & 1.110 .451 & 1.194 .868 & 918.669 & 1.159 .524 & 1.207.743 & 1.304 .138 & 1.567 .632 \\
\hline ton/ha & 78.542 & 82.250 & 85.054 & 89.610 & 79.177 & 84.165 & 79.633 & 85.019 & 86.211 & 76.915 & 74.337 & 83.615 & 79.974 & 95.717 & 89.283 & 76.238 & 90.635 \\
\hline
\end{tabular}


A variação entre produção e produtividade, de modo geral, se deu para a maioria das microrregiões no ano de 2000. Os casos que mais se destacaram foram os das microrregiões de Paranavaí, Umuarama, Londrina e Wenceslau Braz, com aumento em área plantada e redução nos valores de produção e produtividade. Para o período de 1990 a 1994, foi comum, para muitas dessas microrregiões, uma redução acima de 10 ton/ha no valor da produtividade. Para as microrregiões de Assaí, Faxinal, Londrina, Paranavaí, Porecatu e Umuarama, as reduções ficaram entre 21 e 23 ton/ha (Tabela 11).

Tabela 12 - Valores médios de área plantada, produção e produtividade da cana-de-açúcar para 18 microrregiões paranaenses, período 1990 a 2006.

\begin{tabular}{|c|c|c|c|}
\hline Microrregião & $\begin{array}{l}\text { Área Plantada } \\
\text { (ha) }\end{array}$ & Produção (ton) & $\begin{array}{l}\text { Produtividade média } \\
\text { (ton/ha) }\end{array}$ \\
\hline 1-Paranavaí & $33.461,71$ & $2.679 .355,7$ & 80,07 \\
\hline 2-Umuarama & $24.252,41$ & $1.799 .005,4$ & 74,17 \\
\hline 3-Cianorte & $41.882,29$ & $3.241 .382,6$ & 77,39 \\
\hline 4-Astorga & $48.271,47$ & $3.771 .992,5$ & 78,14 \\
\hline 5-Porecatu & $20.751,53$ & $1.461 .733,8$ & 70,43 \\
\hline 6-Floraí & $3.861,29$ & $327.845,59$ & 84,90 \\
\hline 7-Maringá & $7.640,82$ & $671.826,18$ & 87,92 \\
\hline 8-Apucarana & $2.346,82$ & $195.808,12$ & 83,43 \\
\hline 9-Londrina & $4.597,00$ & $432.741,35$ & 94,13 \\
\hline 10-Faxinal & $71.60,47$ & $588.426,29$ & 82,17 \\
\hline 11-Ivaiporã & $8.229,94$ & $700.122,59$ & 85,07 \\
\hline 12-Assaí & $1.930,88$ & $158.150,76$ & 81,90 \\
\hline 13-Cornélio Procópio & $27.016,29$ & $220.9186,8$ & 81,77 \\
\hline 14-Jacarezinho & $31.586,29$ & $2.689 .275,1$ & 85,14 \\
\hline 15-lbaití & $6.838,82$ & $462.512,47$ & 67,63 \\
\hline 16-Wenceslau Braz & 838,17 & $56.984,765$ & 67,98 \\
\hline 17-Goioerê & $6.471,64$ & $461.791,47$ & 71,35 \\
\hline 18-Campo Mourão & $13.287,29$ & $1.105 .699,5$ & 83,21 \\
\hline Total/média & $290.425,18$ & 23.013 .841 & 79,24 \\
\hline
\end{tabular}

Org.: Domingues, I.A.S. (2007).

Em solos areníticos, a microrregião que apresentou maior produtividade foi a de Paranavaí, e em solos basálticos a microrregião de Londrina (Tabela 13). Em nível mais detalhado, ou seja, por municípios, os dados de área plantada, quantidade produzida e rendimento mostraram situações diferenciadas em termos quantitativos e qualitativos, conforme o item a seguir. 


\subsection{3 - Análise da cultura da cana-de-açúcar por municípios}

Dentre os 169 municípios, 17, em área de solos predominantemente originados em rochas basálticas ou em área de transição para o arenito, tiveram rendimentos médios acima de 85 ton/ha. Em solos areníticos apenas um município teve rendimento de 82 ton/ha, (Tabela 13 e 14).

Dentre esses 17 municípios, 11 fazem parte da mesorregião Norte Central Paranaense, 2 da Noroeste Paranaense, 2 da Norte Pioneiro Paranaense e 2 da mesorregião Centro-Ocidental Paranaense. Desses, 8 apresentaram valores médios da produtividade média acima de 90 ton/ha. Apenas um dos 2 municípios localizados na microrregião de solos do arenito teve rendimento de 91,4 ton/ha. Em solos de basalto , 3 municípios alcançaram produtividade acima de 94 ton/ha (Tabela 14).

O valor médio de área plantada com cana-de-açúcar desses municípios foi de 57.013ha. Esse valor representa algo em torno de 19\% da área plantada com canade-açúcar no estado do Paraná.

Com referência à redução de área plantada, os anos com maior redução foram os de 2000, com 58,8\% dos municípios; de 1998, com 47\%; de 1996, 1997 e 2005, com 35\%; de 1995, 2001 e 2004 com 30\%, e os demais abaixo de $23,5 \%$. O ano de 2006 teve perda de área em apenas um município, o de Engenheiro Beltrão (Tabela 13). Para alguns municípios, a perda se deu de forma consecutiva, como foi o caso de Itambé e Marialva, que tiveram cinco e sete anos de perda, dos quais quatro (1998-2001) e cinco (1999-2003) foram sequenciais, respectivamente. A maioria dos municípios teve entre quatro e sete anos com redução de área plantada. Com isso, percebe-se que as maiores variações ocorreram principalmente nos anos de 1998 e 2000.

Referente à produção da cana, os anos de 2000 e 2005 foram os que tiveram maior número de municípios com redução de safras, 11 e 13 municípios. Em 2000 as perdas no valor da quantidade produzida ficaram entre 2,6\% (município de Rolândia) e 31,5\% (município de Mandaguari) e em 2005 as perdas variaram em torno 4\% (São Tomé) a 38\% (Cambé). A maioria dos demais anos teve de 5 a 8 municípios. Para estes, as maiores reduções ocorreram nos anos de 2001 em Itaguajé, com 98\% de redução; 2000 em Pitangueiras, com 61\%; 2002 em Cambé, 
com 49\%, e nos demais anos as reduções foram de 16\% a 46\%. Analisando essas reduções por municípios, houve alguns com três (Cambé e Fênix) a oito (Mandaguari) anos com redução (Tabela 13).

Em termos de aumento anual na produção, percebeu-se que o número de municípios por ano com valores acima de 50 mil toneladas foi maior em 1994 e 2006, com 7 e 8 municípios respectivamente. Em 1992 e 1995 foram 5 municípios, 2001 com 6 e os demais anos abaixo desse valor. Em nenhum dos municípios foi registrado esse aumento no ano de 2005.

Em relação aos valores de produtividade, de um ano agrícola para outro, observou-se que os anos de 1994, 1998, 1999, 2000, 2002, 2004 e 2005 foram os que apresentaram maior número de municípios com redução na produtividade, de 7 a 15 municípios. No ano de 2005, 88\% dos municípios tiveram redução na produtividade (de 5,0 ton/ha a 30,0 ton/ha). Em 2000, 2002, 2004 o percentual foi em torno de $70 \%$ dos municípios (redução de até 56 ton/ha). Para os anos de 1994, 1998 e 1999 o percentual de municípios esteve entre 41\% a 53\%. O ano com menor número de municípios com redução foi o de 2001, com apenas 2 municípios, Cambé e Novo Itacolomi. Os demais anos do período tiveram entre 4 e 6 municípios com redução de produtividade. Quanto aos aumentos nos valores da produtividade média, considerando aqueles acima de 10 ton/ha, destacaram-se os seguintes anos: 2001 teve aumento na produtividade em 9 municípios, e esse aumento variou de 10,7 ton/ha a 25,7 ton/ha; o ano de 1995 teve 8 municípios com aumento de produtividade média entre 11,1 ton/ha e 19,8 ton/ha; o ano de 1998 teve 7 municípios e aumento na produtividade entre 10,2 ton/ha e 24,1 ton/ha. Os anos de 1992, 1996 e 2003 tiveram número de municípios de 4 a 6 e estes com aumento não superior a 24 ton/ha. Os demais anos tiveram número de municípios até 2 e aumento de até 51,7 ton/ha. 
Tabela 13 - Valores médios da produtividade, área plantada e produção da cana-de-açúcar para os municípios com rendimento em torno de 85,0 ton/ha, 1990 a 2006. Localização em ordem de mesorregião, microrregião e município.

\begin{tabular}{|c|c|c|c|c|c|c|c|c|c|c|c|c|c|c|c|c|c|}
\hline Produt (ton/ha) & 1990 & 1991 & 1992 & 1993 & 1994 & 1995 & 1996 & 1997 & 1998 & 1999 & 2000 & 2001 & 2002 & 2003 & 2004 & 2005 & 2006 \\
\hline NO-Cianorte/Jussara & 81,7 & 69,7 & 90,6 & 87,2 & 90,7 & 94,4 & 98,8 & 92,2 & 108,0 & 108,1 & 83,5 & 90,6 & 93,1 & 86,6 & 103,2 & 82,6 & 89,6 \\
\hline NO-Pvai/Mirador & 70.3 & 70.0 & 80.2 & 80.0 & 84.0 & 100.0 & 88.8 & $\mathrm{~S} / \mathrm{D}$ & 91. & 82.0 & 59.5 & 74.0 & 82.0 & 71.4 & 86.6 & 84.7 & 88.2 \\
\hline NO-Cianorte/S.Tomé & 83,1 & 72,7 & 83,9 & 86,2 & 98,5 & 89,9 & 98,3 & 85,8 & 93,0 & 86,6 & 72,4 & 83,2 & 78,0 & 82,8 & 90,6 & 83,8 & 80,4 \\
\hline NC-Astorga/Itaguajé & 105.0 & 74.3 & 79.5 & 66.9 & 71.4 & S/D & 161.5 & 101.1 & 86.3 & 68.4 & 80.0 & 72.6 & 111.2 & 93.6 & 79.0 & 112.0 & $S / D$ \\
\hline NC-Astorga/Lobato & 84,0 & 88,0 & 90,7 & 95,7 & 91,3 & 94,2 & 86,5 & 90,1 & 109,9 & 99,9 & 76,1 & 84,4 & 77,3 & 86,6 & 83,0 & 70,5 & 77,2 \\
\hline NC-Floraí/ltambé & 98,0 & 115,9 & 86,0 & 86,0 & 92,0 & 106,9 & 90,1 & 88,5 & 77,6 & 65,5 & 67,6 & 89,9 & 96,9 & 112,1 & 97,4 & 92,0 & 90,0 \\
\hline NC-Mgá/Mandaguarí & 81,0 & 85,1 & 107,0 & 73,5 & 69,6 & 77,7 & 96,0 & 86,7 & 110,9 & 77,0 & 64,8 & 79,5 & 90,2 & 113,2 & 102,7 & 95,0 & 90,0 \\
\hline NC-Mga/Marialva & 90,0 & 86,6 & 99,7 & 88,4 & 82,0 & 101,8 & 112,0 & 104,5 & 98,6 & 85,1 & 79,2 & 94,9 & 93,7 & 95,5 & 92,3 & 95,0 & 92,0 \\
\hline NC-Apuc/N.Itacolomi & S/D & $\mathrm{S} / \mathrm{D}$ & $\mathrm{S} / \mathrm{D}$ & $\mathrm{S} / \mathrm{D}$ & S/D & $S / D$ & $S / D$ & $\mathrm{~S} / \mathrm{D}$ & $S / D$ & 129,0 & 124,0 & 121,7 & 90,5 & 87,8 & 66,3 & 0 & 95,7 \\
\hline NC-Ldna/Cambé & 74,0 & 87,0 & 103,9 & 90,0 & 82,5 & 98,4 & 111,6 & 87,5 & 97,8 & 100,0 & 90,3 & 103,2 & 88,0 & 116,2 & 102,8 & 72,7 & 89,6 \\
\hline NC-Ldna/Pitangueiras & S/D & S/D & S/D & 85,5 & 80,7 & 78,8 & 84,1 & 100,0 & 95,2 & 91,5 & 35,3 & 103,2 & 90,6 & 108,6 & 104,8 & 70,2 & 76,1 \\
\hline NC-Ldna/Rolândia & 80,5 & 87,4 & 101,4 & 86,7 & 80,5 & 93,5 & 96,7 & 93,7 & 109,4 & 101,4 & 95,3 & 103,2 & 99,5 & 99,4 & 101,3 & 83,1 & $\overline{95,4}$ \\
\hline NC Ivaip/ S.J. Ivaí & 80,0 & 92,5 & 100,0 & 90,0 & 86,9 & 80,0 & 84,0 & 80,0 & 74,1 & 80,0 & 79,7 & 80,1 & 88,0 & 103,0 & 95,0 & 85,0 & 85,0 \\
\hline NC-Ivaip./S.P Ivaí & 85,0 & 98,5 & 98,0 & 94,2 & 79,4 & 85,0 & 84,0 & 80,0 & 80,0 & 80,0 & 79,5 & 91,3 & 88,0 & 98,4 & 94,7 & 80,6 & 88,8 \\
\hline NC-C.Proc./Sta Mariana & 74,0 & 87,0 & 80,0 & 85,0 & 85,0 & 90,0 & 90,0 & 90,0 & 85,0 & 85,0 & 85,0 & 90,0 & 85,0 & 90,0 & 95,0 & 90,0 & 85,0 \\
\hline $\begin{array}{l}\text { NP-Jacarezinho } \\
\text { Cambará }\end{array}$ & 78,0 & 80,0 & 70,0 & 78,0 & 71,9 & 90,0 & 78,0 & 78,0 & 94,0 & 94,0 & 84,6 & 100,0 & 92,0 & 100,0 & 88,0 & 80,0 & 90,0 \\
\hline COc-C.Mrão/E.Beltrão & 90,0 & 98,0 & 98,0 & 105,7 & 92,0 & 93,0 & 78,1 & 92,5 & 97,0 & 74,3 & 76,9 & 88,0 & 78,1 & 100,0 & 92,1 & 78,0 & 92,0 \\
\hline COc-C.Mrão/Fênix & 100,0 & 100,0 & & 90,0 & 70,0 & 85 & 106,7 & 97,9 & 86,8 & 90,9 & 102,8 & 102,8 & 98,0 & 98,0 & 98,0 & 77,0 & 90,0 \\
\hline
\end{tabular}


continuação

\begin{tabular}{|c|c|c|c|c|c|c|c|c|c|c|c|c|c|c|c|c|c|}
\hline Área plantada (ha) & 1990 & 1991 & 1992 & 1993 & 1994 & 1995 & 1996 & 1997 & 1998 & 1999 & 2000 & 2001 & 2002 & 2003 & 2004 & 2005 & 2006 \\
\hline NO-Cianorte/Jussara & 2.517 & 2.236 & 2.304 & 2.525 & 2.577 & 2.900 & 2.632 & 2.841 & 2.667 & 2786 & 2860 & 2.634 & 2.727 & 2.786 & 2.788 & 3.149 & 3.350 \\
\hline NO-Pvai/Mirador & 212 & 333 & 375 & 663 & 458 & 705 & 595 & $\mathrm{~S} / \mathrm{D}$ & 1.550 & 1.035 & 986 & 1.051 & 1.696 & 1.635 & 1.581 & 1.614 & 2.433 \\
\hline NO-Cianorte/S. Tomé & 3.264 & 3.956 & 4.447 & 4.272 & 5.009 & 5.405 & 6.913 & 7.296 & 6.683 & 7.605 & 7.530 & 7.813 & 7.474 & 8.906 & 8.769 & 9.055 & 9.311 \\
\hline NC-Astorga/Itaguajé & 9 & 120 & 118 & 118 & 258 & $S / D$ & 140 & 140 & 158 & 158 & 329 & 30 & 141 & 141 & 123 & 423 & $S / D$ \\
\hline NC-Astorga/Lobato & 2.560 & 3.569 & 3.399 & 3.487 & 4.579 & 4.097 & 4.926 & 4.065 & 4.526 & 6.800 & 6.748 & 6.947 & 8.071 & 6.150 & 7.429 & 7.304 & 7.347 \\
\hline NC-Floraí/ltambé & 300 & 554 & 654 & 2.438 & 2.517 & 2.796 & 2.263 & 2.374 & 2.141 & 1.777 & 1.367 & 1.302 & 1.378 & 1.661 & 4.700 & 2.007 & 2.010 \\
\hline NC-Mgá/Mandaguarí & 431 & 436 & 331 & 358 & 160 & 430 & 412 & 247 & 265 & 367 & 298 & 382 & 465 & 429 & 1.160 & 1.160 & 1.160 \\
\hline NC-Mga/Marialva & 2.099 & 2.237 & 2.140 & 2.378 & 3.253 & 1.628 & 4.125 & 4.448 & 4.574 & 4.571 & 3.633 & 3.466 & 2.927 & 2.788 & 3.165 & 3.165 & 3.200 \\
\hline NC-Apuc/N.Itacolomi & $S / D$ & S/D & $\mathrm{S} / \mathrm{D}$ & S/D & $\mathrm{S} / \mathrm{D}$ & $S / D$ & S/D & S/D & S/D & 9.675 & 8.804 & 8.889 & 6.335 & 6.415 & 4.844 & & 11.964 \\
\hline $\begin{array}{l}\text { NC-Londrina/ } \\
\text { Cambé }\end{array}$ & 132 & 135 & 177 & 263 & 298 & 285 & 334 & 450 & 352 & 383 & 438 & 550 & 326 & 383 & 475 & 413 & 600 \\
\hline NC-Ldna-Pitangueiras & $S / D$ & S/D & $\mathrm{S} / \mathrm{D}$ & 172 & 181 & 188 & 87 & 193 & 219 & 145 & 146 & 180 & 208 & 295 & 399 & 392 & 424 \\
\hline $\begin{array}{l}\text { NC-Ldna } \\
\text { /Rolândia }\end{array}$ & 3.098 & 3.510 & 3.789 & 4.190 & 4.463 & 4.061 & 4.606 & 3.795 & 3.403 & 3.625 & 3.757 & 3.900 & 4.564 & 4.397 & 4.743 & 4.073 & 4.490 \\
\hline $\begin{array}{l}\text { NC Ivaip./ } \\
\text { S.João Ivaí }\end{array}$ & 700 & 835 & 1.157 & 1.400 & 1.050 & 1.600 & 1.020 & 970 & 900 & 950 & 738 & 738 & 738 & 787 & 1.000 & 1.000 & 1.652 \\
\hline $\begin{array}{l}\text { NC-Ivaip./ } \\
\text { S.Pd. Ivaí }\end{array}$ & 4.500 & 3.550 & 4.200 & 3.887 & 5.720 & 6.350 & 3.622 & 7.230 & 7.480 & 7.480 & 8.865 & 8.190 & 8.865 & 9.230 & 7.858 & 7.984 & 8.117 \\
\hline $\begin{array}{l}\text { NC-C.Proc./ } \\
\text { S.Mariana }\end{array}$ & 1.300 & 1.130 & 1.450 & 2.214 & 2.819 & 4.000 & 4.500 & 4.500 & 5.900 & 5.000 & 5.000 & 6.000 & 6.000 & 6.000 & 4.000 & 3.000 & 3.100 \\
\hline $\begin{array}{l}\text { NP-Jacarez/ } \\
\text { Cambará }\end{array}$ & 6.300 & 7.200 & 10.800 & 6.300 & 10.209 & 13.000 & 13.400 & 14.400 & 10.500 & $\begin{array}{r}10.90 \\
6 \\
\end{array}$ & 10.500 & $\begin{array}{r}10.50 \\
0 \\
\end{array}$ & 13.000 & 13.000 & 13.500 & 14.000 & 14.000 \\
\hline $\begin{array}{l}\text { COc-C.Mrão/ } \\
\text { E.Beltrão }\end{array}$ & 3.200 & 2.738 & 3.738 & 4.242 & 5.700 & 5.475 & 6.650 & 6.538 & 7.105 & 7.128 & 7.014 & 7.410 & 7.581 & 8.000 & 8.831 & 8.641 & 8.471 \\
\hline COc-C. Mrão/Fênix & 102 & 102 & & 102 & 102 & 1.438 & 1.438 & 1.265 & 925 & 1.264 & 1.391 & 1.391 & 1.463 & 1.463 & 1.800 & 2.320 & 2.320 \\
\hline
\end{tabular}

continua... 


\begin{tabular}{|c|c|c|c|c|c|c|c|c|c|c|c|c|c|c|c|c|c|}
\hline $\begin{array}{l}\text { PRODUÇÃO } \\
\text { (ton) }\end{array}$ & 1990 & 1991 & 1992 & 1993 & 1994 & 1995 & 1996 & 1997 & 1998 & 1999 & 2000 & 2001 & 2002 & 2003 & 2004 & 2005 & 2006 \\
\hline $\begin{array}{l}\text { NO-Cianorte - } \\
\text { Jussara }\end{array}$ & 205.712 & 155.929 & 208.806 & 220.170 & 233.729 & 273.874 & 260.165 & 262.059 & 288.190 & 301.319 & 238.834 & 238.834 & 253.889 & 241.532 & 287.755 & 260.129 & 300.328 \\
\hline $\begin{array}{l}\text { NO-Pvai/ } \\
\text { Mirador }\end{array}$ & 14.910 & 23.310 & 30.089 & 53.040 & 38.472 & 70.500 & 52.865 & $\mathrm{~S} / \mathrm{D}$ & 141.050 & 84.931 & 58.742 & 77.774 & 139.179 & 116.742 & 137.041 & 136.850 & 214.688 \\
\hline $\begin{array}{l}\text { NO-Cianorte/ } \\
\text { S.Tomé }\end{array}$ & 271.418 & 287.739 & 373.192 & 368.184 & 493.418 & 485.958 & 679.970 & 626.444 & 621.619 & 658.992 & 545.841 & 650.147 & 583.104 & 737.978 & 794.927 & 759.389 & 749.349 \\
\hline $\begin{array}{l}\text { NC-Astorga/ } \\
\text { Itaguajé }\end{array}$ & 945 & 8.924 & 9.388 & 7.903 & 18.424 & S/D & 22.622 & 14.164 & 13.650 & 10.819 & 26.327 & 2.179 & 15.693 & 13.200 & 9.723 & 47.392 & $S / D$ \\
\hline $\begin{array}{l}\text { NC-Astorga/ } \\
\text { Lobato }\end{array}$ & 215.159 & 314.290 & 308.555 & 333.684 & 418.163 & 386.230 & 426.283 & 366.419 & 497.456 & 679.422 & 513.593 & 586.469 & 624.100 & 533.014 & 616.837 & 515.275 & 567.519 \\
\hline $\begin{array}{l}\text { NC-Floraí/ } \\
\text { Itambé }\end{array}$ & 29.400 & 64.209 & 56.244 & 209.668 & 231.564 & 299.100 & 204.039 & 210.233 & 166.277 & 116.520 & 91.943 & 117.119 & 133.534 & 186.246 & 195.488 & 184.644 & 180.900 \\
\hline $\begin{array}{l}\text { NC-Mgá/ } \\
\text { Mandaguarí }\end{array}$ & 34.911 & 37.115 & 35.417 & 26.313 & 11.147 & 33.431 & 39.552 & 21.438 & 29.400 & 28.271 & 19.322 & 30.403 & 41.943 & 48.577 & 119.132 & 110.200 & 104.400 \\
\hline $\begin{array}{l}\text { NC-Maringá/ } \\
\text { Marialva }\end{array}$ & 188.910 & 193.780 & 213.450 & 210.343 & 266.746 & 314.211 & 462.000 & 465.056 & 451.438 & 389.166 & 287.907 & 328.997 & 274.513 & 266.499 & 292.297 & 300.675 & 294.400 \\
\hline $\begin{array}{l}\text { NC-pucarana/ } \\
\text { N. Itacolomi }\end{array}$ & $S / D$ & $\mathrm{~S} / \mathrm{D}$ & $S / D$ & S/D & S/D & S/D & $S / D$ & $S / D$ & S/D & 9.675 & 8.804 & 8.889 & 6.335 & 6.415 & 4.844 & $S / D$ & 11.964 \\
\hline $\begin{array}{l}\text { NC-Londrina/ } \\
\text { Cambé }\end{array}$ & 9.768 & 11.745 & 18.395 & 23.670 & 24.588 & 28.058 & 37.274 & 39.417 & 34.432 & 38.333 & 39.565 & 56.779 & 28.688 & 44.528 & 48.874 & 30.037 & 53.809 \\
\hline $\begin{array}{l}\text { NC-Ldna/ } \\
\text { Pitangueiras }\end{array}$ & $S / D$ & S/D & $S / D$ & 14.708 & 14.612 & 14.823 & 7.322 & 19.311 & 20.866 & 13.268 & 5.164 & 18.582 & 18.845 & 32.064 & 41.847 & 27.540 & 32.280 \\
\hline $\begin{array}{l}\text { NC-Londrina/ } \\
\text { Rolândia }\end{array}$ & 249.389 & 307.047 & 384.412 & 363.399 & 359.450 & 380.109 & 445.541 & 355.897 & 372.342 & 367.643 & 358.252 & 402.618 & 454.574 & 437.229 & 480.784 & 338.670 & 428.683 \\
\hline $\begin{array}{l}\text { NC-Ivaip./ } \\
\text { S,João Ivaí }\end{array}$ & 56.000 & 77.237 & 115.700 & 126.000 & 91.300 & 128.000 & 85.680 & 77.600 & 72.000 & 76.000 & 58.863 & 59.040 & 64.944 & 81.061 & 95.000 & 85.000 & 140.420 \\
\hline $\begin{array}{l}\text { NC-Ivaip./ } \\
\text { S.Pedro Ivaí }\end{array}$ & 382.500 & 349.905 & 411.600 & 366.160 & 454.582 & 539.750 & 304.248 & 578.400 & 598.400 & 598.400 & 704.768 & 747.952 & 780.120 & 909.035 & 744.794 & 644.109 & 721.195 \\
\hline $\begin{array}{l}\text { NC-C.Proc/ } \\
\text { S.Mariana }\end{array}$ & 96.200 & 98.310 & 116.000 & 188.190 & 239.615 & 360.000 & 405.000 & 405.000 & 501.500 & 425.000 & 425.000 & 540.000 & 510.000 & 540.000 & 380.000 & 270.000 & 263.500 \\
\hline $\begin{array}{l}\text { NP-Jacarez/ } \\
\text { Cambará }\end{array}$ & 491.400 & 576.000 & 756.000 & 491.400 & 735.000 & 1.170 .000 & 1.045 .200 & 1.123 .200 & 987.000 & 1.025 .164 & 888.300 & 1.050 .000 & 1.196 .000 & 1.300 .000 & 1.188 .000 & 1.120 .000 & 1.260 .000 \\
\hline $\begin{array}{l}\text { COc-C.Mrão- } \\
\text { E.Beltrão }\end{array}$ & 288.000 & 268.324 & 366.324 & 448.549 & 524.400 & 509.175 & 519.698 & 604.765 & 689.398 & 530.252 & 539.797 & 652.080 & 592.607 & 800.000 & 814.218 & 673.998 & 779.332 \\
\hline $\begin{array}{l}\text { COc-C.Mrão- } \\
\text { Fênix }\end{array}$ & 10.200 & 10.200 & $\mathrm{~S} / \mathrm{D}$ & 9.180 & 122.230 & 162.214 & 123.869 & 80.360 & 80.360 & 114.951 & 143.031 & 143.031 & 143.374 & 143.374 & 176.400 & 178.640 & 208.800 \\
\hline
\end{tabular}

Org.: Domingues, I.A.S. (2007). Fonte: IBGE/SIDRA/PAM (2007). 
Os valores médios de área, de produção e de produtividade, dos 17 municípios, representaram, em relação aos valores médios das mesorregiões e das 18 microrregiões, percentuais em torno de $0,4 \%$ e $7,3 \%$ da área plantada, $0,5 \%$ e $8,5 \%$ da quantidade produzida respectivamente. Quanto ao rendimento médio, os valores foram de 20 ton/ha a mais que o das mesorregiões e 13 ton/ha a mais que 0 das microrregiões. Esses valores em termos percentuais foram maiores, $28 \%$ e $16 \%$ (Tabela 9, 12 e 14).

Tabela 14 - Valores médios de área plantada, de produção (Prod) e de produtividade (Produt) da cana-de-açúcar, período de 1990 a 2006 nos municípios com produtividade em torno de 80 ton/ha.

\begin{tabular}{|c|c|c|c|c|}
\hline Meso/microrregião/município & $\begin{array}{l}\text { Área } \\
\text { (ha) }\end{array}$ & Prod (ton) & $\begin{array}{l}\text { Produt média } \\
\text { (ton/ha) }\end{array}$ & Origem do solo \\
\hline NE-Cianorte-Jussara & 2.722 & 248.897 & 91,43 & $\begin{array}{c}\text { Transição } \\
\text { basalto/arenito }\end{array}$ \\
\hline NE-Cianorte-São Tomé & 6.689 & 569.863 & 85,20 & $\begin{array}{c}\text { Transição } \\
\text { basalto/arenito }\end{array}$ \\
\hline NE-Pvai-Mirador & 1.058 & 86.886 & 82,12 & Arenito \\
\hline NC-Astorga-Itaguajé & 215 & 19.352 & 90,01 & Basalto \\
\hline NC-Astorga-Lobato & 5.412 & 464.851 & 85,89 & Basalto \\
\hline NC-Floraí-Itambé & 1.738 & 157.478 & 90,61 & Basalto \\
\hline NC-Maringá-Mandaguari & 499 & 45.351 & 90,80 & Basalto \\
\hline NC-Maringá-Marialva & 3.250 & 305.905 & 94,12 & Basalto \\
\hline NC-Apucarana-Novo Itacolomi* & 80 & 8.132 & 101,65 & Basalto \\
\hline NC-Londrina-Cambé & 353 & 33.409 & 94,75 & Basalto \\
\hline NC-Londrina-Pitangueiras & 231 & 20.088 & 86,96 & Basalto \\
\hline NC-Londrina-Rolândia & 4.027 & 381.532 & 94,74 & Basalto \\
\hline NC-Ivaiporã-São João do Ivaí & 1.014 & 87.638 & 86,44 & Basalto \\
\hline NC-Ivaiporã São Pedro do Ivaí & 6.655 & 578.583 & 86,95 & Basalto \\
\hline NP-C.Proc.- Santa Mariana & 3.877 & 339.019 & 87,44 & Basalto \\
\hline NP-Jacarezinho-Cambará & 11.266 & 964.863 & 85,65 & Basalto \\
\hline C.Oc-Cpo-Mourão Eng. Beltrão & 6.380 & 564.760 & 88,52 & Basalto \\
\hline CO-Campo Mourão-Fênix & 1.180 & 108.836 & 92,20 & Basalto \\
\hline
\end{tabular}

NO (Noroeste), NC (Norte Central), NP (Norte Pioneiro), COc (Centro Ocidental)

* Série de dados incompletos - Início do cultivo em 1999.

Org.: Domingues, I.A.S. (2007).

Solo em área de transição geológica

Solo predominante do arenítico

Solo predominante basáltico

A representatividade numérica ou mesmo quantitativa dos itens analisados em diferentes escalas, mesorregiões, microrregiões e municípios, direcionou a uma pesquisa com apenas 2 municípios, entendendo-se serem esses municípios, 
descritos nos próximos tópicos, representativos de um todo, ou seja, das regiões mais favoráveis ao cultivo da cana-de-açúcar.

\section{3 - Tendência tecnológica na produtividade da cana-de-açúcar nos municípios de Mirador e Cambé, PR}

As tecnologias tais como melhoramento genético, variedades mais resistentes a pragas ou a secas, manejo de solo, equipamentos modernos etc. são técnicas empregadas com a finalidade, sobretudo, de proporcionar melhorias à produtividade das culturas.

Para verificar a real relação do clima com a produtividade do cultivo da canade-açúcar, objetivou-se retirar os efeitos das tecnologias adotadas no sistema de produção desse cultivo ao longo do tempo. Para tal, empregou-se a técnica de retirada tecnológica, descrita no item Procedimentos Metodológicos, na série de dados original de produtividade, obtendo-se a nova série de dados (Tabela 15), as quais foram correlacionadas aos dados de precipitação.

Após a retirada da tendência tecnológica, observou-se que, na média, a produtividade corrigida teve uma redução de 7,7 ton/ha em Cambé e de 3,6 ton/ha em Mirador.

A variação interanual da produtividade original da cana-de-açúcar (com tendência) e a corrigida (sem tendência) estão ilustradas na Figura (27) para os municípios de Cambé e Mirador, PR, para o período de 1982 a 2006.

Em Cambé nota-se, por meio das linhas de produtividade, uma aproximação dos valores entre a produtividade original e a corrigida de 1982 até 1988 . O maior distanciamento é observado a partir de 1997.

Em Mirador as linhas de produtividade, original e corrigida, se mantiveram bem próximas até o ano de 1991, embora os maiores distanciamentos ocorressem a partir de 2000. 
Tabela 15 - Dados originais (sem correção) de produtividade da cana-de-açúcar e nova série de dados de produtividade (corrigidos) dos municípios de Cambé e Mirador, PR, no período de 1982 a 2006.

\begin{tabular}{|c|c|c|c|c|}
\hline \multirow{3}{*}{ Ano } & \multicolumn{4}{|c|}{ Produtividade (ton/ha) } \\
\hline & \multicolumn{2}{|c|}{ Cambé } & \multicolumn{2}{|c|}{ Mirador } \\
\hline & Sem correção & Corrigida & Sem correção & Corrigida \\
\hline 1982 & 115,6 & 115,6 & 78,1 & 78,1 \\
\hline 1983 & 91,4 & 90,8 & 79,8 & 79,5 \\
\hline 1984 & 58,8 & 57,6 & 63,0 & 62,4 \\
\hline 1985 & 70,8 & 68,9 & 80,0 & 79,1 \\
\hline 1986 & 83,2 & 80,7 & 80,0 & 78,8 \\
\hline 1987 & 82,4 & 79,2 & 75,1 & 73,6 \\
\hline 1988 & 82,4 & 78,6 & 72,0 & 70,2 \\
\hline 1989 & 70,8 & 66,4 & 91,0 & 89,0 \\
\hline 1990 & 74,0 & 68,9 & 70,3 & 68,0 \\
\hline 1991 & 87,0 & 81,3 & 70,0 & 67,4 \\
\hline 1992 & 103,9 & 97,6 & 80,2 & 77,3 \\
\hline 1993 & 90,0 & 83,0 & 80,0 & 76,8 \\
\hline 1994 & 82,5 & 74,9 & 84,0 & 80,5 \\
\hline 1995 & 98,5 & 90,2 & 100,0 & 96,2 \\
\hline 1996 & 111,6 & 102,7 & 88,9 & 84,7 \\
\hline 1997 & 87,6 & 78,0 & 82,1 & 77,7 \\
\hline 1998 & 97,8 & 87,6 & 91,0 & 86,3 \\
\hline 1999 & 100,1 & 89,2 & 82,1 & 77,1 \\
\hline 2000 & 90,3 & 78,8 & 59,6 & 54,3 \\
\hline 2001 & 103,2 & 91,1 & 74,0 & 68,4 \\
\hline 2002 & 88,0 & 75,2 & 82,1 & 76,2 \\
\hline 2003 & 116,3 & 102,8 & 71,4 & 65,2 \\
\hline 2004 & 102,9 & 88,8 & 86,7 & 80,2 \\
\hline 2005 & 72,7 & 58,0 & 84,8 & 78,0 \\
\hline 2006 & 89,7 & 74,3 & 88,2 & 81,2 \\
\hline Média & 90,1 & 82,4 & 79,8 & 76,2 \\
\hline Diferença & - & 7,7 & - & 3,6 \\
\hline
\end{tabular}

Org.: Domingues, I.A.S. (2007).

Em Cambé a menor diferença de um ano a outro foi de 0,6 ton/ha e a maior de 15,3 ton/ha, enquanto que em Mirador foi de 0,3 ton/ha e 7,1 ton/ha. Portanto, a variação interanual foi mais evidenciada para o primeiro município.

Esses aumentos significativos ao longo do tempo poderiam ser explicados também pela incorporação de novas tecnologias (melhoramento genético, insumos, mecanização) no sistema de produção da cultura, principalmente a partir do final da década de 1980 em Cambé e do início da de 1990 em Mirador. 
$\mathrm{Na}$ série corrigida (sem tendência tecnológica), a variação interanual é decorrente de outros fatores de natureza não tecnológica, que pode ser por influência da variabilidade climática. Esta, porém, será discutida mais adiante (item sobre correlação climática e produtividade).
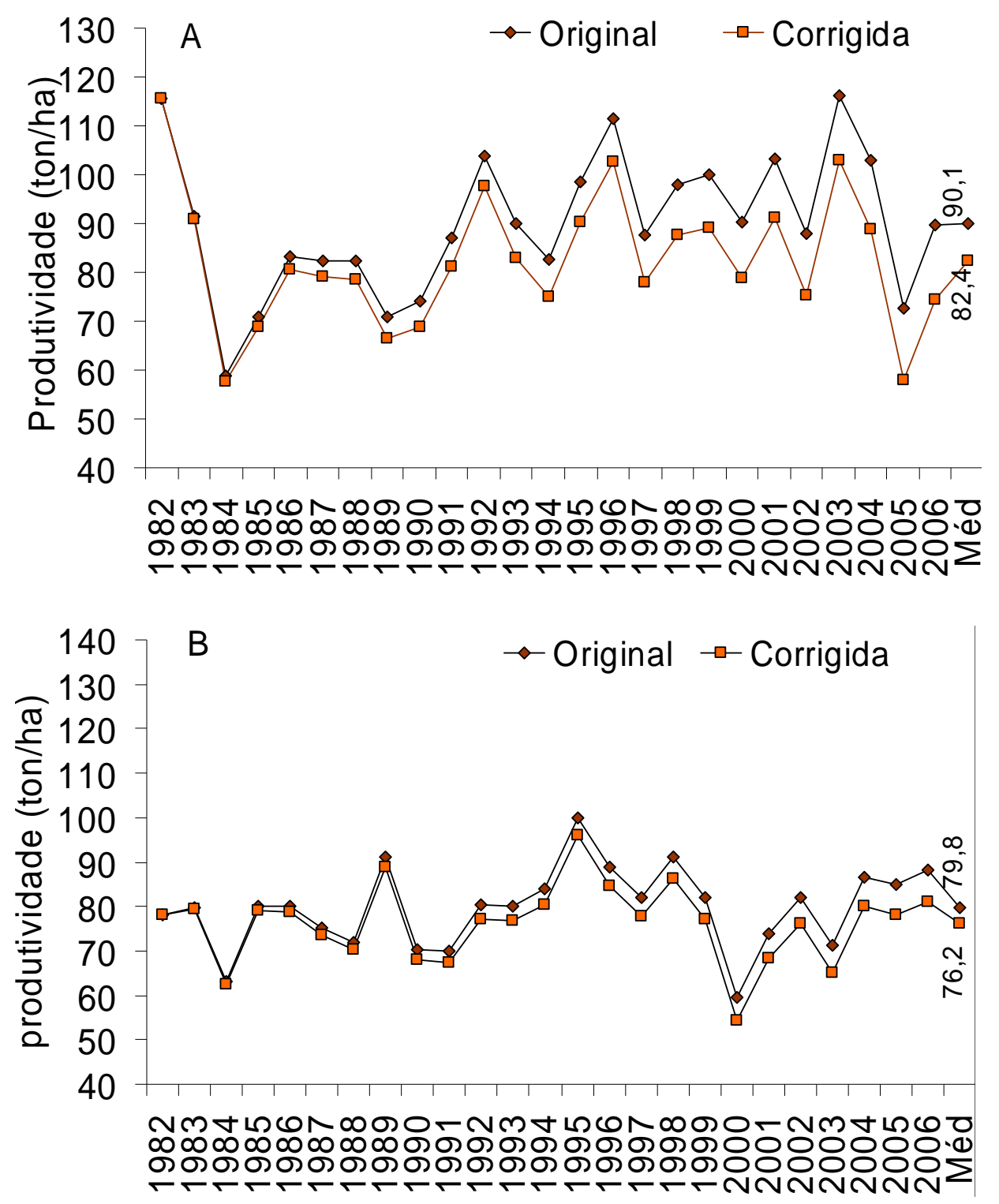

Figura 27 - Variação interanual da produtividade original (sem correção) e sem tendência tecnológica (corrigida) da cana-de-açúcar nos municípios de Cambé (A) e Mirador (B), período 1982 a 2006. Org.: Domingues, I.A.S. (2008). 


\section{4 - Análise dos dados de área plantada, produção e produtividade da cana- de-açúcar dos municípios de Cambé e Mirador, PR}

Dos municípios localizados em solos predominantemente de Basalto e Arenito e que apresentaram as maiores produtividades, optou-se por detalhar a pesquisa da cultura da cana-de-açúcar nos municípios de Mirador e Cambé (Tabela 14). Estes, além de estarem localizados em solos distintos, apresentaram dados completos de área plantada, quantidade produzida, rendimento de cana-de-açúcar, em todos os anos do período analisado (Tabela 16).

Tabela 16 - Dados de área plantada, produção, produtividade e desvio de produtividade da cana-deaçúcar para os municípios de Mirador e Cambé, PR.

\begin{tabular}{|c|c|c|c|c|c|c|c|c|}
\hline \multirow[b]{3}{*}{ Ano } & \multicolumn{8}{|c|}{ Município } \\
\hline & \multicolumn{4}{|c|}{ Cambé } & \multicolumn{4}{|c|}{ Mirador } \\
\hline & $\begin{array}{l}\text { Área } \\
\text { (ha) }\end{array}$ & $\begin{array}{l}\text { Prod } \\
\text { (ton) }\end{array}$ & $\begin{array}{l}\text { Produt } \\
\text { (ton/ha) }\end{array}$ & Desvio & \begin{tabular}{|l} 
Área \\
(ha)
\end{tabular} & $\begin{array}{l}\text { Prod } \\
\text { (ton) }\end{array}$ & \begin{tabular}{|l|} 
Produt \\
(ton/ha)
\end{tabular} & Desvio \\
\hline 1982 & 45 & 5.580 & 115,6 & 33,2 & 52 & 4.059 & 78,1 & 1,9 \\
\hline 1983 & 60 & 6.934 & 90,8 & 8,4 & $248^{*}$ & $19.914^{*}$ & 79,5 & 3,3 \\
\hline 1984 & 92 & 5.411 & 57,6 & $-24,8$ & 170 & 10.705 & 62,4 & $-13,8$ \\
\hline 1985 & 110 & 10.642 & 68,9 & $-13,5$ & 250 & 20.000 & 79,1 & 2,9 \\
\hline 1986 & 119 & 9.698 & 80,7 & $-1,8$ & 235 & 18.800 & 78,8 & 2,6 \\
\hline 1987 & 114 & 9.388 & 79,2 & $-3,2$ & 172 & 12.913 & 73,6 & $-2,6$ \\
\hline 1988 & 83 & 6.836 & 78,6 & $-3,8$ & 145 & 10.512 & 70,2 & $-6,0$ \\
\hline 1989 & 95 & 6.727 & 66,4 & $-16,0$ & 172 & 15.655 & 89,0 & $\overline{12,8}$ \\
\hline 1990 & 132 & 9.768 & 68,9 & $-13,5$ & 212 & 14.910 & 68,0 & $-8,2$ \\
\hline 1991 & 135 & 11.745 & 81,3 & $-1,1$ & 333 & 23.310 & 67,4 & $-8,8$ \\
\hline 1992 & 177 & 18.395 & 97,6 & 15,2 & 375 & 30.089 & 77,3 & 1,1 \\
\hline 1993 & 263 & 23.670 & 83,0 & 0,6 & 663 & 53.040 & 76,8 & 0,6 \\
\hline 1994 & 298 & 24.588 & 74,9 & $-7,5$ & 458 & 38.472 & 80,5 & 4,3 \\
\hline 1995 & 285 & 28.058 & 90,2 & 7,8 & 705 & 70.500 & 96,2 & 20,0 \\
\hline 1996 & 334 & 37.274 & 102,7 & 20,3 & 595 & 52.865 & 84,7 & 8,5 \\
\hline 1997 & 450 & 39.417 & 78,0 & $-4,4$ & $788^{\#}$ & $64.471^{\#}$ & 77,7 & 1,5 \\
\hline 1998 & 352 & 34.432 & 87,6 & 5,2 & 1.550 & 141.050 & 86,3 & 10,1 \\
\hline 1999 & 383 & 38.333 & 89,2 & 6,8 & 1.035 & 84.931 & 77,1 & 0,9 \\
\hline 2000 & 438 & 39.565 & 78,8 & $-3,6$ & 986 & 58.742 & 54,3 & $-21,9$ \\
\hline 2001 & 550 & 56.779 & 91,1 & 8,7 & 1.051 & 77.774 & 68,4 & $-7,8$ \\
\hline 2002 & 326 & 28.688 & 75,2 & $-7,2$ & 1.696 & 139.179 & 76,2 & 0,0 \\
\hline 2003 & 383 & 44.528 & 102,8 & 20,4 & 1.635 & 116.742 & 65,2 & $-11,0$ \\
\hline 2004 & 475 & 48.874 & 88,8 & 6,4 & 1.581 & 137.041 & 80,2 & 4,0 \\
\hline 2005 & 413 & 30.037 & 58,0 & $-24,4$ & 1.614 & 136.850 & 78,0 & 1,8 \\
\hline 2006 & 600 & 53.809 & 74,3 & $-8,1$ & 2.433 & 214.688 & 81,2 & 5,0 \\
\hline Média & 268 & 25.167 & 82,4 & & 788 & 64.471 & 76,2 & \\
\hline
\end{tabular}

$\left(^{*}\right)$ Dados preenchidos pela média dos anos de 1982 a 1990 $(\#)$ Dados preenchidos pela média dos anos de 1991 a 2006

Org.: Domingues, I.A.S. (2007). 
O município de Cambé, pertencente à microrregião de Londrina, na mesorregião Norte Central, está sobre solos originados do basalto, terra roxa, e apresenta clima Cwa - clima temperado, quente, mês de menor precipitação inferior a 60mm, (NOGAROLLI, 2007), posição latitudinal média de 2316’33”S. Assentado sobre solos arenoso, o município de Mirador apresenta clima tipo Cfa - classificação segundo Koeppen - sempre úmido, clima pluvial quente-temperado, alterando em alguns anos com Cwa, seco no inverno (MAACK, 2002) e está posicionado na latitude de 2324'38'S, da região de Paranavaí e mesorregião Noroeste paranaense.

O comportamento anual da cultura da cana-de-açúcar no que diz respeito aos itens área plantada, produção e produtividade dos municípios de Mirador e Cambé, está representado na Tabela 16 e na Figura 28.

Quanto à área plantada, observou-se que no início do período esta era de 52ha em Mirador e de 45ha em Cambé, chegando a 2006 com área de 2.433ha e 600 ha respectivamente. Portanto, o aumento, no período, foi de 2.381 ha para o primeiro município e de 555ha para o segundo.

As maiores reduções interanuais em área plantada tiveram a seguinte variação: em Mirador as reduções foram de 205ha no ano de 1993/94; 515ha no de ano 1998/99. Em Cambé as reduções aconteceram nos anos agrícolas de 1997/98 e 2001/02, com valores de 98ha e 224ha, respectivamente (Figura 28 A). Percebe-se com isso que as maiores variações ocorreram em 1998/99 em Mirador e 2001/02 em Cambé. Quanto aos maiores aumentos, verificou-se em Mirador um aumento de 645ha no ano de 2002 e 819ha em 2006. Em Cambé esses aumentos ocorreram em 1997 com 116ha e em 2006 com 187ha.

A área plantada com cana-de-açúcar, em Mirador e em Cambé, correspondeu à média do total das mesorregiões, 2,4\% e 0,58\%. Para a área do município de Mirador, com relação à da sua mesorregião, Noroeste paranaense, o percentual foi de $1,28 \%$ e na área de Cambe, em relação à da sua mesorregião, Norte Central, o valor percentual foi de 0,45\%; As áreas plantadas desses municípios, quando relacionadas ao total médio da área das suas microrregiões, representaram percentuais de $7,3 \%$ e $13,0 \%$, respectivamente.

A análise comparativa das três variáveis de produção mostrou que as maiores variações ocorreram nos seguintes anos agrícolas (Figura 28): 
Em Mirador houve dois anos agrícolas (1990/91 e 2005/06) que apresentaram aumento de área e queda na produção e um ano (2004/05) com redução de área e aumento de produção (Figura 28 A e 28 B); Em Cambe, no ano de 1985/86, houve aumento de área plantada e redução na produtividade, e em 1994/95 ocorreu o contrário, diminuiu a área e aumentou a produtividade (Figura 28 A e 28 B). Esse tipo de variação, nesses anos, é passível de verificação de possíveis influências climáticas, já que é comum ocorrer aumento ou redução de área e consequentemente aumento ou redução da produção.

Quanto à produtividade, em Mirador os maiores valores ocorreram nos anos agrícolas de 1988/89 e 1994/95, com desvio positivo em relação à média de 12,8 ton/ha e 20,0 ton/ha, respectivamente. Os valores menores aconteceram em 1983/84, com desvio negativo de 13,8 ton/ha, e no ano de 1999/2000, com desvio negativo de 21,9 ton/ha (Figura 28C e Tabela 16). Assim, o maior índice de aumento na produtividade foi de $26,24 \%$ e de redução $27,75 \%$.

Em Cambé as maiores produtividades ocorreram nos anos agrícolas de 1981/82, 1995/96 e 2002/03, com valores de 115,6 ton/ha, 102,7 ton/ha e 102,8 ton/ha, respectivamente. E as menores nos anos de 1983/84, com 57,6 ton/ha, e 2004/05, com 58,0 ton/ha (Figura 28 C). Para esses três primeiros anos os desvios em relação à média foram de $+33,2,+20,3$ e $+20,4$ ton/ha e para as duas últimas de $-24,4$ e $-24,8$ ton/ha (Tabela 16).

A partir dessa análise percebeu-se que em alguns anos agrícolas ocorreram variações ora na produção, ora na produtividade, ou nas duas simultaneamente, em especial para o rendimento. Uma possível explicação para esse fato seria a ocorrência de adversidades climáticas. 

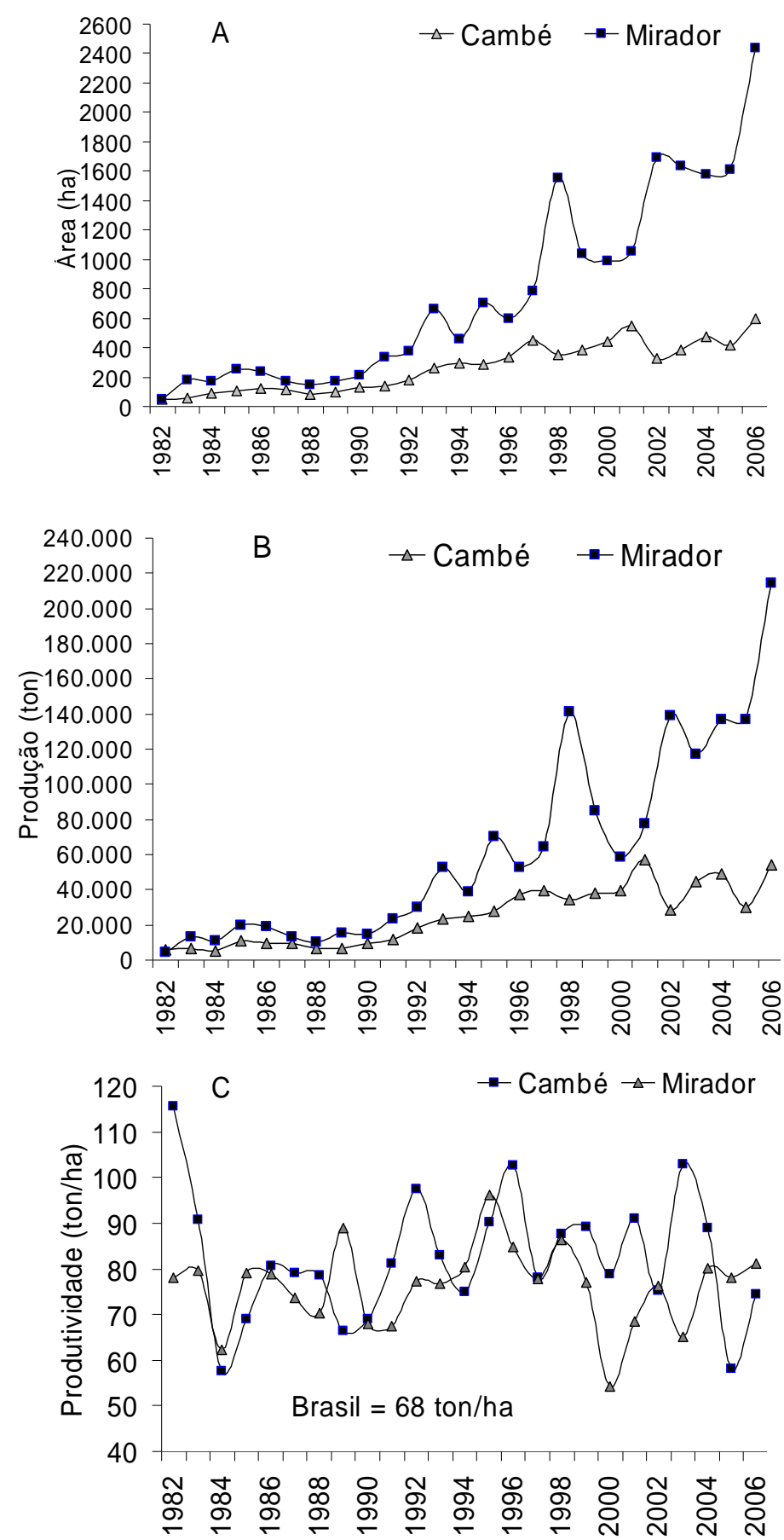

Figura 28 - Área plantada $(A)$, produção $(B)$ e produtividade $(C)$ da cana-de-açúcar nos municípios de Mirador e Cambé, PR, no período de 1982 a 2006. Org.: Domingues, I.A.S. (2007).

Diante do exposto, foi possível, além do acompanhamento da evolução quantitativa da cultura da cana-de-açúcar, verificar que, dentre os níveis escalares utilizados, no que diz respeito principalmente à produtividade, o nível de detalhe nos dá uma resposta numérica dos dados mais próxima da realidade da cultura (Figura 29). 


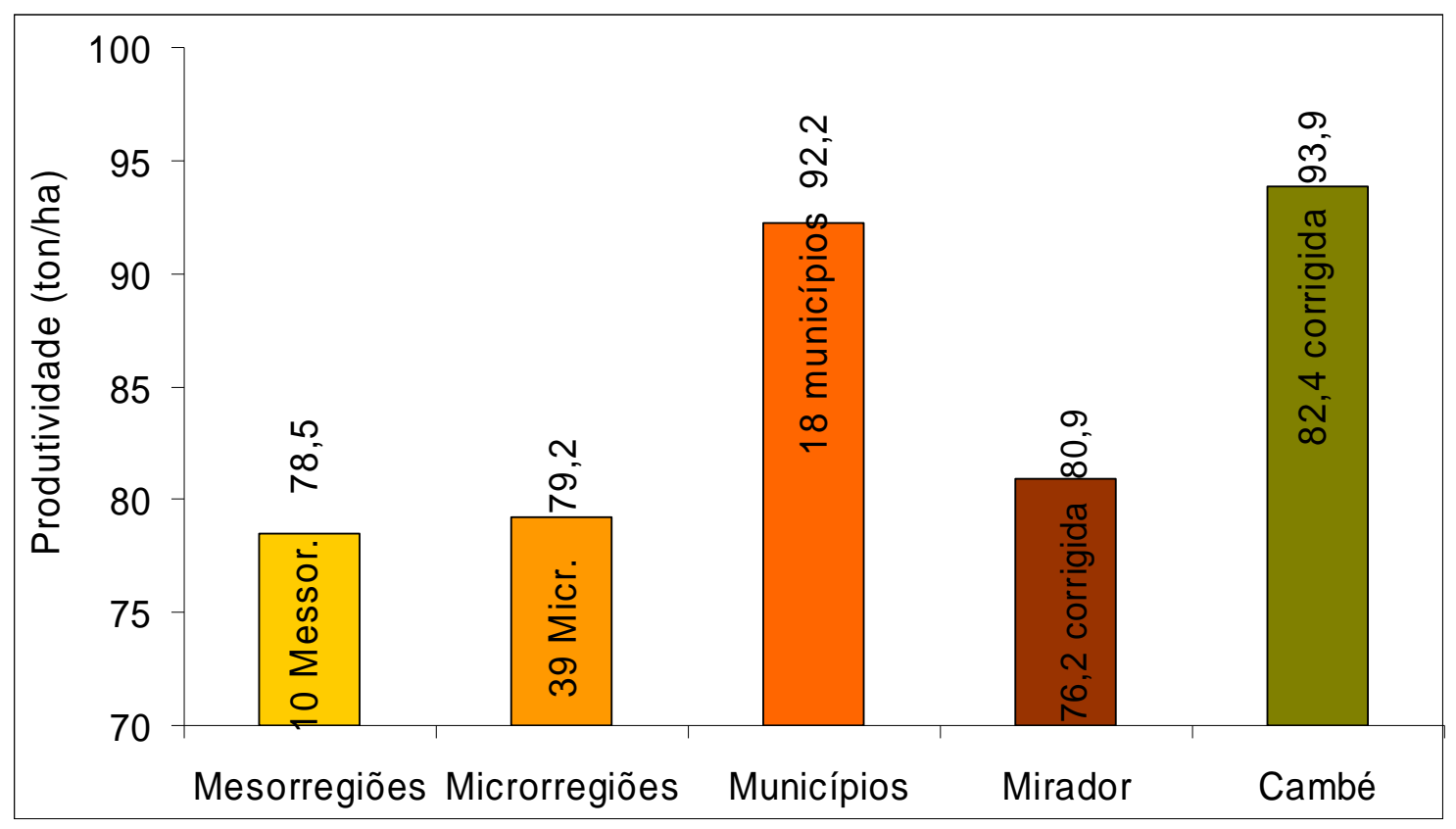

Figura 29 - Valores médios de produtividade em diferentes escalas regionais para o período estudado: mesorregiões paranaenses; microrregiões com rendimento acima 79ton/ha; municípios com valores de 85 ton/ha; e 2 municípios em solos distintos com os melhores rendimentos.

Org.: Domingues, I.A.S. (2007).

Dessa forma, verificou-se, mediante a análise da evolução da cultura da canade-açúcar no estado do Paraná, que a região onde está concentrada o maior cultivo se localiza entre os paralelos de aproximadamente 22ํㅜㅇ's e 24오 de latitude, e é justamente nessa faixa onde estão as 4 mesorregiões com maiores produtividades do estado. Inseridas nessas mesorregiões, 18 microrregiões se destacaram, com produtividades acima de 79,0 ton/ha; dentre essas, 18 municípios tiveram média em torno de 92,0 ton/ha, e em nível de escala de detalhe os municípios de Mirador e Cambé foram os que obtiveram as maiores médias de produtividade, 82,1 (valor com correção tecnológica 76,2 ton/ha) e 94,7 ton/ha (com correção 82,4 ton/ha), respectivamente. 


\section{5 - Mapeamento da evolução espaço-temporal das variáveis de produção da cultura de cana-de-açúcar em escalas de mesorregióes, microrregiões e municípios}

O mapeamento da evolução espaço-temporal da cultura da cana-de-açúcar foi efetuado por intervalo temporal de quatro em quatro anos (1990/94/98/2002/06) e entre esses intercalados dois anos (2000 e 2005) que apresentaram valores das variáveis fora do padrão habitual do período estudado. De acordo com a metodologia adotada, os intervalos de classes dessas três variáveis foram em número de seis. A primeira classe designada de alta, a segunda de média alta, a terceira de média, a quarta de média baixa, a quinta de baixa e a sexta de muito baixa, conforme descrito no item 3.2.

4.5.1 - Mapeamento por mesorregiões das variáveis área plantada, produção e produtividade

Conforme a Figura 30, a variável área plantada teve uma evolução temporal sequencial principalmente nas 4 mesorregiões de maior cultivo da cana-de-açúcar, conforme os intervalos de tempo determinados.

No ano de 1990 a mesorregião com maior área plantada foi a Norte Central, inserida na quarta classe, com área média baixa (64 mil ha a 94 mil ha), seguida da Norte Pioneiro, na classe baixa área (32 mil ha a 64 mil ha).

Em 1994 a mesorregião Norte Central elevou sua área para a terceira classe de média área (96 mil ha a 138 mil ha) e a Noroeste subiu para a classe baixa (32 mil ha a 64 mil ha). As demais permaneceram com a mesma área do ano de 1990.

Em 1998 a mesorregião Noroeste passou para a classe de média área e a Norte Pioneiro para a quarta classe, média baixa (32 mil ha a $64 \mathrm{mil} \mathrm{ha).} \mathrm{As} \mathrm{outras}$ mesorregiões permaneceram com as mesmas áreas do ano de 1994. A área plantada do ano inserido, 2000, ficou exatamente como a de 1998.

Em 2002 apenas a mesorregião Noroeste mudou de classe, passando da terceira para a segunda classe, média alta (128 mil ha a 160 mil ha), e as áreas das 
demais mesorregiões permaneceram iguais às do ano de 1998. Para o ano inserido de 2005 teve mudança em área plantada apenas a mesorregião Noroeste, passando para a primeira classe.

No último ano da série estudada, 2006, a mesorregião Noroeste era a maior em área plantada, permanecendo na primeira classe (>160 mil ha), seguida da Norte Central, que passou da terceira para a segunda classe de área plantada (128 mil ha a 160 mil ha). As demais permaneceram inalteradas.

A produção concentrou-se principalmente nas mesorregiões Norte Central, Noroeste e Norte Pioneiro, com valores, para os anos determinados, acima de 300 mil ton (Figura 31).

No ano de 1990 a produção da mesorregião Norte Central foi média alta (5 milhões ton a 8,6 milhões ton), seguida da Noroeste, Norte Pioneiro e CentroOcidental, com média produção (300 mil/ton a 4,2 milhões ton). Em 1994 os valores de produção dessas mesorregiões continuaram nas mesmas classes. Nas demais mesorregiões os valores ficaram abaixo de $140 \mathrm{mil} / \mathrm{ton}$, ou seja, com baixa produção.

Para o ano de 1998 as regiões Norte Central, Norte Pioneiro e Noroeste aumentaram a produção. Passaram para a classe alta e média alta respectivamente. Entretanto, as demais mesorregiões continuaram nas mesmas classes de produção.

A única mudança ocorrida em 2000 foi na mesorregião Norte Central, pelo rebaixamento da classe de alta produção para a classe de média alta produção. Nas demais mesorregiões as classes de valores continuaram os mesmos do ano de 1998.

Em 2002 houve mudança de classe nas mesorregiões Noroeste e Norte Central. Essas voltam para a classe de alta produção (9 milhões ton a 15 milhões ton), enquanto as outras mesorregiões continuam nas mesmas classes de produção de 1998, com exceção da mesorregião Oeste, que rebaixou uma classe.

Para os anos de 2005 e 2006 a situação das quantidades produzidas foi à mesma daquela do ano de 2002, em todas as mesorregiões, com exceção da mesorregião Centro Oriental, que saiu da posição de classe de muito baixa produção para a de baixa produção. 


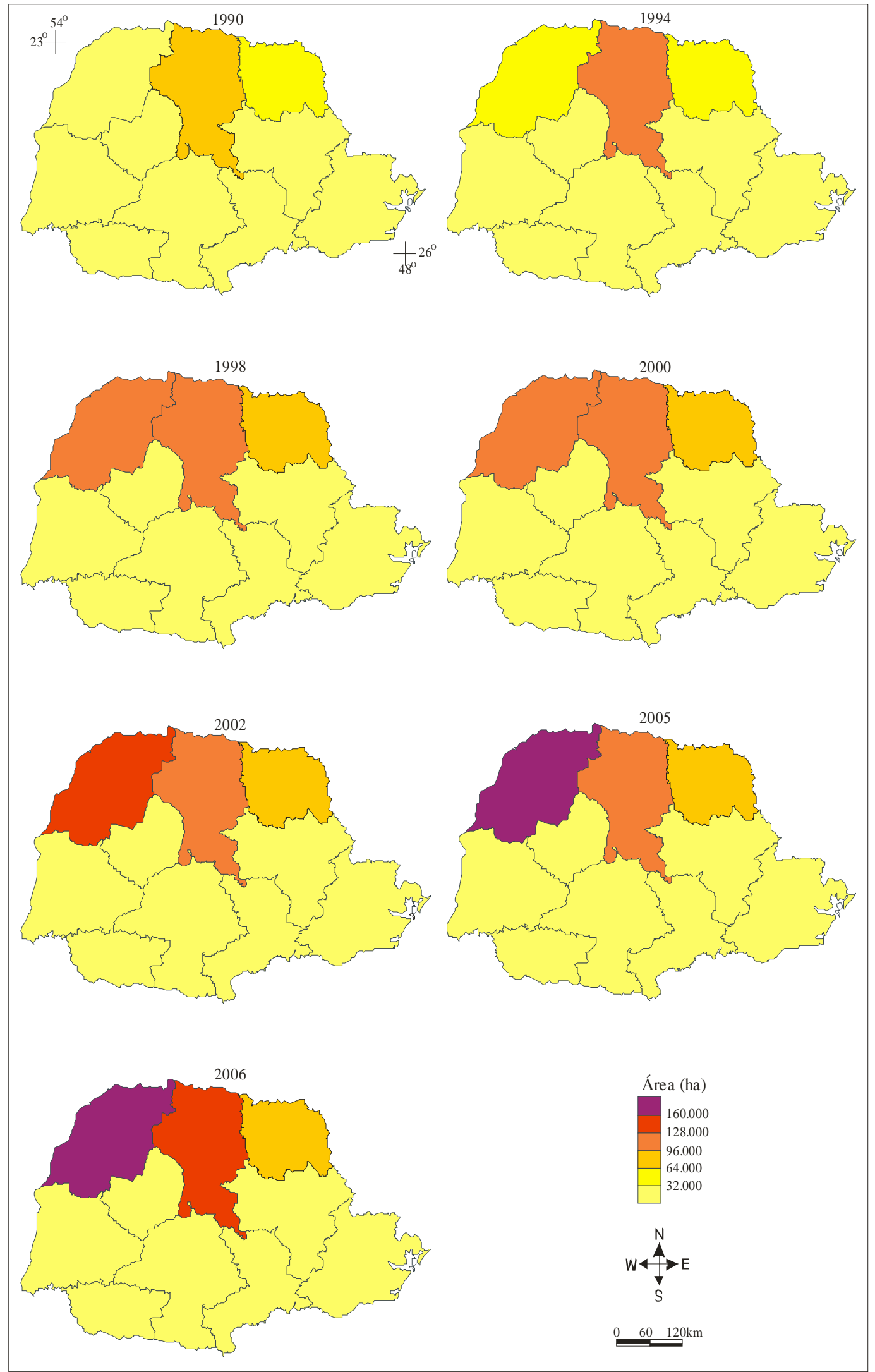

Figura 30- Área plantada com cana-de-açúcar nas mesorregiões paranaenses, para os anos de 1990, 1994, 1998, 2000, 2002, 2005 e 2006. Org.: Domingues, I.A.S. (2008). 

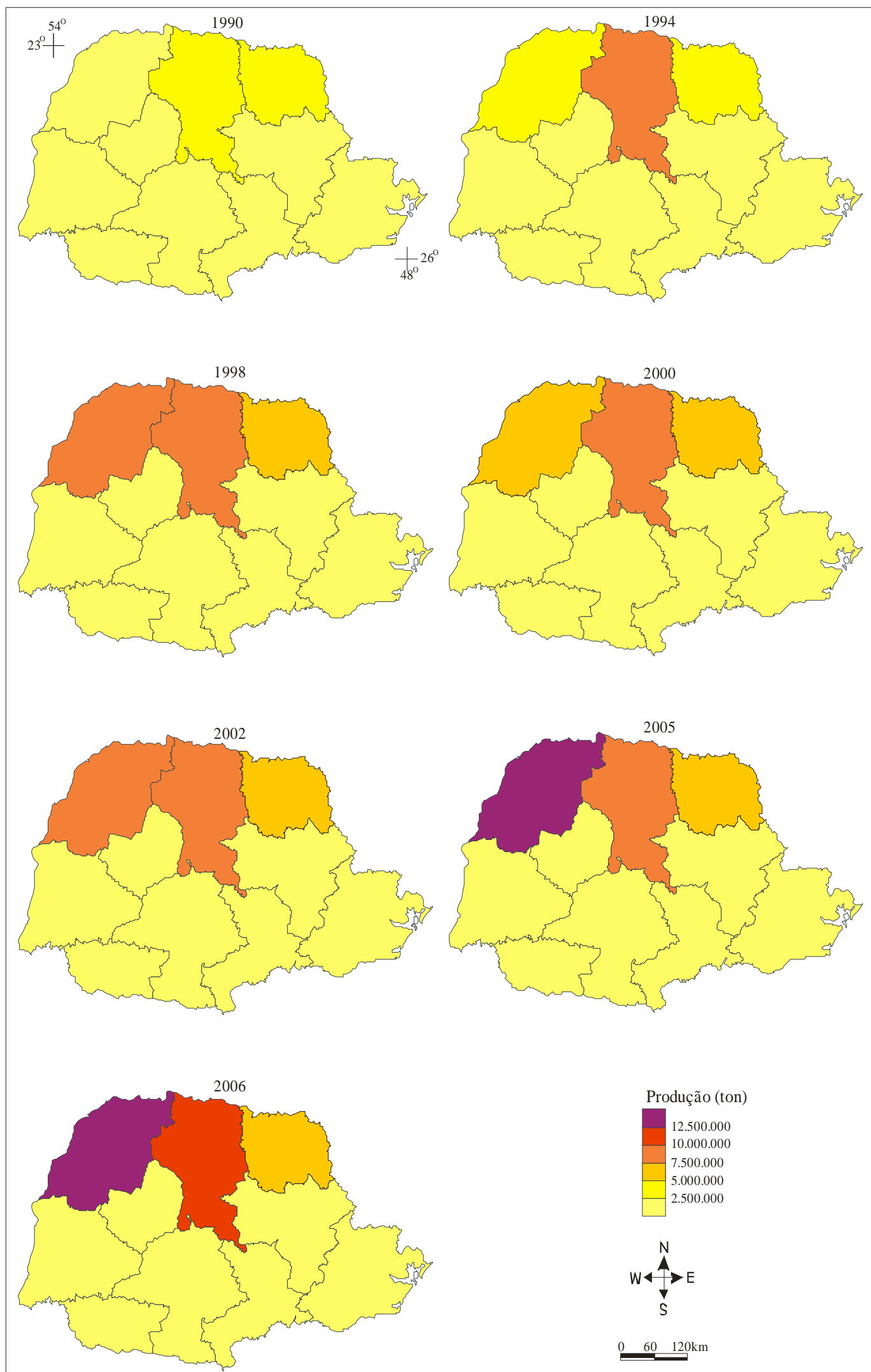

\begin{tabular}{rr}
$0 \quad 60 \quad 120 \mathrm{~km}$ \\
\hline
\end{tabular}

Figura 31 - Produção de cana-de-açúcar nas mesorregiões paranaenses para os anos de 1990, 1994, 1998, 2002, 2005 e 2006.

Org.: Domingues, I.A.S. (2008). 
A evolução espaço-temporal da produtividade de quatro em quatro anos, a começar por 1990, até 2006 teve o seguinte comportamento (Figura 32):

Com relação à produtividade para o primeiro ano do período, 1990, as 4 mesorregiões (Noroeste, Norte Central, Norte Pioneiro e Centro-Ocidental) de maior cultivo da cana-de-açúcar se enquadraram na segunda e terceira classes, com produtividade média a média alta (62 ton/ha a 84 ton/ha). Entretanto, a produtividade das mesorregiões Noroeste e Norte Central esteve na segunda classe, com produtividade média alta (73 ton/ha a 84 ton/ha). As demais 5 Mesorregiões se enquadraram na quinta e sexta classes, ou seja, produtividade baixa e muito baixa (40ton a 51 ton/ha e $<40$ ton/ha).

O ano de 1994 apresentou-se pouco variável em relação a 1990. Apenas as mesorregiões Centro-Ocidental e Norte Pioneiro passaram a ter a mesma produtividade que as mesorregiões Noroeste e Norte Central, ou seja, as 4 mesorregiões de maior cultivo da cana-de-açúcar estão na segunda classe, média produtividade (73 ton/ha a 84 ton/ha). As mesorregiões Oeste e Sudoeste mudaram de classe. A mesorregião Oeste subiu para a segunda classe (40 ton/ha a 51 ton/ha) e a Sudoeste desceu para a primeira classe, produtividade muito baixa ( $<40$ ton/ha).

Em termos de produtividade, o ano de 1998 foi, de modo geral, o melhor entre os demais. Nas mesorregiões Noroeste, Norte Central e Norte Pioneiro, o rendimento alcançou valores da primeira classe, alta produtividade, acima de 84 ton/ha. Mesmo a mesorregião Sudoeste, que estava na última classe, produtividade muito baixa, passou para a terceira classe, 51 ton/ha a 62 ton/ha.

No ano de 2002 a produtividade (mesorregiões Noroeste, Norte Centro e Centro-Ocidental) foi rebaixada para segunda classe, valores entre 73 ton/ha e 84 ton/ha. Apenas a Norte Pioneiro continuou na primeira classe, ou seja, com valores acima de 84 ton/ha.

Em 2006 as mesorregiões Centro-Ocidental e Norte Pioneiro ocuparam a primeira classe, ficando a Norte Central, Noroeste, e Centro-Oriental na segunda classe de produtividade. Na sexta classe permaneceram a mesorregião Sudeste paranaense e a região Metropolitana de Curitiba.

Os valores de produtividade dos anos de 2000 e 2005 foram inseridos por desviar, de certa forma, da série temporal estudada. Quando comparados com os 
anos de 1998 e 2002, apresentaram notáveis reduções nos rendimentos. Em 2000 a mesorregião Norte Pioneiro foi a que apresentou os melhores rendimentos, ficando na segunda classe (73 ton/ha a 84 ton/ha). O cenário produtivo em 2005 foi semelhante ao de 2000. Nesse ano a maior classe produtiva foi a segunda, média alta, para as mesorregiões Norte Central e Centro-Ocidental. 


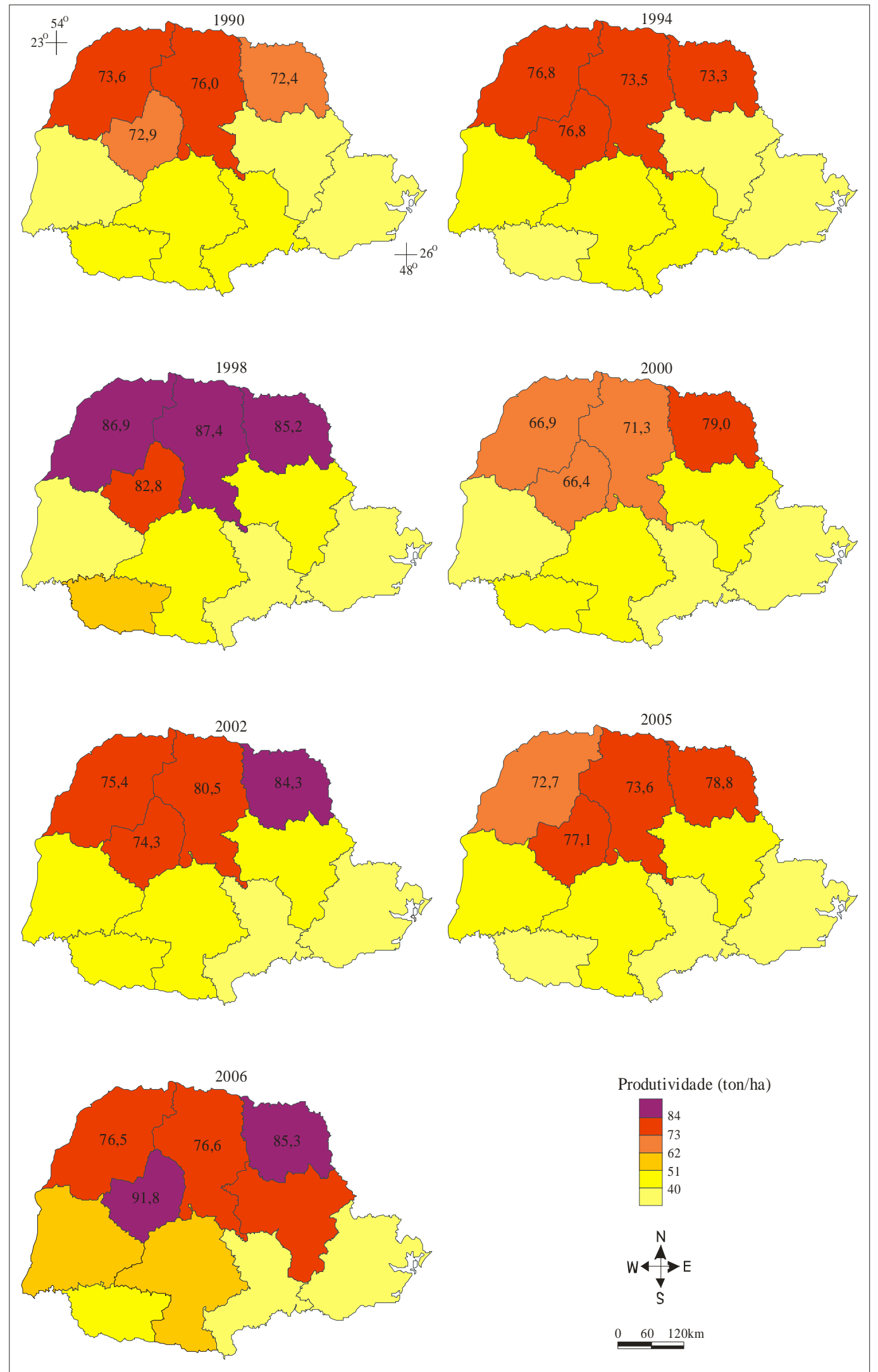

Figura 32 - Produtividade da cana-de-açúcar nas mesorregiões paranaenses, para os anos de 1990, 1994, 1998, 2000, 2002, 2005 e 2006. Org.: Domingues, I.A.S. (2008). 
4.5.2 - Mapeamento por microrregiões das variáveis área plantada, produção e produtividade

A evolução representada nos mapas, por período de quatro em quatro anos, ilustra que houve, a partir de 1994, aumento gradativo em área plantada, principalmente em 4 microrregiões (Umuarama, Cianorte, Paranavaí e Astorga), dentre as 18 selecionadas (Figura 33). Em 1994, dessas 4 microrregiões apenas a de Astorga apresentou área plantada pertencente à classe média (36 a 48 mil ha). No ano de 1998, além de Astorga, Cianorte também ficou na classe média, vindo em seguida Umuarama e Paranavaí, que se elevam para a classe média baixa (24 a 36 mil ha). Em 1998 Astorga, Cianorte e Paranavaí passaram para as classes alta (acima de $60 \mathrm{mil} \mathrm{ha),} \mathrm{média} \mathrm{e} \mathrm{média} \mathrm{alta,} \mathrm{respectivamente.} \mathrm{No} \mathrm{último} \mathrm{ano} \mathrm{da} \mathrm{série,}$ as microrregiões de Astorga, Cianorte e Paranavaí subiram para a classe alta e Umuarama para a classe média alta. 

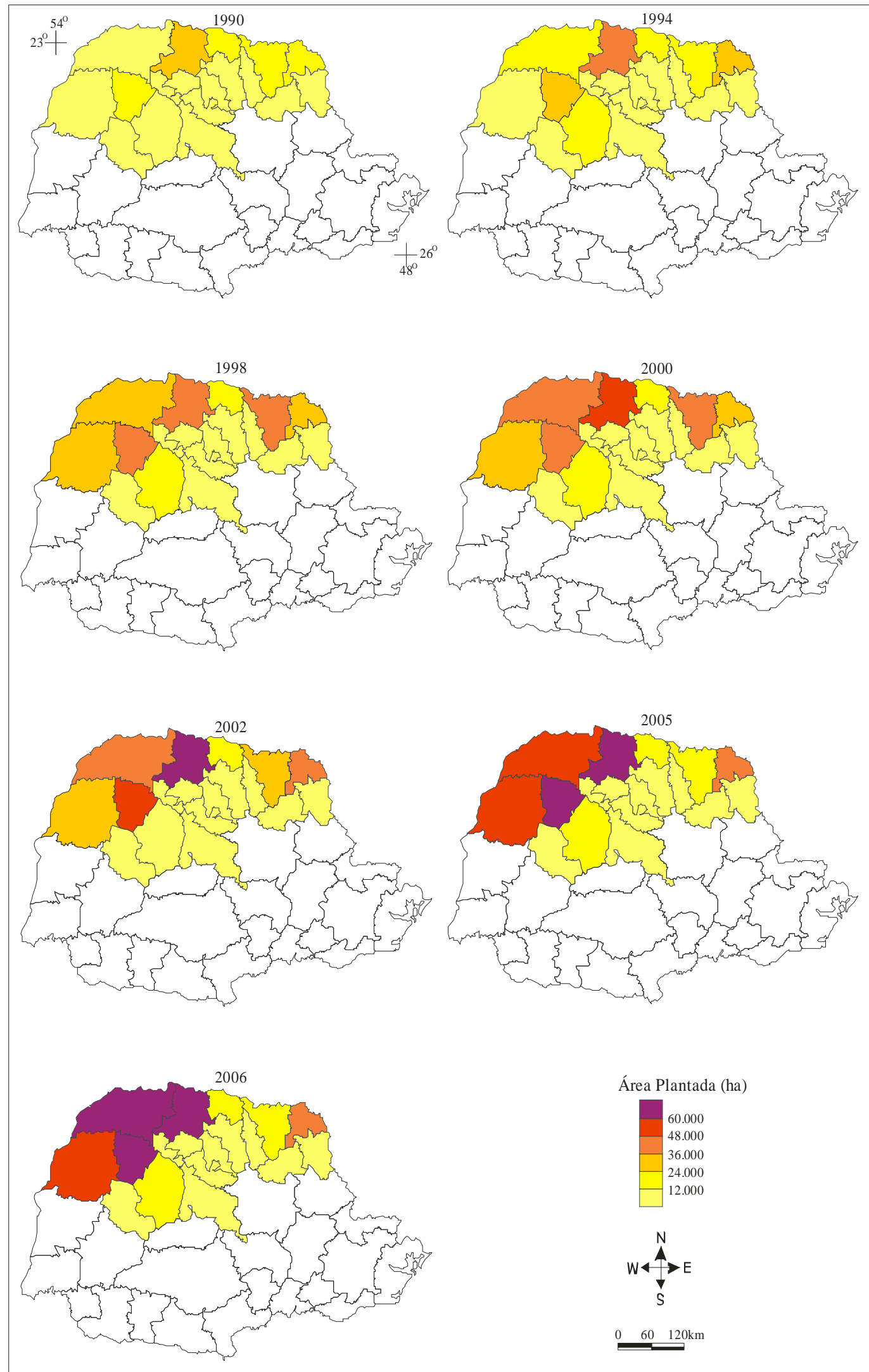

Figura 33 - Área plantada com cana-de-açúcar nas microrregiões paranaenses, para os anos de 1990, 1994, 1998, 2000, 2002, 2005 e 2006. Org.: Domingues, I.A.S. (2008). 
Dentro do período de quatro em quatro anos, de modo geral, a produção acompanhou o comportamento da área plantada (Figura 34). Com exceção do ano de 2000, que foi representado justamente para mostrar que, embora houvesse aumento em área plantada em algumas microrregiões, para esse ano houve redução na produção. Ficou demonstrado, dessa forma, que provavelmente deva ter ocorrido algum tipo de influência climática sobre a cultura. 


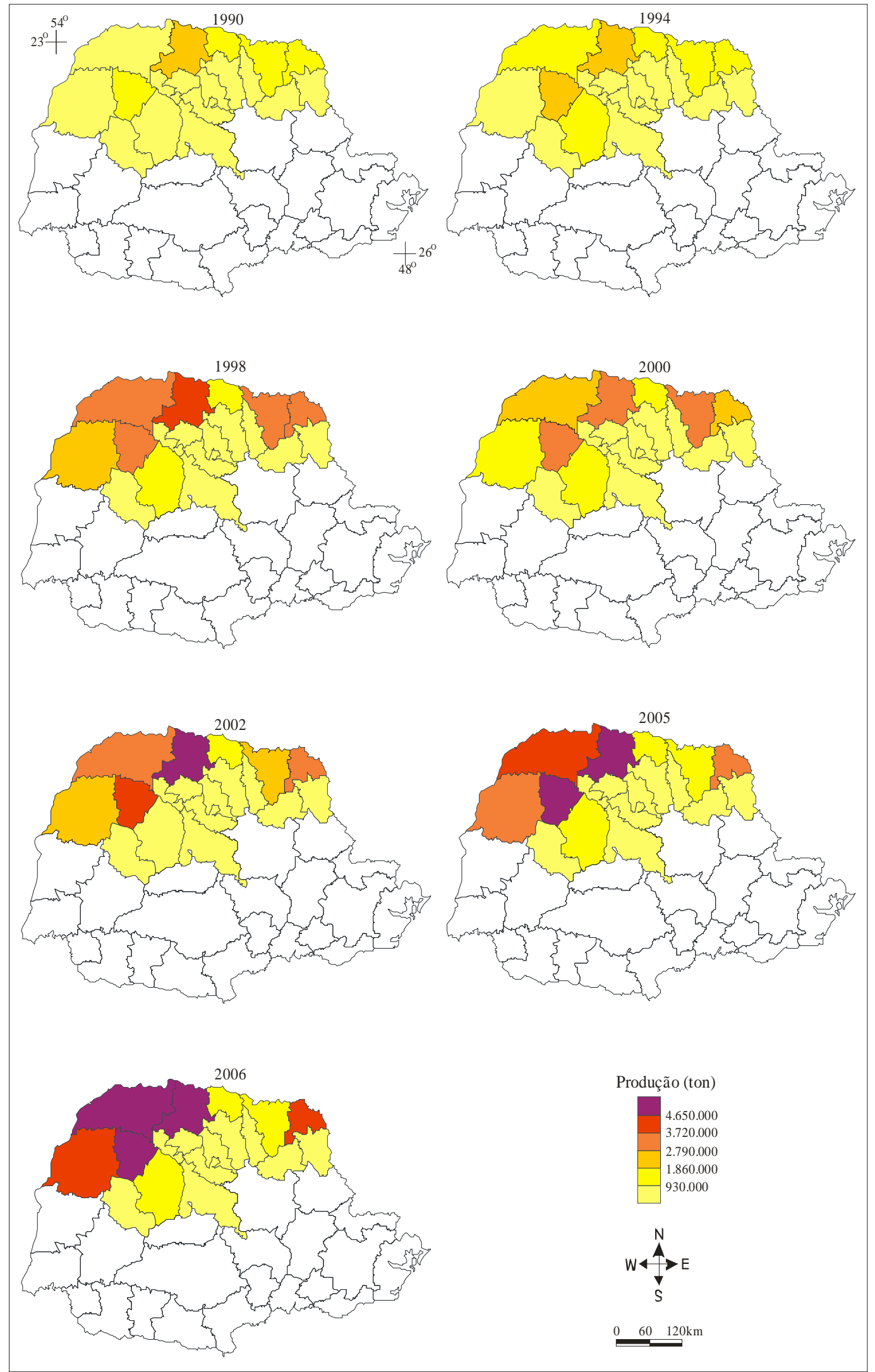

Figura 34 - Produção da cultura da cana-de-açúcar nas microrregiões paranaenses, para os anos de 1990, 1994, 1998, 2000, 2002, 2005 e 2006. Org.: Domingues, I.A.S. (2008). 
O mapeamento por intervalo de quatro em quatro anos do rendimento da cana-de-açúcar teve como destaque o ano de 1998, por apresentar os maiores índices (Figura 35). Nesse cenário tem-se como destaque a microrregião de Londrina na classe alta (acima de 99 ton/ha). As microrregiões de Paranavaí, Astorga, Maringá, Faxinal, Apucarana e Jacarezinho se enquadraram na classe média alta ( 88 a 99 ton/ha) e as demais nas classes média ( 77 ton/ha a 88 ton/ha) e média baixa (66 ton/ha a 77 ton/ha).

Em seguido a esse ano, tem-se o de 2006, com boa parte das microrregiões inseridas nas classes média alta, média e média baixa. Nos demais anos prevalecem as classes média, média baixa e baixa (55 ton/ha a 66 ton/ha). Os dois anos (2000 e 2005) inseridos tiveram por objetivo ilustrar que do ano de 1998 para os de 2000 e 2005 houve uma redução de até duas classes para a maioria das microrregiões. Cabe ainda salientar que o mesmo aconteceu com a produção do ano de 2000 , quando houve aumento da área plantada e redução na produção. 

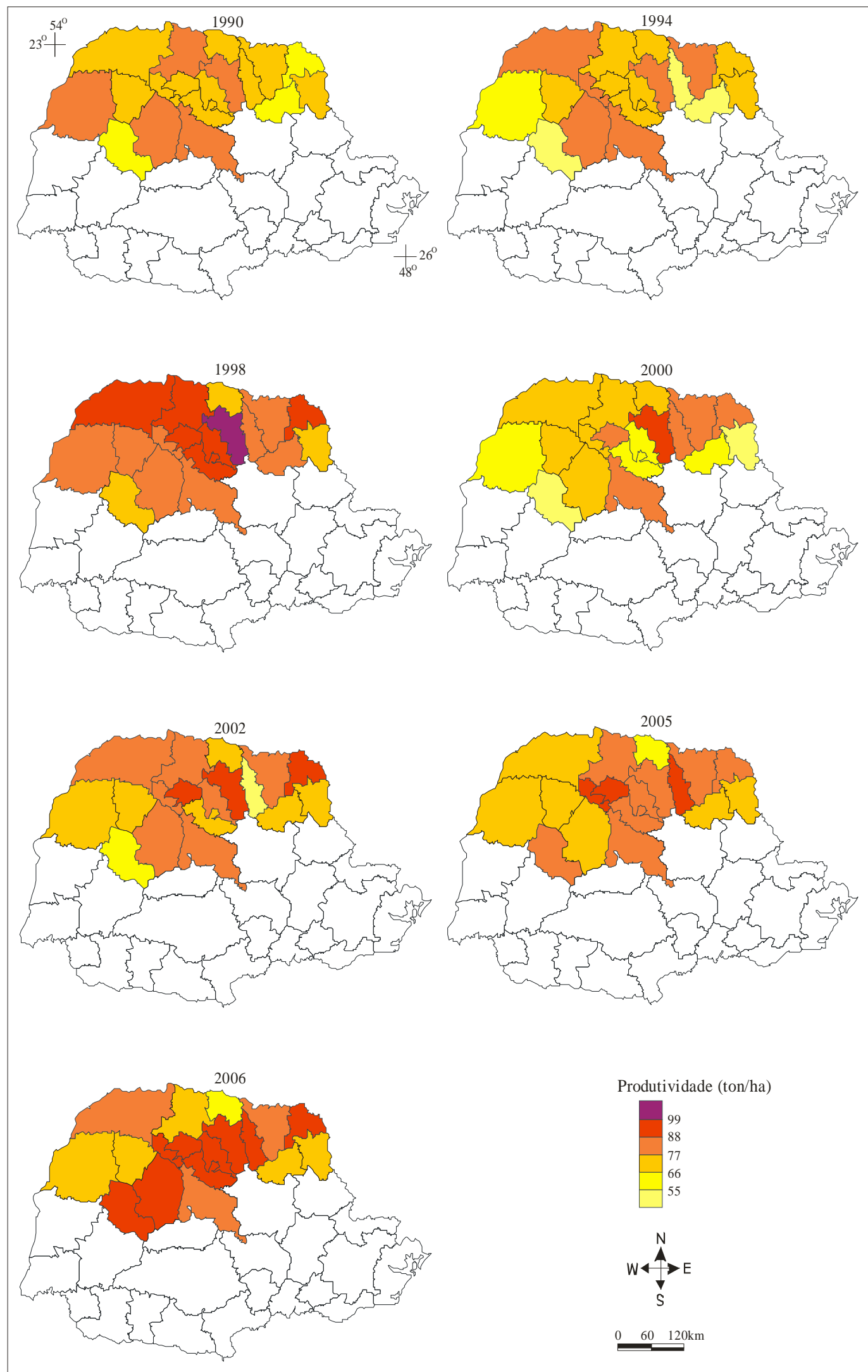

Figura 35 - Produtividade da cana-de-açúcar nas microrregiões paranaenses, para os anos de 1990, 1994, 1998, 2000, 2002, 2005 e 2006. Org.: Domingues, I.A.S. (2008). 
4.5.3 - Mapeamento da evolução espaço-temporal da cana-de-açúcar por municípios das variáveis área plantada, produção e produtividade

Dentre as escalas de mesorregião e microrregião foram selecionados 18 municípios mais representativos em termos de produtividade da cultura da cana-deaçúcar. Esses municípios tiveram produtividades do período acima de 71 ton/ha. Além dos dados de rendimentos, foi mapeada também a evolução de área plantada e de produção.

-Área plantada:

Para o início do período estudado, a área plantada com a cultura da cana-deaçúcar esteve na classe baixa (2.350ha a 4.700ha), com apenas um município na classe média baixa (4.700 a 7.050). A partir de 1994 houve uma mudança de área plantada para as classes mais elevadas em 6 municípios (Figura 36). Entre estes houve certa manutenção no tamanho da área a partir de 2000.

-Produção:

Quanto à produção, esta acompanhou, de modo geral, o comportamento evolutivo da área plantada (Figura 37). Em 1990 a maior produção pertencia ao município de Cambará, com valores inseridos na classe média baixa (400.000ton a 600.000ton). A partir de 1998 os 6 municípios com as maiores áreas plantadas também foram os que apresentaram as maiores produções, alcançando as três primeiras classes de valores (> 600.000ton e 1.000.000ton).

-Produtividade:

Os mapas da evolução espaço-temporal da produtividade dos 18 municípios apresentaram variações de quedas ou aumentos de rendimentos principalmente nos anos de 1998, 2000 e 2006 (Figura 38). Em 1998 houve mudança para classes mais elevadas, em até duas posições, basicamente nos municípios da mesorregião Norte Central. 
Esses municípios, que no ano de 1994 estavam na classe média, passaram para as classes alta e muito alta (acima de 95 ton/ha). No ano de 2006 a classe de valores predominante para a maioria dos municípios foi a média, com valores entre 80 ton/ha a 95 ton/ha.

O ano de 2000, quando comparado, principalmente, com o ano de 1998, teve mudança de até três classes inferiores, como é o caso do município de Mandaguari, que estava na classe muito alta e passou para a classe baixa, seguido do município de Pitangueiras, que estava na classe alta e passou para a classe muito baixa. 


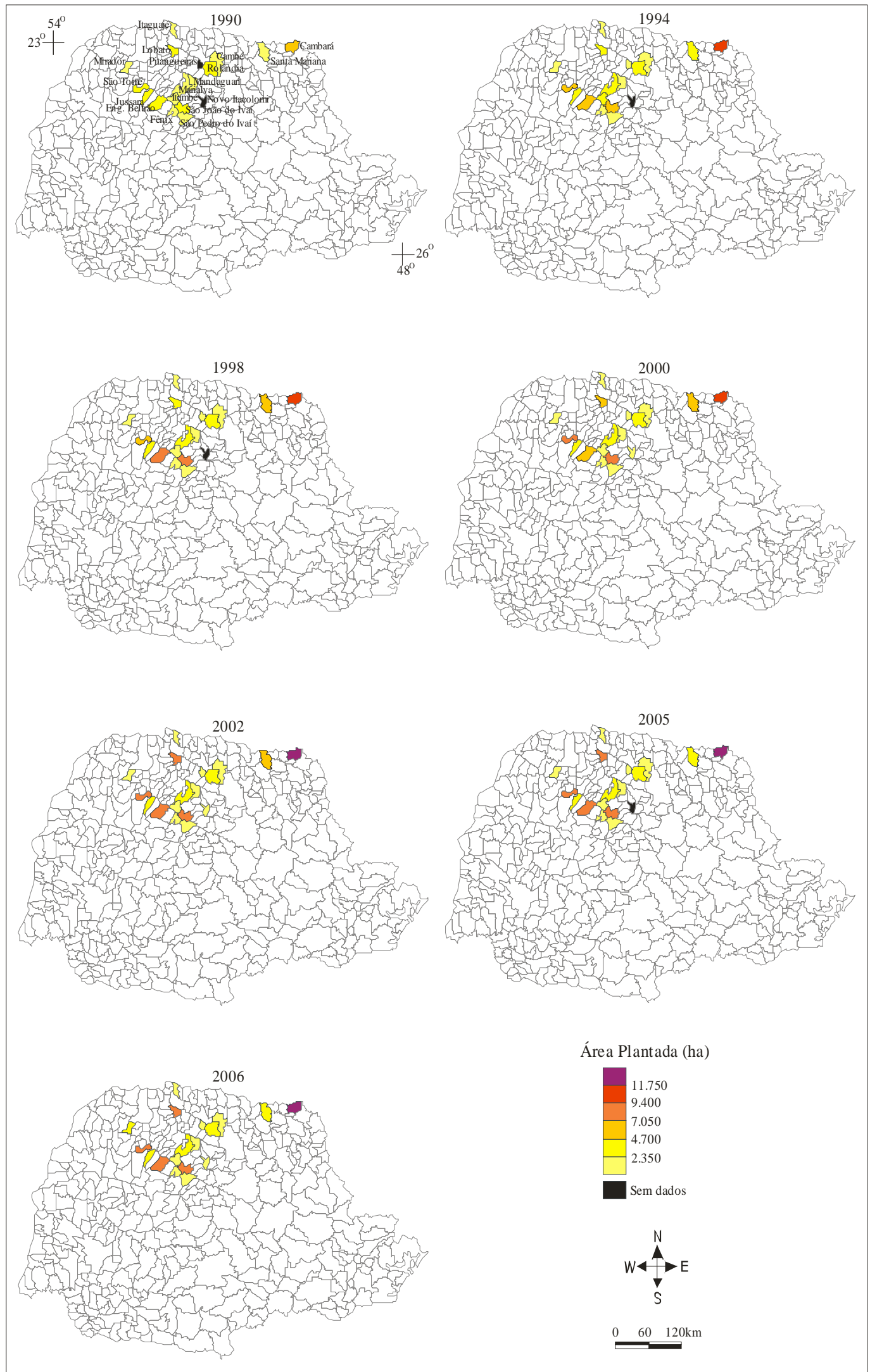

Figura 36 - Área plantada com cana-de-açúcar nos principais municípios produtores do Paraná, período 1990, 1994, 1998, 2000, 2002, 2005 e 2006. Org.: Domingues, I.A.S. (2008). 

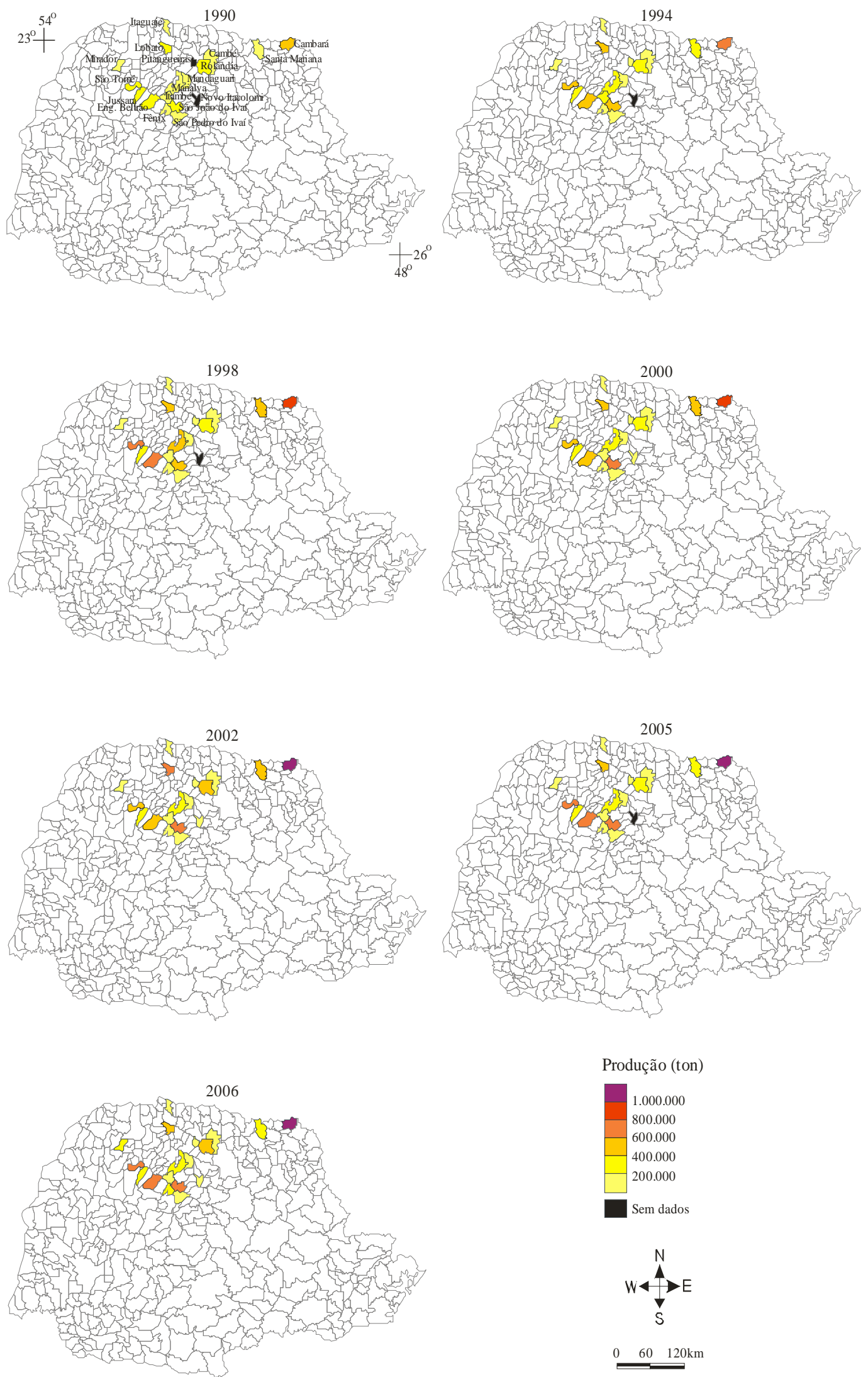

Figura 37 - Produção da cana-de-açúcar nos principais municípios produtores do Paraná, período 1990, 1994, 1998, 2000, 2002, 2005 e 2006. Org.: Domingues, I.A.S. (2008). 


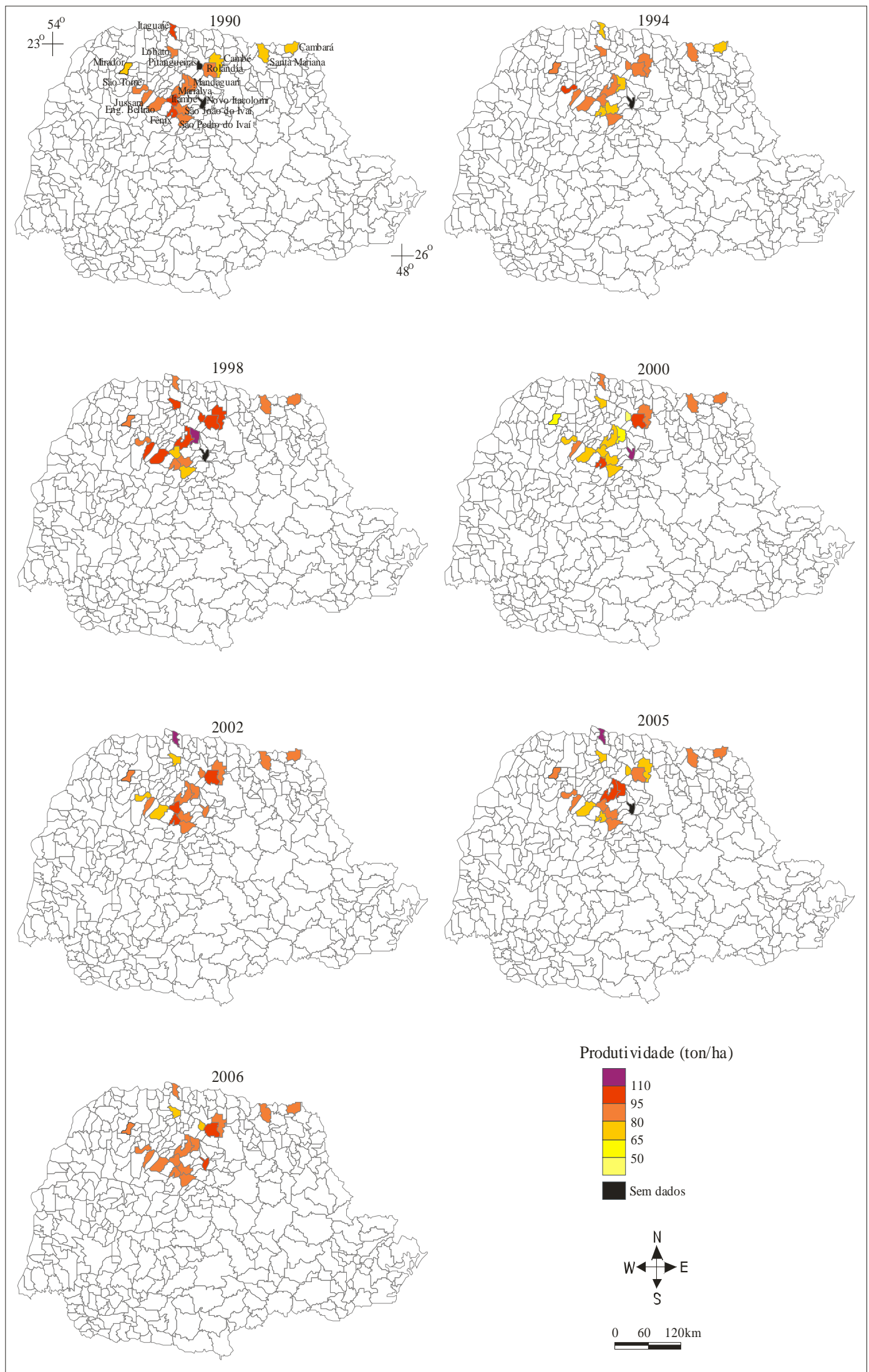

Figura 38 - Produtividade da cana-de-açúcar nos principais municípios produtores do Paraná, anos de 1990, 1994, 1998, 2000, 2002, 2005 e 2006. Org.: Domingues, I.A.S. (2008). 


\section{6 - Variabilidade termopluviométrica a nível local}

\subsection{1 - Pluviometria}

De acordo com a série temporal pluviométrica considerada (1976 a 2006) neste estudo para essas duas localidades, tem-se o seguinte (Figuras 39): a média anual da precipitação foi de $1.604 \mathrm{~mm}$ (Cambé) e de $1.485 \mathrm{~mm}$ (Mirador). Segundo Nagarolli (2007), o Norte desse estado apresentou total de precipitação média entre $1.500 \mathrm{~mm}$ e $1.600 \mathrm{~mm}$ ao ano.

Os anos de 1980 (2.123mm), 1983 (2.130mm) e 1996 (2.138mm) apresentaram os totais de chuvas mais elevados em Cambe, e os anos de 1976 $(1.947 \mathrm{~mm}), 1983(1.981 \mathrm{~mm})$ e $1997(2.112 \mathrm{~mm})$ em Mirador. As mais reduzidas precipitações, entre $1.153 \mathrm{~mm}$ e $1.290 \mathrm{~mm}$, ocorreram nos anos de 1970, 1984, 1985 (1.153 mm), 1999 (1.290mm), 2003 e 2006 em Cambe, e em Mirador os totais mais reduzidos ocorreram nos anos de $1978(1.043 \mathrm{~mm})$ e $1985(977 \mathrm{~mm})$. O município de Cambé teve 18 anos com chuvas acima da média anual e em Mirador registraram-se 14 anos.

Quanto à variação mensal da pluviometria (Figura 39 A1 e B1), em dezembro, janeiro e fevereiro registraram-se os mais elevados totais, e em julho e agosto os mais reduzidos. Em Cambé os totais foram acima de $200 \mathrm{~mm}$ em dezembro e janeiro e $60 \mathrm{~mm}$ em julho e agosto. Em Mirador os totais ficaram em torno de $193 \mathrm{~mm}$ em janeiro, $169 \mathrm{~mm}$ em dezembro, $57 \mathrm{~mm}$ em julho e $54 \mathrm{~mm}$ em agosto, respectivamente. Caviglione et al. (1997), estudando as condições pluviométricas do Paraná, identificaram, nas regiões Norte e Noroeste, que o trimestre mais chuvoso foi o de dezembro a fevereiro e o mais seco de junho a agosto.

A frequência da precipitação revelou que em dezembro, janeiro e fevereiro ocorreu maior número de dias com chuva; o mesmo período foi observado para os maiores totais de chuva. Em julho e agosto foram menos dias com chuva, os quais apresentaram também os totais mais reduzidos. 
Em Cambé choveu em média 15 dias no mês de dezembro e janeiro, e em julho e agosto em torno de 6 dias (Figura 40 C). Para o mesmo período, em Mirador os números de dias foram de 13 e 14 e 5,8 e 5,5 respectivamente (Figura 40 D).

Os anos com mais dias com chuva foram os de 1983 e 1997, comuns aos 2 municípios. O número de dias com chuva foi de 156 e 150 em Cambé e de 145 e 133 em Mirador. Os anos com menor número de dias com chuva foram os de 1978 (97 dias), 1985 (94 dias) e 1999 (98 dias) em Cambe, e em Mirador os anos de 1978 (86 dias), 1991 (94 dias) e 1999 (95 dias), (Figura 40 A e B).

Dentro desse período de 31 anos, o número de dias com chuvas de intensidades acima de $50 \mathrm{~mm}$ ocorreu nos meses de dezembro a março em Cambé, e em janeiro e maio no município de Mirador (Figura 40 A1 e D). Em Cambé, os anos com maior número de dias com chuva acima de $50 \mathrm{~mm}$ foram os de 1980, 1987 e 1995, com 9 dias cada um, sendo a média do período de 5,5 dias (Figura 40 A). Para Mirador os anos foram os de 1980 e 1990, também com 9 dias cada um, com média do período de 4,5 dias (Figura 40 B). É interessante destacar, por exemplo, o ano de 1977 nos dois municípios. O mês de dezembro em Cambé teve 15 dias com chuvas, alcançando um total de $283,7 \mathrm{~mm}$; desses, 2 dias foram de chuvas acima de $50 \mathrm{~mm}$. No dia 20/12/77 choveu $71,7 \mathrm{~mm}$ e no dia $22 / 12 / 77,62,4 \mathrm{~mm}$, ou seja, apenas $134,1 \mathrm{~mm}$ foram distribuídos ao longo de 13 dias com intensidades inferiores a $50 \mathrm{~mm}$. Para o mesmo ano, em Mirador, no mês de junho choveu 154,5mm; desses, $69,4 \mathrm{~mm}$ no dia 16/06, e em setembro choveu $77,7 \mathrm{~mm}$ em 6 dias; desse total, $54,2 \mathrm{~mm}$ da precipitação ocorreu em apenas um dia, 17/10.

Para o período dos anos considerados neste estudo (1981 a 2006), foram observadas também chuvas com totais elevados em um curto período de tempo, as chuvas acima de $50 \mathrm{~mm}$, ou seja, as chuvas concentradas, que tendem a um maior escoamento superficial. Sendo essa água não infiltrada no solo, deixa de ser contabilizada, podendo aumentar o déficit hídrico. Dessa forma, pode influenciar negativamente no desenvolvimento vegetativo da cultura da cana-de-açúcar ou positivamente no seu estádio de maturação, refletindo na produtividade. 

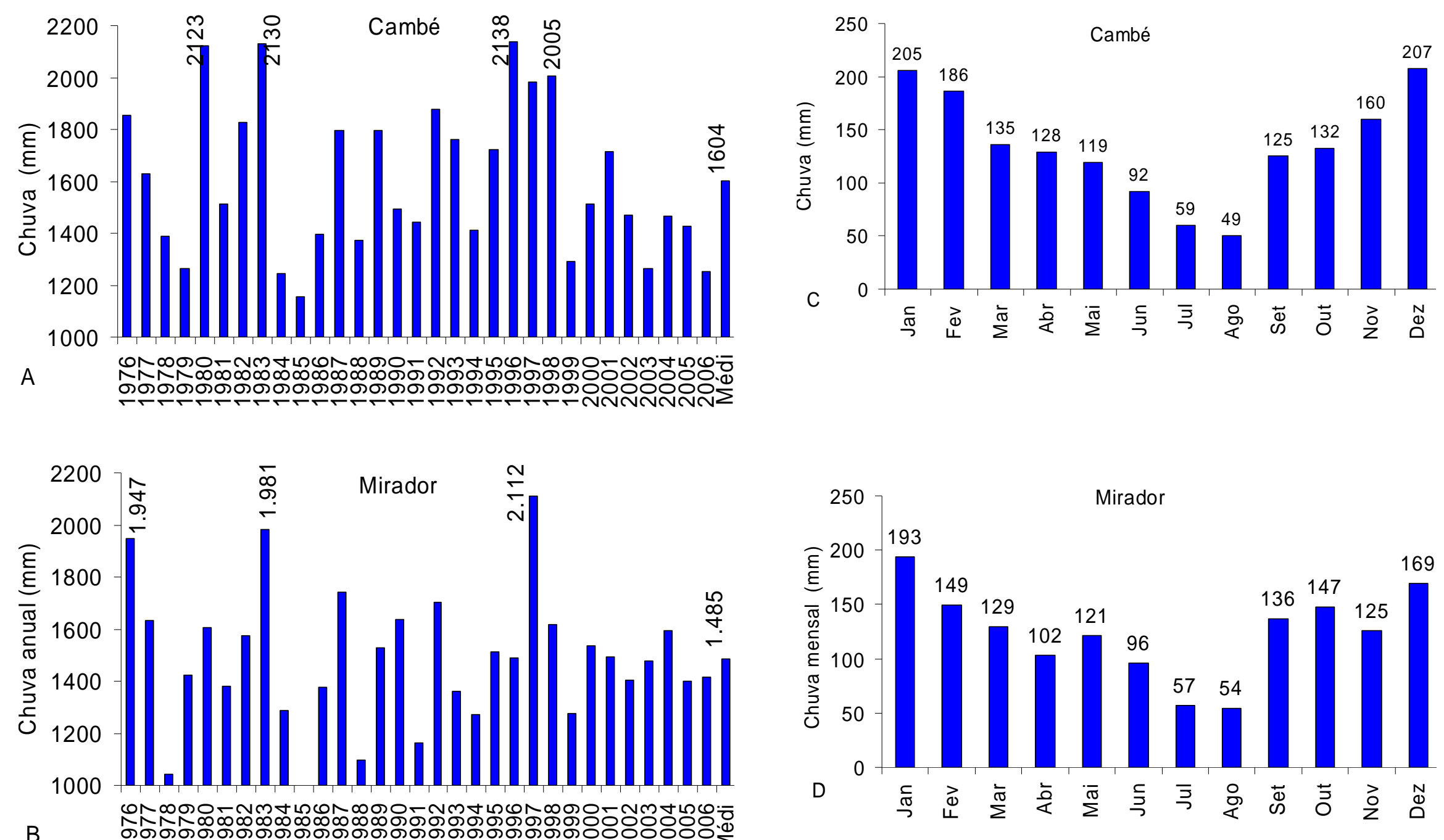

Figura 39 - Precipitação pluvial total anual em Cambe (A) e em Mirador (B) e precipitação pluviométrica mensal em Cambé (C) e em Mirador (D), para o período de 1976 a 2006. Org.: Domingues, I.A.S. (2008). 

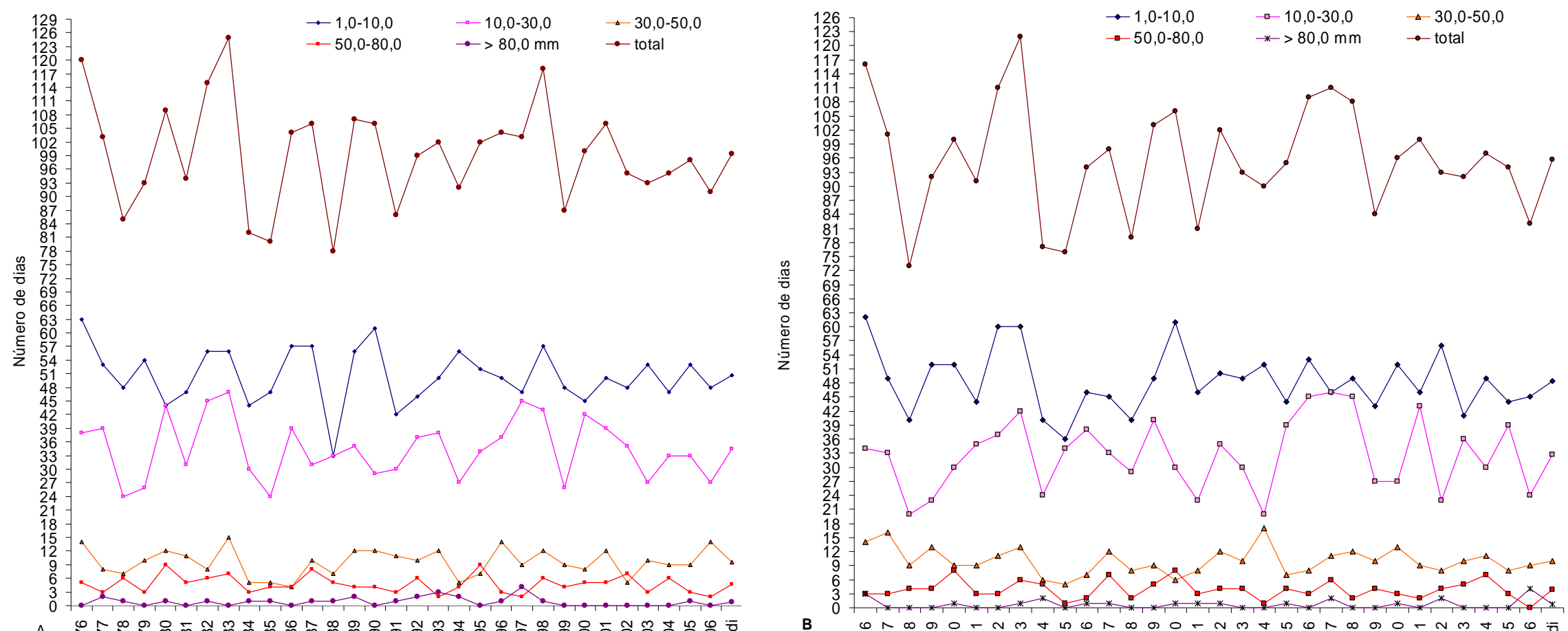

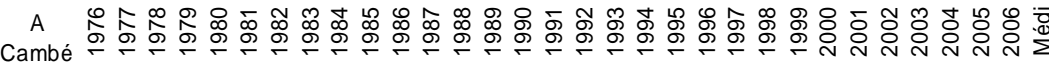

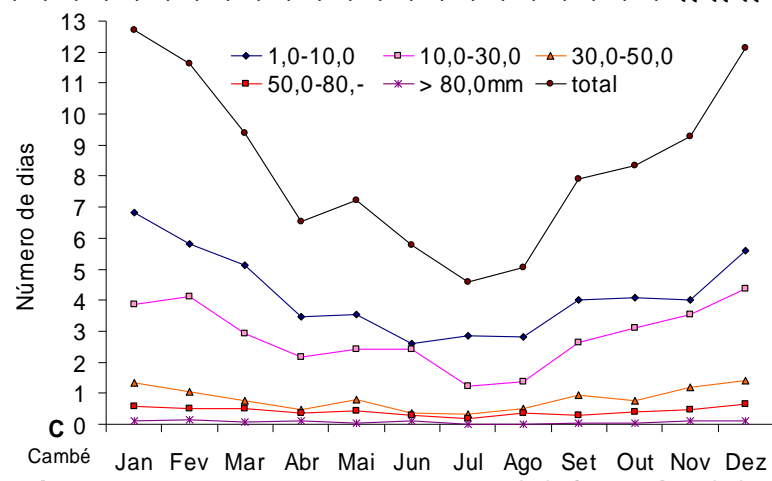

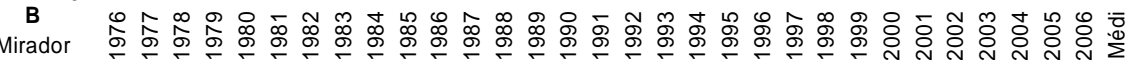

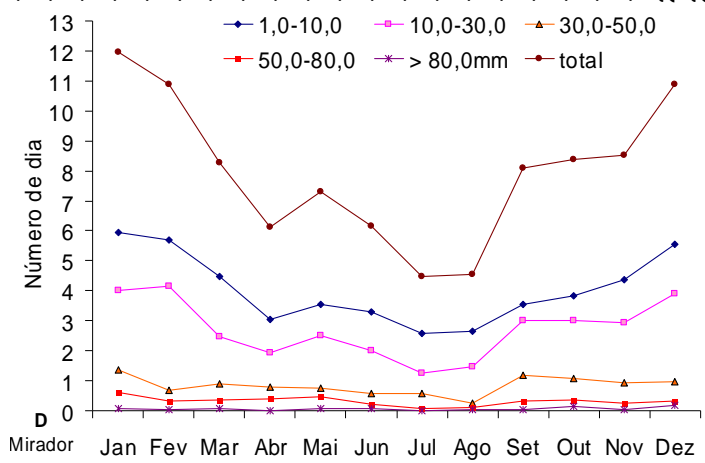

Figura 40 - Número de dias com chuva anual, (A) Cambé e (B) Mirador, e mensal (C) Cambé e (D) Mirador, período de 1976 a 2006. Org.: Domingues, I.A.S. (2008). 
A evolução temporal e a quantificação desse tipo de chuva, ocorrida nos municípios de Cambé e Mirador, foram analisadas (Tabela 17 e 18).

Tabela 17 - Ocorrência de chuvas acima de 50mm para o período de 1981 a 2006 em Cambé PR.

\begin{tabular}{|c|c|c|c|c|c|c|c|}
\hline \multirow[t]{2}{*}{ Dia } & \multirow[t]{2}{*}{ Mês } & \multirow[t]{2}{*}{ Ano } & \multirow{2}{*}{$\begin{array}{l}\text { №. dias com } \\
\text { chuva no mês }\end{array}$} & \multirow{2}{*}{$\begin{array}{c}\text { Chuva } \\
\text { diária }(\mathrm{mm})\end{array}$} & \multirow{2}{*}{$\begin{array}{l}\text { Total chuva } \\
\text { mensal (mm) }\end{array}$} & \multicolumn{2}{|c|}{ Porcentagem } \\
\hline & & & & & & Chuva mensal & Chuva anual \\
\hline 13 & 2 & 1981 & 11 & 50 & 50 & 32.18 & \multirow{4}{*}{14,56} \\
\hline 28 & 4 & 1981 & 7 & 52.6 & 52.6 & 36.45 & \\
\hline 16 & 6 & 1981 & 6 & 52 & 52 & 46.22 & \\
\hline 5 & 10 & 1981 & 10 & 65,9 & 65.9 & 25,05 & \\
\hline 12 & 6 & 1982 & 13 & 102 & 102 & 39.74 & \multirow{7}{*}{25.14} \\
\hline 9 & 7 & 1982 & 8 & 50,8 & 50,8 & 32.77 & \\
\hline 6 & 11 & 1982 & \multirow{3}{*}{17} & 69 & 123,3 & 38,16 & \\
\hline 9 & 11 & 1982 & & 54.3 & & & \\
\hline 21 & 11 & 1982 & & 55,6 & & & \\
\hline 12 & 12 & 1982 & \multirow[t]{2}{*}{17} & 50.4 & 127.8 & 35.63 & \\
\hline 22 & 12 & 1982 & & 77.4 & & & \\
\hline 17 & $\frac{1}{1}$ & 1983 & 16 & 64.4 & 64,4 & 27.01 & \multirow{7}{*}{20,58} \\
\hline 3 & 3 & 1983 & \multirow[t]{2}{*}{11} & 66 & 128,4 & 44,03 & \\
\hline 6 & 3 & 1983 & & 62,4 & & & \\
\hline 30 & 5 & 1983 & 15 & 59,6 & 59,6 & 19,30 & \\
\hline 6 & $\frac{6}{6}$ & 1983 & 14 & 74,8 & 124,8 & 47,91 & \\
\hline 7 & 6 & 1983 & & 50 & & & \\
\hline 18 & 9 & 1983 & 13 & 61,2 & 61,2 & 22,08 & \\
\hline 30 & 1 & 1984 & 11 & 55 & 55 & 43.96 & \\
\hline 14 & 4 & 1984 & 7 & 151,2 & 151,2 & 70,92 & \\
\hline 27 & 9 & 1984 & 5 & 58,4 & 58,4 & 41,45 & 25,33 \\
\hline 2 & 12 & 1984 & 14 & 51 & 51 & 19,69 & \\
\hline 16 & 3 & 1985 & 16 & 50,4 & 50.4 & 30,94 & \\
\hline 6 & 4 & 1985 & 10 & 98,2 & 98,2 & 36,81 & \\
\hline 21 & 5 & 1985 & 6 & 54.6 & 112,4 & 78,33 & 27,23 \\
\hline 22 & 5 & 1985 & & 57.8 & & & \\
\hline 2 & 11 & 1985 & 7 & 53,1 & 53,1 & 34,15 & \\
\hline 21 & 4 & 1986 & 5 & 53,6 & 53,6 & 54,09 & \\
\hline 15 & 8 & 1986 & & 62,5 & 62,5 & 40,80 & \\
\hline 19 & 10 & 1986 & 5 & 54 & 54 & 55,56 & \\
\hline 13 & 12 & 1986 & 16 & 58.9 & 58.9 & 61.04 & 16.39 \\
\hline 26 & 1 & 1987 & 15 & 53 & 107,6 & 51,07 & \\
\hline 27 & 1 & 1987 & & 54,6 & & & \\
\hline 20 & 2 & 1987 & 16 & 59.9 & 59.9 & 29.62 & \\
\hline 23 & 6 & 1987 & 6 & 58,1 & 58,1 & 38,60 & \\
\hline 6 & 11 & 1987 & & 61 & 277,3 & 79,91 & 30.93 \\
\hline 7 & 11 & 1987 & 8 & 83,2 & & & \\
\hline 14 & 11 & 1987 & & 57,8 & & & \\
\hline 15 & 11 & 1987 & & 75.3 & & & \\
\hline 18 & 12 & 1987 & 9 & 52.8 & 52,8 & 33,98 & \\
\hline 17 & 1 & 1988 & 10 & 53.6 & 53,6 & 26.07 & \\
\hline 8 & 2 & 1988 & 7 & 52 & 52 & 45.45 & \\
\hline 2 & 3 & 1988 & 5 & 56.5 & 139.5 & 77.46 & \\
\hline 3 & 3 & 1988 & & $\frac{0.0}{83}$ & & & 25,86 \\
\hline 26 & 4 & 1988 & 11 & 58,2 & 58,2 & 31,65 & \\
\hline 30 & 5 & 1988 & 13 & 51,4 & 51,4 & 20,84 & \\
\hline 15 & 1 & 1989 & 21 & 50 & 50 & 14,43 & \\
\hline 11 & 6 & 1989 & 7 & 57.5 & 57.5 & $\begin{array}{l}14,40 \\
49,06\end{array}$ & \\
\hline 27 & 1 & 2003 & 18 & 73,8 & 73,8 & 25,71 & \\
\hline 20 & 4 & 2003 & 6 & 68 & 68 & 55.51 & 15.6 \\
\hline 8 & 7 & 2003 & 4 & 55,5 & 55,5 & 66,23 & \\
\hline 11 & 1 & 2004 & 11 & 58.4 & 125,7 & 83,19 & \\
\hline 25 & 1 & 2004 & & 67,3 & & & \\
\hline 25 & 5 & 2004 & 17 & 68,8 & 68,8 & 27,98 & 25,47 \\
\hline 19 & 10 & 2004 & 10 & 62,8 & 118,1 & 47,79 & \\
\hline 24 & 10 & 2004 & & 55.3 & & & \\
\hline 11 & 11 & 2004 & 10 & 60,8 & 60,8 & 47,87 & \\
\hline 17 & 1 & 2005 & 22 & 84.2 & 136.8 & 33,48 & \\
\hline 20 & 1 & 2005 & & 52.6 & & & 18,61 \\
\hline 25 & 5 & 2005 & 6 & 65 & 65 & 72,95 & \\
\hline 6 & 10 & 2005 & 18 & 63.5 & 63.5 & 24.27 & \\
\hline 23 & 1 & 2006 & 13 & 51.8 & 51.8 & 42.77 & 8.84 \\
\hline 2 & 9 & 2006 & 10 & 59 & 59 & 37.18 & \\
\hline
\end{tabular}

Org.: Domingues, I.A.S. (2008). 
No município de Cambé esse tipo de chuva teve a seguinte representatividade (Tabela 17$)$ :

O maior total de dias com chuvas acima de $50 \mathrm{~mm}$ foi 9 (1995), distribuído em sete meses, e o menor foi de dois dias (1997). Quanto ao percentual mensal, o maior foi de $81 \%$ no mês de julho de 1990, seguido de $79 \%$ em 1987 e de $78 \%$ em 1985, e o menor em janeiro de 1989, com 14,4\%, seguido de 2002 , com $15,6 \%$. O maior percentual anual ocorreu no ano de 1992, com 35,2\%, e o menor em 1990, com $13,4 \%$.

Uma análise anual apontou como destaque:

No ano de 1981, a maioria dos dias teve chuva nessa intensidade acima de $30 \%$ do total mensal. Em 1982 para os seis dias distribuídos em quatro meses, essas chuvas representaram $25 \%$ do total anual, tendo no dia 12 de junho chovido $40 \%$ do total mensal.

No ano de 1983, houve sete dias de chuva em seis meses, somando um total que representou $21 \%$ do total anual. Para o ano de 1984 a chuva foi de $25 \%$ do total anual, distribuída em quatro dias, e cada dia em meses diferentes; apenas no dia $14 / 04$ a chuva ocorrida foi de $71 \%$ da mensal.

Em 1985, a chuva se deu em cinco dias, distribuídos em quatro meses; desses, 78\% da mensal ocorreram nos dias 21 e 22/05. Em 1986 a chuva representou $16 \%$ da anual, distribuída em quatro dias durante quatro meses.

No ano de 1987, houve sete dias com chuva dessa intensidade, sendo que nos dias 7 e $14 / 11$ o total precipitado esteve entre $75 \mathrm{~mm}$ e $85 \mathrm{~mm}$. O total de todos esses dias representou $31 \%$ do total anual.

Em 1988, as chuvas acima de 50mm aconteceram em seis dias, distribuídos em cinco meses, totalizando $26 \%$ do total anual. Dos totais mensais, as chuvas foram em torno de $77 \%$ a 26\%. Em 1989 houve seis dias com chuvas, distribuídos em quatro meses, representando $24 \%$ do total anual. Nos dias 29/12 e 30/12 a precipitação foi de $95 \mathrm{~mm}$ e $117 \mathrm{~mm}$, respectivamente. 
Em 1990, no mês de julho choveu $181,7 \mathrm{~mm}$, distribuídos em 13 dias; dentre estes, nos dias 16 e 17 a precipitação foi de $81 \%$ (147,5mm) de toda a chuva desse mês.

Em 1995, nos meses de março, abril, julho e dezembro, nos dias 1, 10, 20 e 27 , ocorreram chuvas de $55 \%$ a $75 \%$, correspondentes ao total de cada mês. As chuvas dos dias $01 / 04$ e 10/07 corresponderam a $60 \%$ e $70 \%$ do total mensal.

No ano de 1997, o destaque foi para o mês de junho, quando em apenas um dia choveu o equivalente a $50 \%$ do total desse mês. O mês de maio de 1998 teve uma situação semelhante em apenas um dia (28/09). Em 1999, no dia 16/04 choveu $78,8 \mathrm{~mm}$ e durante esse mês o total de chuva foi de $94,4 \mathrm{~mm}$. Da mesma, forma no mês de maio, no dia $07 / 05$ choveu $71,8 \mathrm{~mm}$ de um total de $102,2 \mathrm{~mm}$. No mês de março de 2000, as precipitações ocorridas nos dias 05 e 17/03 corresponderam cada uma a $56 \%$ do total do mês $(230,0 \mathrm{~mm})$. A chuva do dia 22/07/2002 representou um percentual de $66 \%$ do total mensal de $77,8 \mathrm{~mm}$. No ano de 2003 , as chuvas ocorridas nos dias 20/04 e 08/07 foram de $56 \%$ e $66 \%$ do total, $122,5 \mathrm{~mm}$ e $83,8 \mathrm{~mm}$, respectivamente, e a precipitação de $65,5 \mathrm{~mm}$ ocorrida no dia 25/05/2005 correspondeu a $73 \%$ do total mensal.

No município de Mirador a distribuição pluvial acima de $50 \mathrm{~mm}$, para o período considerado, teve os seguintes anos com os maiores totais de chuva (Tabela 18):

O maior total de dias com chuvas acima de $50 \mathrm{~mm}$ foi 9 (1990), distribuídos em cinco meses, e o menor foi de um dia (1985 e 1994). Quanto ao percentual mensal, o maior foi de $81 \%$ no mês de maio de 1980 e abril de 1982, seguido de $80 \%$ em 1999 e de $74 \%$ em 1990 , e o menor em maio de 1992 , com $15,1 \%$, seguido de 1996, com 19,9\%. A maior quantidade de chuvas em relação ao total anual ocorreu no ano de 1984 , com $39,2 \%$, seguida de 1990 , com $35,2 \%$, e as menores quantidades foram em 1985 com $5,6 \%$ e 1998 com $8,6 \%$.

Quanto à análise anual, observou-se como destaque:

Nos anos de 1981 e 1982, houve quatro dias com chuvas dessa intensidade, distribuídos em três meses. Essas chuvas representaram 12,1\% e 12,5\% do total anual respectivamente, embora para o ano de 1982 ocorressem dois dias com chuvas que totalizaram $61 \%$ e $81 \%$ do total mensal. 
Tabela 18 - Precipitação pluviométrica acima de 50mm para o período de 1990 a 2006 em Mirador.

\begin{tabular}{|c|c|c|c|c|c|c|c|}
\hline \multirow[t]{2}{*}{ Dia } & \multirow[t]{2}{*}{ Mês } & \multirow[t]{2}{*}{ Ano } & \multirow{2}{*}{$\begin{array}{l}\text { №. dias com } \\
\text { chuva (mês) }\end{array}$} & \multirow{2}{*}{$\begin{array}{l}\text { Chuva diária } \\
(\mathrm{mm})\end{array}$} & \multirow{2}{*}{$\begin{array}{l}\text { Total chuva mensal } \\
(\mathrm{mm})\end{array}$} & \multicolumn{2}{|c|}{ Porcentagem } \\
\hline & & & & & & Chuva mensal & Chuva anual \\
\hline 9 & 1 & 1981 & 12 & 58,6 & 58,6 & 35,34 & \multirow[b]{3}{*}{12.15} \\
\hline 27 & 4 & 1981 & 8 & 58,1 & 58,1 & 44,15 & \\
\hline 7 & 12 & 1981 & 17 & 51,3 & 51,3 & 22,29 & \\
\hline 22 & 3 & 1982 & 7 & 78,7 & 78,7 & 61,06 & \multirow{3}{*}{12,54} \\
\hline 13 & 4 & 1982 & 4 & 55,8 & 55,8 & 81,34 & \\
\hline 12 & 6 & 1982 & 11 & 63,2 & 63,2 & 27,79 & \\
\hline 9 & 1 & 1983 & \multirow[t]{2}{*}{13} & 50,8 & \multirow[t]{2}{*}{118,4} & 52,20 & \multirow{7}{*}{22,88} \\
\hline 31 & 1 & 1983 & & 67,6 & & & \\
\hline 3 & 3 & 1983 & 9 & 57,2 & 130,2 & 48,75 & \\
\hline 5 & 3 & 1983 & & 73 & & & \\
\hline 31 & 5 & 1983 & 12 & 52,4 & 52,4 & 24,14 & \\
\hline 6 & 6 & 1983 & 15 & 85.4 & 85.4 & 28.41 & \\
\hline 22 & 11 & 1983 & 8 & 66,8 & 66,8 & 38,86 & \\
\hline 8 & 1 & 1984 & 9 & 63,2 & 63,2 & 37,49 & \\
\hline 14 & 4 & 1984 & 6 & 73 & 73 & 59,64 & \\
\hline 20 & 9 & 1984 & 7 & 95 & 95 & 57,93 & \\
\hline 1 & 11 & 1984 & 8 & 58,4 & 58,4 & 34,87 & 39,24 \\
\hline 2 & 12 & 1984 & & 51 & 214.9 & 60.54 & \\
\hline 7 & 12 & 1984 & 12 & 98.5 & & & \\
\hline 31 & 12 & 1984 & & 65.4 & & & \\
\hline 8 & 1 & 1985 & 6 & 55,2 & 55,2 & 65,48 & 5,65 \\
\hline 11 & 3 & 1986 & 7 & 55,2 & 55.2 & 36.17 & \\
\hline 13 & 5 & 1986 & 12 & 68,6 & 68,6 & 41,23 & 16,29 \\
\hline 19 & 12 & 1986 & 14 & 100,2 & 100,2 & 57,00 & \\
\hline 24 & 1 & 1987 & 13 & 52,9 & 52.9 & 29,08 & \\
\hline 30 & 4 & 1987 & 5 & 71,8 & 71,8 & 43,62 & \\
\hline 15 & 5 & 1987 & 11 & 59.2 & 59.2 & 23.10 & \\
\hline 15 & 6 & 1987 & 7 & 59 & 59 & 46,06 & \\
\hline 12 & 7 & 1987 & 5 & 55,6 & 55,6 & 43,99 & 28,36 \\
\hline 19 & 10 & 1987 & 9 & 81,4 & 81,4 & 48,39 & \\
\hline 7 & 11 & 1987 & 8 & 54,8 & 54,8 & 25,93 & \\
\hline 18 & 12 & 1987 & 8 & 59,4 & 59,4 & 35,55 & \\
\hline 16 & 1 & 1988 & 7 & 52,4 & 52,4 & 36,80 & \\
\hline 23 & 10 & 1988 & 10 & 68,6 & 68.6 & 29.57 & 11,05 \\
\hline 9 & 2 & 1989 & 9 & 50.8 & 50.8 & 29.06 & \\
\hline 11 & 6 & 1989 & 7 & 54.4 & 54.4 & 40.45 & \\
\hline 21 & 8 & 1989 & 8 & 53,4 & 53,4 & 29,87 & 18,54 \\
\hline 7 & 9 & 1989 & 7 & 65,6 & 65,6 & 33,78 & \\
\hline 14 & 12 & 1989 & 9 & 59,2 & 59,2 & 53,38 & \\
\hline 11 & 1 & 1990 & 18 & 73,9 & 124 & 40,25 & \\
\hline 13 & 1 & 1990 & & 50,1 & & & \\
\hline 19 & 3 & 1990 & 11 & 77 & 137,4 & 72,32 & \\
\hline 20 & 3 & 1990 & & 60.4 & & & 35.21 \\
\hline 11 & 5 & 1990 & 10 & 58,8 & 114,6 & 74,22 & \\
\hline 15 & 5 & 1990 & & 55,8 & & & \\
\hline 1 & 9 & 1990 & 11 & 58,2 & 111,3 & 55,93 & \\
\hline 29 & 9 & 1990 & & 53,1 & & & \\
\hline 19 & 10 & 1990 & 10 & 88,6 & & 43,8 & \\
\hline 25 & 1 & 1991 & 10 & 51,4 & & 25,69 & \\
\hline 30 & 11 & 1991 & 7 & 72,8 & & 59,53 & 20,94 \\
\hline 12 & 12 & 1991 & 17 & 119 & & 49.01 & $20, \sqrt{4}$ \\
\hline 25 & 3 & 1992 & 21 & 101,4 & & 39,08 & \\
\hline 20 & 4 & 1992 & 10 & 50,4 & 128,4 & 51,11 & \\
\hline 25 & 4 & 1992 & & 78 & & & 19,64 \\
\hline 2 & 5 & 1992 & 14 & 53 & & 15,11 & \\
\hline 5 & 9 & 1992 & 14 & 51,7 & & 19.88 & \\
\hline 6 & 1 & 1993 & 17 & 53,4 & & 24,02 & \\
\hline 17 & 2 & 1993 & 17 & 75,4 & & 40,43 & 16.94 \\
\hline 2 & 10 & 1993 & 9 & 50 & & 27.06 & \\
\hline 10 & 12 & 1993 & 14 & 51.6 & & 32.91 & \\
\hline 20 & 6 & 1994 & 5 & 58 & & 34,38 & 13,25 \\
\hline 10 & 1 & 1995 & 21 & 90,8 & & 25,88 & \\
\hline 24 & 9 & 1995 & 8 & 55,2 & & 32,09 & \\
\hline 16 & 10 & 1995 & 12 & 55,6 & 128,6 & 51,11 & 22,69 \\
\hline
\end{tabular}

continua... 


\begin{tabular}{|c|c|c|c|c|c|c|c|}
\hline 17 & 10 & 1995 & & 73 & & & \\
\hline 28 & 12 & 1995 & 12 & 68,2 & & 31,14 & \multirow{4}{*}{11.85} \\
\hline 19 & 3 & 1996 & 19 & 71,9 & & 36.85 & \\
\hline 1 & 4 & 1996 & 9 & 54.4 & & 57.69 & \\
\hline 17 & 12 & 1996 & 20 & 50 & & 19.96 & \\
\hline 11 & 2 & 1997 & 13 & 52,3 & 127 & 44,77 & \multirow[b]{4}{*}{25,92} \\
\hline 20 & 2 & 1997 & & 74,7 & & & \\
\hline 22 & 5 & 1997 & 6 & 56,6 & & 59,14 & \\
\hline 5 & 6 & 1997 & 15 & 99,7 & 172.7 & 53,99 & \\
\hline 14 & 6 & 1997 & & 73 & & & \\
\hline 20 & 10 & 1997 & 14 & 118,4 & 179,2 & 52,06 & \\
\hline 26 & 10 & 1997 & & 60,8 & & & \multirow{4}{*}{8.59} \\
\hline 3 & 11 & 1997 & 19 & 64,2 & & 24.19 & \\
\hline 14 & 3 & 1998 & 15 & 75,7 & & 29,93 & \\
\hline 29 & 9 & 1998 & 15 & 63.2 & & 20.71 & \\
\hline 2 & 1 & 1999 & 14 & 56,8 & & 29,96 & \multirow{4}{*}{18,6} \\
\hline 16 & 4 & 1999 & 5 & 53,2 & & 56,6 & \\
\hline 7 & 5 & 1999 & 6 & 68,7 & & 80,63 & \\
\hline 14 & 12 & 1999 & 13 & 58.4 & & 29,36 & \\
\hline 14 & 2 & 2000 & 14 & 116,2 & 188,6 & 50.85 & \multirow{3}{*}{16,73} \\
\hline 22 & 2 & 2000 & & 72,4 & & & \\
\hline 28 & 8 & 2000 & 12 & 68,3 & & 43,73 & \\
\hline 10 & 3 & 2001 & 15 & 57 & & 28,92 & 8,85 \\
\hline 11 & 12 & 2001 & 13 & 75 & & 32.87 & \multirow{6}{*}{24,87} \\
\hline 18 & 5 & 2002 & \multirow{3}{*}{12} & 84,2 & 233,2 & 62,49 & \\
\hline 20 & 5 & 2002 & & 90 & & & \\
\hline 21 & 5 & 2002 & & 59 & & & \\
\hline 16 & 9 & 2002 & 11 & 53,2 & & 39,44 & \\
\hline 11 & 11 & 2002 & 13 & 62,6 & & 31,74 & \\
\hline 26 & 1 & 2003 & 17 & 56,1 & 106.5 & 38,08 & \multirow{5}{*}{18,2} \\
\hline 27 & 1 & 2003 & & 50,4 & & & \\
\hline 11 & 2 & 2003 & 16 & 51,4 & & 22,39 & \\
\hline 7 & 8 & 2003 & 5 & 60.1 & & 71,63 & \\
\hline 27 & 10 & 2003 & 7 & 50,8 & & 50,7 & \\
\hline 8 & 1 & 2004 & 10 & 70.8 & & 46.46 & \multirow{7}{*}{27,84} \\
\hline 15 & 3 & 2004 & 8 & 55 & & 35.6 & \\
\hline 24 & 4 & 2004 & 9 & 57.4 & & 47.36 & \\
\hline 13 & 5 & 2004 & 17 & 65,7 & & 21,6 & \\
\hline 19 & 10 & 2004 & \multirow[t]{2}{*}{11} & 52,6 & \multirow[t]{2}{*}{120,2} & \multirow[t]{2}{*}{53,73} & \\
\hline 24 & 10 & 2004 & & 67,6 & & & \\
\hline 5 & 11 & 2004 & 12 & 74,4 & & 28,71 & \\
\hline 4 & 4 & 2005 & 9 & 53,1 & 104,3 & 67,2 & \multirow{3}{*}{11,78} \\
\hline 25 & 4 & 2005 & & 51.2 & & & \\
\hline 19 & 11 & 2005 & 8 & 60.5 & & 56.17 & \\
\hline 29 & 1 & 2006 & 14 & 81,2 & & 54,9 & \multirow{4}{*}{27,3} \\
\hline 23 & 2 & 2006 & 13 & 101,2 & & 48,63 & \\
\hline 25 & 3 & 2006 & 12 & 86,7 & & 40,23 & \\
\hline 21 & 12 & 2006 & 13 & 117,4 & & 43.51 & \\
\hline
\end{tabular}

Org.: Domingues, I.A.S. (2008).

Nos anos de 1983 e 1984, houve sete dias com chuvas, distribuídos em cinco meses a cada ano. Essas chuvas representaram $22,9 \%$ e $39,2 \%$ do total anual, respectivamente. Os percentuais em relação ao total mensal ficaram entre $24,0 \%$ e $60,0 \%$.

Em 1985, houve apenas um dia no mês de junho com chuva acima de $50 \mathrm{~mm}$, o que representou $65,4 \%$ do total de chuva mensal e $5,6 \%$ do total anual. Para o ano de 1986, as chuvas ocorreram em três dias durante três meses, com totais que representaram $5,65 \%$ do total anual e $16,29 \%$ do total mensal.

Em 1987, a chuva foi distribuída em oito dias, um em cada mês, representando $28,36 \%$ do total anual e $29 \%$ a $48 \%$ do total mensal. Para o ano de 
1988, a chuva aconteceu em dois dias durante dois meses. Os percentuais foram de $11,05 \%$ do total anual e de $30 \%$ a $37 \%$ do total mensal.

Em 1989, as chuvas ocorreram em cinco dias durante cinco meses. Essas chuvas representaram $18,5 \%$ do total anual, e do total mensal variaram entre $29,0 \%$ a $53,0 \%$.

No ano de 1990, as chuvas acima de $50 \mathrm{~mm}$ foram distribuídas em cinco meses e em cada mês as elas ocorreram em dois dias, representando $35,2 \%$ do total anual $(1.635,7 \mathrm{~mm})$. As chuvas dos meses de março e maio foram as de maior total, representando $72,3 \%$ e $74,2 \%$ do total mensal. Em 1992, os maiores totais ocorreram nos meses de março (dia 25), abril (dias 20 e 25) e maio (dia 2), com $39 \%, 51 \%$ e $15 \%$ dos totais mensais $(259,5 \mathrm{~mm}, 251,2 \mathrm{~mm}$ e $350,7 \mathrm{~mm}$ );

No ano de 1996, os meses de março e abril tiveram chuvas de $71,9 \mathrm{~mm}$ (dia 19) e $54,4 \mathrm{~mm}$ (dia 1), correspondendo a $36,85 \%$ e $57,69 \%$ do total mensal. $\mathrm{O}$ ano de 1997 teve um total de chuvas acima de $50 \mathrm{~mm}, 26 \%$ do total anual $(2.1112 \mathrm{~mm})$. Nos meses de abril e maio de 1999, as chuvas dos dias 16/04 e 7/05 atingiram total de $56,6 \%$ e $80,6 \%$ do total mensal ( $94 \mathrm{~mm}$ e $85,2 \mathrm{~mm}$ ). Em 2002, choveu nos dias 18 , 20 e 21 de maio $62,49 \%$ do total mensal de $373,2 \mathrm{~mm}$, e para os meses de setembro e novembro os totais foram de $39,44 \%$ e $31,74 \%$ dos totais mensais $(134,9 \mathrm{~mm}$ e $197,2 \mathrm{~mm})$. Em 2004 o total desse tipo de chuva foi de $27,84 \%$ do total anual (1593,3mm). As chuvas ocorridas nos dias 4 e 25 de maio de 2005 representaram $67,2 \%$ do total mensal $(155,2 \mathrm{~mm})$, e no ano de 2006 as chuvas acima de $50 \mathrm{~mm}$ se concentraram principalmente no período considerado chuvoso (janeiro, fevereiro e dezembro), representando $27 \%$ do total anual $(1.416 \mathrm{~mm})$.

Dessa forma, verificou-se que em Cambé, na média, o número de dias com chuvas acima de $50 \mathrm{~mm}$ foi de 5,4 e em Mirador de 4,3. Neste município houve apenas quatro anos com maior número de dias com chuva nessa classe que em Cambé (Figura 41, A). 

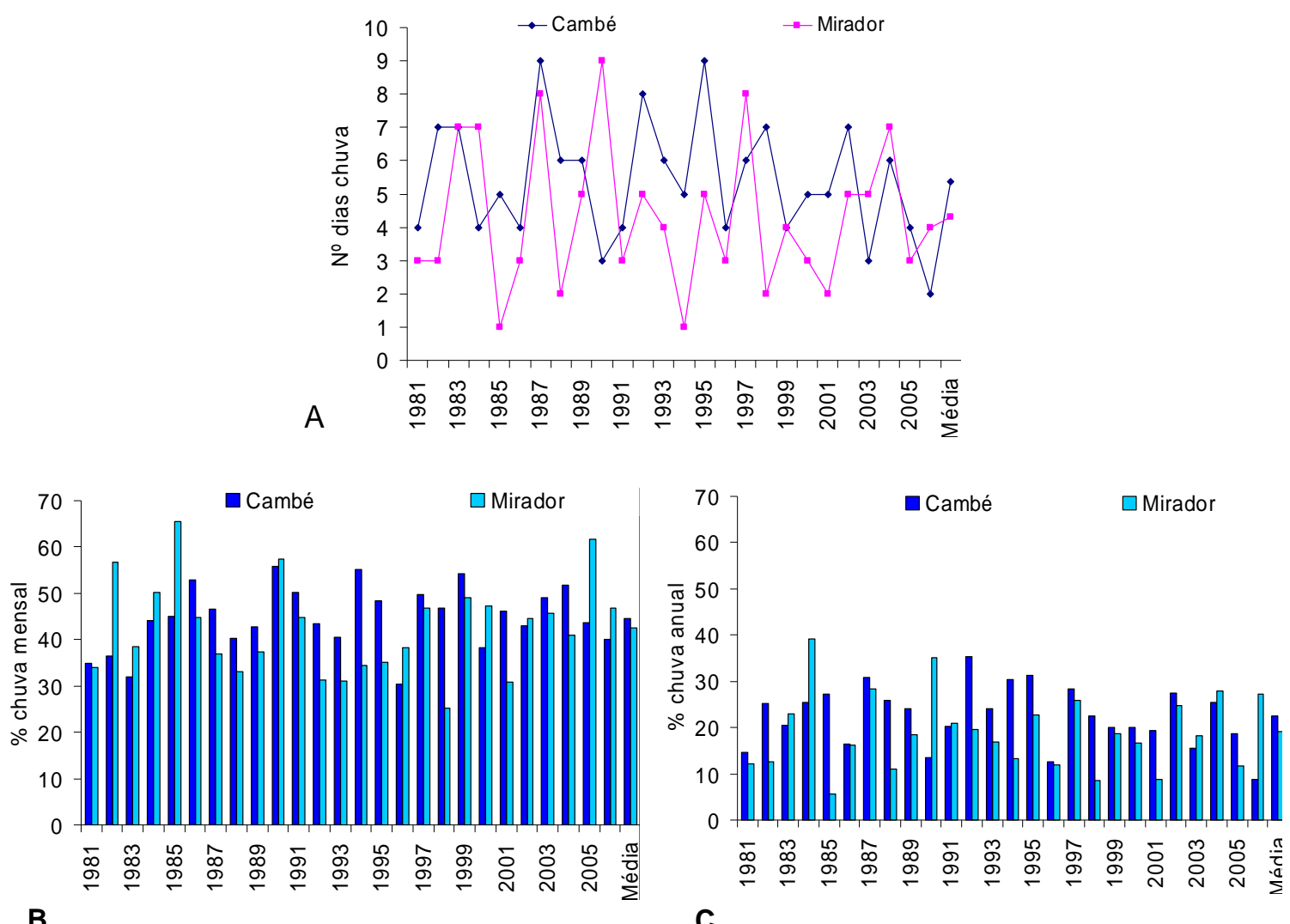

Figura 41 - Dias com chuva acima de $50 \mathrm{~mm}(\mathrm{~A})$, média do percentual dos meses com chuvas acima de $50 \mathrm{~mm}$ em relação ao total de chuva mensal (B) e percentual das chuvas acima de $50 \mathrm{~mm}$ em relação ao total de chuva anual (C), período de 1981 a 2006.

Org.: Domingues, I.A.S. (2008).

Para essas chuvas mensais, em relação ao total mensal, a média do período foi de 44,7\% em Cambé e de 42,6\% em Mirador. Neste município houve 10, dentre os 26 anos, com médias maiores que as de Cambé (Figura 41, B).

Quanto aos percentuais dos totais mensais em relação aos totais anuais, verificou-se que a média foi de 18,61\% em Cambé e de 11,78\% em Mirador. Dos 26 anos, apenas cinco apresentaram valores maiores que os de Cambé (Figura 41, C).

Por fim, esses dados esclarecem que as chuvas acima de $50 \mathrm{~mm}$, para a maioria dos anos, ocorrem com alta frequência, além de apresentar os maiores totais. 


\subsection{2 - Temperatura}

A temperatura do ar teve a seguinte evolução temporal de acordo com a Figura 42:

A temperatura média anual em Cambé foi de $21^{\circ} \mathrm{C}$, com a maior média, $22,2^{\circ} \mathrm{C}$, ocorrida no ano de 2002 , e a menor foi de $19,7^{\circ} \mathrm{C}$, em 1976 . Quanto às médias das temperaturas máximas e mínimas anuais, a maior e a menor máxima registradas foram de $28,7 \stackrel{\circ}{\circ}$ e $25,7 \stackrel{\circ}{ } \mathrm{C}$; para as mínimas, os extremos foram de $16,9^{\circ} \mathrm{C}$ e $14,9 \stackrel{\circ}{\circ} \mathrm{C}$, respectivamente.

No que diz respeito às médias mensais do período para essa variável, teve-se no mês de janeiro a mais elevada, $23,9^{\circ} \mathrm{C}$, seguida de fevereiro, com $23,8^{\circ} \mathrm{C}$, e dezembro, com $23,7^{\circ} \mathrm{C}$; as mais reduzidas temperaturas médias ocorreram nos meses de junho e julho, com $16,9^{\circ} \mathrm{C}$, e agosto, com $18,8^{\circ} \mathrm{C}$. As temperaturas dos meses de março, abril e maio foram de $23,4^{\circ} \mathrm{C}, 21,6^{\circ} \mathrm{C}$ e $18,3^{\circ} \mathrm{C}$, e as de setembro, outubro e novembro de $18,8^{\circ} \mathrm{C}, 22,1^{\circ} \mathrm{C}$ e $23,1^{\circ} \mathrm{C}$.

As médias mais elevadas da temperatura máxima foram registradas nos meses de fevereiro e março $\left(29,7^{\circ} \mathrm{C}\right)$ seguidas de janeiro $\left(29,6^{\circ} \mathrm{C}\right)$ e dezembro e novembro $\left(29,5^{\circ} \mathrm{C}\right)$; a menor máxima ocorreu no mês de junho, com temperatura média de 23,1ํㅜ; para a temperatura mínima, as médias mais reduzidas ocorreram nos meses de julho $\left(11,6^{\circ} \mathrm{C}\right)$, junho $\left(12,0^{\circ} \mathrm{C}\right)$ e agosto $\left(12,8^{\circ} \mathrm{C}\right)$ e a mínima mais elevada no mês de janeiro $\left(19,6^{\circ} \mathrm{C}\right)$.

A temperatura média anual em Mirador teve o seguinte comportamento (Figura 42): para a série temporal de 31 anos, a média foi de $22,2^{\circ} \mathrm{C}$, sendo que a mais elevada ocorreu no ano de $2002\left(23,3^{\circ} \mathrm{C}\right)$ e a mais reduzida no ano de 1976 $\left(20,9^{\circ} \mathrm{C}\right)$; de 1976 a 1993 , as médias anuais oscilaram entre $20,9^{\circ} \mathrm{C}$ e $22,6^{\circ} \mathrm{C}$, e a partir de 1994 as médias ficaram acima de $22^{\circ} \mathrm{C}$, uma diferença de $0,4^{\circ} \mathrm{C}$ a mais para esse segundo subperíodo. Quanto à média da temperatura máxima e mínima, constatou-se que a média da temperatura máxima foi de $28,4^{\circ} \mathrm{C}$, sendo a mais elevada registrada no ano de $2002\left(29,6^{\circ} \mathrm{C}\right)$ e a mais reduzida no ano de 1976 (27, $\left.0^{\circ} \mathrm{C}\right)$; a média da temperatura mínima foi de $17,8^{\circ} \mathrm{C}$, com a mínima mais elevada registrada no ano de $2002\left(18,8^{\circ} \mathrm{C}\right)$ e a mais reduzida no ano de $1976\left(16,6^{\circ} \mathrm{C}\right)$. 


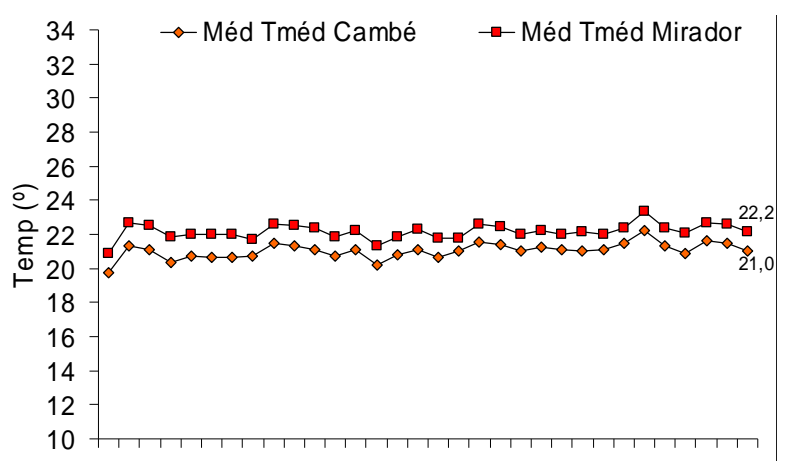

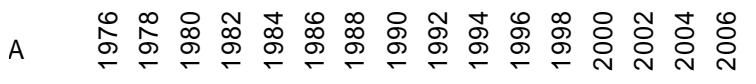
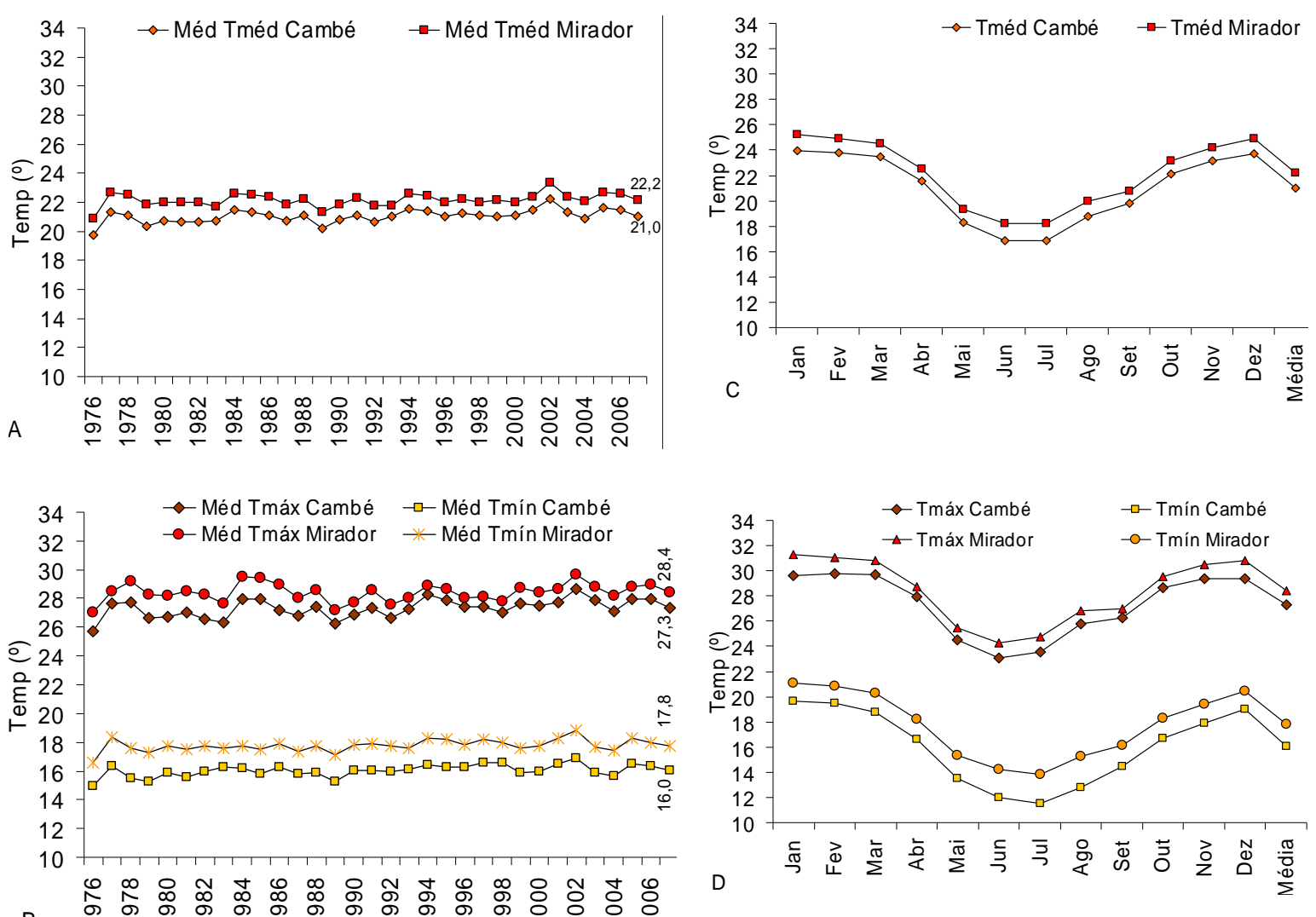

Figura 42 - Temperatura média anual (A, B) e mensal (C, D) do período de 1976 a 2006 dos municípios de Cambé e Mirador.

Org.: Domingues, I.A.S. (2008).

Em relação às temperaturas mensais do período, verificou-se a média de todos os meses de $22,2^{\circ} \mathrm{C}$, com a mais elevada ocorrida no mês de janeiro $\left(25,2^{\circ} \mathrm{C}\right)$, seguido de fevereiro e dezembro $\left(24,9^{\circ} \mathrm{C}\right)$, e a mais reduzida nos meses de junho e julho $\left(18,2^{\circ} \mathrm{C}\right)$; nos meses de outono, as médias ficaram entre $24,6^{\circ} \mathrm{C}$ e $19,4^{\circ} \mathrm{C}$ e na primavera entre $20,8^{\circ} \mathrm{C}$ e $24,2^{\circ} \mathrm{C}$. Com referência às temperaturas máximas e mínimas, registrou-se que a média da máxima mais elevada ocorreu no mês de janeiro $\left(31,3^{\circ} \mathrm{C}\right)$, seguida de fevereiro $\left(31,1^{\circ} \mathrm{C}\right)$, e a menor média em junho $\left(24,3^{\circ} \mathrm{C}\right)$; a média da mínima mais elevada aconteceu no mês de janeiro $\left(21,1^{\circ} \mathrm{C}\right)$ e a mais reduzida foi registrada no mês de julho $\left(13,9^{\circ} \mathrm{C}\right)$; os meses de janeiro a março e dezembro apresentaram médias das mínimas acima de $20^{\circ} \mathrm{C}$.

Segundo Magalhães (1987), ambientes favoráveis ao bom desenvolvimento do cultivo da cana-de-açúcar são aqueles que, dentre outros, apresentam temperaturas que podem oscilar entre $16^{\circ} \mathrm{C}$ e $33^{\circ} \mathrm{C}$. 
Dessa forma, temperaturas inferiores a $16^{\circ} \mathrm{C}$ sairiam da zona de condições aptas a esse cultivo, pois uma área, para apresentar aptidão marginal à temperatura do mês de julho, deve ser superior a 14ํㅡ (CAMARGO et al., 1977). As Figuras $43 \mathrm{e}$ 44 apresentam o número de dias em que ocorreram temperaturas abaixo de $16^{\circ} \mathrm{C}$.

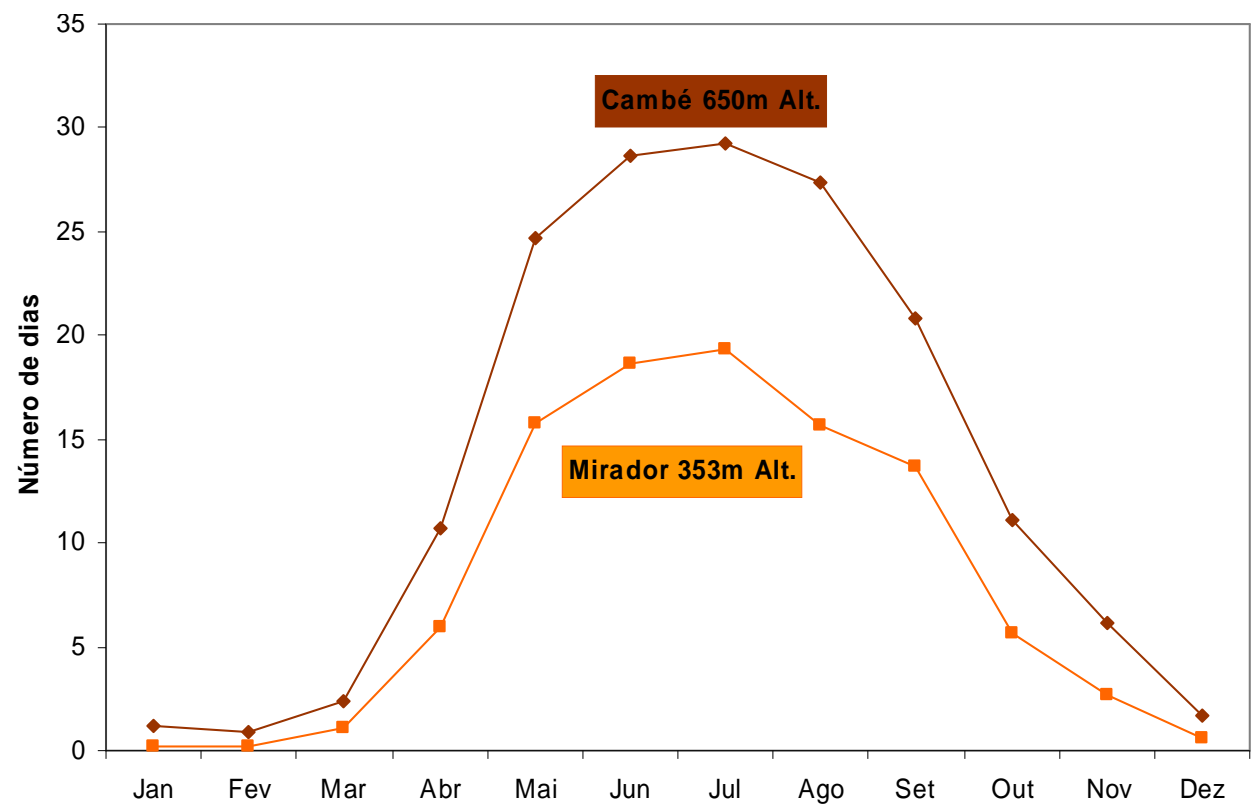

Figura 43 - Média mensal do número de dias do período (1976 a 2006) com temperatura abaixo de $16^{\circ} \mathrm{C}$ para os municípios de Cambé e Mirador, PR.

Org.: Domingues, I.A.S. (2008).

O número de dias com temperaturas inferiores a $16^{\circ} \mathrm{C}$ é distinto entre as localidades estudadas. A ocorrência de dias com essa temperatura é maior em Cambe, com percentuais que podem variar de 60\% a 100\%. Em Cambé os meses com menor número de dias com essa temperatura foram os de dezembro, janeiro e fevereiro ( 1 e 2 dias). Os meses com maior número de dias foram os de maio a setembro (20 a 29 dias), sendo julho o mês com mais dias. Em Mirador os meses de maior e menor número de dias são os mesmos, mudando os valores. Para os meses de verão, o número de dias foi de até 0,61 e de maio a setembro de 13,68 a 19,29 dias; 


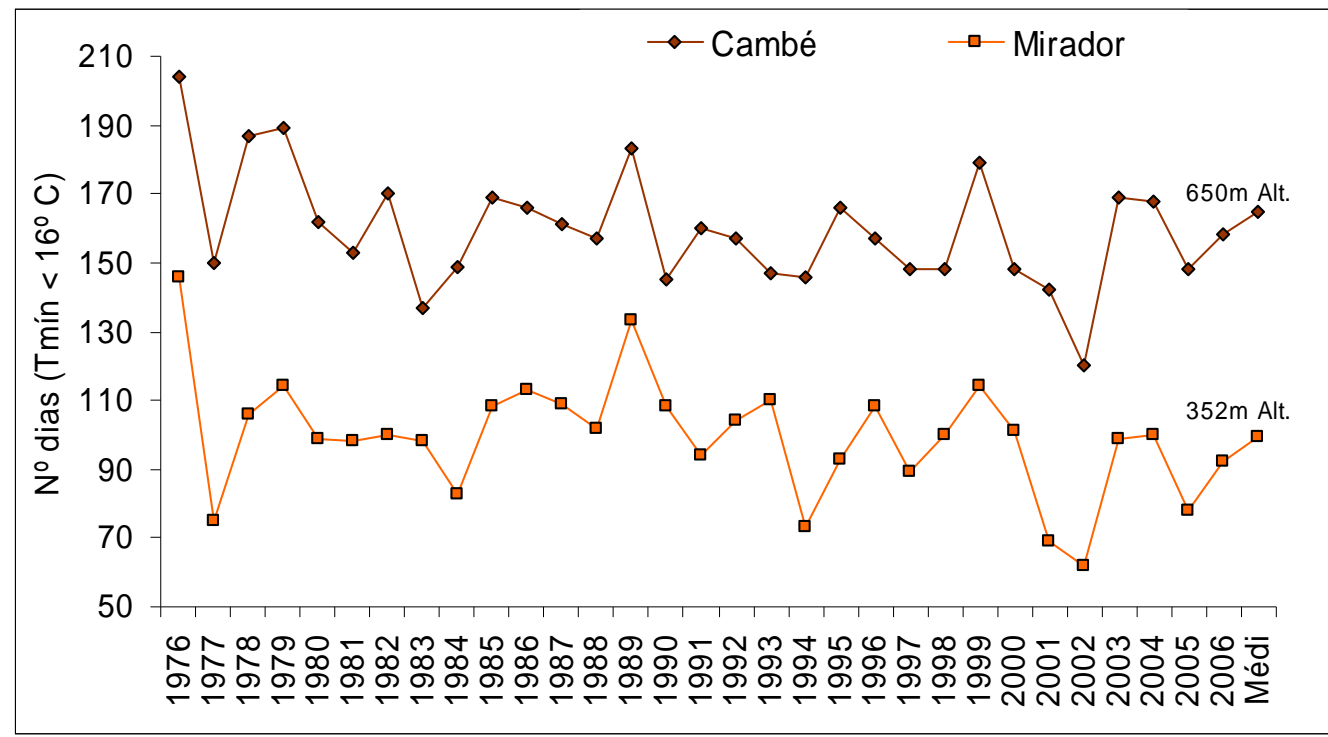

Figura 44 - Número de dias por ano do período (1976 a 2006) com temperatura abaixo de $16^{\circ} \mathrm{C}$ para os municípios de Cambé e Mirador, PR.

Org.: Domingues, I.A.S. (2008).

Quanto ao número de dias por ano com temperatura inferior a $16^{\circ} \mathrm{C}$, a média foi de 164,7 dias em Cambé e de 99,2 dias em Mirador (Figura 44). Em Cambé os anos com menos dias com essa temperatura foram os de 1977 (150 dias), 1983 (137 dias) e 2002 (120 dias). E os anos com mais dias foram os de 1976 (204 dias), 1989 (183 dias) e 1999 (179 dias). Segundo Nagarolli (2007), os anos de 1971, 1977, 1983, e 1998 apresentaram as maiores variabilidades nas temperaturas mínimas, principalmente nas regiões Norte e Noroeste do Paraná.

Em Mirador os anos com menos dias com essa temperatura foram os de 1977 (75), 1994 (73), 2001 (60) e 2002 (62 dias). E os anos com mais dias foram os de 1976 (146 dias), 1989 (133 dias) e 1999 (114 dias).

\section{7 - Análise das condições hídrica e térmica na produtividade da cultura da cana-de-açúcar nos municípios de Cambé e Mirador, PR}

4.7.1 - Correlação dos dados de chuva e temperatura com os dados de produtividade da cana-de-açúcar 
Conforme ilustrado na Tabela 19, a média de chuva para o período de 30 anos foi de 1604,0mm em Cambé e de 1485,0mm em Mirador. A média da temperatura para o mesmo período foi de $21,0^{\circ} \mathrm{C}$ para o primeiro município e de $22,2^{\circ} \mathrm{C}$ para o segundo. E a média de produtividade corrigida foi de 82,4 ton/ha e 76,2 ton/ha, respectivamente. De acordo com Nagarolli (2007), a média do total anual de chuva para o Norte do Paraná é em torno de $1.600 \mathrm{~mm}$ a $1.500 \mathrm{~mm} / \mathrm{ano}^{-1}$.

Tabela 19 - Dados de chuva anual, temperatura média anual e produtividade e seus desvios em relação à média $\left(\mathrm{d}_{\mathrm{i}}\right)$ e coeficiente de correlação (r) no período de 1981/82 a 2005/06 para os municípios de Mirador e Cambé.

\begin{tabular}{|c|c|c|c|c|c|c|c|c|c|c|c|c|}
\hline \multirow{3}{*}{$\begin{array}{c}\text { Ano } \\
\text { agrícola }\end{array}$} & \multicolumn{12}{|c|}{ Município } \\
\hline & \multicolumn{6}{|c|}{ Cambé } & \multicolumn{6}{|c|}{ Mirador } \\
\hline & \begin{tabular}{|l}
$\begin{array}{l}\text { Chuva } \\
(\mathrm{mm})\end{array}$ \\
\end{tabular} & $d_{i}$ & \begin{tabular}{|l|}
$\begin{array}{l}\text { Tméd } \\
(\mathbf{0})\end{array}$ \\
\end{tabular} & $d_{i}$ & \begin{tabular}{|l|}
$\begin{array}{l}\text { Produt } \\
\text { (ton/ha) }\end{array}$ \\
\end{tabular} & $d_{i}$ & $\begin{array}{l}\text { Chuva } \\
\text { (mm) }\end{array}$ & $d_{i}$ & $\begin{array}{l}\text { Tméd } \\
\left({ }^{\circ} \mathrm{C}\right)\end{array}$ & $d_{i}$ & \begin{tabular}{|l|}
$\begin{array}{l}\text { Produt } \\
\text { (ton/ha) }\end{array}$ \\
\end{tabular} & $\mathbf{d}_{\mathrm{i}}$ \\
\hline $1981 / 82$ & 1749,7 & 146 & 20,7 & $-0,3$ & 115,6 & 33,2 & 1478 & -7 & 22,0 & $-0,2$ & 78,1 & 1,9 \\
\hline $1982 / 83$ & 2141,4 & 537 & 20,9 & $-0,1$ & 90,8 & 8,4 & 2061,3 & 576,3 & 21,9 & $-0,3$ & 79,5 & 3,3 \\
\hline $1983 / 84$ & 1542,8 & -61 & 21,1 & 0,1 & 57,6 & $-24,8$ & 1233,1 & $-251,9$ & 22,2 & 0,0 & 62,4 & $-13,8$ \\
\hline $1984 / 85$ & 1432,4 & -172 & 20,9 & $-0,1$ & 68,9 & $-13,5$ & 1463,5 & $-21,5$ & 22,0 & $-0,2$ & 79,1 & 2,9 \\
\hline $1985 / 86$ & 1147,7 & -456 & 21,6 & 0,6 & 80,7 & $-1,8$ & 1270,7 & $-214,3$ & 22,9 & 0,7 & 78,8 & 2,6 \\
\hline $1986 / 87$ & 1595,9 & -8 & 20,8 & $-0,2$ & 79,2 & $-3,2$ & 1429,8 & $-55,2$ & 22,0 & $-0,2$ & 73,6 & $-2,6$ \\
\hline $1987 / 88$ & 1708,8 & 105 & 20,8 & $-0,2$ & 78,6 & $-3,8$ & 1363,5 & $-121,5$ & 21,9 & $-0,3$ & 70,2 & $-6,0$ \\
\hline $1988 / 89$ & 1394,4 & -210 & 20,7 & $-0,3$ & 66,4 & $-16,0$ & 1466,8 & $-18,2$ & 21,8 & $-0,4$ & 89,0 & 12,8 \\
\hline $1989 / 90$ & 1777,4 & 173 & 20,4 & $-0,6$ & 68,9 & $-13,5$ & 1523,4 & 38,4 & 21,5 & $-0,7$ & 68,0 & $-8,2$ \\
\hline $1990 / 91$ & 1259,9 & -344 & 21,0 & 0,0 & 81,3 & $-1,1$ & 1228,6 & $-256,4$ & 22,2 & 0,0 & 67,4 & $-8,8$ \\
\hline 1991/92 & 1910,5 & 307 & 20,9 & $-0,1$ & 97,6 & 15,2 & 1614,5 & 129,5 & 22,1 & $-0,1$ & 77,3 & 1,1 \\
\hline $1992 / 93$ & 1711,1 & 107 & 20,7 & $-0,3$ & 83,0 & 0,6 & 1375,3 & $-109,7$ & 21,5 & $-0,7$ & 76,8 & 0,6 \\
\hline $1993 / 94$ & 1602,1 & -2 & 21,3 & 0,3 & 74,9 & $-7,5$ & 1442,4 & $-42,6$ & 22,3 & 0,1 & 80,5 & 4,3 \\
\hline $1994 / 95$ & 1518,8 & -85 & 21,8 & 0,8 & 90,2 & 7,8 & 1210,3 & $-274,7$ & 22,9 & 0,7 & 96,2 & 20,0 \\
\hline $1995 / 96$ & 1950,4 & 346 & 21,0 & 0,0 & 102,7 & 20,3 & 1465,1 & $-19,9$ & 22,0 & $-0,2$ & 84,7 & 8,5 \\
\hline $1996 / 97$ & 2277,2 & 673 & 21,0 & 0,0 & 78,0 & $-4,4$ & 1952,9 & 467,9 & 21,9 & $-0,3$ & 77,7 & 1,5 \\
\hline $1997 / 98$ & 1853,8 & 250 & 21,4 & 0,4 & 87,6 & 5,2 & 1835,6 & 350,6 & 22,4 & 0,2 & 86,3 & 10,1 \\
\hline $1998 / 99$ & 1740,7 & 137 & 20,9 & $-0,1$ & 89,2 & 6,8 & 1564,7 & 79,7 & 21,9 & $-0,3$ & 77,1 & 0,9 \\
\hline $1999 / 00$ & 1226,1 & -378 & 20,9 & $-0,1$ & 78,8 & $-3,6$ & 1351,6 & $-133,4$ & 22,0 & $-0,2$ & 54,3 & $-21,9$ \\
\hline $2000 / 01$ & 1718,3 & 114 & 21,5 & 0,5 & 91,1 & 8,7 & 1516,3 & 31,3 & 22,5 & 0,3 & 68,4 & $-7,8$ \\
\hline $2001 / 02$ & 1567 & -37 & 22,0 & 1,0 & 75,2 & $-7,2$ & 1470,7 & $-14,3$ & 23,1 & 0,9 & 76,2 & 0,0 \\
\hline $2002 / 03$ & 1314,8 & -289 & 21,6 & 0,6 & 102,8 & 20,4 & 1500,5 & 15,5 & 22,6 & 0,4 & 65,2 & $-11,0$ \\
\hline $2003 / 04$ & 1361,4 & -243 & 20,8 & $-0,2$ & 88,8 & 6,4 & 1473,3 & $-11,7$ & 22,0 & $-0,2$ & 80,2 & 4,0 \\
\hline $2004 / 05$ & 1324,1 & -280 & 21,8 & 0,8 & 58,0 & $-24,4$ & 1299,1 & $-185,9$ & 23,0 & 0,8 & 78,0 & 1,8 \\
\hline $2005 / 06$ & 1300,1 & -304 & 21,2 & 0,2 & 74,3 & $-8,1$ & 1429,4 & $-55,6$ & 22,3 & 0,1 & 81,2 & 5,0 \\
\hline Média & 1604 & & 21,0 & & 82,4 & & 1485 & & 22,2 & & 76,2 & \\
\hline$r$ & & 0,31 & & $-0,07$ & & & & 0,18 & & 0,17 & & \\
\hline
\end{tabular}

Org.: Domingues, I.A.S. (2009).

No município de Cambé os maiores totais de chuva ocorreram nos anos agrícolas de 1982/83, com desvio positivo de 537mm, e 1996/97, com desvio de 
$673 \mathrm{~mm}$. Os anos agrícolas de 1985/86 e 1999/00 apresentaram os menores totais, com desvios negativos de $456 \mathrm{~mm}$ e $378 \mathrm{~mm}$, respectivamente. Para a temperatura, a mais elevada foi no ano agrícola de $2001 / 02$, com desvio positivo de $1,0^{\circ} \mathrm{C}$, e a mais reduzida em 1989/90, com desvio negativo de 0,6ㅜㅡ. Nagarolli (2007) utilizou série temporal de 1970 a 1999 e verificou que ocorreram chuvas abaixo de $1.100 \mathrm{~mm}$, principalmente nos anos de 1984, 1985, 1988, 1991, 1994 e 1999. Para a produtividade, os maiores desvios positivos foram de 33,2 ton/ha em 1981/82 e de 20,4 em 2002/03, enquanto os menores desvios foram de 24,8 ton/ha negativos em $1983 / 84$ e de 24,4 ton/ha em 2004/05.

Para Mirador os anos agrícolas com os maiores totais foram os mesmos de Cambé, com desvios positivos de $576,3 \mathrm{~mm}$ e de $467,9 \mathrm{~mm}$. Os menores totais de chuva ocorreram em 1990/91, com desvios negativos de 256,4mm, e em 1994/95, com $274,7 \mathrm{~mm}$. Quanto às temperaturas mais elevadas e mais reduzidas, estas tiveram desvio positivo em 2001/02, de 0,9º , e desvios negativos em 1989/90 e $1992 / 93$, de $0,7^{\circ} \mathrm{C}$. Os anos agrícolas que tiveram os maiores desvios negativos de produtividade foram os de 1983/84 e 1999/00 e os de 1988/89 e1994/95 os maiores desvios positivos.

De modo geral, os regimes pluviométricos são distintos nesses dois municípios estudados. O número de anos com desvios negativos tanto de chuva quanto de temperatura é maior em Mirador que em Cambé. Esses números de anos representam $12 \%$ do total para chuva e $8 \%$ para temperatura. Entretanto, houve $20 \%$ a mais de anos com desvios negativos de produtividade em Cambé (Figuras 45 e 46).

Os desvios de chuva foram coincidentes com os de produtividade em cinco anos, quando houve aumento no total de chuva e consequentemente aumento de produtividade, e seis anos com redução na variável independente (Figura $45 \mathrm{~A}$ e B). O valor do coeficiente de correlação para essas duas variáveis foi de $r=0,31$, considerado uma correlação moderada (Figura 47 A). Para temperatura e produtividade houve concordância de aumentos em quatro anos e redução em cinco anos (Figura $45 \mathrm{~B}$ ). Entretanto, o valor do coeficiente de correlação foi de $r=0,07$ negativo, considerado fraco, visto que uma perfeita correlação entre duas variáveis deveria estar entre -1 e/ou +1 (Figura 47 B). 

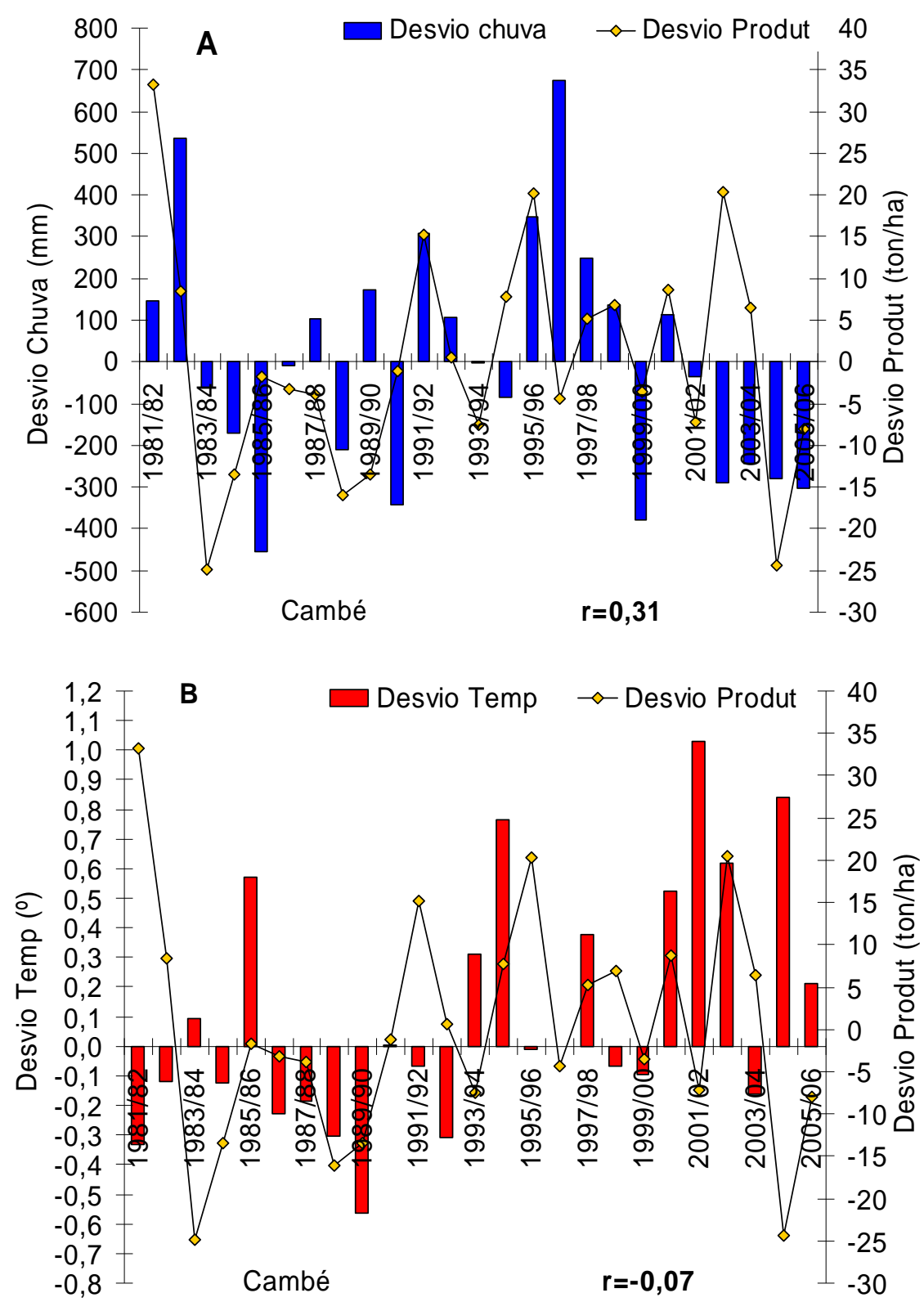

Figura 45 - Desvios de chuva e produtividade (A) e desvio de temperatura e produtividade (B), município de Cambé, anos agrícolas 1981/82 a 2005/06.

Org.: Domingues, I.A.S. (2009). 

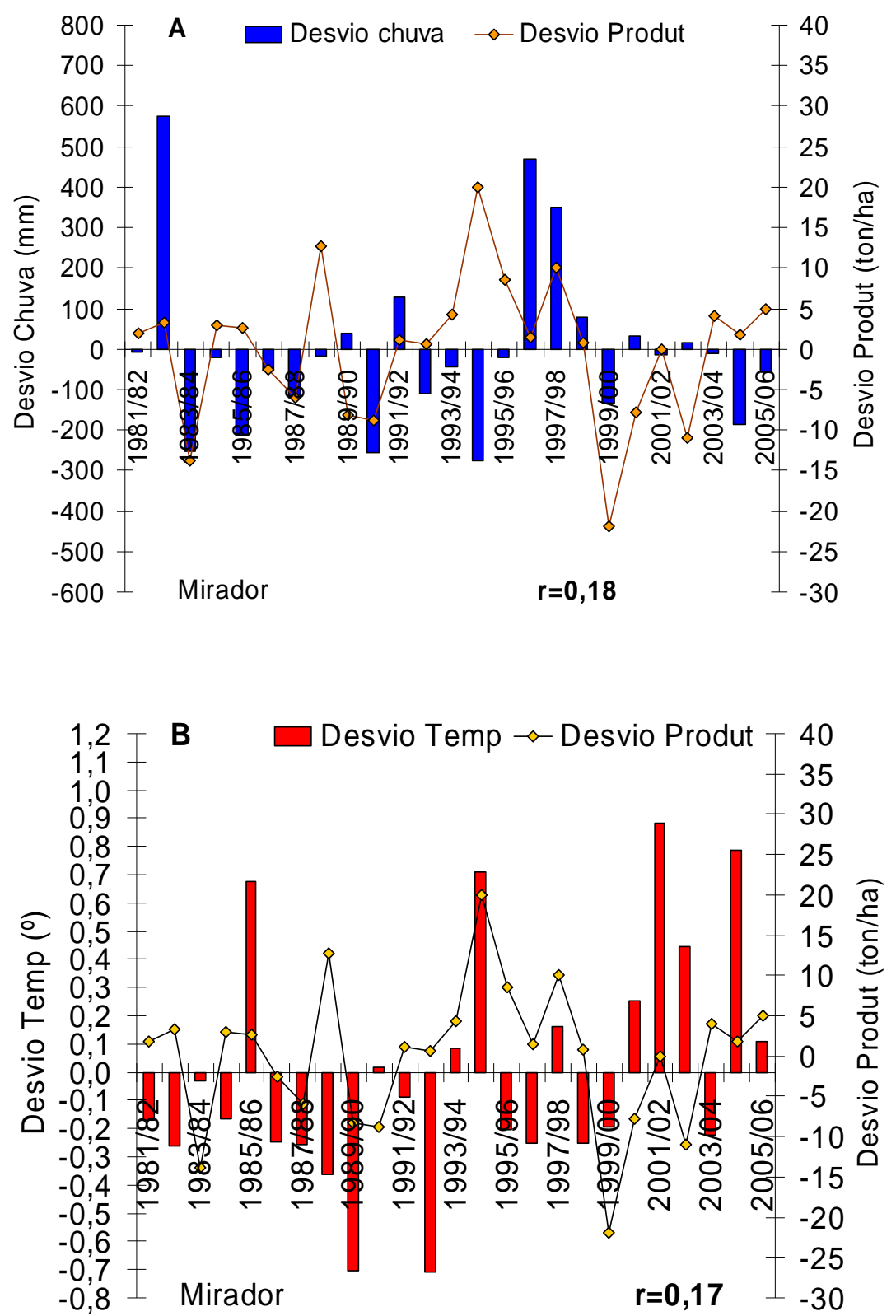

Figura 46 - Desvios de chuva e produtividade (A) e desvio de temperatura e produtividade (B), município de Mirador, anos agrícolas 1981/82 a 2005/06.

Org.: Domingues, I.A.S. (2009). 


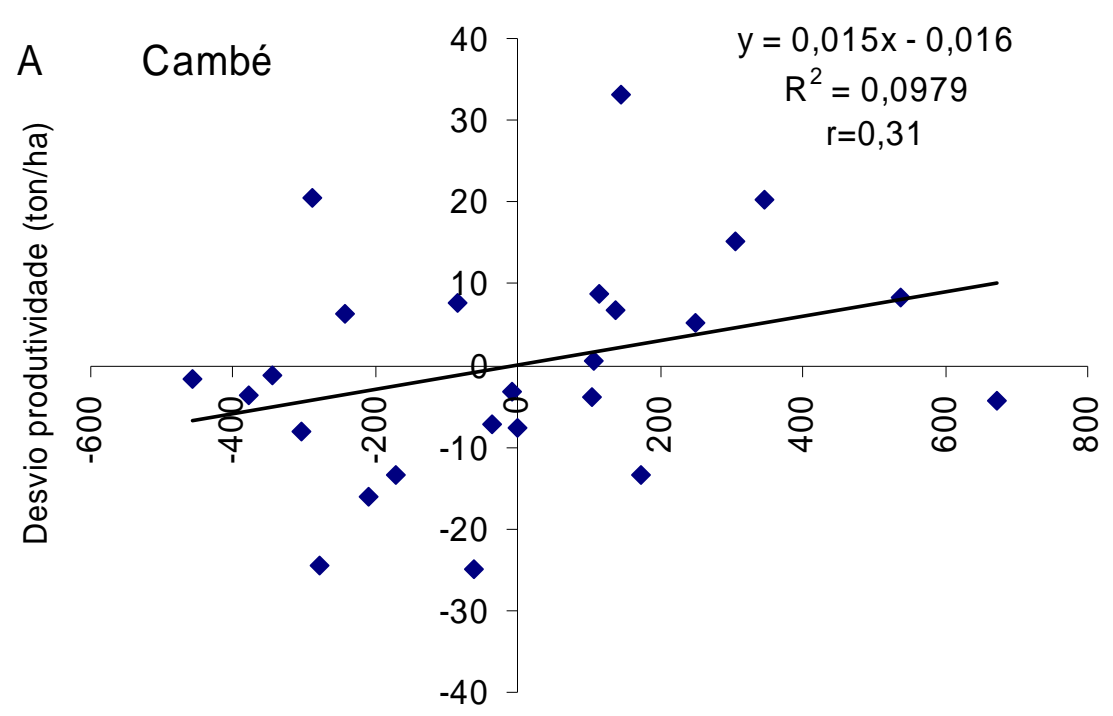

Desvio de chuva (mm)

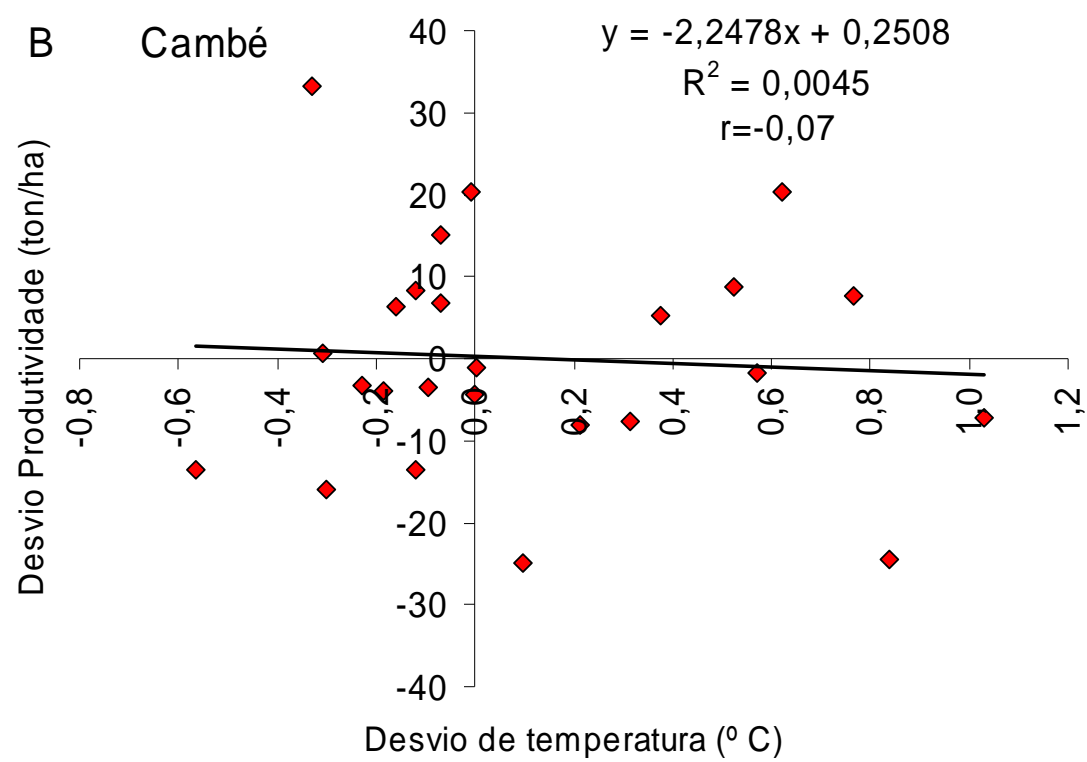

Figura 47 - Dispersão dos desvios de chuva com a produtividade da cana-de-açúcar (A) e de temperatura com a produtividade (B) do município de Cambé, anos agrícolas 1981/82 a 2005/06. Org.: Domingues, I.A.S. (2009).

Em Mirador ocorreram cinco anos com aumento nos totais de chuva e de produtividade e sete anos com redução (Figura 46 A). Os aumentos de temperatura e de produtividade em relação à média se deram durante seis anos, e houve oito anos de reduções (Figura 46 B). Entretanto, as correlações entre essas variáveis foram consideradas fracas, com coeficiente de correlação positivo de $r=0,18$ para 
chuva e produtividade e $r=0,17$ para temperatura e produtividade (Figura 48 A e B). Estudo no Médio Paranapanema, correlacionando totais de chuva com produtividade da cana-de-açúcar para um período de oito anos, determinou fraca correlação entre essas variáveis (SILVA, et al., 2008).
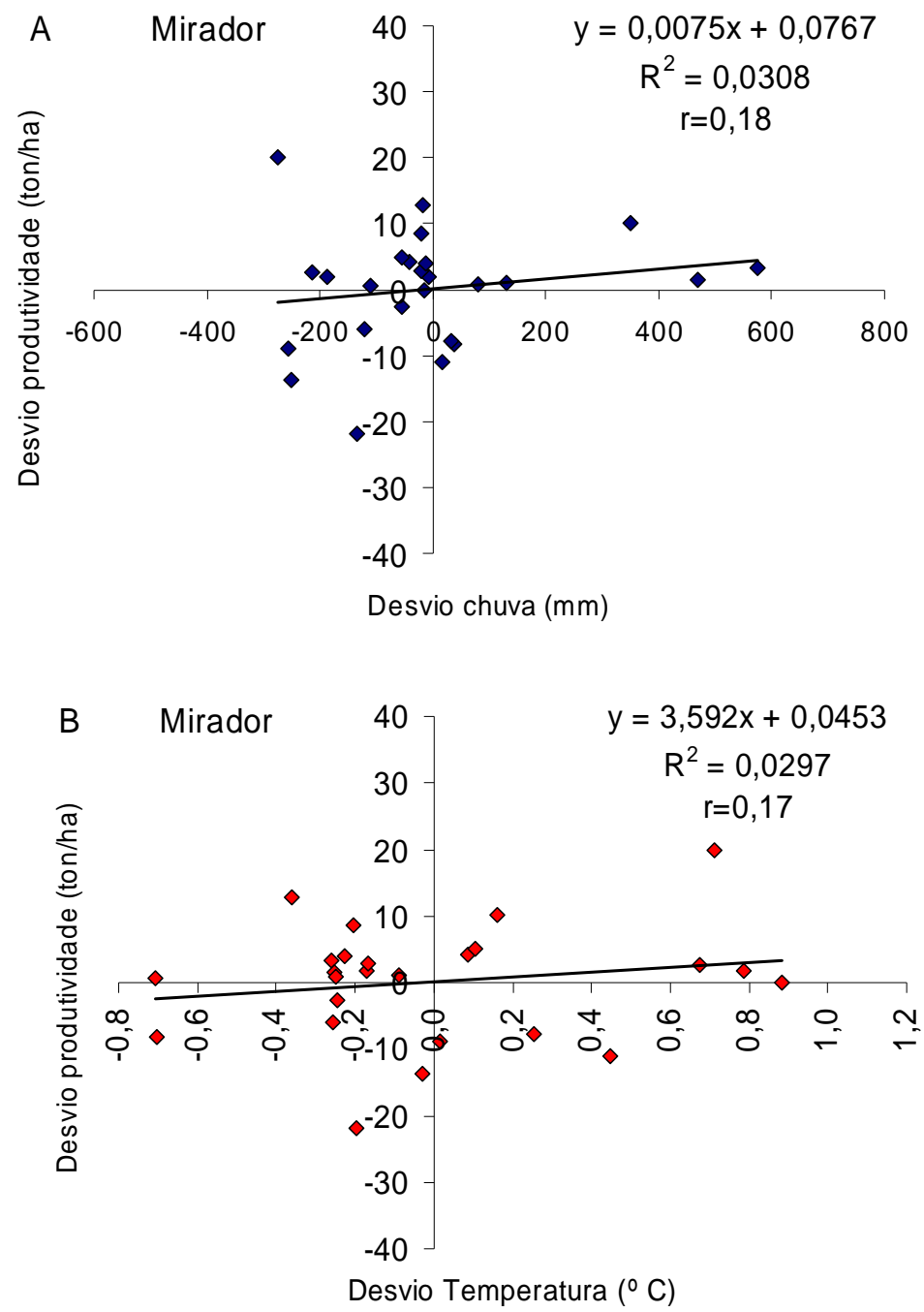

Figura 48 - Dispersão dos desvios de chuva e produtividade da cana-de-açúcar (A) e de temperatura com a produtividade (B), do município de Mirador, anos agrícolas 1981/82 a 2005/06.

Org.: Domingues, I.A.S. (2009).

A visualização da relação entre as variáveis chuva e produtividade e temperatura e produtividade está representada nos diagramas de dispersão (Figuras 
47 A e B e 48 A e B). Observa-se, por meio desses gráficos, que a correlação entre as variáveis é moderada somente para chuva e produtividade em Cambé; nos demais a correlação é considerada fraca. Segundo Santos (1981), totais médios de produtividade da cultura da cana-de-açúcar com totais médios de chuva tiveram correlação moderada.

Outro procedimento adotado foi a utilização das variáveis hídricas, EXC (excedente hídrico) e DEF (deficiencia hídrica), obtidas por meio do Balanço Hídrico Normal para a verificação da relação dessas com a produtividade.

\subsection{2 - Balanço Hídrico Normal e a produtividade da cultura da cana-de-açúcar}

As condições de variações da disponibilidade hídrica, excesso (EXC) ou deficiência (DEF), por exemplo, assumem importância fundamental tanto na caracterização regional e local quanto no acompanhamento do armazenamento de água no solo. Essas informações têm aplicações em diversas funções, sobretudo no zoneamento agroclimatológico, determinando os melhores períodos para cada estádio fenológico da cultura, além de fornecerem dados que identificam períodos de risco.

Esse procedimento possibilita, dentre outros, a quantificação de EXC e DEF hídrica e sua importância na produtividade, sendo o EXC hídrico essencial principalmente nas fases de desenvolvimento e a DEF na fase de maturação.

Assim, por meio do BH Normal, efetuaram-se os totais de EXC e DEF dos anos agrícolas de 1981/82 a 2005/06. Esses dados, bem como os de produtividade, foram submetidos ao desvio em relação à média e à análise de correlação (Tabela 20).

As médias de EXC e DEF para o período de 25 anos foram de $631,9 \mathrm{~mm}$ e 58,0mm em Cambé e de 457,7mm e 86,8mm em Mirador (Tabela 20). 
Tabela 20 - Dados de EXC $(\mathrm{mm}), \operatorname{DEF}(\mathrm{mm})$, produtividade (ton/ha), seus desvios $\left(\mathrm{d}_{\mathrm{i}}\right)$ em relação à média e coeficiente de correlação (r), anos agrícolas de 1981/82 a 2005/06 para Cambé e Mirador.

\begin{tabular}{|c|c|c|c|c|c|c|c|c|c|c|c|c|}
\hline & \multicolumn{6}{|c|}{ Cambé } & \multicolumn{6}{|c|}{ Mirador } \\
\hline $\begin{array}{l}\text { Ano } \\
\text { Agrícola }\end{array}$ & EXC & \begin{tabular}{|l}
$d_{i}$ \\
EXC
\end{tabular} & DEF & $\begin{array}{l}d_{i} \\
\text { DEF }\end{array}$ & Produt & \begin{tabular}{|l|}
$d_{i}$ \\
Produt
\end{tabular} & EXC & $\begin{array}{l}d_{i} \\
\text { EXC }\end{array}$ & DEF & $\begin{array}{l}d_{i} \\
\text { DEF }\end{array}$ & Produt & \begin{tabular}{|l|}
$d_{i}$ \\
Produt
\end{tabular} \\
\hline 19 & 5 & 74,6 & 2 & 1,9 & & 2 & 431,3 & $-26,4$ & 5,4 & 1,4 & 78,1 & 9 \\
\hline $1982 / 83$ & 1249,8 & 617,9 & 9 & $-3,1$ & 90,8 & 4 & 078,5 & 8 & 1,2 & $-35,6$ & 5 & 3,3 \\
\hline 198 & 559,4 & 2,5 & 3 & $-10,7$ & 6 & 24,8 & 242,4 & $-215,3$ & 108,3 & 21,6 & 4 & 3,8 \\
\hline 198 & 461,4 & $-170,5$ & 100,4 & 42,4 &, 9 & 3,5 & 340,2 & -1 & 87,8 & 1,0 & 9,1 & 2,9 \\
\hline $1985 / 86$ & 207,3 & $-424,5$ & 165,6 & 107,6 & 0,7 & $-1,8$ & 325,3 & $-132,4$ & 223,3 & 136,5 & 8,8 & 2,6 \\
\hline 198 & 773,5 & 141,6 & 1 & $-51,9$ & 2 & $-3,2$ & 512,5 & 4,9 & 107,7 & 20,9 & 6 & 6 \\
\hline $1987 / 88$ & 765,2 & 100,0 &,+\llcorner & $-23,8$ & 10,6 & $-3,8$ & 279,6 & 78,1 & 54,4 & 32,4 & $0,\llcorner$ & $-6,0$ \\
\hline 198 & 386,9 & $-245,0$ & 59,0 & 0,9 & 66,4 & $-16,0$ & 462,1 & 4,4 & 126,4 & 39,7 & 9,0 & 12,8 \\
\hline $1989 / 90$ & 811,0 & 179,1 & 56,7 & $-1,4$ & 68,9 & $-13,5$ & 507,4 & 49,7 & 57,7 & $-29,0$ & 68,0 & $-8,2$ \\
\hline $1990 / 91$ & 356,7 & $-275,2$ & 37,8 & $-20,2$ & 81,3 & $-1,1$ & 354,4 & $-103,3$ & 107,5 & 20,7 & 67,4 & $-8,8$ \\
\hline 199 & 9 & 282,1 & 7 & 21,3 & 97,6 & 15,2 & 561,2 & 103,5 & 146,5 & 59,8 & 77,3 & 1,1 \\
\hline 19 & & . & 3,1 & $-25,0$ & 0 & 6 & ד, & & 40,3 & $-46,5$ & 6,8 & 0,6 \\
\hline 195 & 625,9 & $-6,0$ & 8 & $-25,2$ & 4,9 & $-7,5$ & 314,2 & -14 & 24,3 & $-62,4$ & 0,5 & 4,3 \\
\hline $1994 / 95$ & 486,4 & $-145,5$ & 43,0 & $-15,0$ & 90,2 & 7,8 & 228,0 & $-229,7$ & 103,8 & 17,0 & 96,2 & 20,0 \\
\hline $1995 / 96$ & 586,0 & 5,9 & 83,7 & 25,7 & 102,7 & 20,3 & 424,0 & $-33,7$ & 49,7 & $-37,0$ & 84,7 & 8,5 \\
\hline $1996 / 97$ & 1243,8 & , 9 & 54,6 & $-3,4$ & 0 & $-4,4$ & 891,9 & 434,3 & 30,3 & $-56,4$ & ,7 & 1,5 \\
\hline 199 & 8 & 0 & 4 & $-43,6$ & 8 & 5,2 & 651,7 & 0 & 25,1 & $-61,6$ & 3 & 10,1 \\
\hline 195 & 64,2 & 132,4 & 37,3 & $-20,8$ & 89 & 6,8 & 579,6 & 12 & 44,8 & $-42,0$ & , & 0,9 \\
\hline $1999 / 00$ & 383,7 & $-248,2$ & 76,0 & 18,0 & 78,8 & $-3,6$ & 336,3 & $-121,3$ & 119,2 & 32,4 & 54,3 & $-21,9$ \\
\hline $2000 / 01$ & 679,8 & 7,9 &, 2 & $-48,9$ & 91,1 & 8,7 & 442,0 & $-15,7$ & 21,2 & $-65,5$ & 68,4 & $-7,8$ \\
\hline $2001 / 02$ & 523,8 & $-108,0$ & 84,4 & 26,4 & 5,2 & $-7,2$ & 402,9 & $-54,8$ & 151,7 & 64,9 & 6,2 & 0,0 \\
\hline $2002 / 03$ & 328,0 & $-303,8$ & 46,0 & $-12,1$ & 102,8 & 20,4 & 386,0 & $-71,6$ & 48,0 & $-38,7$ & 65,2 & $-11,0$ \\
\hline $2003 / 04$ & 427,6 & $-204,2$ & 17,6 & $-40,4$ & 88,8 & 6,4 & 436,1 & $-21,6$ & 59,7 & $-27,1$ & 80,2 & 4,0 \\
\hline $2004 / 05$ & 423,2 & $-208,7$ & 143,1 & 85,1 & 58,0 & $-24,4$ & 389,4 & $-68,3$ & 243,7 & 156,9 & 78,0 & 1,8 \\
\hline $2005 / 06$ & 380,0 & $-251,8$ & 78,2 & 20,1 & 74,3 & $-8,1$ & 447,2 & $-10,5$ & 70,9 & $-15,9$ & 81,2 & 5,0 \\
\hline Média & 631,9 & & 58,0 & & 82,4 & & 457,7 & & 86,8 & & 76,2 & \\
\hline & & 0,23 & & $-0,25$ & & & & 0,16 & & 0,00 & & \\
\hline
\end{tabular}

Org.: Domingues, I.A.S. (2009).

Dentro desse período, os anos agrícolas de 1982/83 e 1996/97 apresentaram os maiores totais de EXC, com valores de 1249,9mm e 1243,8mm em Cambé e de 1078,5mm e 891,9mm em Mirador. A produtividade nesses anos, em Cambé, ficou abaixo da média em 3,1 ton/ha e em 3,4 ton/ha, enquanto em Mirador os valores foram positivos em 3,3 ton/ha e 1,5 ton/ha, respectivamente (Tabela 20). Conforme Santos (1981), oscilação na produtividade, seja positiva, seja negativa, pode ocorrer por EXC ou DEF hídrica.

Quanto ao DEF, os maiores totais ocorreram nos anos agrícolas de 1985/86 e 2004/05 nos dois municípios, com valores de 165,6mm e 143,1mm em Cambé e de 
223,3mm e 243,9mm em Mirador. A produtividade em Cambé esteve abaixo da média em 1,8 ton/ha e 24,4 ton/ha e em Mirador acima da média com valores de 2,6 ton/ha e 1.8 ton/ha (Tabela 20).

Para esses anos agrícolas, o EXC e o DEF apresentaram valores em torno ou acima de $100 \%$ da média. Nessas condições, a produtividade, em Cambé, tendeu à redução, enquanto em Mirador se manteve muito próxima da média.

4.7.2.1 - Correlação dos dados de EXC e DEF (BH Normal) com os de produtividade da cana-de-açúcar

Para verificar a correlação das variáveis hídricas e produtividade relacionaram-se os dados de desvios positivos e negativos de EXC e DEF com os de produtividade (Figura 49, 50).

Em Cambé o coeficiente de correlação para o período dos anos agrícolas de 1981/82 a 2005/06 foi de $r=0,23$ para o EXC e a produtividade de $r=-0,25$ para a DEF e produtividade. Esses valores indicam que a correlação entre as variáveis hídricas com a produtividade foi de 23\% e 25\%. Para Mirador esses valores foram menores, com coeficiente de correlação de $r=0,16$ para o EXC e produtividade e $r=$ 0,00 para DEF e produtividade. Ou seja, para a primeira variável o percentual de correlação foi de $16,0 \%$ e para a segunda de $0,0 \%$. Os sinais dos coeficientes de correlação, quando positivos, revelam que quando há aumento nos valores da variável independente há aumento nos valores da variável dependente. Quando o sinal é negativo, tem-se redução da variável independente e aumento na dependente.

Os gráficos de dispersão corroboram os valores dos coeficientes de correlação por apresentarem os pontos de forma dispersa, ou seja, sem uma imagem definida. Essa situação revela fraca correlação entre as variáveis (Figura 50, A, B, C e D).

Quando se analisa o período de tempo em relação aos desvios, percebe-se que houve dois anos com desvios extremos de EXC, tanto em Cambé quanto em 
Mirador. Esse período refere-se aos anos agrícolas de 1982/83 e 1986/87, com desvio de produtividade também acima da média nesses dois municípios, embora tal ferido, quando comparado com aqueles imediatamente antecedentes, tenha registrado redução nos valores de produtividade (Figura 49, A e C).

Com relação aos extremos de desvios de DEF acima da média, estes ocorreram nos anos agrícolas de 1985/86 e 2004/05, nos dois municípios. Entretanto, em Cambé esses desvios foram menores que os de Mirador em torno de 50mm (Figura 49, B e D). 

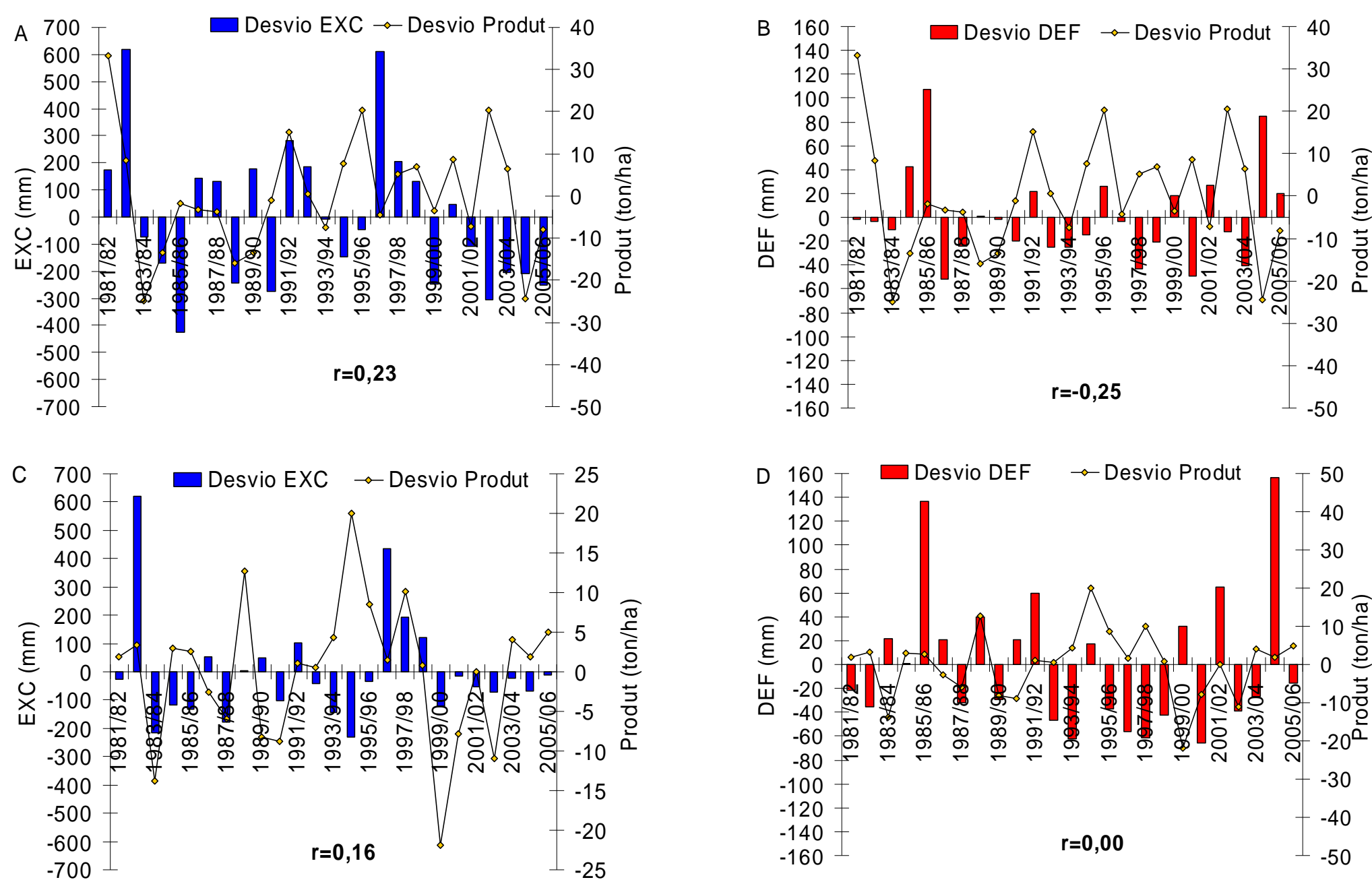

Figura 49 - Desvios de EXC e DEF com os desvios de produtividade da cana-de-açúcar nos municípios de Cambé (A e B) e Mirador (C e D), PR, para o período de 1981/82 a 2005/06.

Org.: Domingues, I.A.S. (2009). 

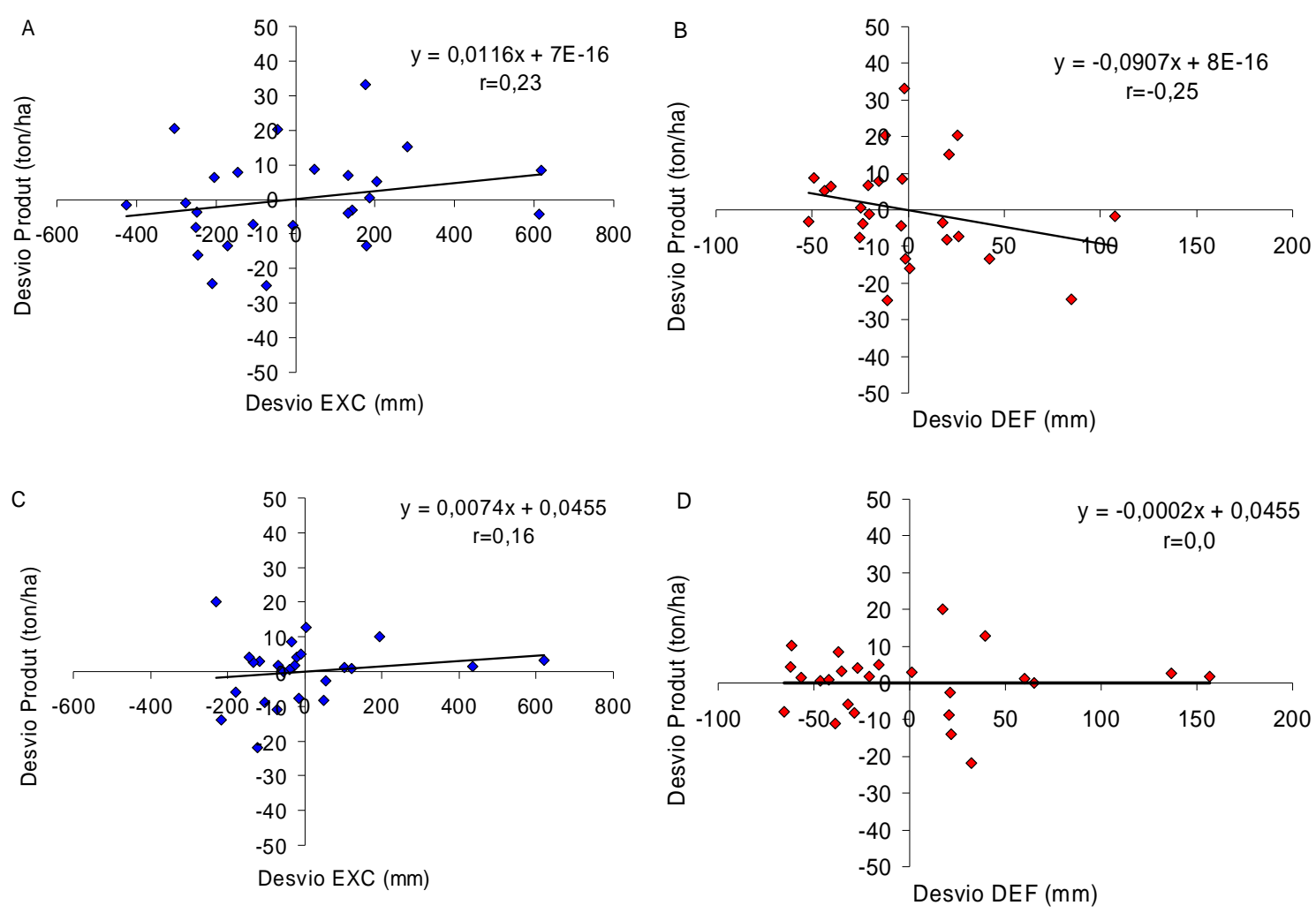

Figura 50 - Dispersão dos desvios de EXC e DEF com os desvios de produtividade da cultura da cana-de-açúcar nos municípios de Cambé (A e B) e Mirador (C e D), PR, para o período de 1981/82 a 2005/06.

Org.: Domingues, I.A.S. (2009).

\subsubsection{2 - Quantificação das variáveis EXC e DEF para os estádios de desenvolvimento vegetativo e maturação}

Outra forma de analise foi usar as variáveis EXC e DEF por estádios fenológicos de desenvolvimento vegetativo (setembro a março) e de maturação (maio a agosto) da cana-de-açúcar. Com esses dados e os de produtividade, efetuaram-se cálculos das médias do período e totais anuais, desvios em relação à média e o coeficiente de correlação entre estes para Cambé e Mirador (Tabela 21).

A média de EXC e DEF, para o estádio de desenvolvimento vegetativo, foram de $470 \mathrm{~mm}$ e $41 \mathrm{~mm}$ em Cambé e de $308,2 \mathrm{~mm}$ e $65,5 \mathrm{~mm}$ em Mirador. Para o estádio de maturação os valores foram de $161,8 \mathrm{~mm}$ e $16,8 \mathrm{~mm}$ no primeiro município e $149,5 \mathrm{~mm}$ e $21,2 \mathrm{~mm}$ para o segundo. Tendo então, Cambé total de EXC mais elevado, por outro lado o total de DEF é maior em Mirador. 
Tabela 21 - Dados de EXC e DEF por estádios de desenvolvimento e maturação, de produtividade, desvios e coeficientes de correlação em Cambé e Mirador, anos agrícolas 1981/82 a 2005/06.

\begin{tabular}{|c|c|c|c|c|c|c|c|c|c|c|c|c|}
\hline Cambé & \multicolumn{6}{|c|}{ Estádio de Desenvolvimento } & \multicolumn{6}{|c|}{ Estádio de Maturação } \\
\hline $\begin{array}{l}\text { Ano } \\
\text { agrícola }\end{array}$ & $\begin{array}{l}\text { EXC } \\
(\mathrm{mm})\end{array}$ & $d_{i}$ EXC & \begin{tabular}{|l|} 
DEF \\
$(\mathrm{mm})$
\end{tabular} & \begin{tabular}{|l}
$d_{i}$ \\
DEF
\end{tabular} & Produt & \begin{tabular}{|l|}
$d_{i}$ \\
Produt \\
\end{tabular} & EXC & $d_{i}$ EXC & DEF & $\begin{array}{l}d_{i} \\
D E F\end{array}$ & \begin{tabular}{|l|}
$\begin{array}{l}\text { Produt } \\
\text { (ton/ha) }\end{array}$ \\
\end{tabular} & \begin{tabular}{|l|}
$d_{i}$ \\
Produt \\
\end{tabular} \\
\hline $1981 / 82$ & 522 & 52 & 54 & 12 & 115,6 & 33,2 & 284,6 & 122,8 & 2,5 & $-14,3$ & 115,6 & 33,2 \\
\hline $1982 / 83$ & 779 & 309 & 28 & -13 & 90,8 & 8,4 & 470,4 & 308,6 & 27,0 & 10,2 & 90,8 & 8,4 \\
\hline $1983 / 84$ & 559 & 89 & 14 & -27 & 57,6 & $-24,8$ & 0,0 & $-161,8$ & 33,2 & 16,5 & 57,6 & $-24,8$ \\
\hline $1984 / 85$ & 369 & -101 & 77 & 35 & 68,9 & $-13,5$ & 92,1 & $-69,7$ & 23,8 & 7,0 & 68,9 & $-13,5$ \\
\hline $1985 / 86$ & 141 & -329 & 151 & 109 & 80,7 & $-1,8$ & 66,4 & $-95,4$ & 15,1 & $-1,7$ & 80,7 & $-1,8$ \\
\hline $1986 / 87$ & 386 & -84 & 5 & -37 & 79,2 & $-3,2$ & 387,3 & 225,5 & 1,4 & $-15,3$ & 79,2 & $-3,2$ \\
\hline $1987 / 88$ & 545 & 74 & 0 & -41 & 78,6 & $-3,8$ & 221,1 & 59,3 & 34,2 & 17,4 & 78,6 & $-3,8$ \\
\hline $1988 / 89$ & 291 & -179 & 51 & 10 & 66,4 & $-16,0$ & 96,3 & $-65,5$ & 8,1 & $-8,7$ & 66,4 & $-16,0$ \\
\hline $1989 / 90$ & 524 & 54 & 57 & 15 & 68,9 & $-13,5$ & 286,5 & 124,8 & 0,0 & $-16,8$ & 68,9 & $-13,5$ \\
\hline $1990 / 91$ & 286 & -184 & 15 & -26 & 81,3 & $-1,1$ & 70,3 & $-91,5$ & 22,8 & 6,0 & 81,3 & $-1,1$ \\
\hline $1991 / 92$ & 687 & 217 & 75 & 33 & 97,6 & 15,2 & 226,8 & 65,1 & 4,5 & $-12,2$ & 97,6 & 15,2 \\
\hline $1992 / 93$ & 684 & 214 & 27 & -15 & 83,0 & 0,6 & 133,0 & $-28,8$ & 6,6 & $-10,2$ & 83,0 & 0,6 \\
\hline $1993 / 94$ & 428 & -42 & 15 & -26 & 74,9 & $-7,5$ & 198,0 & 36,2 & 17,7 & 1,0 & 74,9 & $-7,5$ \\
\hline $1994 / 95$ & 464 & -6 & 31 & -10 & 90,2 & 7,8 & 22,2 & $-139,6$ & 11,9 & $-4,9$ & 90,2 & 7,8 \\
\hline $1995 / 96$ & 586 & 116 & 19 & -22 & 102,7 & 20,3 & 0,0 & $-161,8$ & 64,7 & 48,0 & 102,7 & 20,3 \\
\hline $1996 / 97$ & 891 & 421 & 53 & 11 & 78,0 & $-4,4$ & 353,1 & 191,3 & 2,0 & $-14,7$ & 78,0 & $-4,4$ \\
\hline $1997 / 98$ & 738 & 268 & 13 & -28 & 87,6 & 5,2 & 97,8 & $-64,0$ & 1,3 & $-15,4$ & 87,6 & 5,2 \\
\hline $1998 / 99$ & 577 & 107 & 23 & -18 & 89,2 & 6,8 & 187,3 & 25,6 & 14,1 & $-2,7$ & 89,2 & 6,8 \\
\hline $1999 / 00$ & 254 & -216 & 73 & 32 & 78,8 & $-3,6$ & 130,1 & $-31,7$ & 2,9 & $-13,9$ & 78,8 & $-3,6$ \\
\hline $2000 / 01$ & 480 & 10 & 8 & -33 & 91,1 & 8,7 & 200,1 & 38,3 & 0,9 & $-15,8$ & 91,1 & 8,7 \\
\hline $2001 / 02$ & 325 & -145 & 72 & 31 & 75,2 & $-7,2$ & 199,2 & 37,4 & 12,6 & $-4,2$ & 75,2 & $-7,2$ \\
\hline $2002 / 03$ & 313 & -157 & 42 & 1 & 102,8 & 20,4 & 15,2 & $-146,6$ & 4,1 & $-12,6$ & 102,8 & 20,4 \\
\hline $2003 / 04$ & 121 & -349 & 3 & -38 & 88,8 & 6,4 & 306,9 & 145,1 & 14,2 & $-2,6$ & 88,8 & 6,4 \\
\hline $2004 / 05$ & 423 & -47 & 117 & 76 & 58,0 & $-24,4$ & 0,0 & $-161,8$ & 25,6 & 8,9 & 58,0 & $-24,4$ \\
\hline $2005 / 06$ & 380 & -90 & 10 & -31 & 74,3 & $-8,1$ & 0,0 & $-161,8$ & 67,9 & 51,1 & 74,3 & $-8,1$ \\
\hline Média & 470 & & 41 & & 82,4 & & 161,8 & & 16,8 & & 82,4 & \\
\hline $\mathbf{r}$ & & 0,17 & & $-0,19$ & & & & 0,20 & & $-0,13$ & & \\
\hline \multicolumn{13}{|l|}{ Mirador } \\
\hline $1981 / 82$ & 239 , & $-68,9$ & 57,8 & $-7,8$ & 78,1 & 1,9 & 192,0 & 42,6 & 7,6 & $-13,6$ & 78,1 & 1,9 \\
\hline$/ 83$ & 664, & 356,5 & 12,2 & $-53,3$ & 79,5 & 3,3 & 413,8 & 264,3 & 39,0 & 17,8 & 79,5 & 3,3 \\
\hline $1983 / 84$ & 242 & $-65,8$ & 43,4 & $-22,2$ & 62,4 & $-13,8$ & 0,0 & $-149,5$ & 65,0 & 43,8 & 62,4 & $-13,8$ \\
\hline $1984 / 85$ & 286, & $-22,1$ & 80,3 & 14,8 & 79,1 & 2,9 & 54,1 & $-95,3$ & 7,4 & $-13,8$ & 79,1 & 2,9 \\
\hline $1985 / 86$ & 170 , & $-138,2$ & 202,8 & 137,3 & 78,8 & 2,6 & 155,3 & 5,8 & 20,5 & $-0,7$ & 78,8 & 2,6 \\
\hline $1986 / 87$ & 153 & $-154,3$ & 100,1 & 34,6 & 73,6 & $-2,6$ & 358,6 & 209,1 & 7,6 & $-13,7$ & 73,6 & $-2,6$ \\
\hline 1987/88 & 206 , & $-102,3$ & 11,7 & $-53,8$ & 70,2 & $-6,0$ & 73,6 & $-75,8$ & 42,7 & 21,5 & 70,2 & $-6,0$ \\
\hline $1988 / 89$ & 257, & $-50,7$ & 116,7 & 51,1 & 89,0 & 12,8 & 204,5 & 55,1 & 9,8 & $-11,4$ & 89,0 & 12,8 \\
\hline $1989 / 90$ & 243 & $-65,1$ & 57,7 & $-7,8$ & 68,0 & $-8,2$ & 264,2 & 114,8 & 0,0 & $-21,2$ & 68,0 & $-8,2$ \\
\hline $1990 / 91$ & 309, & 1,2 & 64,4 & $-1,1$ & 67,4 & $-8,8$ & 45,0 & $-104,5$ & 43,1 & 21,9 & 67,4 & $-8,8$ \\
\hline $1991 / 92$ & 272 & $-35,6$ & 141,3 & 75,8 & 77,3 & 1,1 & 288,6 & 139,1 & 5,2 & $-16,0$ & 77,3 & 1,1 \\
\hline $1992 / 93$ & 381 , & 73,0 & 33,8 & $-31,7$ & 76,8 & 0,6 & 36,4 & $-113,1$ & 6,5 & $-14,8$ & 76,8 & 0,6 \\
\hline $1993 / 94$ & 136 , & $-171,5$ & 8,2 & $-57,3$ & 80,5 & 4,3 & 177,5 & 28,0 & 16,1 & $-5,1$ & 80,5 & 4,3 \\
\hline $1994 / 95$ & 228 & $-80,2$ & 56,6 & $-9,0$ & 96,2 & 20,0 & 0,0 & \begin{tabular}{|l|}
$-149,5$ \\
\end{tabular} & 47,2 & 26,0 & 96,2 & 20,0 \\
\hline $1995 / 96$ & 386 , & 78,2 & 17,0 & $-48,6$ & 84,7 & 8,5 & 37,6 & \begin{tabular}{|l|}
$-111,9$ \\
\end{tabular} & 32,8 & 11,5 & 84,7 & 8,5 \\
\hline $1996 / 97$ & 624, & 316,0 & 19,2 & $-46,3$ & 77,7 & 1,5 & 267,7 & 118,3 & 11,1 & $-10,1$ & 77,7 & 1,5 \\
\hline $1997 / 98$ & 589 , & 281,3 & 20,6 & $-44,9$ & 86,3 & 10,1 & 62,1 & $-87,3$ & 4,5 & $-16,7$ & 86,3 & 10,1 \\
\hline $1998 / 99$ & 407, & 98,7 & 27,6 & $-38,0$ & 77,1 & 0,9 & 172,7 & 23,2 & 17,2 & $-4,0$ & 77,1 & 0,9 \\
\hline $1999 / 00$ & 217 & $-91,1$ & 113,1 & 47,5 & 54,3 & $-21,9$ & 119,2 & $-30,3$ & 6,1 & $-15,1$ & 54,3 & $-21,9$ \\
\hline $2000 / 01$ & 291, & $-17,0$ & 17,2 & $-48,3$ & 68,4 & $-7,8$ & 150,8 & 1,3 & 4,0 & $-17,3$ & 68,4 & $-7,8$ \\
\hline $2001 / 02$ & 181, & $-127,3$ & 132,7 & 67,2 & 76,2 & 0,0 & 221,9 & 72,5 & 19,0 & $-2,3$ & 76,2 & 0,0 \\
\hline $2002 / 03$ & 351 , & 43,7 & 47,1 & $-18,4$ & 65,2 & $-11,0$ & 34,2 & $-115,3$ & 0,9 & $-20,3$ & 65,2 & $-11,0$ \\
\hline $2003 / 04$ & 29,5 & $-278,8$ & 42,8 & $-22,7$ & 80,2 & 4,0 & 406,6 & 257,2 & 16,9 & $-4,3$ & 80,2 & 4,0 \\
\hline $2004 / 05$ & 389, & 81,2 & 185,0 & 119,5 & 78,0 & 1,8 & 0,0 & $-149,5$ & 58,6 & 37,4 & 78,0 & 1,8 \\
\hline $2005 / 06$ & 447, & 139,0 & 29,0 & $-36,6$ & 81,2 & 5,0 & 0,0 & \begin{tabular}{|l|}
$-149,5$ \\
\end{tabular} & 41,9 & 20,7 & 81,2 & 5,0 \\
\hline Média & 308 , & & 65,5 & & 76,2 & & 149,5 & & 21,2 & & 76,2 & \\
\hline $\mathbf{R}$ & & 0,17 & & $-0,03$ & & & & 0,032 & & 0,087 & & \\
\hline
\end{tabular}

Org.: Domingues, I.A.S. (2009). 
Quanto ao estádio de desenvolvimento, os maiores desvios positivos de EXC, nos dois municípios, ocorreram nos anos agrícolas de 1982/83 e 1996/97, com totais acima de $300 \mathrm{~mm}$ e desvios de produtividade também acima da média; entretanto, em relação aos anos imediatamente anteriores, houve redução significativa (Figura 51, A e C). Os desvios positivos de DEF ocorreram em 1985/86 e 2003/04, com totais de $109 \mathrm{~mm}$ e $76 \mathrm{~mm}$ em Cambé e de $137,3 \mathrm{~mm}$ e $119,5 \mathrm{~mm}$ em Mirador (Figura $51, A$ e C).

Para o estádio de maturação, as variáveis hídricas, EXC e DEF, apresentaram o seguinte comportamento: maiores desvios positivos de EXC ocorreram nos anos agrícolas de 1982/83 e 1986/87, com totais de 308,6mm e 225,5mm em Cambé (Figura 51 B), e em 1982/83 e 2003/04, com totais de $264,3 \mathrm{~mm}$ e $257,2 \mathrm{~mm}$, respectivamente, em Mirador (Figura $51 \mathrm{D}$ ). Para a DEF, os maiores desvios ocorreram nos anos de 1995/96 e 2005/06 em Cambé, com valores $48,0 \mathrm{~mm}$ e $51,1 \mathrm{~mm}$, e desvio positivo de produtividade no primeiro ano agrícola e desvio na média para o segundo (Figura 51 B). Em Mirador houve desvio positivo de DEF nos anos agrícolas de 1983/84 (43,8mm) e 2004/05 (37,4mm), com desvio negativo de produtividade para o primeiro e desvio positivo para o segundo (Figura $51 \mathrm{D})$.

A fim de verificar a correlação dessas variáveis hídricas com a produtividade por estádio fenológico, efetuaram-se os cálculos dos coeficientes de correlação (Figura 52).

Para o estádio de desenvolvimento vegetativo, o coeficiente de correlação entre EXC e produtividade foi de $r=0,17$, tanto em Cambé (Figura $52 \mathrm{~A}$ ) quanto em Mirador (Figura $52 \mathrm{~B}$ ). O sinal positivo indica que a produtividade aumenta conforme aumenta o total de EXC. Ainda nesse estádio, a correlação entre DEF e produtividade foi de $r=-0,19$ em Cambé e de $r=-0,03$ em Mirador. $O$ sinal negativo indica que, conforme aumenta a deficiência hídrica, a produtividade diminui.

No estádio de maturação, o coeficiente de correlação entre EXC e produtividade foi de $r=-0,20$ em Cambé e de $r=0,032$ em Mirador, enquanto que para a DEF e produtividade o coeficiente de correlação foi de $r=-0,13$ em Cambé e de $r=0,09$ em Mirador. 

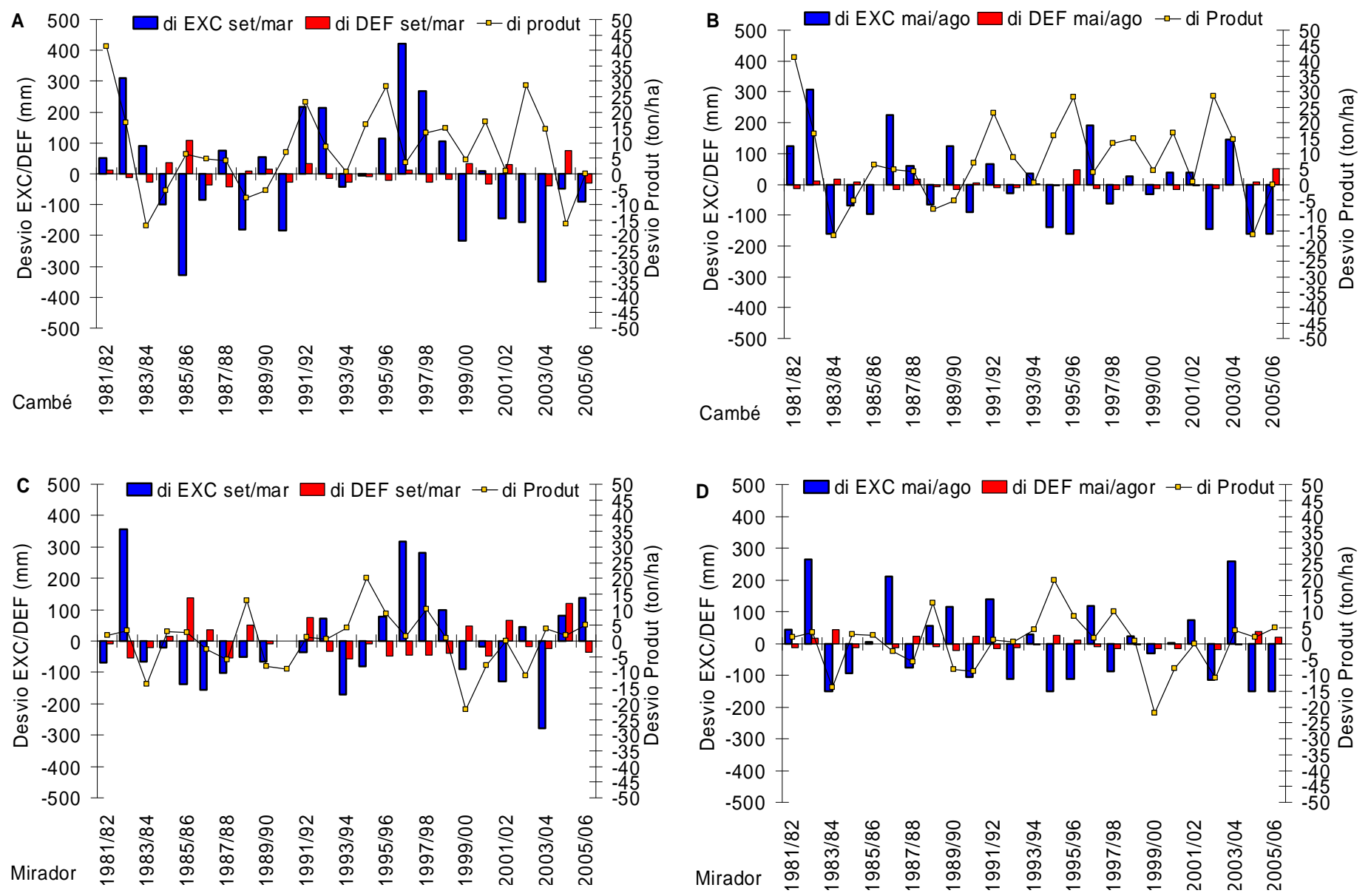

Figura 51 - Desvios de EXC e DEF com desvios de produtividade da cana-de-açúcar de Cambé e Mirador, PR, período de 1981/82 a 2005/06. Org.: Domingues, I.A.S. (2009). 

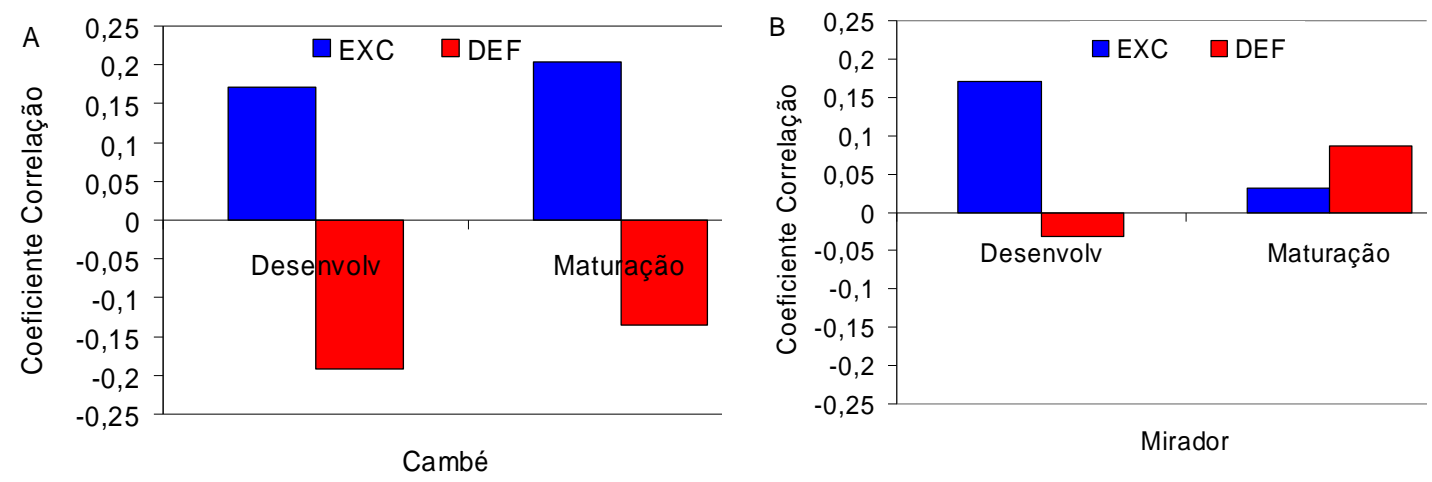

Figura 52 - Coeficiente de correlação das variáveis EXC e DEF com a produtividade da cana-deaçúcar nos estádios de desenvolvimento e maturação nos municípios de (A) Cambé e (B) Mirador, período de1981/82 a 2005/06.

Org.: Domingues, I.A.S. (2009).

Para melhor compreensão visual de existência de correlação entre essas variáveis elaboraram-se diagramas de dispersão ou correlação (Figura 53).

Em todos os diagramas as nuvens de pontos apresentam-se dispersas, não oferecendo uma imagem definida (Figura 53). Essa característica indica correlação fraca, sendo os coeficientes de correlação para EXC e DEF e produtividade no estádio de desenvolvimento de $r=0,17$ e $-0,19$ e de $r=0,20$ e $r=-0,13$ no estádio de maturação em Cambé (Figura 53 A, A1, B, B1). Em Mirador os valores dos coeficientes foram de $r=0,17, r=-0,03, r=0,3$ e $r=0,09$ respectivamente (Figura 53 C, C1, D e D1).

Todas as variáveis até o momento utilizadas, sejam estas dados anuais de chuva e temperatura, dados anuais de EXC e DEF, ou sejam dados por estádio fenológico de EXC e DEF, apresentaram correlação com os dados de produtividade considerada fraca. Isso porque valores próximos de zero significam que existe pouco relacionamento entre as variáveis.

Em face desses resultados, optou-se por determinar os dados das variáveis hídricas por meio do BH Sequencial decendial, e então correlacioná-las com os dados de produtividade da cultura da cana-de-açúcar. 

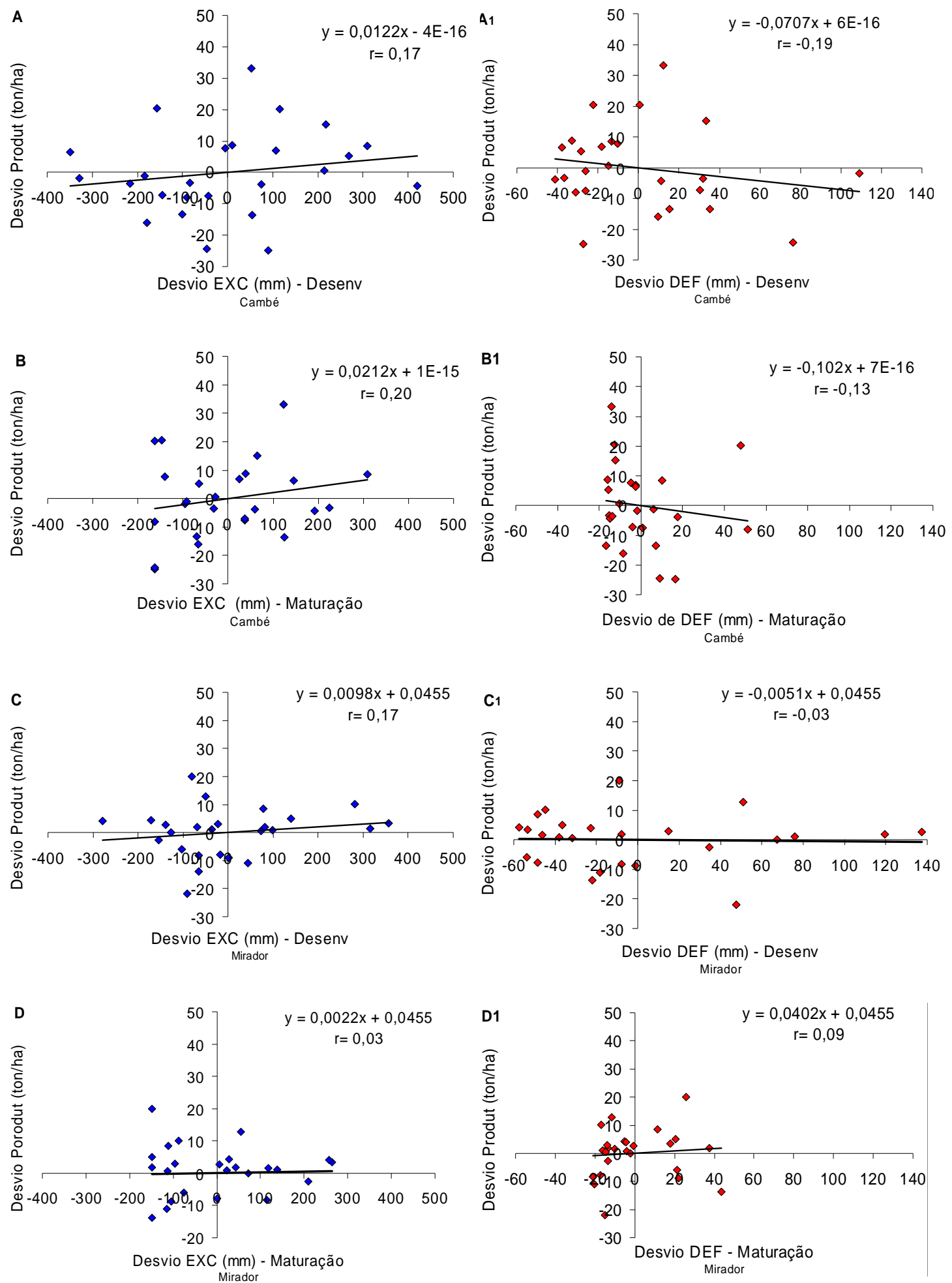

Figura 53 - Diagrama de dispersão das variáveis hídricas e a produtividade da cana-de-açúcar para os municípios de Cambé e Mirador, período 1981/82 a 2005/06.

Org.: Domingues, I.A.S. (2009). 


\subsection{3 - Balanço Hídrico Sequencial e a produtividade da cana-de-açúcar}

Esse tipo de $\mathrm{BH}$ pode ser utilizado também para o acompanhamento de água no solo para um curto período de tempo ou ao longo de vários anos e sua comparação com um ano médio (normal).

Os dados de clima utilizados na elaboração desse $\mathrm{BH}$ foram os mesmos dados de clima do $\mathrm{BH}$ Normal, embora na escala de tempo de decêndios, e os mesmos dados de produtividade para a mesma série temporal, bem como os mesmo procedimentos matemáticos.

Com os dados decendiais das variáveis de EXC, de DEF e de produtividade, elaboraram-se as médias do período, seus totais anuais, seguidos de seus desvios em relação à média, bem como a determinação do coeficiente de correlação das variáveis hídricas em relação à produtividade da cana-de-açúcar nos municípios de Cambé e Mirador. Aplicou-se também o teste $t$ de Student $\left(t_{n-1}\right)$, com a finalidade de verificar se a correlação entre as variáveis foi significante (Tabela 22).

No município de Cambé, as médias das variáveis hídricas de EXC e DEF foram de $640,3 \mathrm{~mm}$ e $105,1 \mathrm{~mm}$ e para a variável produtividade a média foi de 82,4 ton/ha (Tabela 22).

Análise dos desvios em relação à média do período:

Os maiores desvios das variáveis hídricas e produtividade ocorreram nos anos agrícolas de 1982/83, 1985/86, 1996/97 e 2004/05 (Figura 54, A,$A_{2}$ ).

Os valores máximos de EXC ocorreram nos anos agrícolas de 1982/83 e 1996/97. Para o primeiro ano o EXC foi de 93,7\% acima da média e a produtividade de 10,2\% também acima da média (Figura 54, $\mathrm{A}_{1}$ ). No segundo ano o EXC foi de 103,9\% acima da média e a produtividade 5,3\% abaixo da média. Os valores máximos de DEF ocorreram nos anos agrícolas de 1985/86 e 2004/05. Estes estiveram acima da média em 137,4\% e 112,4\%, com produtividade abaixo da média em 2,06\% e 29,6\%, respectivamente (Figura 54, $\mathrm{A}_{2}$ ). 
Tabela 22 - Dados de EXC e DEF, produtividade, seus desvios em relação à média $\left(\mathrm{d}_{\mathrm{i}}\right)$, coeficientes de correlação e teste t de Student $(\mathrm{t}(\mathrm{n}-1))$ para os anos agrícolas de 1981/82 a 2005/06 dos municípios de Cambé e Mirador, PR.

\begin{tabular}{|c|c|c|c|c|c|c|c|c|c|c|c|c|}
\hline \multirow[b]{2}{*}{$\begin{array}{l}\text { Ano } \\
\text { agrícola }\end{array}$} & \multicolumn{6}{|c|}{ Cambé } & \multicolumn{6}{|c|}{ Mirador } \\
\hline & $\begin{array}{l}\text { EXC } \\
(\mathrm{mm})\end{array}$ & $d_{i}$ & \begin{tabular}{|l|} 
DEF \\
$(\mathrm{mm})$
\end{tabular} & $d_{i}$ & Produt & $d_{i}$ & $\begin{array}{l}\begin{array}{l}\text { EXC } \\
(\mathrm{mm})\end{array} \\
\end{array}$ & $d_{i}$ & \begin{tabular}{|l|} 
DEF \\
$(\mathrm{mm})$
\end{tabular} & $d_{i}$ & \begin{tabular}{|l|}
$\begin{array}{l}\text { Produt } \\
\text { (ton/ha) }\end{array}$ \\
\end{tabular} & $d_{i}$ \\
\hline $1981 / 82$ & 832,1 & 191,8 & 99,9 & $-5,3$ & 115,6 & 33,2 & 504,7 & $-19,2$ & 114,3 & $-23,4$ & 78,1 & 1,9 \\
\hline $1982 / 83$ & 1240,9 & 600,5 & 4,1 & $-31,0$ & 90,8 & 8,4 & 1101,9 & 578,0 & 93,8 & $-44,0$ & 79,5 & 3,3 \\
\hline $1983 / 84$ & 598,4 & $-41,9$ & 139,2 & 34,1 & 57,6 & $-24,8$ & 337,3 & $-186,7$ & 199,8 & 62,1 & 62,4 & $-13,8$ \\
\hline $1984 / 85$ & 66,7 & $-73,6$ & 89,9 & $-15,2$ & 68,9 & $-13,5$ & 546,8 & 22,9 & 85,6 & $-52,1$ & 79,1 & 2,9 \\
\hline $1985 / 86$ & 185,2 & $-455,1$ & $\mid 249,5$ & 144,4 & 80,7 & $-1,8$ & 137,7 & $-386,2$ & 239,4 & $\mid 101,7$ & 78,8 & 2,6 \\
\hline $1986 / 87$ & 805,5 & 165,2 & 25,9 & $-79,2$ & 79,2 & $-3,2$ & 451,4 & $-72,6$ & 280,9 & 143,2 & 73,6 & $-2,6$ \\
\hline $1987 / 88$ & 850,2 & 209,8 & 66,7 & $-38,4$ & 78,6 & $-3,8$ & 441,9 & $-82,0$ & 125,8 & $-11,9$ & 70,2 & $-6,0$ \\
\hline $1988 / 89$ & 400,4 & $-239,9$ & 148,0 & 42,9 & 66,4 & $-16,0$ & 0 & $-11,9$ & 157,4 & 19,7 & 9,0 & 12,8 \\
\hline $1989 / 90$ & 867,5 & 227,2 & 129,3 & 24,2 & 68,9 & $-13,5$ & 599,2 & 75,3 & 118,9 & $-18,9$ & 8,0 & $-8,2$ \\
\hline 19 & 0,1 & $-250,2$ & 75 & $-29,9$ & 3 & 1 & 3 & 6 & 121,3 & 6,4 & 4 & 8 \\
\hline 19 & 379,7 & $-260,7$ & 79,2 & $-26,0$ & 97,6 & 15,2 & 685,8 & 161,9 & 194,0 & 56,2 & 7,3 & 1,1 \\
\hline $1992 / 93$ & 817,3 & 177,0 & 63,7 & $-41,4$ & 83,0 & 0,6 & 432,0 & $-91,9$ & 59,7 & $-78,0$ & 76,8 & 0,6 \\
\hline $1993 / 94$ & 656,6 & 16,2 & 89,9 & $-15,2$ & 74,9 & $-7,5$ & 492,2 & $-31,8$ & 60,6 & $-77,1$ & 80,5 & 4,3 \\
\hline 199 & 581,1 & $-59,3$ & 105,4 & 0,3 & 90,2 & 7,8 & ,3 & $-212,6$ & 179,9 & 42,2 &, 2 & 20,0 \\
\hline 1 & 3 & 1 & 163 & 0 & 7 & 3 & 535,6 & 11,7 & 104,4 & $-0,0$ & 84,1 & 8,5 \\
\hline $1996 / 97$ & 1305,9 & 665,6 & 123,7 & 18,5 & 78,0 & $-4,4$ & 992,5 & 468,6 & 122,7 & $-15,0$ & 77,7 & 1,5 \\
\hline $1997 / 98$ & 839,1 & 198,8 & 50,4 & $-54,8$ & 87,6 & 5,2 & 765,9 & 241,9 & 71,4 & $-66,3$ & 86,3 & 10,1 \\
\hline $1998 / 99$ & 708,5 & 68,1 & 139,8 & 34,7 & 89,2 & 6,8 & 651,6 & 127,7 & 109,2 & $-28,5$ & 77,1 & 0,9 \\
\hline $1999 / 00$ & 420,2 & 220,1 & 68,5 & $-36,6$ & 78,8 & $-3,6$ & 380,5 & $-143,4$ & 186,1 & 48,4 & 54,3 & $-21,9$ \\
\hline $2000 / 01$ & 697,5 & 57,2 & 39,8 & $-65,4$ & 91,1 & 8,7 & 499,8 & $-24,1$ & 65,1 & $-72,6$ & 68,4 & $-7,8$ \\
\hline $2001 / 02$ & 606,0 & $-34,4$ & 104,4 & $-0,7$ & 75,2 & $-7,2$ & 556,8 & 32,9 & 192,9 & 55,2 & 76,2 & 0,0 \\
\hline $2002 / 03$ & 348,9 & $-291,4$ & 107,1 & 2,0 & 102,8 & 20,4 & 476,3 & $-47,6$ & 95,1 & $-42,6$ & 65,2 & $-11,0$ \\
\hline $2003 / 04$ & 431,5 & $-208,9$ & 63,6 & $-41,5$ & 88,8 & 6,4 & 493,0 & $-30,9$ & 50,3 & $-87,4$ & 30,2 & 4,0 \\
\hline $2004 / 05$ & 448,0 & $-192,3$ & 223,3 & 118,2 & 58,0 & $-24,4$ & 298,9 & $-225,0$ & 223,2 & 85,5 & 78,0 & 1,8 \\
\hline $2005 / 06$ & 402,7 & $-237,7$ & 107,5 & 2,4 & 74,3 & $-8,1$ & 495,7 & $-28,2$ & 161,2 & 23,5 & 81,2 & 5,0 \\
\hline Média & 640,3 & & 105,1 & & 82,4 & & 523,9 & & 137,7 & & 76,2 & \\
\hline$r$ & & 0,1 & & $-0,3$ & & & & 0,2 & & $-0,1$ & & \\
\hline$t(n-1)$ & & 0,5 & & 1,5 & & & & 1,0 & & 0,5 & & \\
\hline
\end{tabular}

Org.: Domingues, I.A.S. (2009).

Em Mirador as médias do EXC, DEF e produtividade foram de $523,9 \mathrm{~mm}$, $137,7 \mathrm{~mm}$ e 76,2 ton/ha, respectivamente (Tabela 22 ). 


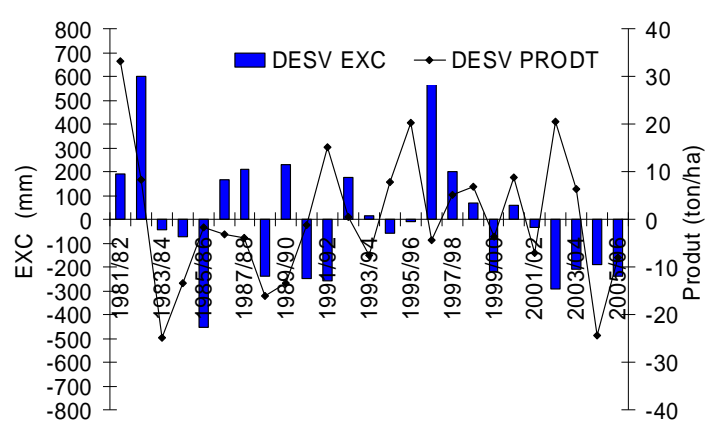

$A_{1}$
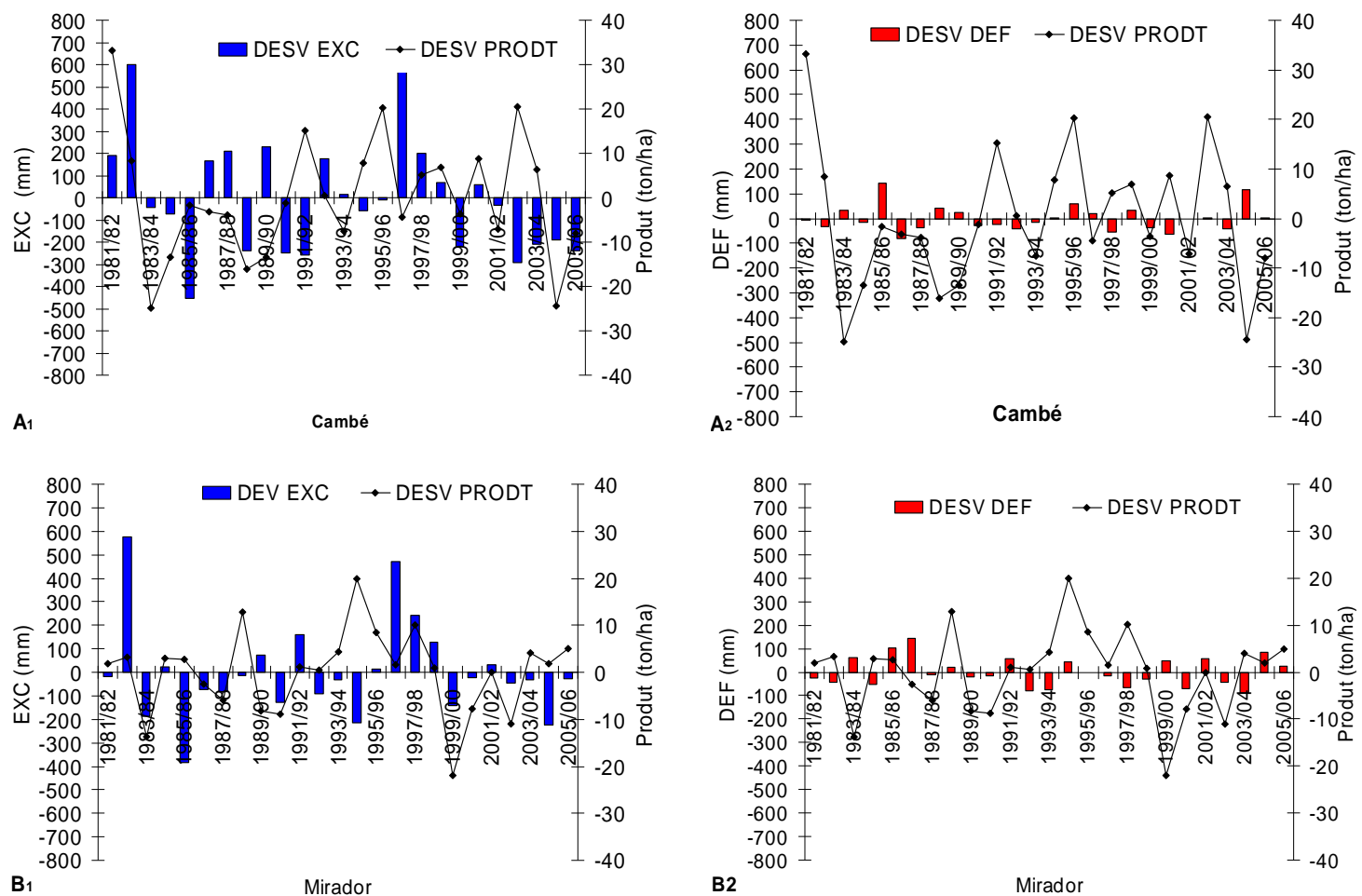

Figura 54 - Desvios de EXC/DEF e produtividade da cultura da cana-de-açúcar nos municípios de Cambé e Mirador, anos agrícolas 1981/82 a 2005/06.

Org.: Domingues, I.A.S. (2009).

Os maiores desvios ocorreram nos anos agrícolas de 1982/83, 1985/86, 1986/87 e 1996/97 (Figura 54, B1 e B2).

Nesse município os valores máximos de EXC aconteceram no ano de 1982/83, 1996/97, com 110,3\% e 89,4\% acima da média do período, e suas respectivas produtividades com percentuais de 4,3\% e 1,96 também acima da média (Figura 54, B1). As maiores DEF ocorreram nos anos de 1985/86 e em 1986/87, com aumento de $73,9 \%$ e $104,0 \%$ e produtividade de $3,4 \%$ acima da média no primeiro ano e 3,4\% abaixo da média no segundo ano (Figura 54, B2).

Quanto à correlação dos totais anuais das variáveis EXC/DEF e Produtividade, obteve-se:

Para o município de Cambé a correlação entre EXC e produtividade foi considerada fraca, com coeficiente de correlação positivo de $r=0,1$, (Figura $55 A_{1}$ ), enquanto que para a DEF e produtividade a correlação foi moderada, com 
coeficiente de correlação negativo de $r=-0,3$. O sinal positivo do primeiro coeficiente indica que, havendo aumento de EXC, há aumento de produtividade. $O$ sinal negativo do segundo coeficiente indica que, quando a variável DEF diminui, a variável produtividade tende a aumentar. O gráfico de dispersão, por apresentar distribuição da nuvem de pontos dispersa, vem corroborar o grau de relacionamento dessas variáveis (Figura 55, $\mathrm{A}_{1} \mathrm{~A}_{2}$ ). Esse grau de relacionamento, por meio do teste $t$ de Student, a nível de significância de 0,10 (10\%), mostrou que existe correlação significativa apenas entre DEF e produtividade.

Em Mirador as correlações entre as variáveis EXC/DEF e produtividade foram consideradas fracas (Figura 55, $B_{1}$ ), com coeficiente de correlação positivo de $r=0,2$ para EXC e produtividade e negativo de $r=-0,1$ para DEF e produtividade (Figura 55, $B_{2}$ ). Confirmou-se pelo teste $t$ de Student a nível de $10 \%$ que a correlação entre as EXC/DEF e produtividade não é significativa (Tabela 22). O gráfico de dispersão confirma essa condição por apresentar a nuvem de pontos bastante dispersa (Figura $\left.55, B_{1} B_{2}\right)$.
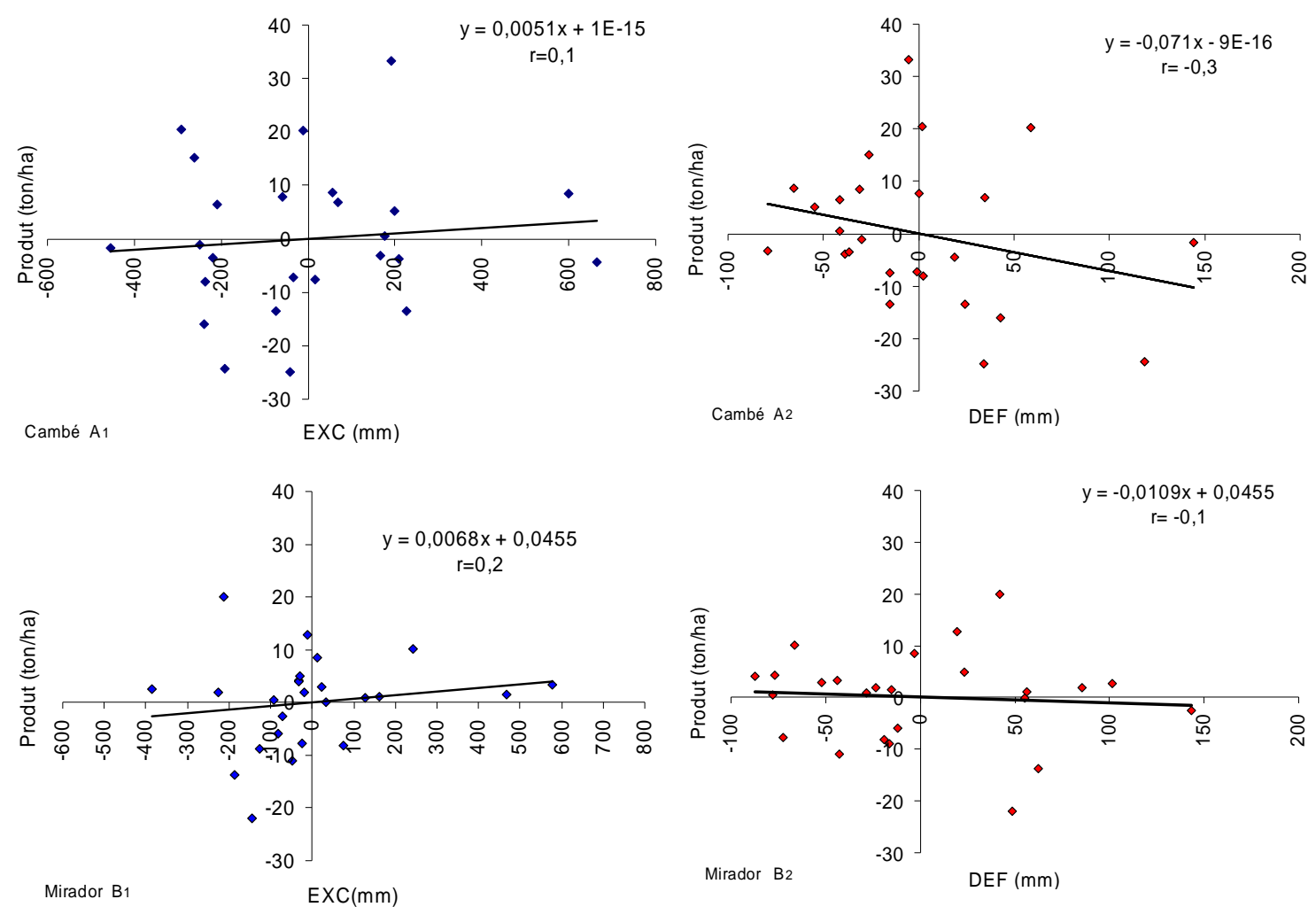

Figura 55 - Dispersão entre EXC/DEF e produtividade para a cultura da cana-de-açúcar nos municípios de Cambé $\left(A_{1}\right.$ e $\left.A_{2}\right)$ e Mirador ( $B_{1}$ e $\left.B_{2}\right)$, anos agrícolas de 1981/82 a 2005/206.

Org.: Domingues, I.A.S. (2009). 


\subsubsection{1 - Análise do extrato do BH Sequencial para as variáveis EXC e DEF}

Além de apresentar os dados numéricos das variáveis estudadas, objetivouse, por meio de gráficos do extrato do $\mathrm{BH}$ Sequencial, ilustrar o comportamento hídrico das variáveis EXC e DEF nos anos de máximos totais. bem como a sua evolução temporal e sua respectiva produtividade (Figura 56).

Em Cambé a evolução temporal das variáveis se comportou da seguinte forma:

Para os anos agrícolas com os máximos EXC: no ano agrícola de 1982/83 só não houve EXC nos três decêndios de setembro, no terceiro de abril, no primeiro e segundo de maio e no terceiro de agosto. Os maiores totais de EXC, em torno de $100 \mathrm{~mm}$, ocorreram no primeiro decêndio de dezembro e no segundo de julho. Nessas condições a produtividade esteve acima da média (Figura 56, A1).

No ano agrícola de 1996/97 não houve EXC no primeiro decênio de outubro, no terceiro de fevereiro, nos três decêndios de março, no segundo e terceiro de abril, no primeiro e segundo de maio e no segundo de julho e de agosto. Os totais de EXC, acima de 100,0mm, ocorreram nos seguintes decêndios: segundo de novembro, com 133,0mm, terceiro de janeiro, com 218,0 mm, segundo de fevereiro, com 177,0mm, e primeiro de junho, com 182,0mm. Embora esse ano tivesse o maior EXC do período de tempo analisado, a DEF esteve também acima da média. Para essas condições, a produtividade esteve abaixo da média (Figura 56, $A_{2}$ ).

Anos agrícolas com máxima DEF: no ano de 1985/86 predominou DEF a partir do primeiro decêndio de setembro até o segundo de janeiro, variando até $29,0 \mathrm{~mm}$. Para os demais decêndios com DEF, estes atingiram até $11,0 \mathrm{~mm}$. Nessa situação, a produtividade ficou 1,7 ton/ha abaixo da média (Figura 56, $B_{1}$ ). No ano de 2004/05 houve uma DEF ininterrupta, que se iniciou no primeiro decêndio de fevereiro e se prolongou até agosto. A produtividade desse ano esteve 24,4 ton/ha abaixo da média do período (Figura 56, $\mathrm{B}_{2}$ ). 

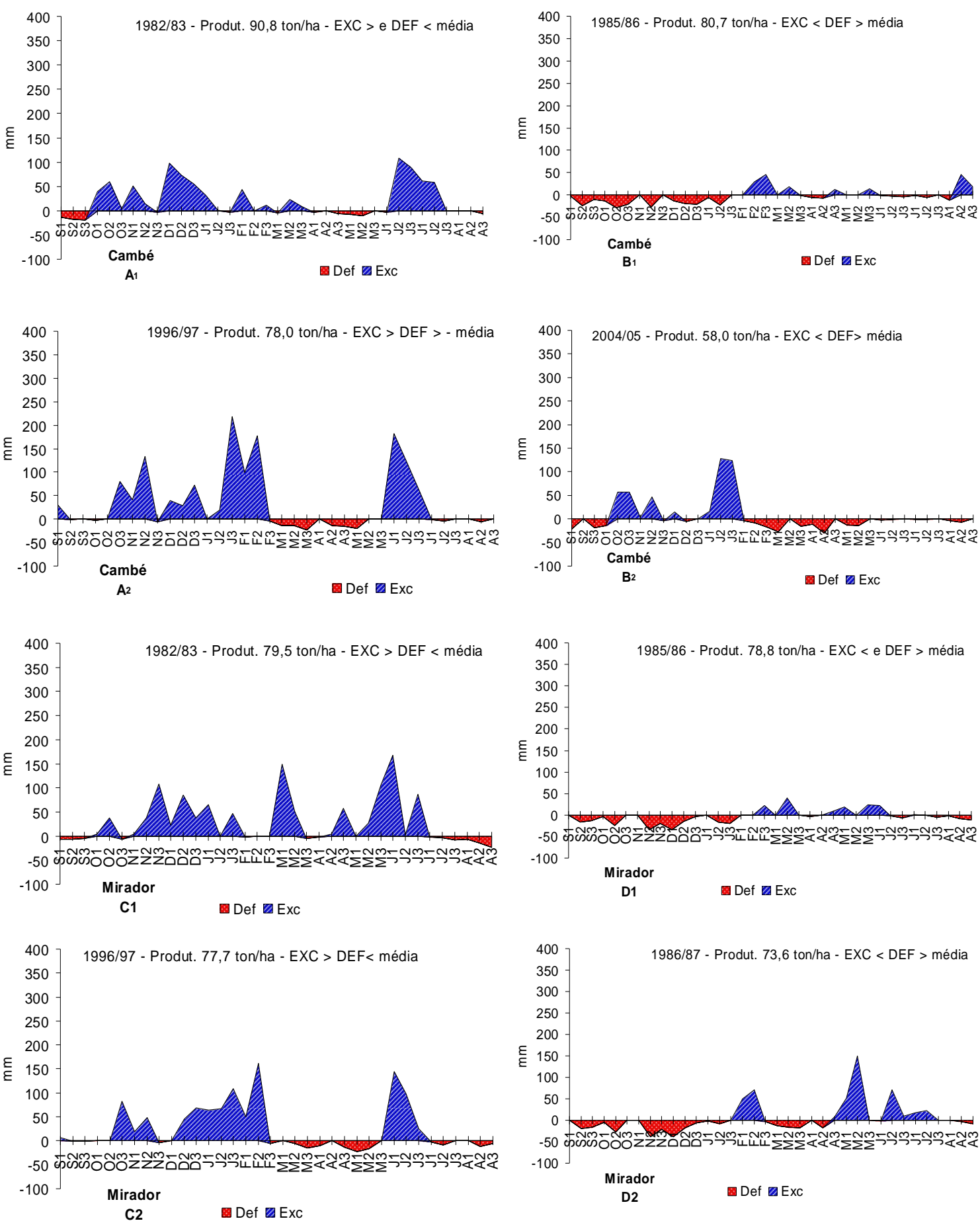

Figura 56 - Extrato do BH Sequencial dos anos agrícolas com desvios máximos de EXC e DEF hídrica e suas respectivas produtividades para Cambé (máx. EXC: $A_{1}, A_{2}$, máx. DEF: $B_{1}$ e $B_{2}$ ) e Mirador (Máx. EXC: $\mathrm{C}_{1}, \mathrm{C}_{2}$, máx. DEF: $\mathrm{D}_{1}$ e $\mathrm{D}_{2}$ ), PR.

Org.: Domingues, I.A.S. (2009). 
No município de Mirador a evolução temporal por decêndios dos anos com máximos EXC e DEF se comportou da seguinte forma:

Para o EXC - no ano agrícola de 1982/83, na maioria dos meses, com exceção de setembro, julho e agosto, houve EXC. Os máximos totais dessa variável ocorreram nos seguintes decêndios: terceiro de novembro, com 108,6mm, segundo de dezembro, com $84,5 \mathrm{~mm}$, primeiro de março, com 141,7mm, primeiro e terceiro de junho, com $166,9 \mathrm{~mm}$ e $87,0 \mathrm{~mm}$. Nesse cenário, a produtividade esteve acima da média, com 3,3 ton/ha (Figura 56, $\mathrm{C}_{1}$ );

Em 1996/97 os decêndios com EXC foram: primeiro de setembro, com $6,0 \mathrm{~mm}$, terceiro de outubro, com $82,5 \mathrm{~mm}$, primeiro e segundo de novembro, com $18,8 \mathrm{~mm}$ e $49,2 \mathrm{~mm}$, segundo de dezembro até o segundo de fevereiro, com totais entre 45,2mm e 162,3mm, e os três decêndios de junho, com 145,2mm, 97,8mm e $25,9 \mathrm{~mm}$, respectivamente (Figura 56, $\mathrm{C}_{2}$ ).

Para a DEF - ano agrícola de 1985/86 ocorreu DEF de forma sequencial de setembro a janeiro, com totais variando de $2,9 \mathrm{~mm}$ a $33,5 \mathrm{~mm}$, e do segundo decêndio de junho a agosto, com totais de 1,8mm a 11,2mm. Para esses períodos, os máximos totais aconteceram no segundo decêndio de outubro, com 24,5mm, no segundo de novembro, com 33,5mm, e no primeiro de dezembro, 34,3mm. A produtividade desse ano foi de 2,6 ton/ha acima da média (Figura 56, $D_{1}$ );

No ano agrícola de 1986/87 só não houve DEF no primeiro e segundo decêndios de fevereiro, nos decêndios de março, no primeiro e segundo de maio e do segundo até o terceiro de julho. Os totais de DEF dos demais decêndios variaram de $1,1 \mathrm{~mm}$ a $38,7 \mathrm{~mm}$. Os máximos totais ocorreram nos segundos decêndios de outubro e novembro, com 27,7 mm e $38 \mathrm{~mm}$, seguidos do primeiro de dezembro, com $37,9 \mathrm{~mm}$. A produtividade nessas condições ficou 2,6 ton/ha abaixo da média (Figura 56, $D_{2}$ ).

Diante do exposto até 0 momento, as variáveis hídricas e seus relacionamentos com a produtividade tiveram nível de correlação significativa para a variável DEF (determinada pelo BH Sequencial) e produtividade em Cambé.

Como os dois tipos de $\mathrm{BH}$ utilizados levam em conta as condições de disponibilidade de água em solo coberto por uma vegetação padrão e têm por objetivo a caracterização de disponibilidade hídrica e de seca e de aptidão de 
culturas, optou-se por um terceiro tipo de $\mathrm{BH}$. Este é denominado $\mathrm{BH}$ de Cultura e visa calcular o balanço de água no solo levando em consideração tanto o tipo de vegetação como seus estádios fenológicos.

\subsection{4 - Balanço Hídrico de Cultura e a produtividade da cana-de-açúcar}

$\mathrm{O} \mathrm{BH}$ de Cultura, como descrito na metodologia, utilizou dados de um período de 30 anos (1976 a 2006). Desses dados, empregaram-se os das variáveis de EXC e DEF para os últimos 25 anos agrícolas, 1981/82 a 2005/06, período que coincide com a disponibilidade dos dados de produção da cultura da cana-de-açúcar.

Além das demais análises empregadas, as variáveis hídricas foram

submetidas, sobretudo, a análises anuais por fase fenológica (estabelecimento/perfilhamento, desenvolvimento vegetativo e maturação), conforme segue.

\subsubsection{1 - Análise anual das variáveis hídricas e produtividade}

Para o município de Cambé, as médias do período de 30 anos para essas variáveis foram de 1.041,9 mm/ano para o EXC e de 41,2 mm/ano para a DEF, enquanto que para o período de 25 anos as médias foram de 1.065,1 mm/ano e de $38,9 \mathrm{~mm} / \mathrm{ano}$, respectivamente (Tabela 23 ).

O município de Mirador apresentou médias do período de 30 anos para as variáveis EXC e DEF de 1.016,0 mm/ano e de 69,6 mm/ano, respectivamente, enquanto que para o período de 25 anos as médias foram de 1027,4 mm/ano para o EXC e de 67,9 mm/ano para a DEF (Tabela 23). 
Tabela 23 - Dados anuais de EXC $(\mathrm{mm})$ e DEF $(\mathrm{mm})$ do BH de Cultura, dados de produtividade (ton/ha), seus desvios e coeficientes de correlações para os anos agrícolas de 1981/82 a 2005/06 em Cambé e Mirador, PR.

\begin{tabular}{|c|c|c|c|c|c|c|c|c|c|c|c|c|}
\hline \multirow[b]{2}{*}{$\begin{array}{l}\text { Ano } \\
\text { agrícola }\end{array}$} & \multicolumn{6}{|c|}{ Cambé } & \multicolumn{6}{|c|}{ Mirador } \\
\hline & EXC & $d_{i} E X C$ & DEF & \begin{tabular}{|l}
$d_{i}$ \\
DEF
\end{tabular} & Produt & \begin{tabular}{|l|}
$\mathbf{d}_{\mathrm{i}}$ \\
Produt \\
\end{tabular} & EXC & $d_{i} E X C$ & DEF & \begin{tabular}{|l}
$\mathbf{d}_{\mathrm{i}}$ \\
$\mathrm{DEF}$
\end{tabular} & Produt & \begin{tabular}{|l|}
$d_{i}$ \\
Produt \\
\end{tabular} \\
\hline $1981 / 82$ & 1221,6 & 56,6 & 44,5 & 5,6 & 115,6 & 33,2 & 971,0 & $-56,4$ & 44,9 & $-23,0$ & 78,1 & 1,9 \\
\hline $1982 / 83$ & 1852,5 & 787,4 & 29,2 & $-9,7$ & 90,8 & 8,4 & 1759,6 & 732,2 & 47,7 & $-20,1$ & 79,5 & 3,3 \\
\hline $1983 / 84$ & 1018,7 & $-46,3$ & 62,7 & 23,8 & 57,6 & $-24,8$ & 821,1 & $-206,3$ & 127,6 & 59,7 & 62,4 & $-13,8$ \\
\hline $1984 / 85$ & 944,5 & $-120,6$ & 43,6 & 4,7 & 68,9 & $-13,5$ & 895,3 & $-132,1$ & 57,2 & $-10,7$ & 79,1 & 2,9 \\
\hline $1985 / 86$ & 400,7 & $-664,4$ & 16,2 & $-22,7$ & 80,7 & $-1,8$ & 648,2 & $-379,3$ & 71,8 & 3,9 & 78,8 & 2,6 \\
\hline $1986 / 87$ & 1211,0 & 145,9 & 8,8 & $-30,1$ & 79,2 & $-3,2$ & 1146,3 & 18,9 & 78,2 & 10,4 & 73,6 & $-2,6$ \\
\hline $1987 / 88$ & 1220,8 & 155,7 & 46,4 & 7,5 & 78,6 & $-3,8$ & 841,0 & $-186,4$ & 116,7 & 48,8 & 70,2 & $-6,0$ \\
\hline $1988 / 89$ & 884,0 & $-181,0$ & 29,3 & $-9,6$ & 66,4 & $-16,0$ & 1054,7 & 27,3 & 36,3 & $-31,6$ & 89,0 & 12,8 \\
\hline $1989 / 90$ & 1398,5 & 333,4 & 53,8 & 14,9 & 68,9 & $-13,5$ & 1282,2 & 254,8 & 59,0 & $-8,8$ & 68,0 & $-8,2$ \\
\hline $1990 / 91$ & 748,8 & $-316,3$ & 37,6 & $-1,3$ & 81,3 & $-1,1$ & 731,3 & $-296,1$ & 94,1 & 26,2 & 67,4 & $-8,8$ \\
\hline $1991 / 92$ & 1415,3 & 350,2 & 17,3 & $-21,6$ & 97,6 & 15,2 & 1303,5 & 276,1 & 38,5 & $-29,4$ & 77,3 & 1,1 \\
\hline $1992 / 93$ & 1179,8 & 114,7 & 23,9 & $-15,0$ & 83,0 & 0,6 & 1040,1 & 12,7 & 42,8 & $-25,1$ & 76,8 & 0,6 \\
\hline $1993 / 94$ & 1066,3 & 1,2 & 22,6 & $-16,3$ & 74,9 & $-7,5$ & 852,5 & $-174,9$ & 50,2 & $-17,7$ & 80,5 & 4,3 \\
\hline $1994 / 95$ & 965,2 & $-99,9$ & 18,9 & $-20,0$ & 90,2 & 7,8 & 614,0 & $-413,4$ & 52,8 & $-15,0$ & 96,2 & 20,0 \\
\hline $1995 / 96$ & 1001,6 & $-63,5$ & 65,2 & 26,3 & 102,7 & 20,3 & 1092,9 & 65,5 & 50,9 & $-16,9$ & 84,7 & 8,5 \\
\hline $1996 / 97$ & 1782,8 & 717,8 & 97,5 & 58,6 & 78,0 & $-4,4$ & 1649,9 & 622,4 & 92,4 & 24,6 & 77,7 & 1,5 \\
\hline $1997 / 98$ & 1178,4 & 113,3 & 6,3 & $-32,6$ & 87,6 & 5,2 & 1494,5 & 467,1 & 17,6 & $-50,3$ & 86,3 & 10,1 \\
\hline $1998 / 99$ & 1240,3 & 175,3 & 43,6 & 4,7 & 89,2 & 6,8 & 1041,8 & 14,4 & 81,5 & 13,6 & 77,1 & 0,9 \\
\hline $1999 / 00$ & 703,7 & $-361,3$ & 34,2 & $-4,8$ & 78,8 & $-3,6$ & 919,0 & $-108,4$ & 56,2 & $-11,7$ & 54,3 & $-21,9$ \\
\hline $2000 / 01$ & 1119,0 & 54,0 & 4,8 & $-34,1$ & 91,1 & 8,7 & 924,8 & $-102,7$ & 33,7 & $-34,2$ & 68,4 & $-7,8$ \\
\hline $2001 / 02$ & 930,6 & $-134,5$ & 40,9 & 2,0 & 75,2 & $-7,2$ & 897,6 & $-129,8$ & 124,0 & 56,1 & 76,2 & 0,0 \\
\hline $2002 / 03$ & 695,2 & $-369,9$ & 39,4 & 0,5 & 102,8 & 20,4 & 915,4 & $-112,1$ & 27,9 & $-39,9$ & 65,2 & $-11,0$ \\
\hline $2003 / 04$ & 839,0 & $-226,1$ & 29,3 & $-9,7$ & 88,8 & 6,4 & 995,4 & $-32,1$ & 87,5 & 19,7 & 80,2 & 4,0 \\
\hline $2004 / 05$ & 786,2 & $-278,8$ & 96,9 & 58,0 & 58,0 & $-24,4$ & 751,1 & $-276,4$ & 118,8 & 50,9 & 78,0 & 1,8 \\
\hline $2005 / 06$ & 822,1 & $-243,0$ & 60,0 & 21,1 & 74,3 & $-8,1$ & 1042,5 & 15,1 & 88,5 & 20,7 & 81,2 & 5,0 \\
\hline Média & 1065,1 & & 38,9 & & 82,4 & & \begin{tabular}{|l|}
1027,4 \\
\end{tabular} & & 67,9 & & 76,2 & \\
\hline$r$ & & 0,2 & & $-0,3$ & & & & 0,1 & & $-0,2$ & & \\
\hline$t(n-1)$ & & 1,0 & & 1,5 & & & & 0,6 & & 1,2 & & \\
\hline
\end{tabular}

Org.: Domingues, I.A.S. (2009).

4.7.4.2 - Análise de desvio em relação à média para as variáveis EXC, DEF e Produtividade nos municípios de Cambé e Mirador

Em Cambé: para a variável EXC houve 12 anos com desvios positivos (Figura $\left.57, A_{1}\right)$. Desses, 7 anos com desvios de produtividade também positivos $(58,3 \%)$ e 5 com desvios negativos de produtividade, embora 2 desses anos apresentassem desvio de DEF também positivo, ou seja, além de o EXC estar acima da média, a 
DEF também esteve. O número de anos com desvios negativos de EXC foi de 13, dos quais 9 apresentaram produtividade negativa. Esse valor indica que $69,2 \%$ dos anos com queda na produtividade coincidiram com os anos com EXC abaixo da média.

Quanto à variável DEF, ocorreram 11 anos com desvios positivos (ano mais seco) e, desses, 8 apresentaram produtividades com desvios negativos (Figura 57, $A_{2}$ ). Ou seja, 66,6\% dos anos com DEF acima da média tiveram queda de produtividade. Para os 13 demais anos, os desvios de DEF foram negativos e, desses, 7 anos tiveram desvios de produtividade positiva. A variação para anos mais secos ou menos secos pode explicar em $60 \%$ as reduções ou os aumentos de produtividade. Santos (1992) identificou para essa cultura redução de produtividade de10\% a 40\% em decorrência da deficiência hídrica.

Em Mirador: a situação de EXC no período estudado foi de 11 anos com desvios positivos e, desses, 9 com desvios de produtividade também positivos (Figura $57, \mathrm{~B}_{1}$ ). Essa condição mostra que $81 \%$ dos anos com EXC acima da média tiveram produtividade também acima da média. $O$ número de anos com desvios negativos de EXC foi de 14 e, desses, 6 apresentaram produtividade com desvio negativo, ou seja, $42,9 \%$ de queda de produtividade podem ser explicados pelo EXC abaixo da média. As condições de EXC acima ou abaixo da média podem influenciar em $68 \%$ os valores de aumento ou queda na produtividade.

Para a variável DEF houve 11 anos com desvios positivos (mais seco que a média) e 14 com desvios negativos (menos seco que a média) (Figura 57, $\mathrm{B}_{2}$ ). Dos positivos, 4 tiveram desvios negativos de produtividade. Dos negativos, 10 anos apresentaram desvios positivos de produtividades. Esses números indicam que pode haver $56 \%$ de probabilidade de aumentar ou diminuir a produtividade pelo aumento ou redução dessa variável hídrica. 

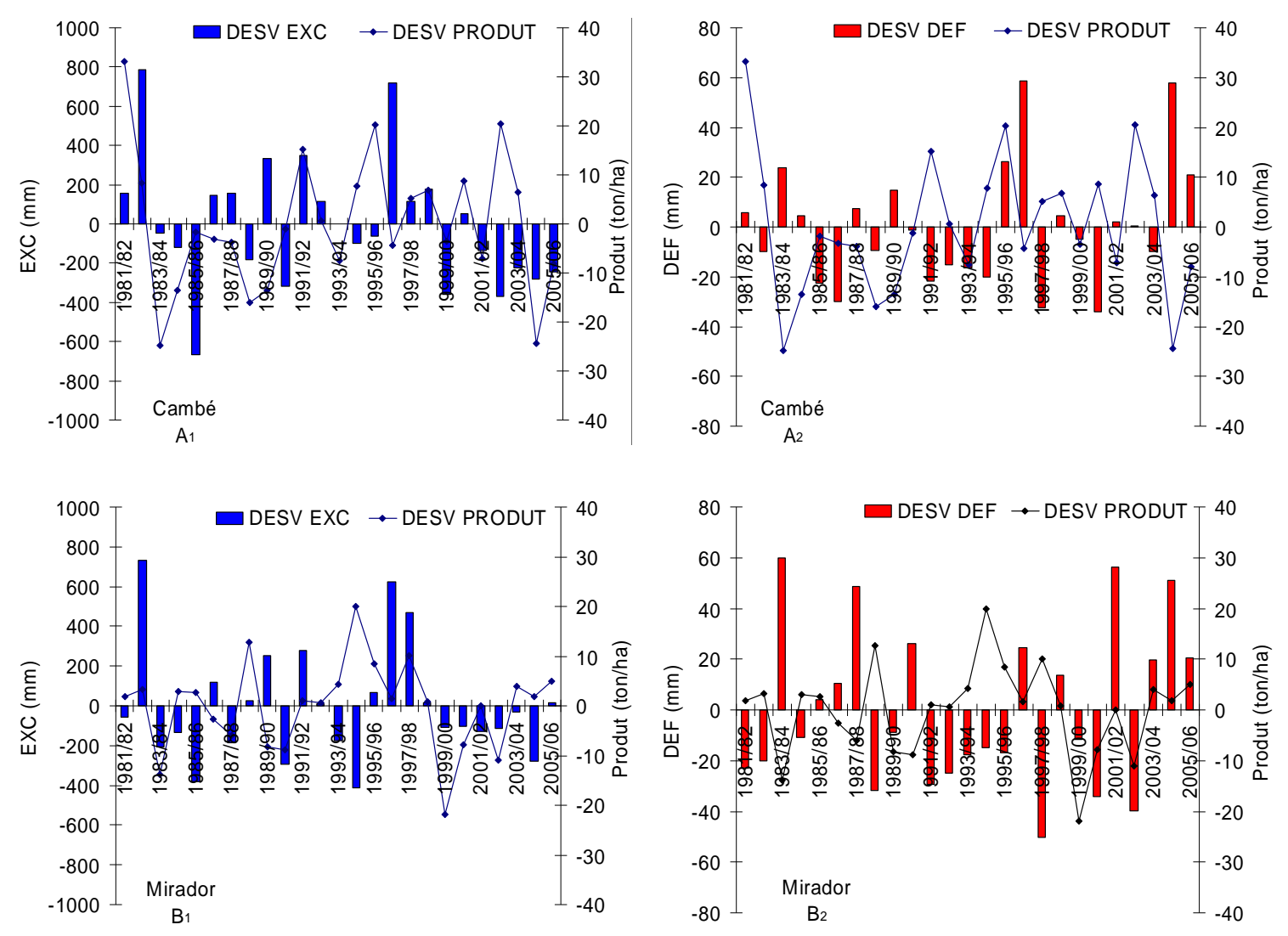

Figura 57 - Desvios de EXC, DEF e produtividade da cana-de-açúcar nos municípios de Cambé e Mirador, anos agrícolas 1981/82 a 2004/05.

Org.: Domingues, I.A.S. (2009).

\subsubsection{3 - Análise de correlação entre as variáveis hídricas e produtividade}

No município de Cambé a correlação entre EXC hídrico e produtividade foi considerada fraca, com coeficiente positivo de $r=0,2$, e para a DEF e produtividade correlação moderada, apresentando coeficiente negativo de $r=-0,3$ (Figura 58, A e A1). Pelo teste $t$ de Student, a nível de significância de $10 \%$, existe correlação significativa apenas entre DEF e produtividade.

Para Mirador a correlação foi fraca entre EXC e produtividade, com coeficiente de correlação positivo de $r=0,1$. A correlação foi fraca também para DEF e produtividade, com coeficiente de correlação negativo, $r=-0,2$ (Figura 58, B e B1). 
O teste $t$ de Student confirmou, a nível de 10\%, que não existe correlação significativa entre as variáveis EXC/DEF e produtividade nesse município.

Essas correlações em gráficos de dispersões ilustram nuvens de pontos com distribuição dispersa, revelando fraca correlação entre as variáveis EXC em Cambé e em Mirador e DEF em Mirador (Figura 58 A, B e B1), com exceção da DEF em Cambe, que apresentou correlação moderada (Figura 58 A1).
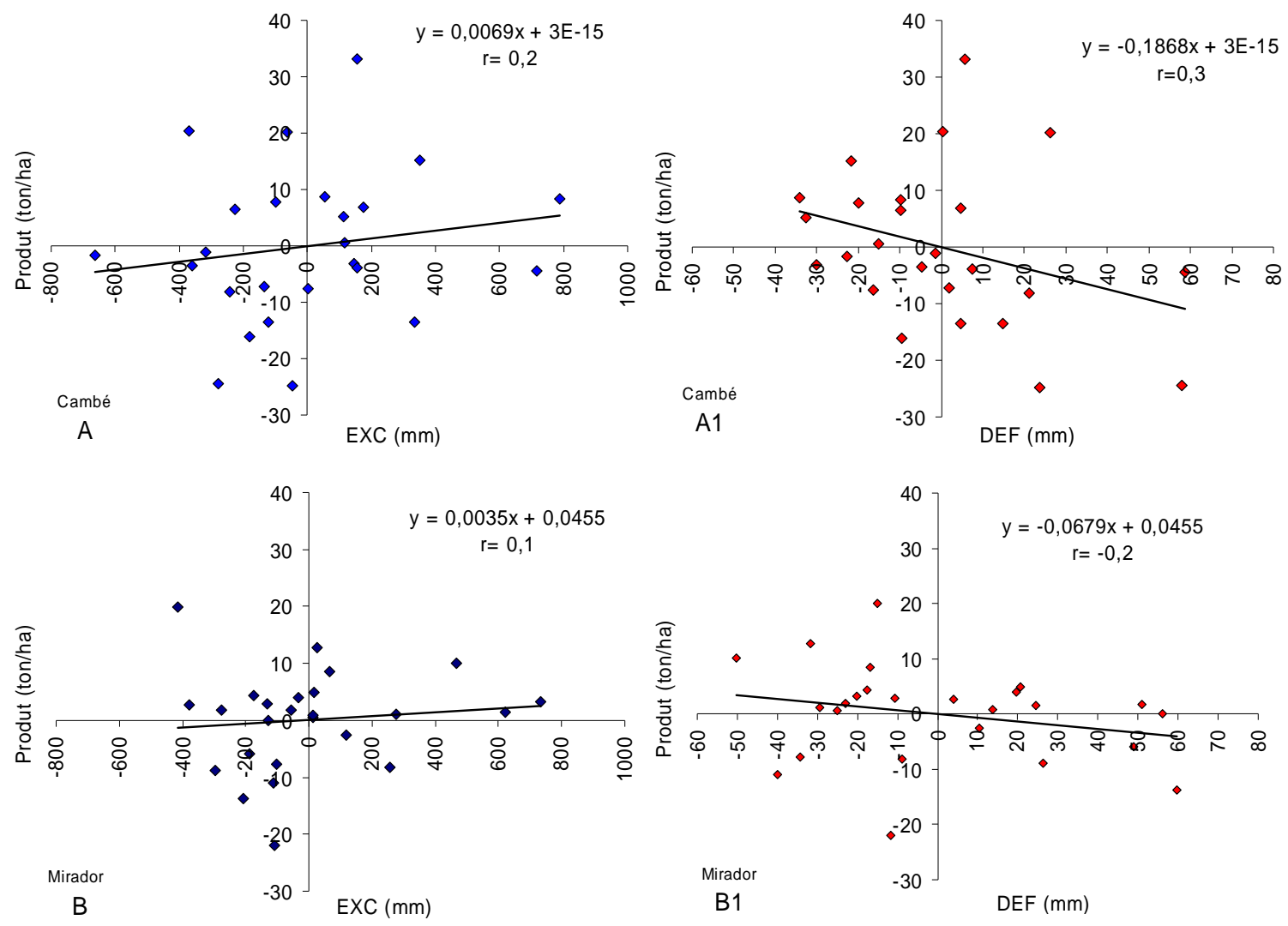

Figura 58 - Dispersão entre EXC/DEF e produtividade da cana-de-açúcar nos municípios de Cambé e Mirador, anos agrícolas 1981/82 a 2005/06.

Org.: Domingues, I.A.S. (2009).

\subsubsection{4 - Análise das variáveis hídricas por estádio fenológico e produtividade}

As variáveis hídricas e a variável produtividade foram analisadas também por estádios fenológicos (brotação/estabelecimento/perfilhamento, desenvolvimento e maturação) do ciclo de produção. Os dados de cada estádio foram submetidos a 
cálculo da média do período, dos totais anuais, dos desvios em relação à média, da correlação, do teste $t$ de Student (Tabela 24) e da análise do extrato do $\mathrm{BH}$ de Cultura.

Quanto às médias do período, foram os seguintes os totais anuais por fase fenológica e desvios em relação à média:

Em Cambé a média do período para a variável EXC no estádio de estabelecimento foi de $323,0 \mathrm{~mm}$; no desenvolvimento $478,2 \mathrm{~mm}$; e na maturação com 263,9mm. A média de DEF nesses estádios foi de 1,2mm,14,7mm e 23,0mm, respectivamente. Em média e em condições de campo, a cana-de-açúcar consome $3,25 \mathrm{~mm} \mathrm{dia}^{-1}$ (SCARDUA, 1987).

Os maiores totais anuais de EXC ocorreram da seguinte forma: para o estádio de estabelecimento, 630,7mm em 1983/84 e de 536,6mm em 1996/97; estádio de desenvolvimento, total de $829,4 \mathrm{~mm}$ em 1982/83 e de $831,8 \mathrm{~mm}$ em 1996/97; estádio de maturação, 719,0mm em 1982/83 e de 526,1 mm em 1986/87 (Tabela 24).

Quanto à DEF, os maiores totais anuais por estádios foram: estabelecimento com 3,5mm nos anos de 1988/89, 1996/97 e 2002/03; desenvolvimento com 49,8mm em 1989/90 e 52,5mm em 1996/97; e maturação com 45,4 em 1983/84 e 51,7mm em 1995/96 (Tabela 24).

Em Mirador a média do período por estádios para o EXC foi de: estabelecimento $348,0 \mathrm{~mm}$; desenvolvimento $395,5 \mathrm{~mm}$; e maturação $283,5 \mathrm{~mm}$. Para a DEF: estabelecimento 2,8mm; desenvolvimento $29,8 \mathrm{~mm}$; e maturação $35,2 \mathrm{~mm}$ (Tabela 24).

Os maiores totais anuais do EXC por estádios foram de: estabelecimento 242,2mm em 1983/84 e de 274,8 em 1997/98; desenvolvimento 611,0mm em 1982/83 e de 939,5mm em 1996/97; maturação 703,3mm em 1982/83 e 704,8mm em 1991/92. Para a DEF, os valores foram de estabelecimento 9,3mm em 1985/86 e 8,0mm em 1988/89; desenvolvimento 7,2mm em 1996/97 e 85,3mm em 2004/05; maturação 38,7mm em 1983/84 e 88,7mm em 1987/88 (Tabela 24). 
Tabela 24 - Dados anuais por fases fenológicas das variáveis de EXC $(\mathrm{mm})$, DEF $(\mathrm{mm})$ e produtividade (ton/ha), seus desvios e correlações, municípios de Cambé e Mirador, anos agrícolas de 1981/82 a 2005/06.

\begin{tabular}{|c|c|c|c|c|c|c|c|c|c|c|c|c|c|c|}
\hline \multirow[b]{2}{*}{ Cambé } & \multicolumn{2}{|c|}{ Estab } & \multicolumn{2}{|c|}{$\mathrm{d}_{\mathrm{i}}$} & \multicolumn{2}{|c|}{ Desenv } & \multicolumn{2}{|c|}{$d_{i}$} & \multicolumn{2}{|c|}{ Maturaç } & \multicolumn{2}{|c|}{$\mathrm{d}_{\mathrm{i}}$} & \multirow[t]{2}{*}{ Produt } & \multirow[t]{2}{*}{$d_{i}$} \\
\hline & Exc & Def & Exc & Def & Exc & Def & Exc & Def & Exc & Def & Exc & Def & & \\
\hline $1981 / 82$ & 352,0 & 1,2 & 29,0 & 0,0 & 528,4 & 9,3 & 50,2 & $-5,4$ & 341,3 & 34,0 & 77,4 & 10,9 & 115,6 & 33,2 \\
\hline $1982 / 83$ & 304,0 & 0,0 & $-19,0$ & $-1,2$ & 209,3 & 12,4 & 351,2 & $-2,3$ & 719,0 & 16,9 & 455,1 & $-6,2$ & 90,8 & 8,4 \\
\hline $1983 / 84$ & 630,7 & 0,0 & 307,8 & $-1,2$ & 216,7 & 17,3 & $-268,8$ & 2,6 & 178,6 & 45,4 & $-85,3$ & 22,3 & 57,6 & $-24,8$ \\
\hline $1984 / 85$ & 196,5 & 3,3 & $-126,5$ & 2,1 & 393,1 & 18,6 & $-25,4$ & 4,0 & 295,2 & 21,7 & 31,3 & $-1,4$ & 68,9 & $-13,5$ \\
\hline $1985 / 86$ & 81,6 & 0,6 & $-241,4$ & $-0,7$ & 595,7 & 5,6 & $-261,5$ & $-9,0$ & 102,4 & 10,0 & $-165,5$ & $-13,0$ & 80,7 & $-1,8$ \\
\hline $1986 / 87$ & 185,7 & 0,6 & $-137,3$ & $-0,7$ & 668,2 & 4,4 & 21,0 & $-10,2$ & 526,1 & 3,8 & 262,2 & $-19,3$ & 79,2 & $-3,2$ \\
\hline $1987 / 88$ & 505,0 & 0,0 & 182,0 & $-1,2$ & 556,4 & 11,4 & $-85,1$ & $-3,3$ & 322,7 & 35,0 & 58,8 & 12,0 & 78,6 & $-3,8$ \\
\hline $1988 / 89$ & 190,2 & 3,5 & $-132,8$ & 2,2 & 605,3 & 13,0 & $-53,6$ & $-1,7$ & 269,2 & 12,8 & 5,3 & $-10,2$ & 66,4 & $-16,0$ \\
\hline $1989 / 90$ & 316,3 & 0,0 & $-6,7$ & $-1,2$ & 363,2 & 49,8 & 117,5 & 35,1 & 486,5 & 4,1 & 222,6 & $-19,0$ & 68,9 & $-13,5$ \\
\hline 1990/91 & 344,3 & 1,2 & 21,3 & 0,0 & 365,8 & 16,2 & $-187,3$ & 1,5 & 113,7 & 20,3 & $-150,2$ & $-2,8$ & 81,3 & $-1,1$ \\
\hline $1991 / 92$ & 330,8 & 3,4 & 7,8 & 2,1 & 489,2 & 8,2 & 190,0 & $-6,4$ & 416,4 & 5,7 & 152,5 & $-17,4$ & 97,6 & 15,2 \\
\hline 1992/93 & 527,7 & 0,0 & 204,7 & $-1,2$ & 313,6 & 12,7 & 30,4 & $-1,9$ & 143,5 & 11,2 & $-120,4$ & $-11,9$ & 83,0 & 0,6 \\
\hline 1993/94 & 264,6 & 0,8 & $-58,4$ & $-0,4$ & 368,9 & 9,2 & 78,2 & $-5,5$ & 245,3 & 12,6 & $-18,6$ & $-10,5$ & 74,9 & $-7,5$ \\
\hline $1994 / 95$ & 202,5 & 0,7 & $-120,5$ & $-0,5$ & 614,3 & 13,4 & 136,2 & $-1,2$ & 148,3 & 4,8 & $-115,6$ & $-18,2$ & 90,2 & 7,8 \\
\hline /96 & 396,3 & 1,5 & 73,3 & 0,3 & 605,3 & 6,6 & 127,1 & $-8,0$ & 0,0 & 57,1 & $-263,9$ & 34,1 & 102,7 & 20,3 \\
\hline $1996 / 97$ & 536,6 & 3,5 & 213,6 & 2,2 & 831,8 & 52,5 & 353,6 & 37,9 & 414,5 & 41,5 & 150,6 & 18,5 & 78,0 & $-4,4$ \\
\hline $1997 / 98$ & 368,9 & 0,0 & 45,9 & $-1,2$ & 363,2 & 4,6 & $-115,0$ & $-10,1$ & 446,4 & 1,7 & 182,4 & $-21,3$ & 87,6 & 5,2 \\
\hline $1998 / 99$ & 473,9 & 0,9 & 151,0 & $-0,4$ & 498,5 & 6,9 & 20,3 & $-7,8$ & 267,9 & 35,9 & 4,0 & 12,8 & 89,2 & 6,8 \\
\hline $1999 / 00$ & 172,9 & 2,5 & $-150,1$ & 1,3 & 365,8 & 7,4 & $-112,4$ & $-7,2$ & 165,1 & 24,2 & $-98,8$ & 1,2 & 78,8 & $-3,6$ \\
\hline $2000 / 01$ & 311,6 & 0,0 & $-11,4$ & $-1,2$ & 499,3 & 0,0 & 21,1 & $-14,6$ & 308,1 & 4,8 & 44,2 & $-18,3$ & 91,1 & 8,7 \\
\hline $2001 / 02$ & 222,1 & 1,4 & $-100,9$ & 0,2 & 489,2 & 5,2 & 11,0 & $-9,5$ & 219,3 & 34,4 & $-44,6$ & 11,3 & 75,2 & $-7,2$ \\
\hline $002 / 03$ & 213,5 & 3,5 & $-109,5$ & 2,3 & 412,8 & 17,6 & $-65,4$ & 2,9 & 68,9 & 18,3 & $-195,0$ & $-4,7$ & 102,8 & 20,4 \\
\hline 104 & 177,8 & 0,0 & $-145,2$ & $-1,2$ & 313,6 & 4,7 & $-164,5$ & $-9,9$ & 347,6 & 24,5 & 83,7 & 1,4 & 88,8 & 6,4 \\
\hline $2004 / 05$ & 339,8 & 2,0 & 16,8 & 0,8 & 418,5 & 45,4 & $-59,7$ & 30,8 & 28,0 & 49,5 & $-235,9$ & 26,4 & 58,0 & $-24,4$ \\
\hline $2005 / 06$ & 429,7 & 0,0 & 106,7 & $-1,2$ & 368,9 & 13,9 & $-109,2$ & $-0,7$ & 23,4 & 46,1 & $-240,5$ & 23,0 & 74,3 & $-8,1$ \\
\hline Média & 323,0 & 1,2 & & & 478,2 & 14,7 & & & 263,9 & 23,0 & & & 82,4 & \\
\hline$r$ & & & $-0,10$ & 0,03 & & & 0,31 & $-0,43$ & & & 0,11 & $-0,12$ & & \\
\hline$t(n-1)$ & & & 0,50 & 0,10 & & & 1,50 & 2,00 & & & 0,50 & 0,50 & & \\
\hline \multicolumn{15}{|l|}{ Mirador } \\
\hline $1981 / 82$ & 462,2 & 3,9 & 114,2 & 1,1 & 30,3 & 27,1 & $-215,2$ & $-2,7$ & 328,5 & 13,9 & 45,0 & $-21,4$ & 78,1 & 1,9 \\
\hline 83 & 445,3 & 0,5 & 97,4 & $-2,3$ & 611,0 & 9,8 & 215,4 & $-20,0$ & 703,3 & 37,4 & 419,8 & 2,2 & 79,5 & 3,3 \\
\hline $1983 / 84$ & 550,6 & 0,0 & 202,6 & $-2,8$ & 180,6 & 53,7 & $-214,9$ & 23,8 & 89,9 & 73,9 & $-193,7$ & 38,7 & 62,4 & $-13,8$ \\
\hline $1984 / 85$ & 290,7 & 3,8 & $-57,2$ & 0,9 & 497,4 & 13,7 & 101,9 & $-16,1$ & 107,2 & 39,7 & $-176,4$ & 4,5 & 79,1 & 2,9 \\
\hline $1985 / 86$ & 105,7 & 9,3 & $-242,2$ & 6,5 & 311,9 & 19,6 & $-83,7$ & $-10,2$ & 230,6 & 42,8 & $-52,9$ & 7,6 & 78,8 & 2,6 \\
\hline $1986 / 87$ & 122,0 & 5,9 & $-225,9$ & 3,1 & 402,1 & 63,6 & 6,5 & 33,8 & 622,3 & 8,7 & 338,8 & $-26,5$ & 73,6 & $-2,6$ \\
\hline $1987 / 88$ & 460,4 & 0,0 & 112,4 & $-2,8$ & 319,7 & 28,0 & $-75,8$ & $-1,9$ & 60,9 & 88,7 & $-222,6$ & 53,5 & 70,2 & $-6,0$ \\
\hline $1988 / 89$ & 250,1 & 8,0 & $-97,9$ & 5,2 & 370,1 & 16,1 & $-25,5$ & $-13,7$ & 434,6 & 12,1 & 151,1 & $-23,1$ & 89,0 & 12,8 \\
\hline
\end{tabular}

continua... 
continuação

\begin{tabular}{|c|c|c|c|c|c|c|c|c|c|c|c|c|c|c|}
\hline \multirow[t]{2}{*}{ Mirador } & \multicolumn{2}{|c|}{ Estab } & \multicolumn{2}{|c|}{$\mathrm{d}_{\mathrm{i}}$} & \multicolumn{2}{|c|}{ Desenv } & \multicolumn{2}{|c|}{$\mathrm{d}_{\mathrm{i}}$} & \multicolumn{2}{|c|}{ Maturaç } & \multicolumn{2}{|c|}{$\mathrm{d}_{\mathrm{i}}$} & \multirow[t]{2}{*}{ Produt } & \multirow[t]{2}{*}{$\mathrm{d}_{\mathrm{i}}$} \\
\hline & Exc & Def & Exc & Def & Exc & Def & Exc & Def & Exc & Def & Exc & Def & & \\
\hline $1989 / 90$ & 296,6 & 2,9 & $-51,3$ & 0,1 & 513,2 & 48,6 & 117,6 & 18,8 & 472,4 & 7,5 & 188,9 & $-27,8$ & 68,0 & $-8,2$ \\
\hline $1990 / 91$ & 443,7 & 5,1 & 95,8 & 2,3 & 200,7 & 24,1 & $-194,8$ & $-5,8$ & 86,9 & 64,9 & $-196,6$ & 29,7 & 67,4 & $-8,8$ \\
\hline $1991 / 92$ & 170,4 & 6,1 & $-177,6$ & 3,2 & 428,3 & 25,8 & 32,8 & $-4,0$ & 704,8 & 6,6 & 421,3 & $-28,6$ & 77,3 & 1,1 \\
\hline 1992/93 & 461,7 & 0,0 & 113,8 & $-2,8$ & 357,4 & 28,6 & $-38,2$ & $-1,2$ & 210,1 & 14,1 & $-73,4$ & $-21,1$ & 76,8 & 0,6 \\
\hline $1993 / 94$ & 346,7 & 3,4 & $-1,2$ & 0,6 & 329,9 & 7,8 & $-65,6$ & $-22,1$ & 175,9 & 39,0 & $-107,6$ & 3,8 & 80,5 & 4,3 \\
\hline $1994 / 95$ & 208,6 & 0,5 & $-139,3$ & $-2,3$ & 375,8 & 18,8 & $-19,8$ & $-11,1$ & 29,6 & 33,6 & $-253,9$ & $-1,7$ & 96,2 & 20,0 \\
\hline $1995 / 96$ & 409,8 & 3,8 & 61,9 & 1,0 & 465,5 & 12,5 & 70,0 & $-17,3$ & 217,6 & 34,7 & $-65,9$ & $-0,6$ & 84,7 & 8,5 \\
\hline $1996 / 97$ & 445,2 & 2,5 & 97,2 & $-0,3$ & 939,5 & 71,2 & 544,0 & 41,4 & 265,2 & 18,7 & $-18,3$ & $-16,6$ & 77,7 & 1,5 \\
\hline $1997 / 98$ & 622,7 & 0,0 & 274,8 & $-2,8$ & 390,4 & 12,1 & $\begin{array}{l}-5,2 \\
\end{array}$ & $-17,8$ & 481,4 & 5,5 & 197,9 & $-29,7$ & 86,3 & 10,1 \\
\hline $1998 / 99$ & 462,0 & 0,8 & 114,0 & $-2,1$ & 402,7 & 25,7 & 7,2 & $-4,1$ & 177,1 & 55,0 & $-106,4$ & 19,8 & 77,1 & 0,9 \\
\hline $1999 / 00$ & 111,2 & 6,6 & $-236,8$ & 3,8 & 493,5 & 27,4 & 98,0 & $-2,5$ & 314,3 & 22,2 & 30,8 & $-13,0$ & 54,3 & $-21,9$ \\
\hline $2000 / 01$ & 352,3 & 0,0 & 4,4 & $-2,8$ & 361,5 & 3,7 & $-34,0$ & $-26,1$ & 210,9 & 29,9 & $-72,6$ & $-5,3$ & 68,4 & $-7,8$ \\
\hline $2001 / 02$ & 229,0 & 0,7 & $-118,9$ & $-2,1$ & 420,3 & 64,9 & 24,7 & 35,1 & 248,4 & 58,3 & $-35,1$ & 23,1 & 76,2 & 0,0 \\
\hline $2002 / 03$ & 239,7 & 1,4 & $-108,2$ & $-1,5$ & 468,9 & 3,4 & 73,4 & $-26,5$ & 206,7 & 23,2 & $-76,8$ & $-12,0$ & 65,2 & $-11,0$ \\
\hline $2003 / 04$ & 225,4 & 1,6 & $-122,6$ & $-1,2$ & 250,3 & 27,6 & $-145,2$ & $-2,2$ & 519,7 & 58,3 & 236,2 & 23,1 & 80,2 & 4,0 \\
\hline $2004 / 05$ & 444,9 & 3,6 & 97,0 & 0,8 & 280,3 & 85,3 & $-115,2$ & 55,5 & 25,8 & 29,8 & $-257,7$ & $-5,4$ & 78,0 & 1,8 \\
\hline $2005 / 06$ & 541,7 & 0,0 & 193,7 & $-2,8$ & 337,1 & 26,5 & $-58,4$ & $-3,3$ & 163,7 & 62,0 & $-119,8$ & 26,8 & 81,2 & 5,0 \\
\hline Média & 348,0 & 2,8 & & & 395,5 & 29,8 & & & 283,5 & 35,2 & & & 76,2 & \\
\hline$r$ & & & 0,09 & $-0,04$ & & & 0,04 & $-0,17$ & & & 0,07 & $-0,16$ & & \\
\hline$t(n-1)$ & & & 0,44 & 0,17 & & & 0,17 & 0,83 & & & 0,33 & 0,81 & & \\
\hline
\end{tabular}

Org: Domingues, I.A.S. (2009). 


\subsubsection{5 - Análise dos desvios de EXC/DEF e produtividade}

Em Cambé os maiores desvios de EXC $(\mathrm{mm})$, por ordem dos estádios fenológicos, foram (Tabela 24):

No estabelecimento, em 1983/84, desvio de +307,8 (DEF correspondente de $-1,2)$; já no desenvolvimento e maturação desse mesmo ano os desvios foram de $-268,5(\mathrm{DEF}-2,6)$ e de -85,3mm (DEF +22,3); nessa condição de falta de EXC no segundo estádio e DEF no terceiro, a produtividade teve desvio de -24,8 ton/ha (Figura 59, A1).

No desenvolvimento, 1996/97 teve desvio de +356,6 (DEF de +37,9), estabelecimento e maturação de +213,6 (DEF +2,2) e +150,6 (DEF +18,5) respectivamente. O desvio de EXC de 57,0\% na maturação pode ter causado o desvio de produtividade de $-4,4$ ton/ha nesse ano (Figura 59, A2).

Na maturação, 1982/83 teve desvio de $+455,1$ (DEF -6,2) e estabelecimento e desenvolvimento de -19,0 (DEF -1,2) e +351,2 (DEF -6,2); a condição de EXC na fase de maturação não atingiu a produtividade, que teve desvio de $+8,4$ ton/ha (Figura 59, A3).

Para a variável DEF ( $\mathrm{mm})$, os anos com os maiores desvios aconteceram por ordem de fases fenológicas:

No estabelecimento e desenvolvimento, em 1996/97, os valores dos desvios foram os mesmos descritos no desenvolvimento do maior desvio de EXC (Figura 59, B1 e B2).

Na maturação, em 1995/96, o desvio foi de $+34,1$ (EXC correspondente de -263,9) e no estabelecimento e desenvolvimento de +3,0 (EXC +73,3) e -8,0 (EXC $+127,1)$. Nessas condições hídricas o desvio da produtividade foi de $+20,3$ ton/ha (Figura 59, B3). 

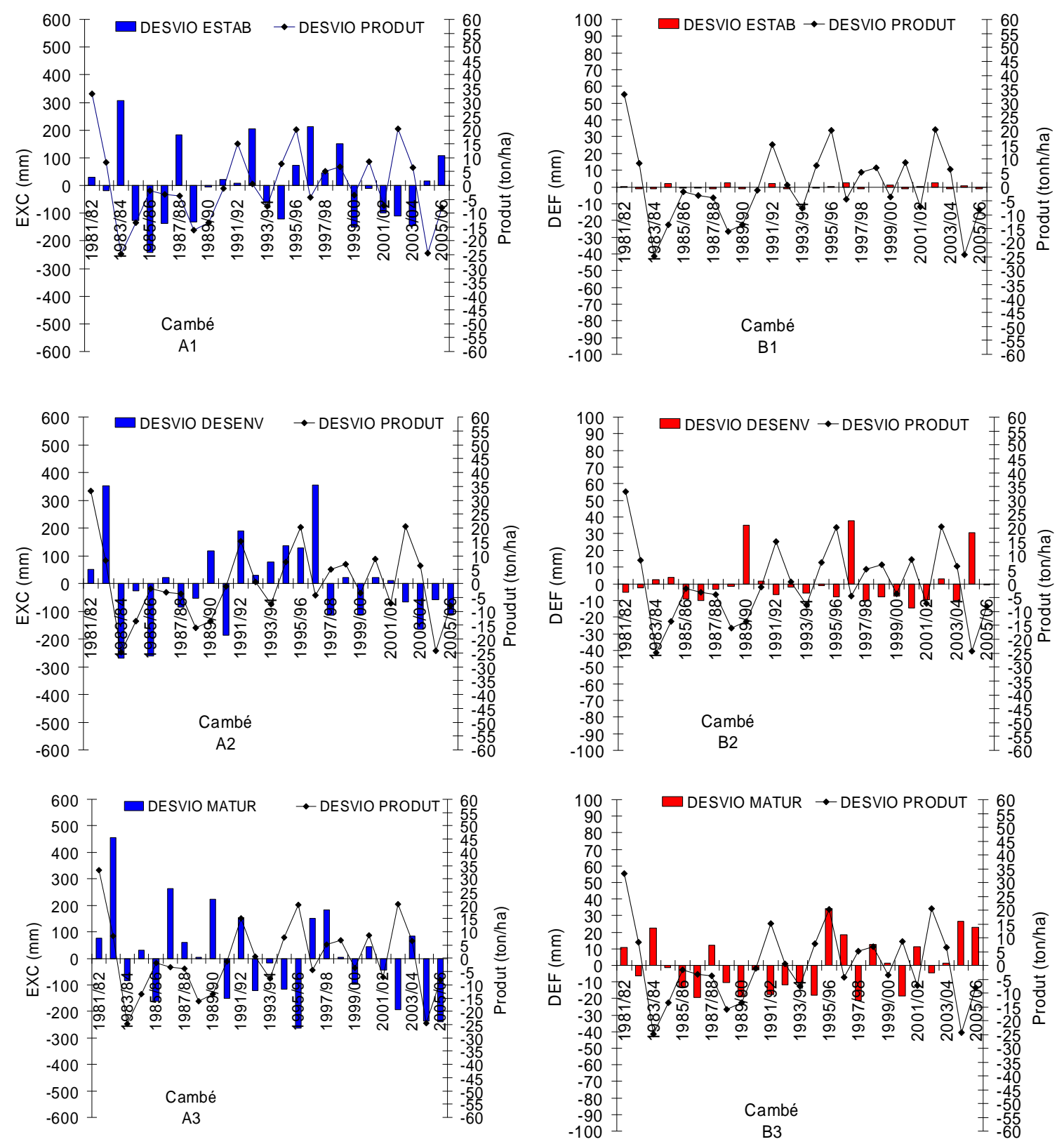

Figura 59 - Desvios de EXC/DEF por fase fenológica com a produtividade da cultura da cana-deaçúcar para o município de Cambé, período de 1981/82 a 2005/06.

Org.: Domingues, I.A.S. (2009).

Para o município de Mirador os anos com os maiores desvios de EXC (mm), por ordem de estádios fenológicos, foram (Tabela 24):

Estabelecimento do ano de 1985/86, com -242,2 (DEF correspondente $+0,3$ ) e desenvolvimento e maturação com -83,7 (DEF -10,2) e 52,9 (DEF 7,5), sendo o desvio de produtividade de $+2,6$ ton/ha (Figura 60 A1). 

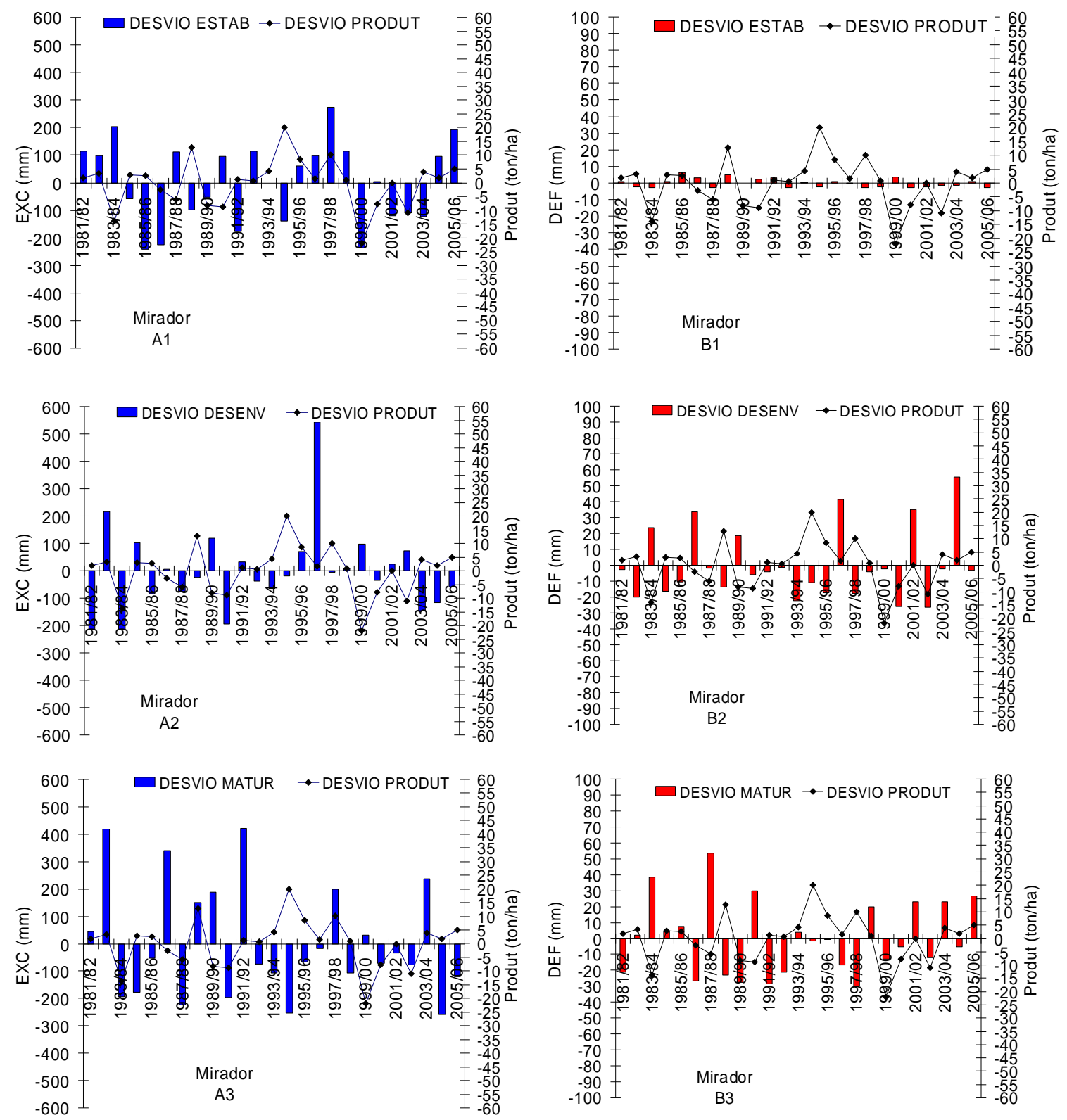

Figura 60 - Desvios de EXC/DEF por fase fenológica com a produtividade da cultura da cana-deaçúcar para o município de Mirador, período de 1981/82 a 2005/06.

Org.: Domingues, I.A.S. (2009). 
Desenvolvimento, em 1996/97, com +544,0 (DEF +41,4) No estabelecimento e maturação os EXC foram de 97,2 (DEF -0,3) e -18,3 (DEF -16,3). Nesse comportamento hídrico o desvio de produtividade foi de $+1,5$ ton/ha (Figura $60 \mathrm{~A} 2$ ).

Maturação, em 1991/92, com +421,3 (DEF -28,6). No estabelecimento e desenvolvimento os EXC foram de -177,6 (DEF +3,2) e de 32,8 (DEF -4,0). O desvio de produtividade nessas condições hídricas foi de $+1,1$ ton/ha (Figura 60 A3).

Para os anos com maiores desvios de DEF:

Estabelecimento, em 1985/86, coincidente com o estádio de estabelecimento do maior desvio do EXC, como já descrito (Figura 60 B1).

Desenvolvimento, em 2004/05, com $+55,5$ (EXC -115,2), e estabelecimento e maturação com +0,8 (EXC +97,0) e -5,4 (EXC -257,7). Nessa condição hídrica o desvio de produtividade foi de $+1,8$ ton/ha (Figura $60 \mathrm{~B} 2$ ).

Maturação, em 1987/88, com 53,5 (EXC -222,6), e estabelecimento e desenvolvimento DEF de -2,8 (EXC +112,4) e -1,9 (EXC -75,8). Nessa variação hídrica o desvio de produtividade foi de $-6,0$ ton/ha (Figura 60 B3).

\subsubsection{6 - Correlação entre as variáveis EXC/DEF e produtividade}

Com a finalidade de verificar se aumento (ou diminuição) das variáveis hídricas correspondem a aumento (ou diminuição) na variável produtividade, fez-se a análise de correlação como descrita a seguir:

Em Cambé, para as variáveis hídricas e produtividade, os maiores coeficientes de correlação ocorreram no estádio de desenvolvimento, com valores de $r=+0,3$ para o EXC e $r=-0,4$ para a DEF, portanto correlações consideradas moderadas. Confirmou-se pelo teste $t$ de Student a nível de significância de $10 \%$ que existe correlação significativa entre EXC e DEF no estádio desenvolvimento e produtividade (Tabela 24). O sinal positivo do coeficiente de correlação indica que a produtividade aumenta em razão do aumento de EXC, e o sinal negativo indica que quando há aumento da DEF a produtividade tende a diminuir (Figura 61, Desenvolv. 1 e 2). 
Nos demais estágios a correlação foi muito fraca, não havendo correlação significativa entre as variáveis, conforme ilustra o gráfico de dispersão, por apresentar a nuvem de pontos dispersa (Figura 61)
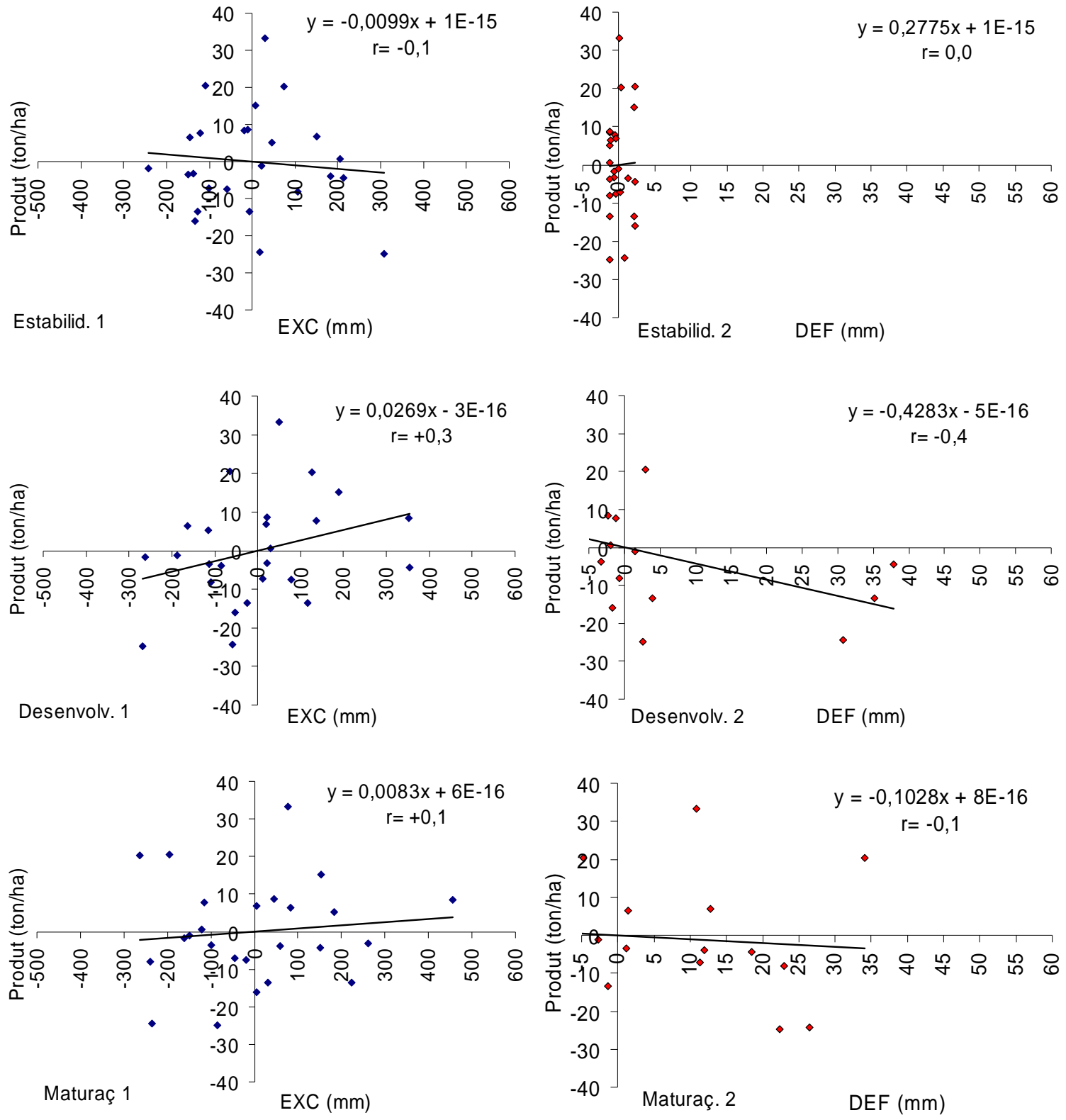

Figura 61 - Diagrama de dispersão das variáveis EXC/DEF com a produtividade da cana-de-açúcar em Cambé, anos agrícolas de 1981/82 a 2005/06.

Org.: Domingues, I.A.S. (2009). 
No município de Mirador a correlação foi muito fraca nos três estágios fenológicos, tanto para o EXC quanto para a DEF, embora o maior valor tenha ocorrido para a DEF no desenvolvimento e maturação, com coeficiente de $r=-0,2$. $O$ gráfico de correlação ilustra que a forma de distribuição dispersa dos pontos confere baixa correlação (Figura 62). A inexistência de correlação significativa foi confirmada pelo teste $t$ de Student a nível de significância de 10\% (Tabela 24).
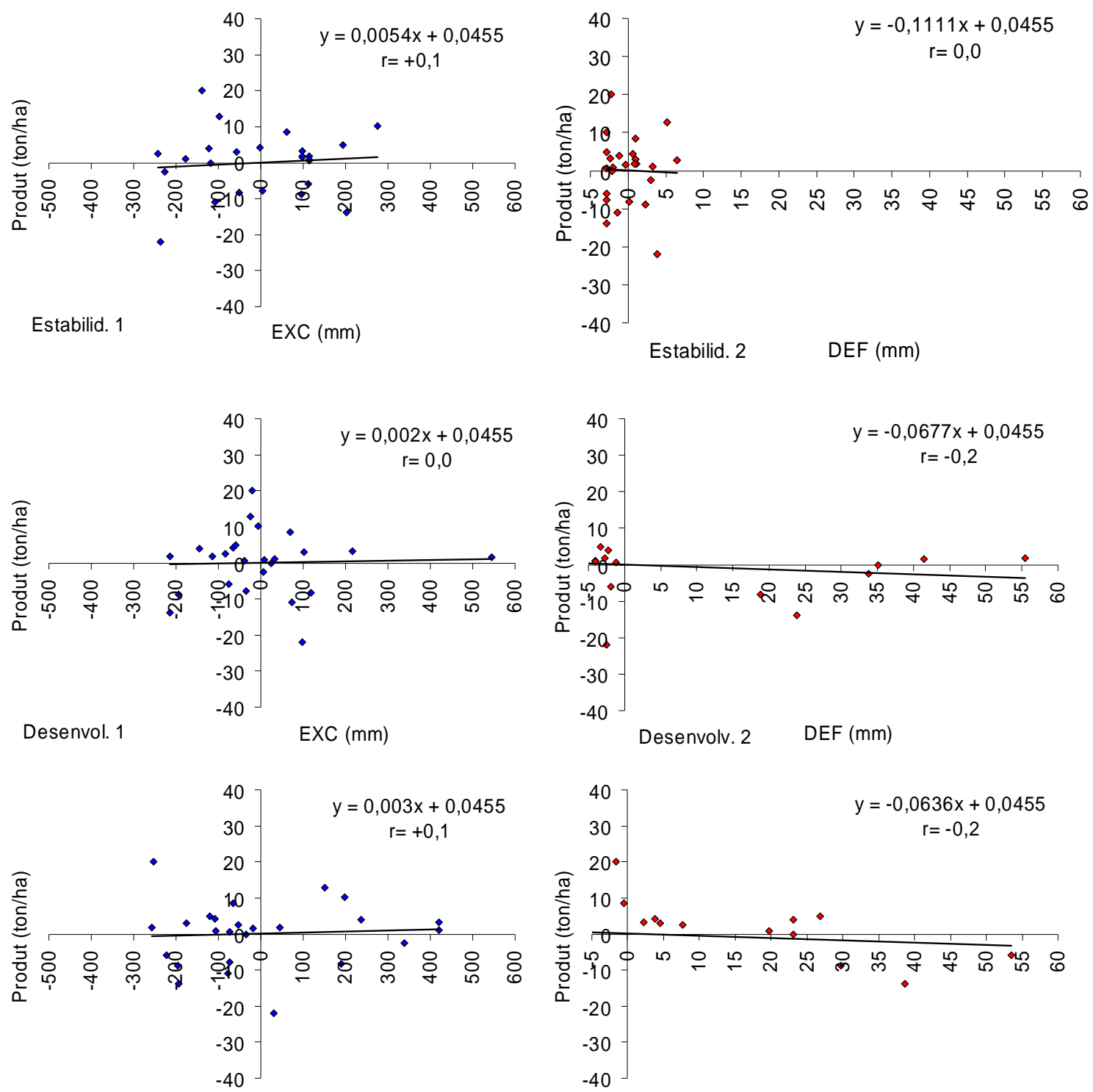

Maturaç. 1

EXC (mm)

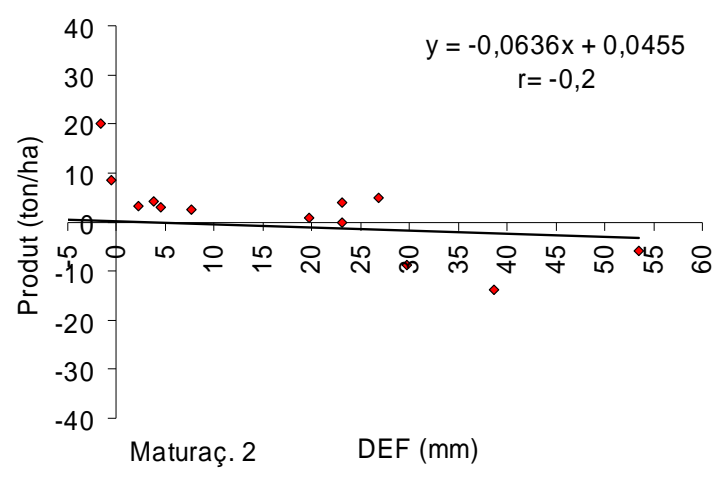

Figura 62 - Correlação e dispersão das variáveis EXC/DEF com a produtividade da cana-de-açúcar em Mirador, anos agrícolas 1981/82 a 2005/06.

Org.: Domingues, I.A.S. (2009). 
Dessa maneira, apenas no estádio de desenvolvimento, em Cambé, houve correlação significativa entre EXC e DEF com a produtividade, embora a análise visual dos dados anuais por estádios fenológicos (Tabela 14) sugere que, quando ocorrem condições desfavoráveis de EXC e DEF em pelo menos 83,0\% dos estágios, é comum haver redução de produtividade; mas o contrário também é verdadeiro. Percebeu-se também que, em Mirador (solo arenoso), 44,0\% dos anos com desvio positivo de EXC ou desvio negativo de DEF na maturação mantiveram a produtividade com desvios positivos, quando nos demais estádios a condição hídrica esteve favorável. Em Cambé (solo argiloso), apenas 32,0\% dos anos apresentaram essa condição.

\subsubsection{7 - Análise do extrato do BH de Cultura e produtividade}

$\mathrm{O}$ extrato do $\mathrm{BH}$ de Cultura foi elaborado para os anos com os maiores totais de EXC e DEF por estádio fenológico, na tentativa de um entendimento visual das variações hídricas no aumento ou diminuição da produtividade.

Em Cambé a variação do EXC e da DEF é mostrada por meio do extrato do $\mathrm{BH}$ de Cultura $(\mathrm{BHC})$, por ordem dos estádios do ciclo da cultura, conforme segue:

Para os anos agrícolas com os maiores totais de EXC:

No ano agrícola de 1983/84, com produtividade abaixo da média, o maior total de EXC ocorreu no Estabelecimento (desvio de 207,8mm acima da média). Embora no desenvolvimento o EXC estivesse abaixo da média do período (desvio de $268,8 \mathrm{~mm}$ ) e com DEF intercalada no segundo decêndio de janeiro, no terceiro de fevereiro e no segundo de março. Na maturação predominou DEF (desvio de 22,3mm da média) até o primeiro decêndio de agosto (Figura 63, ano 1983/84). A produtividade nesse ano teve redução de 30,1\% abaixo da média do período. Essa redução de produtividade pode ter sido em função da DEF no desenvolvimento e DEF muito prolongada na maturação.

O ano agrícola de 1996/97 apresentou o maior total de EXC no desenvolvimento vegetativo (desvio da média de 353,6mm). Embora com DEF do 
terceiro decêndio de fevereiro até o primeiro de maio (desvio da média de $37,9 \mathrm{~mm}$ ), seguido de elevados totais de EXC no primeiro e segundo decêndios de junho. Nessa variabilidade e distribuição hídrica a produtividade teve redução de 5,4\% da média (Figura 63, ano 1996/97).

No ano de 1982/83 o maior total de EXC se deu na maturação. No entanto, como ilustra o estrato do BHC (Figura 63), os maiores totais estiveram concentrados no segundo decêndio de maio e de setembro. Nos demais estádios, essa variável esteve abaixo da média no estabelecimento e acima da média no desenvolvimento. Nessas condições hídricas a produtividade teve acréscimo de $10 \%$ maior que sua média (Figura 63, ano 1982/83).

Para os anos agrícolas com os maiores totais de DEF:

Em 1996/97 no estabelecimento registrou-se a maior DEF. Esse ano coincidiu com o maior EXC que ocorreu no desenvolvimento, como descrito anteriormente (Figura 63, ano 1996/97).

No desenvolvimento a maior DEF ocorrida também se deu no ano de 1996/97 (Figura 63, ano 1996/97).

O estádio de Maturação de 1995/96 teve a maior DEF sendo que ao longo dos decêndios esta não ultrapassou $10 \mathrm{~mm}$. Entretanto, no estabelecimento e desenvolvimento ocorreu EXC em todos os decêndios com exceção do último decêndio da fase de desenvolvimento. Nesses dois estádios iniciais do ciclo houve disponibilidade hídrica satisfatória para o bom desenvolvimento vegetativo. A produtividade nessas condições hídricas teve aumento de 24,3\% da média (Figura 63, ano 1995/96).

Em conformidade com Barbosa (2005), a importância desse processo de quantidade e distribuição hídrica foi confirmada com o experimento que revelou que o controle de água no solo, por meio de irrigação, durante o ciclo da cana-de-açúcar mostrou que uma distribuição adequada em cada estágio proporciona aumento na produtividade da cultura (BARBOSA, 2005). 

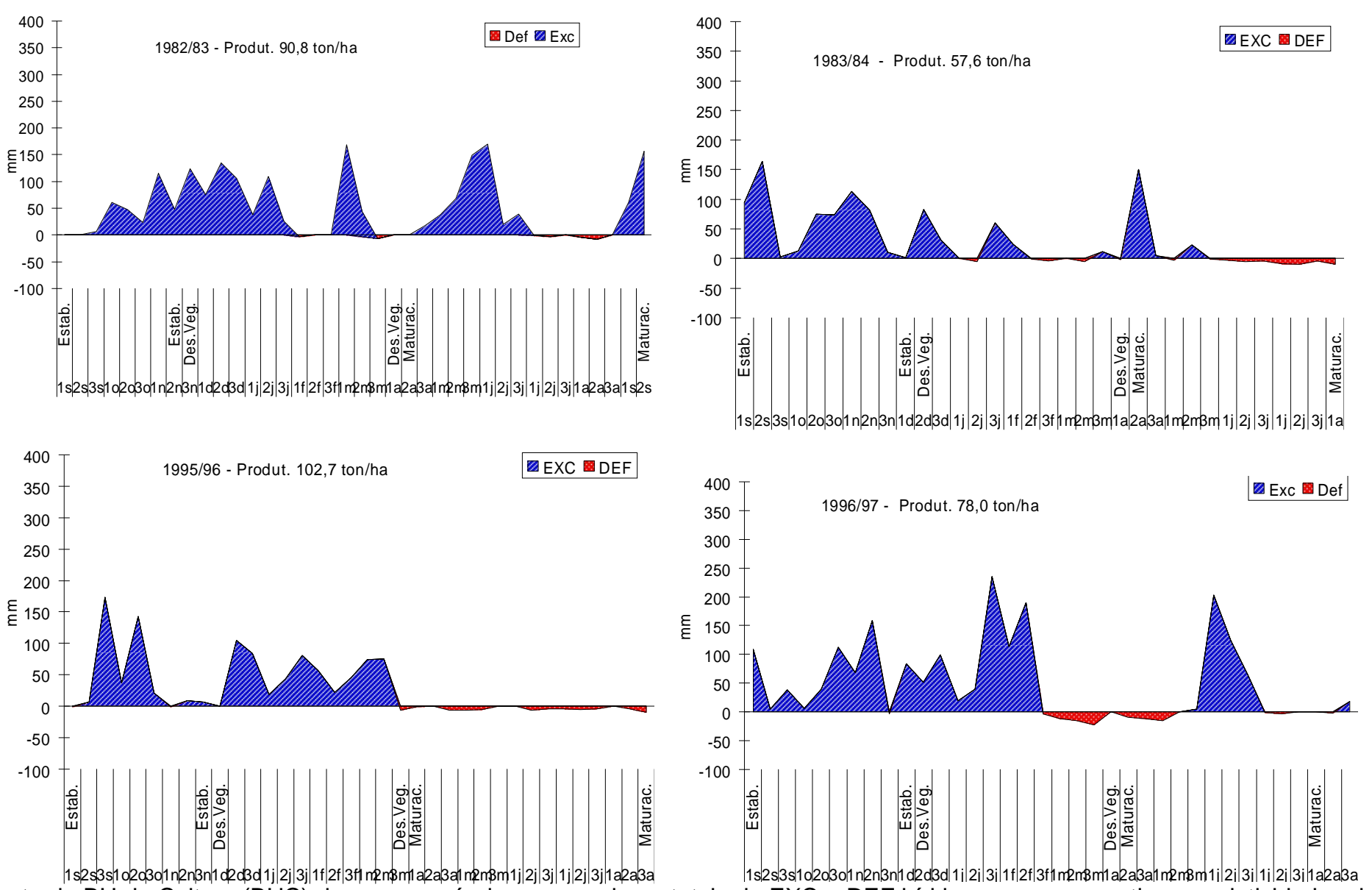

Figura 63 - Extrato do BH de Cultura (BHC) dos anos agrícolas com maiores totais de EXC e DEF hídrica e suas respectivas produtividades do município de Cambé.

Org.: Domingues, I.A.S. (2009). 
- Variabilidade do EXC e DEF pelo extrato do BH de Cultura em Mirador por ordem dos estádios fenológicos

Anos agrícolas com maior EXC:

O estágio de Estabelecimento de 1997/98 teve o maior EXC. O seu desvio em relação à média foi de $274,8 \mathrm{~mm}$ e a DEF zero. No desenvolvimento o EXC ficou $1,28 \%$ abaixo da média e a DEF também esteve abaixo da média em $46,87 \%$. Na maturação houve DEF acima da média no primeiro e terceiro decêndio de setembro Nessas condições hídricas a produtividade foi de 13,25\% acima da média (Figura 64, ano 1997/98);

No ano agrícola de 1996/97 o EXC ocorreu no Desenvolvimento. Houve nesse estádio DEF durante seis decêndios (terceiro fevereiro, segundo e terceiro de março, primeiro de abril e segundo e terceiro de maio). Embora nos 150 dias iniciais do ciclo não ocorreu DEF. No estádio de maturação houve EXC elevado apenas no segundo decêndio de outubro. A produtividade, nessas condições hídricas, foi de 1,96\% maior que a média (Figura 64, ano 1996/97);

O estádio de maturação do ano de 1991/92 teve duração de 19 decêndios, com total de EXC mais elevado ocorrido no terceiro decêndio de abril e maio e primeiro e segundo de setembro. Para os demais estádios só não ocorreu EXC em quatro decêndios, e a condição de DEF foi baixa, não chegando a $30 \mathrm{~mm}$. A produtividade desse ano teve aumento de 1,4\% da média (Figura 64, ano 1991/92).

Para a variável DEF os anos com maiores totais foram por ordem fenológica:

No Estabelecimento do ano de 1985/86 ocorreu a maior DEF (232\% maior que a média), concentrada no último decêndio. No estádio de desenvolvimento houve desvio negativo de DEF e na maturação o desvio foi positivo para essa variável. A produtividade desse ano foi maior que a média em 3,41\% (Figura 64, ano 1985/86);

O estádio de Desenvolvimento de 2004/05 teve maior total de DEF. Deficiência essa, distribuída em dois decêndios, primeiro e terceiro de março. No estabelecimento o EXC esteve $27,8 \%$ acima da média e na maturação abaixo da 
média. Nessa condição hídrica a produtividade teve aumento de 2,4\% da média (Figura 64, ano 2004/05);

Na maturação do ano de 1987/88 aconteceu o maior total de DEF, 76,0\% da soma dos três estádios. Nesse estádio apenas no terceiro decêndio de maio e primeiro de junho houve excedente. Os $24 \%$ restantes de DEF ocorreram no desenvolvimento. Assim, a produtividade foi $7,9 \%$ menor que a média (Figura 64, ano 1987/88).

Diante da análise dos extratos do BH de Cultura dos municípios de Cambé e Mirador, percebeu-se que principalmente longos períodos de tempo com índices hídricos muito desproporcionais (muito acima ou abaixo da média) nos totais das variáveis têm por consequencia a redução da produtividade na cultura da cana-deaçúcar. Resta saber o comportamento da variável térmica por fase fenológica. 


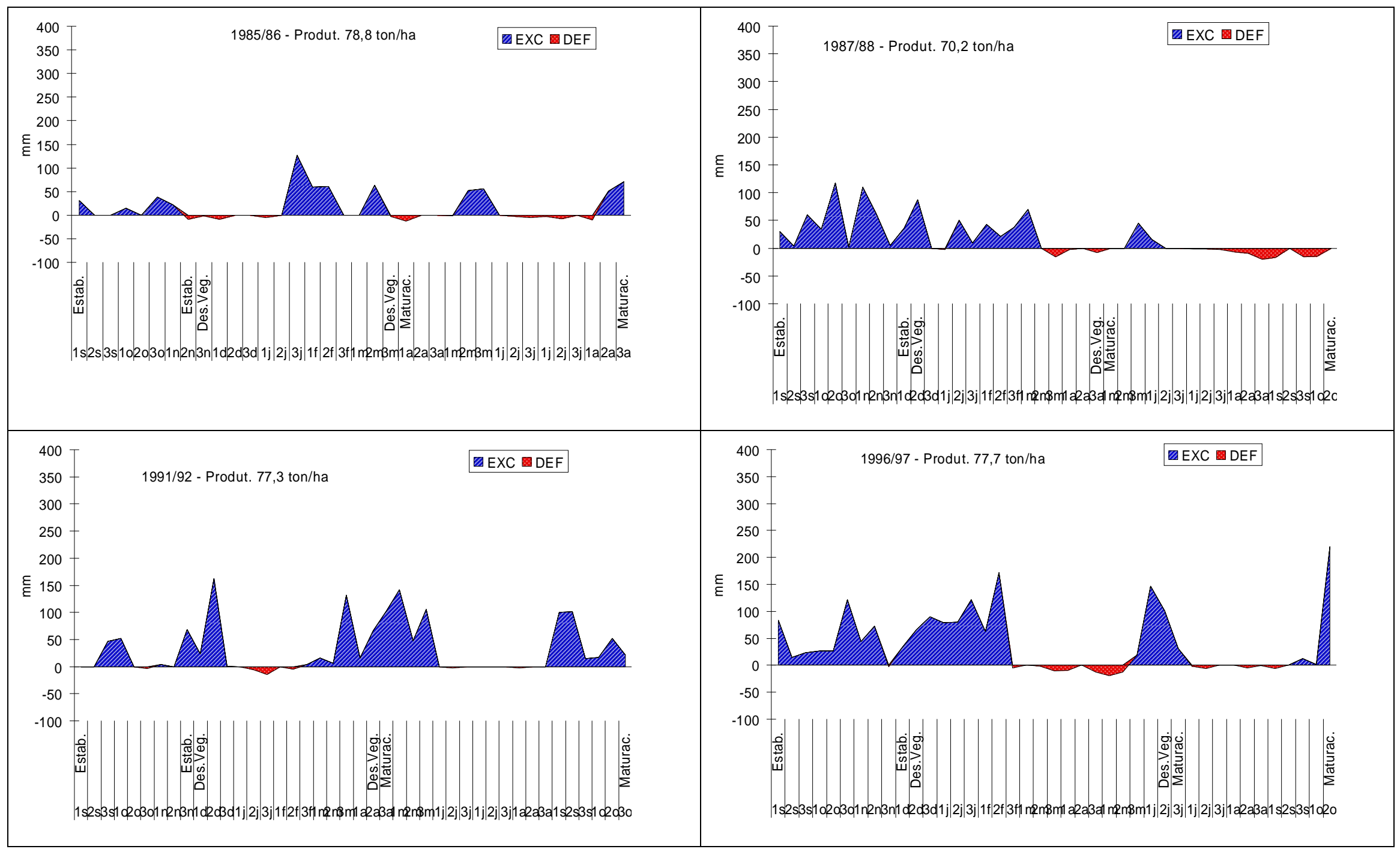

continua... 


\section{continuação}

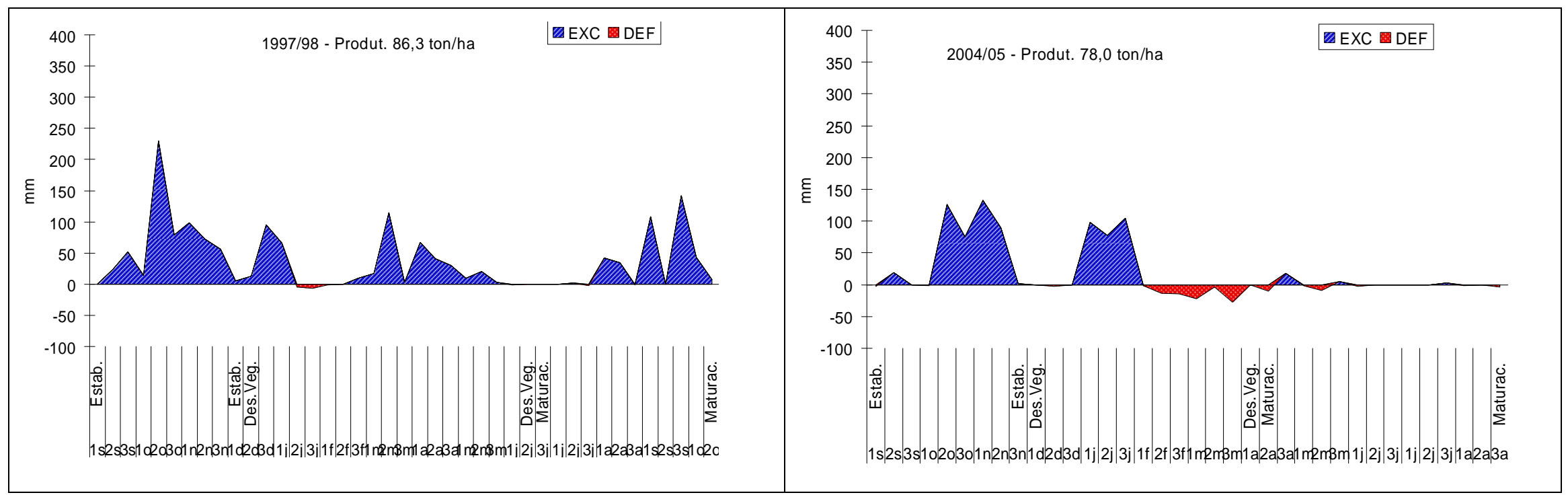

Figura 64 - Extrato do BH de Cultura dos anos agrícolas com desvios máximos de EXC e DEF hídrica e suas respectivas produtividades, município de Mirador, PR.

Org.: Domingues, I.A.S. (2009). 
4.7.5 - Análise da variabilidade térmica e a produtividade da cultura da cana-deaçúcar nos municípios de Cambé e Mirador, PR

O comportamento da variabilidade térmica sobre a produtividade da cana-deaçúcar foi abordado em escalas temporais anuais e decendiais por fase fenológica da cultura, com o objetivo de medir a correlação dessas variáveis.

4.7.5.1 - Análise dos dados anuais de temperatura e produtividade:

A série temporal de 25 anos, dos anos agrícolas de 1981/82 a 2005/06, apresentou média anual da temperatura do ar de $21,2^{\circ} \mathrm{C}$ em Cambé e de $22,3^{\circ} \mathrm{C}$ em Mirador. A temperatura do ar do primeiro município é, portanto, mais reduzida que a do segundo em $1,1^{\circ} \mathrm{C}$ de temperatura (Tabela 25 ).

Analisando o comportamento da temperatura do ar ao longo da série percebeu-se que, quanto aos extremos, a mais elevada temperatura média anual ocorreu no ano agrícola de 2001/02, sendo de 22,0ำ em Cambé e de $23,1^{\circ} \mathrm{C}$ em Mirador. As mais reduzidas ocorreram em 1989/90 (20,4ํㅡ em Cambé e 21,5ํㅡ em Mirador) e em 1992/93 (21,5ํ em Mirador) (Tabela 25).

\subsubsection{1 - Quanto à temperatura do ar e à duração do ciclo da cultura}

Para a série estudada, no ano em que a temperatura foi mais elevada, o ciclo teve duração mais curta e no ano com temperatura mais reduzida a duração do ciclo se alongou (Tabela 25).

A média anual de decêndios foi de 35,1 em Cambé e de 40,6 em Mirador. O ano agrícola com o menor número de decêndios nesses municípios ocorreu em 2001/02, com 28 e 35 decêndios, com as maiores temperaturas ocorridas. O maior número de decêndios se deu em 1989/90 em Cambé, com 40 decêndios. Em Mirador houve dois anos agrícolas, 1989/90 e 1992/93, com 44 decêndios cada uma e, em decorrência, as mais reduzidas temperaturas (Tabela 25) 
4.7.5.1.2 - Quanto à correlação e desvio entre a temperatura média anual e a produtividade

O coeficiente de correlação entre essas variáveis foi de $r=-0,1$ em Cambé e de $r=0,1$ em Mirador, considerada fraca (Figura 65). Pelo teste $t$ de Student a nível de significância de 0,10 (90\%) a correlação não foi significativa, sendo $t(n-1)=0,5$ no primeiro município e $\mathrm{t}(\mathrm{n}-1)=0,7$ no segundo município (Tabela 25). O gráfico de dispersão confirma esses valores quando apresenta nuvem de pontos dispersa (Figura 65).

Tabela 25 - Dados de temperatura, produtividade, duração do ciclo da cultura da cana-de-açúcar por decêndio (Dec) e seus desvios em relação à média nos municípios de Cambé e Mirador, ano agrícola $1981 / 82$ a 2005/06.

\begin{tabular}{|c|c|c|c|c|c|c|c|c|c|c|c|c|}
\hline \multicolumn{7}{|c|}{ CAMBÉ } & \multicolumn{6}{|c|}{ MIRADOR } \\
\hline $\begin{array}{c}\text { Ano } \\
\text { agrícola }\end{array}$ & $\begin{array}{l}\text { Duração } \\
\text { ciclo } \\
\text { (Dec) }\end{array}$ & $d_{i}$ & $\begin{array}{l}\text { Temp } \\
\text { Méd } \\
\text { (o C) } \\
\end{array}$ & $\mathrm{d}_{\mathrm{i}}$ & \begin{tabular}{|l}
$\begin{array}{l}\text { Produt } \\
\text { (ton/ha) }\end{array}$ \\
\end{tabular} & $\mathrm{d}_{\mathrm{i}}$ & $\begin{array}{l}\text { Duração } \\
\text { ciclo } \\
\text { (Dec) }\end{array}$ & $d_{i}$ & $\begin{array}{l}\text { Temp } \\
\text { Méd } \\
\text { (o C) } \\
\end{array}$ & $\mathrm{d}_{\mathrm{i}}$ & \begin{tabular}{|l} 
Produt \\
(ton/ha)
\end{tabular} & $d_{i}$ \\
\hline $1981 / 82$ & 38 & 2,9 & 20,7 & $-0,4$ & 115,6 & 33,2 & 42 & 1,4 & 22,0 & $-0,2$ & 78,1 & 1,9 \\
\hline $1982 / 83$ & 38 & 2,9 & 20,9 & $-0,2$ & 90,8 & 8,4 & 44 & 3,4 & 21,9 & $-0,3$ & 79,5 & 3,3 \\
\hline $1983 / 84$ & 34 & - & 21,1 & 0,0 & 57,6 & $-24,8$ & 41 & 0,4 & 22,2 & 0,0 & 62,4 & $-13,8$ \\
\hline $1984 / 85$ & 37 & 1,9 & 20,9 & $-0,2$ & 68,9 & $-13,5$ & 41 & 0,4 & 22,0 & $-0,2$ & 79,1 & 2,9 \\
\hline $1985 / 86$ & 30 & - & 21,6 & 0,5 & 80,7 & $-1,8$ & 36 & $-4,6$ & 22,9 & 0,7 & 78,8 & 2,6 \\
\hline $1986 / 87$ & 38 & 2,9 & 20,8 & $-0,3$ & 79,2 & $-3,2$ & 43 & 2,4 & 22,0 & $-0,2$ & 73,6 & $-2,6$ \\
\hline $1987 / 88$ & 37 & 1,9 & 20,8 & $-0,3$ & 78,6 & $-3,8$ & 41 & 0,4 & 22,0 & $-0,2$ & 70,2 & $-6,0$ \\
\hline $1988 / 89$ & 39 & 3,9 & 20,7 & $-0,4$ & 66,4 & $-16,0$ & 44 & 3,4 & 21,8 & $-0,4$ & 89,0 & 12,8 \\
\hline $1989 / 90$ & 40 & 4,9 & 20,4 & $-0,7$ & 68,9 & $-13,5$ & 44 & 3,4 & 21,5 & $-0,7$ & 68,0 & $-8,2$ \\
\hline $1990 / 91$ & 36 & 0,9 & 21,0 & $-0,1$ & 81,3 & $-1,1$ & 41 & 0,4 & 22,2 & 0,0 & 67,4 & $-8,8$ \\
\hline $1991 / 92$ & 37 & 1,9 & 20,9 & $-0,2$ & 97,6 & 15,2 & 42 & 1,4 & 22,1 & $-0,1$ & 77,3 & 1,1 \\
\hline $1992 / 93$ & 38 & 2,9 & 20,8 & $-0,3$ & 83,0 & 0,6 & 44 & 3,4 & 21,5 & $-0,7$ & 76,8 & 0,6 \\
\hline $1993 / 94$ & 35 & - & 21,3 & 0,2 & 74,9 & $-7,5$ & 39 & $-1,6$ & 22,3 & 0,1 & 80,5 & 4,3 \\
\hline $1994 / 95$ & 32 & - & 21,3 & 0,2 & 90,2 & 7,8 & 36 & $-4,6$ & 22,9 & 0,7 & 96,2 & 20,0 \\
\hline $1995 / 96$ & 36 & 0,9 & 21,0 & $-0,1$ & 102,7 & 20,3 & 42 & 1,4 & 22,0 & $-0,2$ & 84,7 & 8,5 \\
\hline $1996 / 97$ & 36 & 0,9 & 21,0 & $-0,1$ & 78,0 & $-4,4$ & 41 & 0,4 & 22,0 & $-0,2$ & 77,7 & 1,5 \\
\hline $1997 / 98$ & 33 & - & 21,4 & 0,3 & 87,6 & 5,2 & 41 & 0,4 & 22,3 & 0,1 & 86,3 & 10,1 \\
\hline $1998 / 99$ & 37 & 1,9 & 20,9 & $-0,2$ & 89,2 & 6,8 & 42 & 1,4 & 21,9 & $-0,3$ & 77,1 & 0,9 \\
\hline $1999 / 00$ & 37 & 1,9 & 20,9 & $-0,2$ & 78,8 & $-3,6$ & 41 & 0,4 & 22,0 & $-0,2$ & 54,3 & $-21,9$ \\
\hline $2000 / 01$ & 33 & - & 21,5 & 0,4 & 91,1 & 8,7 & 39 & $-1,6$ & 22,5 & 0,3 & 68,4 & $-7,8$ \\
\hline $2001 / 02$ & 28 & - & 22,0 & 0,9 & 75,2 & $-7,2$ & 35 & $-5,6$ & 23,1 & 0,9 & 76,2 & 0,0 \\
\hline $2002 / 03$ & 29 & - & 21,6 & 0,5 & 102,8 & 20,4 & 39 & $-1,6$ & 22,7 & 0,5 & 65,2 & $-11,0$ \\
\hline $2003 / 04$ & 37 & 1,9 & 20,8 & $-0,3$ & 88,8 & 6,4 & 41 & 0,4 & 22,0 & $-0,2$ & 80,2 & 4,0 \\
\hline $2004 / 05$ & 29 & - & 21,9 & 0,8 & 58,0 & $-24,4$ & 36 & $-4,6$ & 23,0 & 0,8 & 78,0 & 1,8 \\
\hline $2005 / 06$ & 34 & - & 21,2 & 0,1 & 74,3 & $-8,1$ & 41 & 0,4 & 22,3 & 0,1 & 81,2 & 5,0 \\
\hline Média & 35,1 & & 21,1 & & 82,4 & & 40,6 & & 22,2 & & 76,2 & \\
\hline$r$ & & 0,1 & & $-0,1$ & & & & $-0,1$ & & 0,1 & & \\
\hline$t(n-1)$ & & & & 0,5 & & & & & & 0,7 & & \\
\hline
\end{tabular}

Org.: Domingues, I.A.S. (2009). 

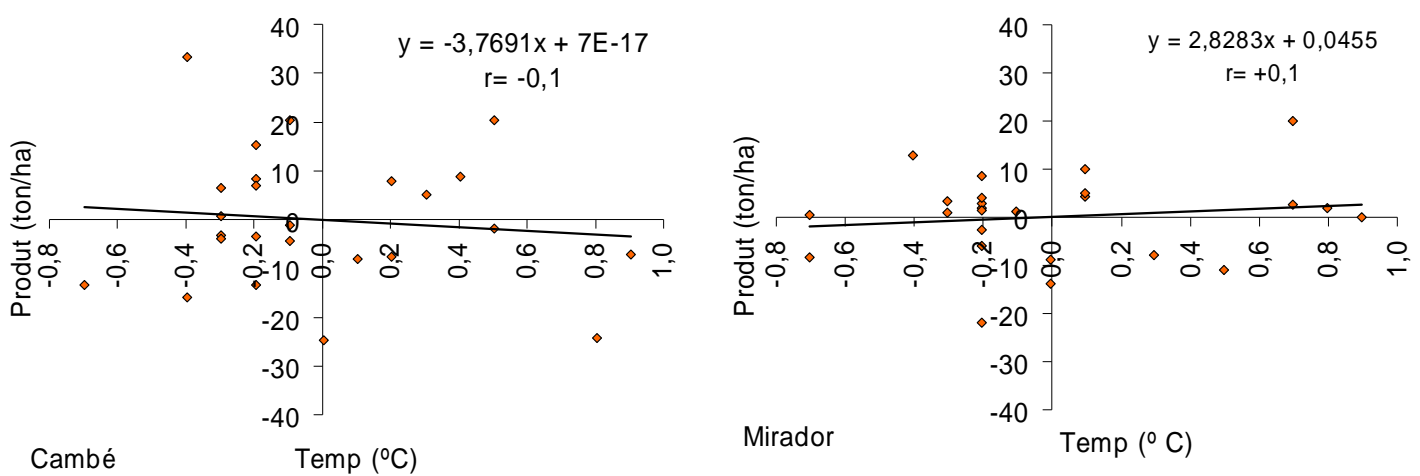

Figura 65 - Correlação da temperatura média anual com a produtividade da cana-de-açúcar nos municípios de Cambé e Mirador, ano agrícola de 1982/83 a 2005/06.

Org.: Domingues, I.A.S. (2009).

Corroborando esses resultados de correlação, verificou-se também que os desvios das variáveis em relação à média para os dois municípios revelaram baixa representatividade, menos de $50 \%$ da variável independente (temperatura), variando para mais (ou para menos) e consequentemente a variável dependente (produtividade) também teve variação positiva (ou negativa) (Figura 66).
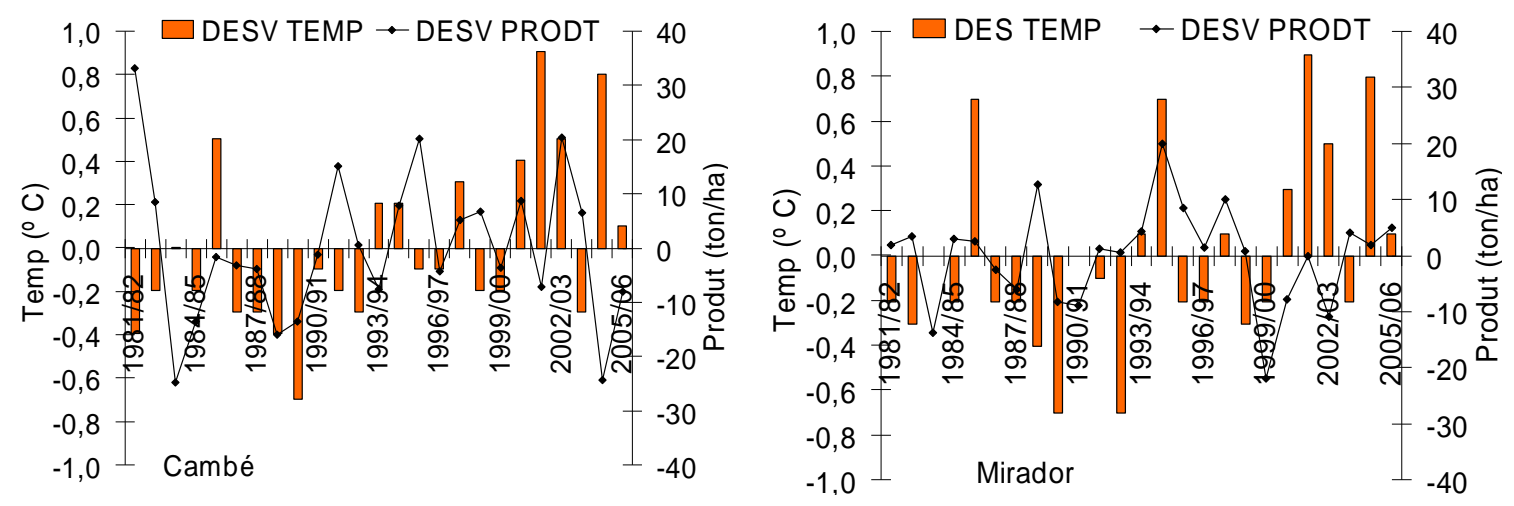

Figura 66 - Desvio de temperatura média anual e de produtividade da cana-de-açúcar para os municípios de Cambé e Mirador, período de 1981/82 a 2005/2006.

Org.: Domingues, I.A.S. (2009). 


\subsubsection{2 - Análise por estádio fenológico da variável temperatura e produtividade}

Os dados da variável térmica e da produtividade foram analisados também por estádio fenológico da cultura (Tabela 26).

-As temperaturas por estádios fenológicos tiveram as seguintes médias no período:

Em Cambé o primeiro estádio do ciclo teve média de $21,7^{\circ} \mathrm{C}$, o segundo de $23,8^{\circ} \mathrm{C}$ e o terceiro de $18,9^{\circ} \mathrm{C}$. Em Mirador as médias foram de $22,9^{\circ} \mathrm{C}, 24,4^{\circ} \mathrm{C}$ e $20,0^{\circ} \mathrm{C}$, respectivamente. As temperaturas médias, portanto, são mais elevadas no município de Mirador, apresentando a maior diferença no estádio de estabelecimento (Tabela 26).

-Quanto aos desvios anuais de temperatura e produtividade em relação à média de cada uma das fases:

Em Cambé - O estabelecimento apresentou desvios extremos de temperatura nos anos de 1989/90 e 1994/95. Seus valores foram de 1,2 abaixo da média e produtividade também abaixo da média e de 1,1 acima da média e produtividade acima da média, respectivamente (Figura 67, A1). No desenvolvimento vegetativo os desvios ocorreram nos anos de 1981/82 (-1,2) e em $1997 / 98(+0,9)$, os desvios de produtividade foram positivos, ou seja, acima da média nos dois anos agrícolas (Figura 67, A2); e na maturação os extremos foram de -1,3 em 1989/90 e de +3,5 em 2000/01 e produtividades negativas, ou seja, abaixo da média (Figura 67, A3).

No município de Mirador, no estabelecimento, houve dois anos com desvios extremos, 1983/84 e 1989/90, com valores negativos de -1,1 cada um (desvio de produtividade negativa) e o ano de 1994/95 com desvio positivo de 1,2 (desvio produtividade positiva) (Figura 67, B1). No desenvolvimento vegetativo o ano com extremo de desvio negativo foi 1981/82, com 1,1, e com desvios positivos os anos de 1985/86 e 2004/05, com 1,1. Para esses anos o desvio de produtividade foi positivo (Figura 67, B2). Na maturação os extremos foram nos anos 1988/89, com desvio de -0,9 (desvio produtividade positivo) e 2001/02, com +1,1 (sem desvio de produtividade) (Figura 67, B3). 
Tabela 26 - Dados de temperatura por estádio fenológico e de produtividade da cana-de-açúcar, desvios em relação à média e correlação, para Cambé e Mirador, ano agrícola 1981/82 a 2005/06.

\begin{tabular}{|c|c|c|c|c|c|c|c|c|}
\hline \multicolumn{9}{|c|}{ CAMBÉ } \\
\hline \multicolumn{9}{|c|}{ TEMPERATURA (으) POR ESTÁDIOS FENOLÓGICOS } \\
\hline $\begin{array}{l}\text { Ano } \\
\text { agrícola }\end{array}$ & ESTAB & $\mathrm{d}_{\mathrm{i}}$ & $\begin{array}{l}\text { DESENV } \\
\text { VEG }\end{array}$ & $\mathrm{d}_{\mathrm{i}}$ & MATUR & $\mathrm{d}_{\mathrm{i}}$ & $\begin{array}{l}\text { PRODUT } \\
\text { (ton/ha) }\end{array}$ & $\mathrm{d}_{\mathrm{i}}$ \\
\hline $1981 / 82$ & 21,3 & $-0,4$ & 22,6 & $-1,2$ & 18,5 & $-0,4$ & 115,6 & 33,2 \\
\hline $1982 / 83$ & 21,4 & $-0,3$ & 23,0 & $-0,8$ & 18,1 & $-0,8$ & 90,8 & 8,4 \\
\hline $1983 / 84$ & 20,7 & $-1,0$ & 24,2 & 0,4 & 19,3 & 0,4 & 57,6 & $-24,8$ \\
\hline $1984 / 85$ & 21,9 & 0,2 & 23,4 & $-0,4$ & 18,1 & $-0,8$ & 68,9 & $-13,5$ \\
\hline $1985 / 86$ & 22,2 & 0,6 & 24,6 & 0,8 & 20,2 & 1,3 & 80,7 & $-1,8$ \\
\hline $1986 / 87$ & 21,4 & $-0,3$ & 23,3 & $-0,5$ & 18,1 & $-0,8$ & 79,2 & $-3,2$ \\
\hline $1987 / 88$ & 21,5 & $-0,2$ & 23,9 & 0,1 & 18,2 & $-0,8$ & 78,6 & $-3,8$ \\
\hline $1988 / 89$ & 22,1 & 0,4 & 23,2 & $-0,6$ & 17,9 & $-1,0$ & 66,4 & $-16,0$ \\
\hline $1989 / 90$ & 20,5 & $-1,2$ & 24,0 & 0,2 & 17,6 & $-1,3$ & 68,9 & $-13,5$ \\
\hline $1990 / 91$ & 21,4 & $-0,3$ & 23,5 & $-0,3$ & 18,6 & $-0,3$ & 81,3 & $-1,1$ \\
\hline $1991 / 92$ & 21,7 & 0,0 & 23,8 & 0,0 & 18,0 & $-0,9$ & 97,6 & 15,2 \\
\hline $1992 / 93$ & 21,0 & $-0,7$ & 23,4 & $-0,4$ & 18,3 & $-0,6$ & 83,0 & 0,6 \\
\hline $1993 / 94$ & 22,1 & 0,4 & 23,7 & $-0,1$ & 18,9 & 0,0 & 74,9 & $-7,5$ \\
\hline $1994 / 95$ & 22,8 & 1,1 & 23,9 & 0,1 & 19,3 & 0,3 & 90,2 & 7,8 \\
\hline $1995 / 96$ & 21,4 & $-0,3$ & 23,8 & 0,0 & 18,5 & $-0,4$ & 102,7 & 20,3 \\
\hline $1996 / 97$ & 21,5 & $-0,2$ & 23,7 & $-0,1$ & 18,5 & $-0,4$ & 78,0 & $-4,4$ \\
\hline $1997 / 98$ & 22,3 & 0,6 & 24,7 & 0,9 & 18,7 & $-0,2$ & 87,6 & 5,2 \\
\hline $1998 / 99$ & 22,1 & 0,4 & 24,0 & 0,2 & 18,5 & $-0,5$ & 89,2 & 6,8 \\
\hline $1999 / 00$ & 21,5 & $-0,2$ & 23,9 & 0,1 & 18,1 & $-0,8$ & 78,8 & $-3,6$ \\
\hline $2000 / 01$ & 22,2 & 0,5 & 24,0 & 0,2 & 19,1 & 0,2 & 91,1 & 8,7 \\
\hline $2001 / 02$ & 22,0 & 0,3 & 24,1 & 0,3 & 22,4 & 3,5 & 75,2 & $-7,2$ \\
\hline $2002 / 03$ & 22,4 & 0,7 & 24,6 & 0,8 & 20,8 & 1,9 & 102,8 & 20,4 \\
\hline $2003 / 04$ & 21,6 & $-0,1$ & 23,7 & $-0,1$ & 18,4 & $-0,5$ & 88,8 & 6,4 \\
\hline $2004 / 05$ & 21,9 & 0,2 & 24,1 & 0,3 & 21,7 & 2,8 & 58,0 & $-24,4$ \\
\hline $2005 / 06$ & 21,3 & $-0,3$ & 23,9 & 0,1 & 19,1 & 0,1 & 74,3 & $-8,1$ \\
\hline Média & 21,7 & & 23,8 & & 18,9 & & 82,4 & \\
\hline Correl & & 0,19 & & $-0,18$ & & $-0,15$ & & \\
\hline$t(n-1)$ & 0,93 & & 0,88 & & 0,78 & & & \\
\hline \multicolumn{9}{|c|}{ MIRADOR } \\
\hline $1981 / 82$ & 22,6 & $-0,2$ & 23,1 & $-1,3$ & 20,4 & 0,4 & 78,1 & 1,9 \\
\hline $1982 / 83$ & 22,6 & $-0,2$ & 24,0 & $-0,4$ & 19,5 & $-0,5$ & 79,5 & 3,3 \\
\hline $1983 / 84$ & 21,9 & $-1,0$ & 24,5 & 0,2 & 20,3 & 0,3 & 62,4 & $-13,8$ \\
\hline $1984 / 85$ & 23,2 & 0,4 & 24,4 & 0,0 & 19,8 & $-0,3$ & 79,1 & 2,9 \\
\hline $1985 / 86$ & 23,7 & 0,9 & 25,5 & 1,1 & 20,2 & 0,2 & 78,8 & 2,6 \\
\hline $1986 / 87$ & 22,8 & $-0,1$ & 24,3 & 0,0 & 19,6 & $-0,4$ & 73,6 & $-2,6$ \\
\hline $1987 / 88$ & 22,6 & $-0,2$ & 24,7 & 0,3 & 20,0 & 0,0 & 70,2 & $-6,0$ \\
\hline $1988 / 89$ & 23,3 & 0,4 & 24,1 & $-0,3$ & 19,1 & $-0,9$ & 89,0 & 12,8 \\
\hline $1989 / 90$ & 21,9 & $-1,0$ & 23,9 & $-0,4$ & 19,6 & $-0,5$ & 68,0 & $-8,2$ \\
\hline $1990 / 91$ & 22,7 & $-0,2$ & 24,3 & $-0,1$ & 20,1 & 0,1 & 67,4 & $-8,8$ \\
\hline $1991 / 92$ & 23,3 & 0,5 & 24,5 & 0,1 & 19,4 & $-0,6$ & 77,3 & 1,1 \\
\hline $1992 / 93$ & 22,2 & $-0,7$ & 22,2 & $-2,1$ & 20,7 & 0,7 & 76,8 & 0,6 \\
\hline $1993 / 94$ & 23,1 & 0,2 & 24,1 & $-0,2$ & 20,4 & 0,3 & 80,5 & 4,3 \\
\hline $1994 / 95$ & 24,0 & 1,2 & 24,8 & 0,4 & 20,4 & 0,4 & 96,2 & 20,0 \\
\hline $1995 / 96$ & 22,5 & $-0,4$ & 24,0 & $-0,4$ & 19,7 & $-0,3$ & 84,7 & 8,5 \\
\hline $1996 / 97$ & 22,5 & $-0,3$ & 23,6 & $-0,7$ & 20,1 & 0,1 & 77,7 & 1,5 \\
\hline $1997 / 98$ & 23,4 & 0,5 & 25,1 & 0,7 & 19,6 & $-0,4$ & 86,3 & 10,1 \\
\hline $1998 / 99$ & 22,6 & $-0,3$ & 24,0 & $-0,3$ & 20,0 & 0,0 & 77,1 & 0,9 \\
\hline $1999 / 00$ & 22,8 & 0,0 & 24,7 & 0,3 & 19,6 & $-0,4$ & 54,3 & $-21,9$ \\
\hline $2000 / 01$ & 23,2 & 0,3 & 24,9 & 0,5 & 20,1 & 0,0 & 68,4 & $-7,8$ \\
\hline $2001 / 02$ & 23,2 & 0,4 & 25,0 & 0,6 & 21,1 & 1,1 & 76,2 & 0,0 \\
\hline $2002 / 03$ & 23,2 & 0,3 & 25,3 & 0,9 & 20,0 & 0,0 & 65,2 & $-11,0$ \\
\hline $2003 / 04$ & 22,9 & 0,0 & 24,8 & 0,5 & 19,7 & $-0,4$ & 80,2 & 4,0 \\
\hline $2004 / 05$ & 23,2 & 0,3 & 25,4 & 1,1 & 20,6 & 0,6 & 78,0 & 1,8 \\
\hline $2005 / 06$ & 22,2 & $-0,7$ & 23,7 & $-0,7$ & 20,6 & 0,6 & 81,2 & 5,0 \\
\hline Média & 22,9 & & 24,4 & & 20,0 & & 76,2 & \\
\hline$r$ & & 0,44 & & $-0,11$ & & 0,03 & & \\
\hline$t(n-1)$ & 2,12 & & 0,54 & & 0,17 & & & \\
\hline
\end{tabular}

Org. Domingues, I.A.S. (2009). 

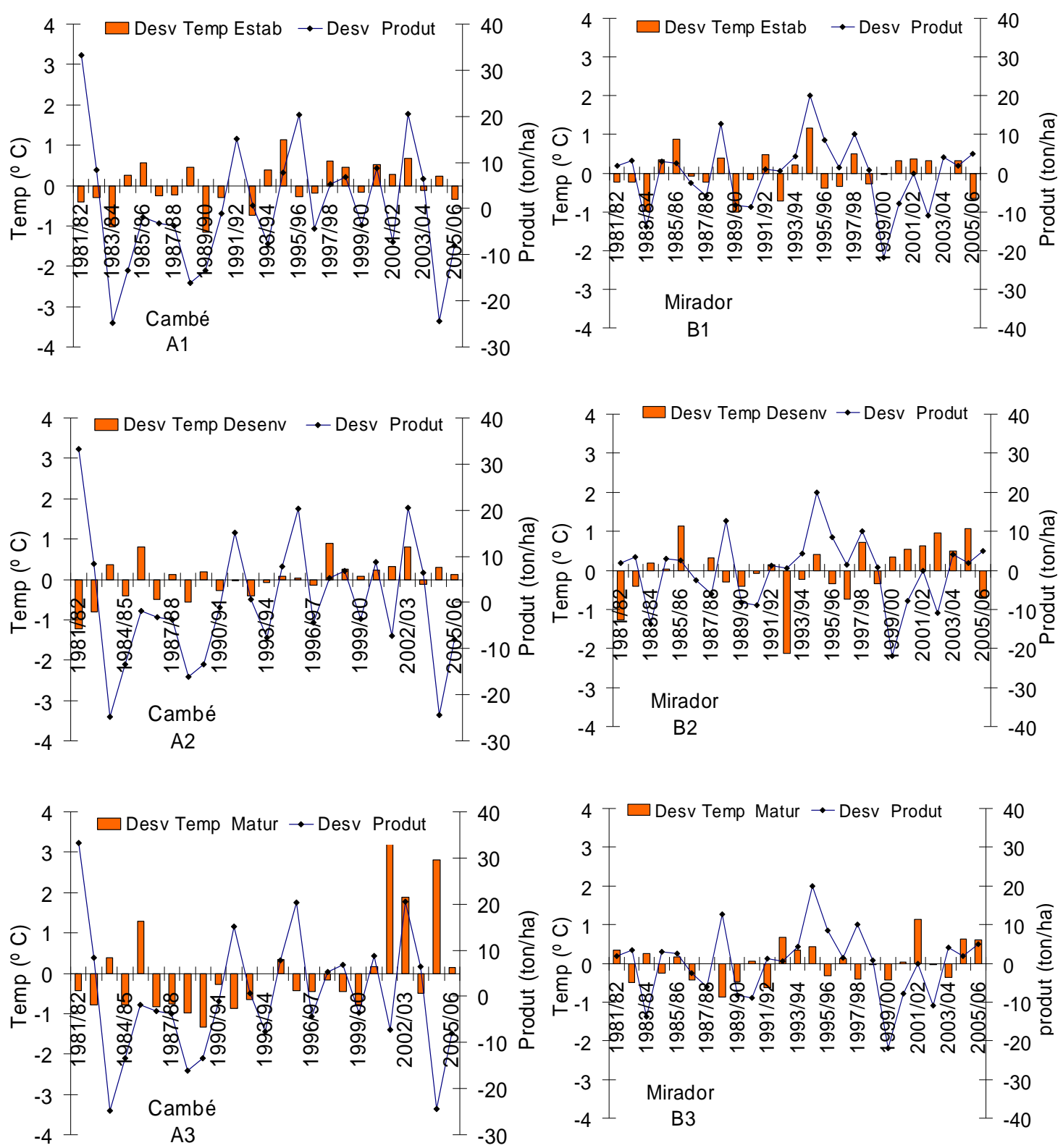

Figura 67 - Desvios de temperatura por estádios fenológicos e de produtividade nos municípios de Cambé e Mirador, ano agrícola de 1981/82 a 2005/06.

Org.: Domingues, I.A.S. (2009). 
4.7.5.3 - Análise de correlação das variáveis temperatura e produtividade por estádio fenológico

A correlação entre a temperatura e a produtividade apresentou, no estabelecimento, coeficiente de $r=0,4$ em Mirador, considerada com grau de correlação moderada. Nos demais estádios a correlação foi considerada de grau fraco (Figura 68, Tabela 26). O gráfico de dispersão, por apresentar a nuvem de pontos distribuída de forma dispersa, confirma a baixa correlação existente entre temperatura e produtividade (Figura 68).

Por meio do teste $t$ de Student constata-se correlação significativa entre temperatura e produtividade da cana-de-açúcar apenas no estádio de estabelecimento a nível de $5 \%$ de significância, ou $95 \%$ de probabilidade, em Mirador (Tabela 26). 

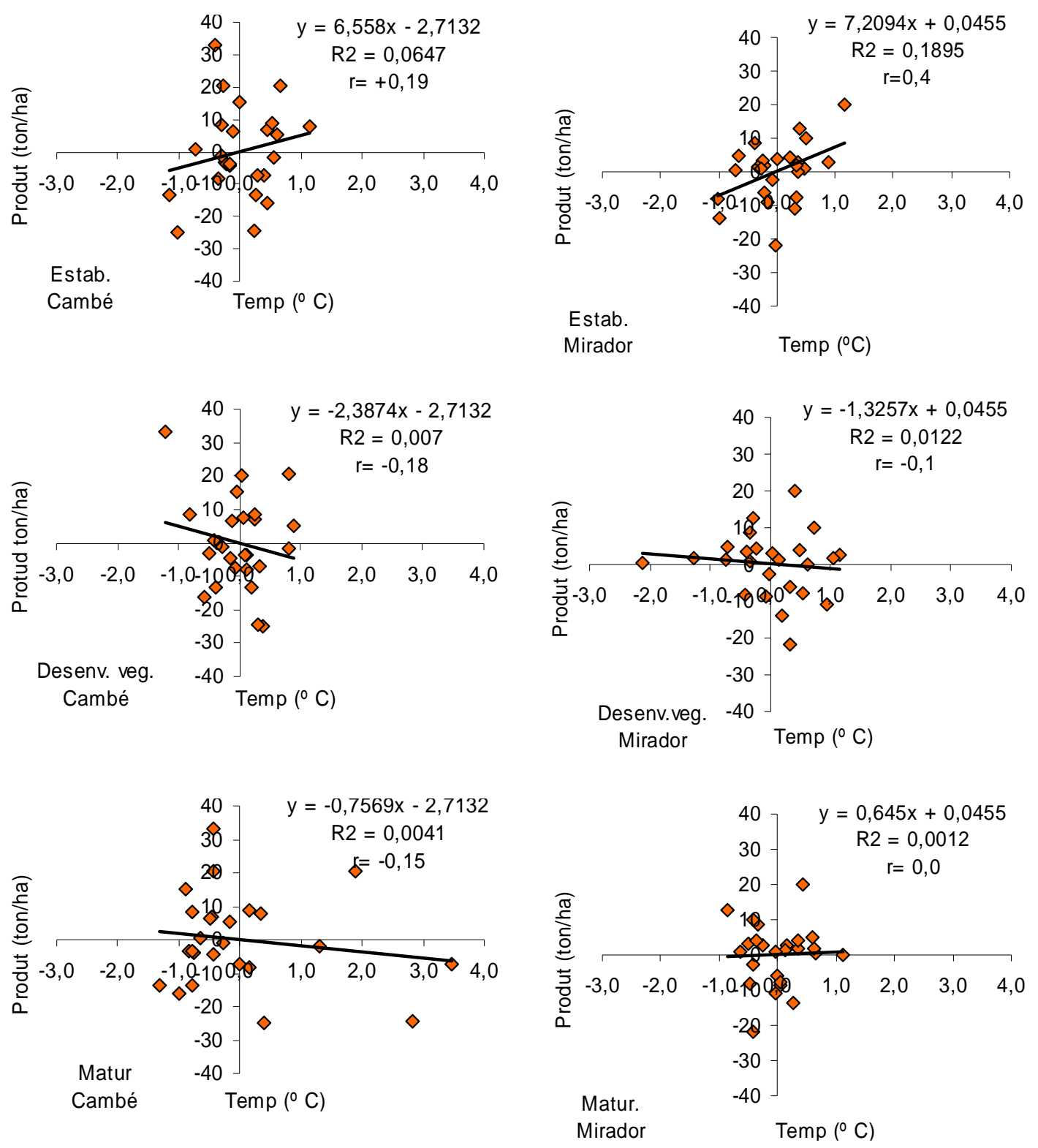

Figura 68 - Correlação e dispersão por estágio fenológico entre temperatura e produtividade dos municípios de Cambé e Mirador, ano agrícola de 1981/82 a 2005/06.

Org.: Domingues, I.A.S. (2009).

4.7.6 - Análise de correlação das variáveis chuva, temperatura, EXC, DEF e produtividade por episódios ENOS

Sendo o fenômeno El Niño Oscilação-Sul (ENOS) uma variável consideravelmente influente na variabilidade do clima, utilizou-se o período de tempo 
estudado em anos classificados como El Niño (1982/83, 1986/87, 1987/88, 1991/92, 1992/93, 1993/94, 1994/95, 1997/98, 2002/03 e 2004/05), La Niña (1988/89, 1995/96, 1998/99, 1999/00) e Neutros (1981/82, 1983/84, 1985/86, 1989/90, 1990/91, 1996/97, 2000/01, 2001/02, 2003/04 e 2005/06). Teve-se, portanto, dentro dos 25 anos do período, dez anos de episódios El Niño, cinco de La Niña e dez Neutros. Estudos de séries históricas por períodos de anos ENOS têm sido utilizados para várias culturas, inclusive da cana-de-açúcar (ROSSIN, 2009; BERLATO et al. (2005); ALBERTO (2005); PODESTÁ (1999)).

A análise de correlação para as variáveis chuva, temperatura, EXC e DEF (BH Normal, BH Sequêncial e BH Cultura) e produtividade foi efetuada para cada um dos eventos ENOS. Lembre-se que o sinal positivo do coeficiente de correlação indica que aumento em uma variável corresponde a aumento na outra e o sinal negativo que as variáveis variam em sentidos opostos. Essas variáveis climáticas, de acordo com tais eventos, foram também analisadas por estádios fenológicos da cultura estudada (Tabelas 27, 28 e 29). Reuniram-se também nessas três tabelas dados dessas variáveis já analisados nos itens anteriores (4.7.1 a 4.7.5), para os 25 anos do período.

\section{- Chuva e temperatura para os anos de ENOS}

A correlação entre chuva e produtividade (Tabela 27, clima e produtividade) apresentou forte e moderada correlação em ano de La Niña para Cambé e Mirador com coeficiente de correlação de $r=0,84$ e $r=0,64$, respectivamente. Tais correlações foram confirmadas pelo teste $t$ de Student a nível de significância de $5 \%$ e $10 \%$, obtendo-se valor de $t_{n-1}=3.085$ e $t_{n-1=1,667}$. Para a temperatura e produtividade houve também correlação em anos de La Niña no município de Cambé com coeficientes de $r=0.83$, sendo esta considerada forte correlação, confirmada a nível de significância de $5 \%$ com $t_{n-1}=2.976$.

Essas correlações indicam que, durante esse episódio, aumentando o total de chuva e/ou temperatura, aumenta a produtividade da cana-de-açúcar, evidenciando a importância do total de chuva para o ciclo produtivo da cultura. De acordo com Guerra e Caramori (2003), a influência do ENOS sobre a precipitação traz impactos positivos e/ou negativos na produtividade das culturas. 
Tabela 27 - Correlação $(r)$ e teste $t$ Student entre temperatura, chuva e produtividade para período de 25 anos e por BH Normal e Sequencial por estádios fenológicos (EXC e DEF) e estes por anos de ENOS, série de anos 1981/82 a 2005/06, para Cambé e Mirador, PR.

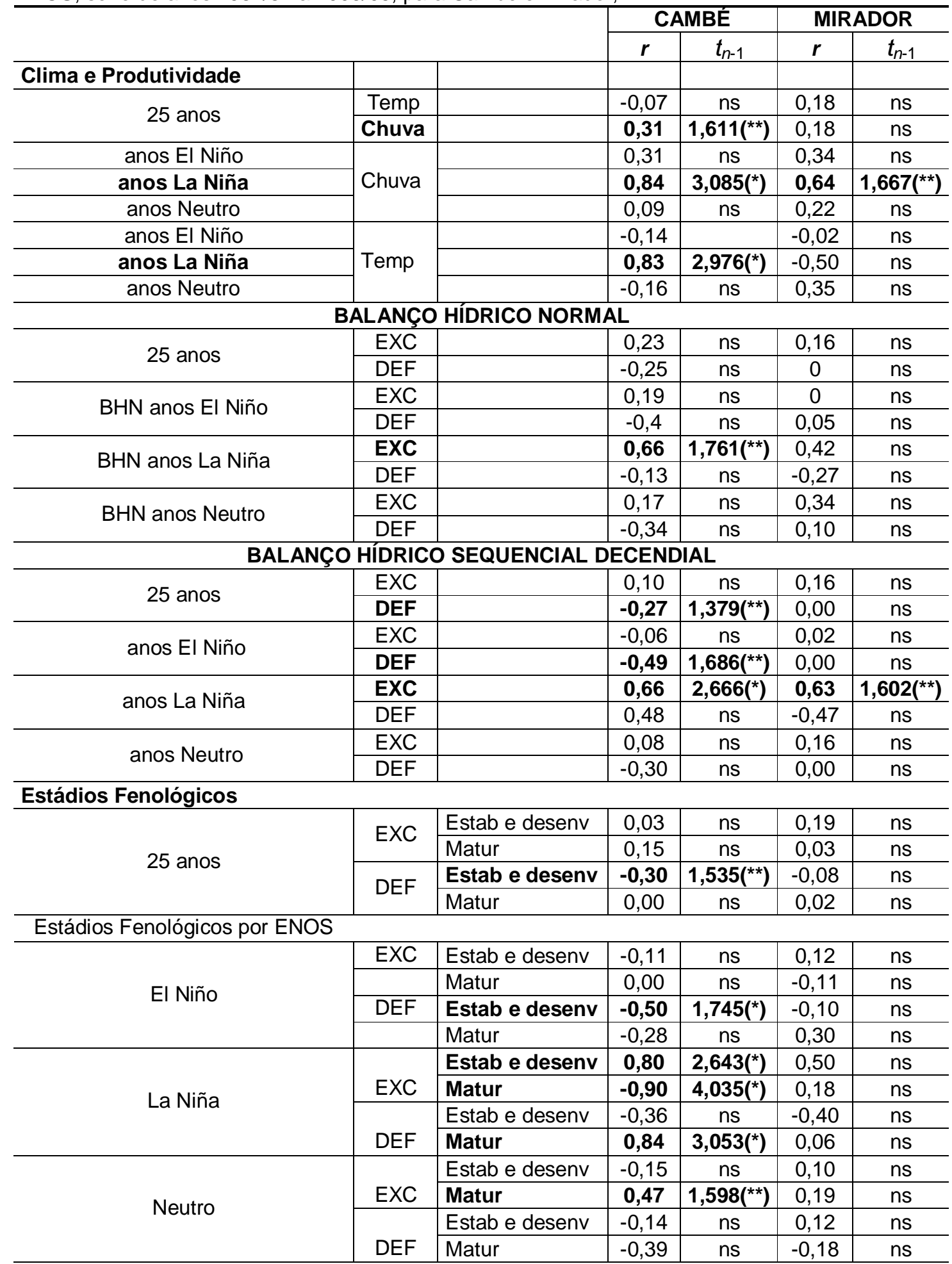

ns (não-significativo), $\left({ }^{*}\right)$ significativo a $95 \%$ e $\left({ }^{* *}\right)$ significativo a $90 \%$ de probabilidade, respectivamente, pelo teste $t$ de Student.

Org.: Domingues, I.A.S. (2010). 
- Balanço Hídrico Normal por anos ENOS

Quanto às variáveis do $\mathrm{BH}$ Normal (Tabela 27), verificou-se em Cambé: correlação moderada em anos de La Niña para a variável EXC e produtividade com coeficiente de correlação de $r=0,66$, confirmada a nível de significância de $10 \%$ com $t_{n-1}=1,761$. Ou seja, com $90 \%$ de confiabilidade, aumentando o excedente hídrico, durante esse episódio, há aumento de produtividade. No entanto, em anos de El Niño pode ocorrer redução de produtividade na cultura da cana-de-açúcar (ROSSIN, 2009).

- Balanço Hídrico Sequencial por anos ENOS

Para o BH Sequencial decendial (Tabela 27): anos de El Niño, para a variável DEF, verificou-se correlação moderada, com $r=-0,49$, confirmada a nível de significância de $10 \%$ com $t_{n-1}=1.686$ (o coeficiente de correlação mostra que quando há redução na deficiência hídrica há aumento de produtividade). Em anos de La Niña houve correlação moderada entre EXC e produtividade, com coeficiente de $r=0,66$ a nível de significância de $5 \%$ com $t_{n-1}=2,666$ em Cambé e em Mirador de $r=0,63$ a nível de $10 \%$ com $t n-1=1,602$.

Nos anos com fenômeno ENOS (Tabela 27), dos 25 anos por estádio fenológico constataram-se as seguintes correlações: em Cambé, anos de El Niño, para DEF nos estádios de estabelecimento/desenvolvimento, com correlação moderada de $r=-0,50$ a nível de significância de $5 \%$ com $t_{n-1}=1.745$. Em anos de La

Niña houve forte correlação para EXC nos estádios de estabelecimento/desenvolvimento e de maturação, com coeficiente de $r=0,80$ e $r=-$ 0,90 a nível de significância de $5 \%$ com $t_{n-1}=2,654$ e $t n-1=3,053$, respectivamente. Para a DEF houve forte correlação na maturação, com $r=0,84$ a nível de significância de $5 \%$ com $t_{n-1}=3,053$. 
- Balanço Hídrico de Cultura por anos ENOS

No BH de Cultura em Cambé (Tabela 28), o EXC e a produtividade apresentaram forte correlação em anos de La Niña nos estádios de estabelecimento, desenvolvimento e maturação. Para estes o coeficiente de correlação foi de $r=0,80$, $r=0,79$ e $r=-0,80$ a nível de significância de $5 \%$ com $t_{n-1}=2,658, t_{n-1}=2,576$ e $t_{n-}$ ${ }_{1}=2,663$, respectivamente. Para a DEF houve correlação moderada em anos de EL Niño no estabelecimento e maturação com $r=-0,57, r=-0,62$, significativo a $95 \%$ de probabilidade, com $t_{n-1}=2,097$ e $t_{n-1}=2,389$, enquanto em anos de La Niña a correlação foi forte nos três estádios fenológicos, com $r=-0,87, r=-0,77$ e $r=0,97$ a nível de significância de $t_{n-1}=3,521, t_{n-1}=2,413$ e $t_{n-1}=8,019$.

Em Mirador, para as variáveis EXC e DEF, houve correlação moderada para a primeira e forte para a segunda em anos de La Niña no estádio de desenvolvimento. O coeficiente de correlação foi de $r=-0,57$ e $r=-0,76$ com nível de significância de $90 \%$ e $95 \%$ de probabilidade com $t_{n-1}=1,539$ e $t_{n-1}=2,338$, respectivamente.

No BH de Cultura (Tabela 28) o EXC, em Cambé, apresentou forte correlação em anos de La Niña nos três estádios fenológicos, com $r=0,80, r=0,79$ e $r=-0,80$ a nível de significância de $5 \%$ com $t_{n-1}=2,658, t_{n-1}=2,576$ e $t_{n-1}=2,663$, respectivamente. Para a DEF houve correlação moderada em anos de EL Niño no estabelecimento e maturação, com $r=-0,57, r=-0,62$, significativo a $95 \%$ de probabilidade, com $t_{n-}$ ${ }_{1}=2,097$ e $t_{n-1}=2,389$, enquanto em anos de La Niña a correlação foi forte nos três estádios fenológicos, com $r=-0,87, r=-0,77$ e $r=0,97$ em níveis de significância de $t_{n-}$ ${ }_{1}=3,521, t_{n-1}=2,413$ e $t_{n-1}=8,019$. Em Mirador, para as variáveis EXC e DEF, houve correlação moderada para a primeira e forte para a segunda em anos de La Niña no estádio de desenvolvimento. O coeficiente de correlação foi de $r=-0,57$ e $r=-0,76$ com nível de significância de $90 \%$ e 95\% de probabilidade, com $t_{n-1}=1,539$ e $t_{n-}$ ${ }_{1}=2,338$, respectivamente. 
Tabela 28 - Correlação ( $r$ e e teste $t$ Student entre EXC e DEF (BH de Cultura) para o período de 25 anos por estádios fenológicos e em anos de ENOS por estádios fenológicos, série de anos de 1981/82 a 2005/06, municípios de Cambé e Mirador, PR.

\begin{tabular}{|c|c|c|c|c|c|c|}
\hline & & & & MBÉ & MIF & ADOR \\
\hline & & & $\mathbf{r}$ & $t_{n-1}$ & $r$ & $t_{n-1}$ \\
\hline 25 anos & & EXC & 0,20 & ns & 0,10 & ns \\
\hline & & DEF & $-0,33$ & $1,613\left({ }^{* \star}\right)$ & $-0,20$ & $\mathrm{~ns}$ \\
\hline & & Estab & $-0,10$ & $\mathrm{~ns}$ & 0,10 & ns \\
\hline & EXC & Desenv & 0,31 & $1,513\left({ }^{* \star}\right)$ & 0,00 & ns \\
\hline & & Matur & 0,10 & $\mathrm{~ns}$ & 0,10 & ns \\
\hline 25 anos & & Estab & 0,03 & ns & $-0,03$ & ns \\
\hline & DEF & Desenv & $-0,43$ & $2,353\left(^{*}\right)$ & $-0,17$ & ns \\
\hline & & Matur & $-0,10$ & ns & $-0,17$ & ns \\
\hline Anos ENOS & & & & & & \\
\hline & & Estab & $-0,23$ & ns & 0,11 & ns \\
\hline El Niño & & Desenv & 0,31 & ns & $-0,08$ & ns \\
\hline & & Matur & 0,24 & $\mathrm{~ns}$ & $-0,08$ & $\mathrm{~ns}$ \\
\hline & & Estab & 0,80 & $2,658\left(^{*}\right)$ & 0,61 & ns \\
\hline La Niña & EXC & Desenv & 0,79 & $2,576\left(^{*}\right)$ & $-0,57$ & ns \\
\hline & & Matur & $-0,80$ & $2,663\left(^{*}\right)$ & 0,03 & ns \\
\hline & & Estab & $-0,36$ & $\mathrm{~ns}$ & $-0,30$ & ns \\
\hline Neutro & & Desenv & 0,20 & ns & 0,20 & ns \\
\hline & & Matur & 0,22 & ns & 0,37 & ns \\
\hline & & Estab & 0,32 & $\mathrm{~ns}$ & $-0,20$ & $\mathrm{~ns}$ \\
\hline El Niño & & Desenv & $-0,57$ & $2,097\left(^{*}\right)$ & $-0,11$ & $\mathrm{~ns}$ \\
\hline & & Matur & $-0,62$ & $2,389\left(^{*}\right)$ & $-0,18$ & $\mathrm{~ns}$ \\
\hline & & Estab & $-0,87$ & $3,521\left(^{*}\right)$ & $-0,10$ & ns \\
\hline La Niña & DEF & Desenv & $-0,77$ & $2,413\left(^{*}\right)$ & $-0,76$ & $2,338\left(^{*}\right)$ \\
\hline & & Matur & 0,97 & $8,019\left(^{*}\right)$ & 0,03 & $\mathrm{~ns}$ \\
\hline & & Estab & 0,16 & $\mathrm{~ns}$ & 0,20 & $\mathrm{~ns}$ \\
\hline Neutro & & Desenv & $-0,37$ & $\mathrm{~ns}$ & $-0,05$ & $\mathrm{~ns}$ \\
\hline & & Matur & $-0,16$ & ns & $-0,11$ & ns \\
\hline
\end{tabular}

ns (não-significativo), $\left({ }^{*}\right)$ significativo a $95 \%$ e $\left({ }^{* *}\right)$ significativo a $90 \%$ de probabilidade, respectivamente, pelo teste $t$ de Student.

Org.: Souza, I.A. (2010).

Quanto à temperatura do $\mathrm{BH}$ de Cultura por anos ENOS (Tabela 29): em Cambé verificou-se forte correlação em anos de La Niña nos estádios de desenvolvimento e maturação e correlação moderada no estabelecimento e desenvolvimento em anos Neutros. Os coeficientes de correlação para esses estádios foram de $r=0,81$ com $t_{n-1}=2,788, r=0,91$ com $t_{n-1}=4,441, r=0,44$ com $t_{n-}$ $1=1,476$ e $r=-0,69$ e $t_{n-1} 1=2,861$, com nível de significância de 95\% de probabilidade, com exceção do estádio de estabelecimento, que foi de 90\%. Em Mirador houve forte correlação em anos de La Niña no estádio de desenvolvimento, com $r=-0,86$ e $t_{n-1}=5,006$ a nível de significância de 5\%. 
Tabela 29 - Correlação $(r)$ e teste $t$ Student entre temperatura e produtividade, para estádios fenológicos (BH Cultura) do período de 25 anos e por anos de ENOS, série de anos de 1981/82 a 2005/06 nos municípios de Cambé e Mirador, PR.

TEMPERATURA POR ESTADIOS FENOLOGICOS

\begin{tabular}{|c|c|c|c|c|c|c|}
\hline & & & \multicolumn{2}{|c|}{ Cambé } & \multicolumn{2}{|c|}{ Mirador } \\
\hline \multirow{4}{*}{25 Anos } & & & $r$ & $t_{n-1}$ & $r$ & \\
\hline & & Estab & 0,19 & $\begin{array}{l}n-1 \\
n S\end{array}$ & 0,44 & $2,368\left(^{*}\right)$ \\
\hline & & Desenv & $-0,18$ & ns & $-0,11$ & $\mathrm{~ns}$ \\
\hline & & Matur & $-0,15$ & ns & 0,03 & ns \\
\hline \multirow{9}{*}{ ENOS } & \multirow{3}{*}{ El Niño } & Estab & 0,31 & ns & 0,59 & $2,207\left(^{*}\right)$ \\
\hline & & $\begin{array}{l}\text { Desenv } \\
\end{array}$ & 0,29 & ns & 0,00 & ns \\
\hline & & Matur & $-0,14$ & ns & 0,18 & ns \\
\hline & \multirow{3}{*}{ La Niña } & Estab & $-0,58$ & ns & 0,17 & ns \\
\hline & & Desenv & 0,81 & $2,788\left(^{*}\right)$ & $-0,86$ & $5,006\left(^{*}\right)$ \\
\hline & & Matur & 0,91 & $\left.4,4411^{*}\right)$ & $-0,24$ & ns \\
\hline & \multirow{3}{*}{ Neutro } & Estab & 0,44 & $1,476\left(^{* \star}\right)$ & 0,40 & ns \\
\hline & & Desenv & $-0,69$ & $2,851\left(^{*}\right)$ & $-0,12$ & ns \\
\hline & & Matur & $-0,13$ & $\mathrm{~ns}$ & 0,24 & ns \\
\hline
\end{tabular}

ns (não-significativo), $\left({ }^{*}\right)$ significativo a $95 \%$ e $\left({ }^{\star *}\right)$ significativo a $90 \%$ de probabilidade, respectivamente, pelo teste $t$ de Student.

Org.: Domingues, I.A.S. (2010).

Em face desses resultados de correlação tem-se que: para as variáveis hídricas e produtividade, é comum ocorrer aumento de produtividade se houver aumento de chuva ou EXC nos estádios de estabelecimento e desenvolvimento da cultura e redução de produtividade em caso de DEF. Se o estádio for de maturação, há o inverso, ou seja, ocorre aumento de produtividade quando houver aumento de DEF. Tais situações ocorrem com maior frequência em anos de La Niña. Esse mesmo procedimento é comum ocorrer com a temperatura.

Situações semelhantes foram encontradas para outras culturas, como, por exemplo, o milho no Rio Grande do Sul, que apresentou correlações significativas entre variável hídrica e produtividade para a maioria dos períodos estudados (BERLATO et. al. (2005). Para essa mesma cultura, Ferreira (2006) identificou correlações significativas (coeficiente de correlação moderado com nível de significância de 1\%) para os trimestres de DJF e JFM, FMA para o estado do Paraná e para os estados do Rio Grande do Sul, Santa Catarina, São Paulo apenas dois trimestres, DJF e JFM, dentre os sete estados pesquisados. Alberto (2005), pesquisando as culturas de soja, milho e trigo na região de Santa Maria, RS, verificou que anos Neutros constituem anos de maior risco para essas culturas. Cunha et al. (1999) verificaram que para a cultura do trigo nos estados da região Sul 
do Brasil houve correlação significativa em anos de El Niño, causando impactos negativos, e em anos de La Niña com impactos positivos.

\subsection{7 - Tipos de solos e a produtividade da cultura da cana-de-açúcar}

Embora a variável solo não tenha sido incluída diretamente nesta pesquisa, ela foi considerada na escolha das áreas estudadas, uma vez que ocorrem dois tipos de solos: um com textura argilosa, derivado das rochas vulcânicas, Formação Serra Geral, e o outro com textura arenosa, oriundo da Formação Caiuá.

A média de chuva na área sobre solo argiloso é superior à área de solo arenoso em $119,0 \mathrm{~mm}$, embora a média da temperatura seja de $1,2^{\circ} \mathrm{C}$ mais reduzida.

Dessa forma, uma das considerações a respeito de as correlações entre variáveis hídricas e produtividade serem mais significativas em Cambé, além de apresentar produtividade mais elevada que em Mirador, poderia ser em parte explicada pelas propriedades químicas e físicas dos solos, uma vez que os solos considerados apresentam composição mineralógica diferenciadas. Segundo Buso (2006), os solos de áreas com alta produtividade de cana-de-açúcar normalmente apresentam grande capacidade de armazenamento de água. Além disso, solos onde

o sistema radicial atinge profundidade em torno de $1,10 \mathrm{~m}$ ajudam a planta a suportar período seco em até 22 dias, enquanto que em solos onde as raízes se concentram nos primeiros $40 \mathrm{~cm}$ a cultura suporta até oito dias de estresse hídrico (ROSELEN, 1994).

A respeito desses tipos de solos, pesquisas mostram, por exemplo, que o Latossolo Vermelho eutroférrico (LVef) de Cambé apresentou maior retenção de água em todas as tensões e a mesma capacidade de água disponível (CAD) em relação ao Latossolo Vermelho distrófico (LVd) de Mirador (BEUTLER et al., 2002), embora, sob cultivo de cana-de-açúcar, os Latossolos apresentem variabilidade diferenciada para os atributos granulométricos (SOUZA, et al., 2004). Pode comprometer a macroestrutura, a densidade do solo, a condutividade hidráulica e o carbono orgânico das camadas subsuperficiais do solo (SILVA, et al., 1998). Em 
solos com textura arenosa e média, diferentes cultivares de cana-de-açúcar apresentaram comportamentos de produtividade variados em consequencia das condições hídricas entre estes (MAULE et al., 2001). 


\section{5 - CONCLUSÃo}

No Paraná, a cana-de-açúcar é cultivada, em sua grande maioria, nas mesorregiões Norte Central, Norte Pioneiro, Noroeste e Centro Ocidental, perfazendo $41 \%$ dos 399 municípios que compõem esse estado e que estão localizados nas latitudes menores que $24^{\circ}$. Estas apresentaram as maiores produtividades, acima de 77 ton/ha.

$\mathrm{Na}$ caracterização geográfica da variação espaço-temporal, essa cultura apresentou as melhores produtividades nos anos de 1998 nas mesorregiões Norte Central, Noroeste e Norte Pioneiro, seguidas da Centro Ocidental; em 2002 na Norte Pioneiro, seguida da Norte Central, Noroeste e Centro Ocidental; e em 2006 na Centro Ocidental, seguida da Norte Pioneiro, Norte Central e Noroeste.

Dentro dessas mesorregiões, a área de recorte para o estudo da variabilidade climática foram os municípios de Cambé e de Mirador, por apresentarem características pedológicas distintas, solos argilosos e arenosos, respectivamente.

A série de dados de produtividade após a retirada da tendência tecnológica teve redução na média de 7,7 ton/ha em Cambé e de 3,6 ton/ha em Mirador. As maiores produtividades ocorreram em 1982, 1996 e 2003 e as menores em 1984, 1989 e 2005 em Cambé, e em Mirador nos anos de 1989, 1995 e 1998 para as maiores e em 1984, 2000 e 2003 para as menores produtividades.

Em relação aos dados pluviométricos médios, estes foram maiores em Cambé, com valores de $119 \mathrm{~mm}$, e menores para os térmicos, com $1,2^{\circ} \mathrm{C}$, que em Mirador. As chuvas com intensidade acima de $50 \mathrm{~mm}$ foram também mais frequentes em Cambé. Quanto às temperaturas acima de $16^{\circ} \mathrm{C}$, estas foram mais frequentes em Mirador.

A análise de correlação entre os dados climáticos e de produtividade foi considerada significativa: Cambé - para chuva e produtividade no período de 25 anos e em anos de La Niña; para BH Normal em anos de La Niña; BH Sequencial para DEF dos 25 anos, em anos de El Niño no estádio estabelecimento/desenvolvimento e em La Niña no estádio de maturação; EXC em anos de La Niña no estádio de estabelecimento/desenvolvimento e em anos Neutros no estádio de maturação; BH de Cultura para EXC e DEF dos 25 anos no 
desenvolvimento, em anos de La Niña nos estádios de estabelecimento e desenvolvimento e DEF em anos de El Niño no desenvolvimento e maturação; para temperatura do período de 25 anos em anos de La Niña e na maioria dos estádios para eventos ENOS; em Mirador - para chuva e produtividade no período de 25 anos em anos de La Niña; no BH Sequencial em anos de La Niña para EXC e no BH de Cultura também em anos de La Niña para EXC e DEF no estádio de desenvolvimento; temperatura por estádios fenológicos para período de 25 anos e para anos de El Niño, ambos no estádio de estabelecimento; e em anos La Niña no estágio de desenvolvimento.

As condições hídricas observadas nos extratos do BH Sequencial revelaram que houve queda de produtividade de até $70 \%$ da média para situação de EXC menor que a média e DEF maior, principalmente no estádio de desenvolvimento. No $\mathrm{BH}$ de Cultura essa condição, mostrada nos extratos, ocorreu principalmente quando houve EXC reduzido e prolongado no estádio de desenvolvimento, bem como DEF no desenvolvimento, intercalada com EXC.

Quanto aos episódios ENOS, percebeu-se que anos com chuva acima da média (El Niño) e anos com chuva na média do período (Neutros) apresentaram correlação com menor grau de significância com a produtividade da cana-de-açúcar que em anos com chuva abaixo da média (La Niña).

Diante dessas condições climáticas, conclui-se que, para a área de Cambé, as variáveis hídricas e térmicas (chuva, EXC e DEF, temperatura) apresentaram maior correlação com a produtividade no $\mathrm{BH}$ de Cultura para a série temporal estudada e para os anos ENOS. Já na área de Mirador há correlação significativa para EXC do BH Sequencial Decendial para o período de 25 anos, para DEF do BH Cultura e em anos de La Niña no estádio de desenvolvimento. A variável térmica apresentou correlação significativa para $\mathrm{BH}$ de Cultura nos estádios de desenvolvimento vegetativo para o período de 25 anos em anos de El Niño e de La Niña. 


\section{6 - REFERÊNCIAS BIBLIOGRÁFICAS}

ALCOPAR, Associação de Produtores de bioenergia do estado do Paraná. Disponível em: <http/www.alcopar.com.br>. Acesso em abr. 2007.

ALFONSI, R.R. Agrometeorologia e sua importância para uma agricultura racional e sustentável. In: SANT'ANNA NETO; ZAVATINI, J. A. (Org.). Variabilidade e mudanças climáticas: Implicações ambientais e socioeconômicas. Maringá: Eduem, 2000. p. 213-223.

ALFONSI, R. R. et al. Condições climáticas para a cana-de-açúcar. In: PARANHOS, S.B. (Coord). Cana-de-açúcar: cultivo e utilização. Campinas, Fundação Cargill, 1987. v. 1, p. 42-55.

ALMEIDA, F. F. M. de. - Aspectos gerais da geologia da Bacia do Alto Paraná. In: SIMPÓSIO SOBRE A GEOTECNIA DA BACIA DO ALTO PARANÁ, São Paulo, 1983. Anais... São Paulo: ABMS/ABGE/CBMR, 1983. p. 9-16.

ALMEIDA, I.R. de. Variabilidade pluviométrica interanual e produção de soja no estado do Paraná. 2000. Dissertação (Mestrado em Geografia). Faculdade de Ciências e Tecnologia, Universidade Estadual Paulista, Presidente Prudente, 2000.

ALVAREZ, I.A; CASTRO, P.R.C.; NOGUEIRA, M.C.S. Crescimento de raízes de cana crua e queimada em dois ciclos. Scientia Agricola, Piracicaba, v. 57, n. 4, p. 653-659, 2000.

AMBIENTEBRASIL. Aptidão do solo paranaense. Disponível em: $<$ http://www.ambientebrasil.com.brl>. Acesso em: Abr. 2008.

ANDRADE, L.A. de B. Cultura da cana-de-açúcar. In: CARDOSO, M. das G. (Ed.). Produção de aguardente de cana-de-açúcar. 3 ed. Lavras: UFLA, 2006. p. 25-67.

ANDRADE, L.A. de B. Cultura da cana-de-açúcar. In: CARDOSO, M. das G. (Ed.). Produção de aguardente de cana-de-açúcar. 2 ed. rev. e amp. Lavras: Ufla, 2006. p.25-67.

AYOADE, J. O. Introdução à climatologia para os trópicos. 3 ed. Rio de Janeiro: Bertrand do Brasil, 1996. 332 p.

BACCHI, O.O.S. Ecofisiologia da cana-de-açúcar. Piracicaba: IAA/Planalsucar, 1985. 20p.

BACCHI, O.O.S.; FERRARI, S.E.; ROLIM, V.C. Acompanhamento do estado de maturação da cana-de-açúcar submetida à geada e deterioração após o fenômeno. Araras: IAA / PLANALSUCAR. Consul, 1980. s.p., (Mimeografado).

BARBIERI, V.; VILLA NOVA, N. A. Climatologia e a cana-de-açúcar. Araras: PLANALSUCAR. Coordenadoria Regional Sul. COSUL, 1977. p. 1-22.

BARBOSA, E.A. Avaliação fitotécnica de cinco variedades de cana-de-açúcar para o município de Salinas, MG. 2005. 72f. Dissertação (Mestrado em Agronomia). Universidade Estadual do Sudeste da Bahia. 2005.

BERLATO, M. A.; CORDEIRO, A. P. A. Variabilidade climática e agricultura do Rio Grande do Sul. In: Federação dos Clubes de Integração e Troca de Experiência FEDERACITEa. (Org.). As Estiagens e as Perdas na Agricultura: Fenômeno Natural ou Imprevidência? Porto Alegre: Ideograf Editora Gráfica, 2005, v. 1, p. 43-59. 
BERLATO, M.A.; FARENZENA, H.; FONTANA, D.C. Associação entre El Niño Oscilação Sul e a produtividade do milho no estado do Rio Grande do Sul. Pesq. agropec. bras. v. 40, n. 5, p. 423-432, 2005

BERLATO, A.M.; FONTANA, D.C. El Niño e La Niña: impactos no clima, na vegetação e na agricultura do Rio Grande do Sul; aplicações de previsões climáticas na agricultura. Porto Alegre: UFRGS, 2003.110 p.

BEUTLER, A. N. et al. Retenção de água em dois tipos de latossolos sob diferentes usos. Rev. Bras. Ci. Solo, 26:829-834, 2002.

BLACKBURN, F. Sugarcane. Singapura: Longman Group Limited, 1984. 414 p.

BORGES, I.D. et al. Distribuição do sistema radicular da cana-de-açúcar submetida à irrigação complementar. In: SIMPÓSIO BRASILEIRO SOBRE ECOFISIOLOGIA, MATURAÇÃO E MATURADORES EM CANA-DE-AÇÚCAR, 13-15 maio 2008, Botucatu, SP. Anais... Botucatu, SP: Universidade Estadual Paulista (UNESP)/Faculdade de Ciências Agronômicas (FCA), 2008. p. 95-99.

BORSATO, V.A.; SANT'ANNA NETO, J.L. Caracterização e análise da produtividade do trigo relacionada à pluviosidade na bacia hidrográfica do rio Pirapó. Boletim de Geografia, Maringá, ano 20, n. 1, p.33-57. 2002.

BRANDÃO, A. P; PINTO, P. A. Alterações climáticas e a agricultura portuguesa: impactos e medidas de adaptação. Disponível em: <http://www.ordemengenheiros.pt/LinkClick.aspx?link92-Paginas75-c.pdf> Acesso em: jun. 2008.

BRASIL. Ministério da Agricultura, Pecuária e Abastecimento. Secretaria de Produção e Comercialização. Estatísticas: agronegócio brasileiro. Disponível em: $<$ http//www. Agricultura.gov.br>. Acesso em: maio 2008.

BRAY, S.C. A cultura da cana-de-açúcar no vale do Paranapanema: um estudo de geografia agrária. 1980. 304f. Tese (Doutorado) - Universidade de São Paulo, São Paulo, 1980.

BRINHOLI, O. Resistência ao frio de diferentes variedades de cana-de-açúcar (Saccharum spp). Piracicaba, ESALQ/USP, 1978. 113 p. Tese (Doutorado em Agronomia) - Escola Superior de Agronomia Luiz de Queiroz, Piracicaba, 1978.

BUSO, P. H. de M. Estudo do sistema radicial de cana-de-açúcar no plantio em gema e tolete. Dissertação (Mestrado em Produção Vegetal) - Universidade Federal do Paraná, Curitiba, 2006.

CAMARGO, P. N. Fisiologia da cana-de-açúcar. Piracicaba: ESALQ, 1968. 38p.

CAMARGO, A.P; PEREIRA, A.R. Prescrição de rega por modelo climatológico. Campinas: Fundação Cargill, 1990. 27p.

CARMONA, L. de Campos; BERLATO, M.A. El Niño e La Niña e o rendimento do arroz irrigado no estado do Rio Grande do Sul. Revista Brasileira de Agrometeorologia, Santa Maria, v. 10, n. 1, p. 147-152. 2002.

CARAMORI, P. H., PUGSLEY, L., CAVIGLIONE, J. H., OLIVEIRA, D. Cartas climáticas de Londrina - Edição 2003, 2003.

CARAMORI, P. H.; et al. Análise da ocorrência de geadas no estado do Paraná com base na temperatura de superfície obtida dos dados AVHRR/NOAA. In: SIMPÓSIO 
BRASILEIRO DE SENSORIAMENTO REMOTO, 21-26 abr. 2007, Florianópolis, SC. Anais... INPE, 2007. p. 5623-5629.

CASAGRANDE, A. A. Tópicos de morfologia e fisiologia da cana-de-açúcar. Jaboticabal: FUNEP, 1991. 157p.

CASTRO, P. R. C.; CHRISTOFFOLETI, P.J. Fisiologia da cana-de-açúcar. In: Arthur F. M. (Org.). Cigarrinhas da cana-de-açúcar: controle biológico. Maceió: INSECTA, 2005. v. 1, p. 3-45.

CASTRO, P. R. C.; KLUGE, R. A. (Ed.). Ecofisiologia de culturas extrativas. Canade-açúcar, seringueira, coqueiro, dendezeiro e oliveira. Cosmópolis: Stoller do Brasil, 2001. 138p.

CASTRO, P.R.C. Maturadores químicos em cana-de-açúcar. In: SEMANA DA CANA-DE-AÇÚCAR EM PIRACICABA, Secapi, 4, 1999. Piracicaba. Anais... Piracicaba: Saccharum, 1999. p. 12-16.

CASTRO,P.R.C. Ecofisiologia da produção agrícola. Piracicaba: Potafos, 1987. 249p.

CAVIGLIONE, J.H.; et al. Cartas climáticas do Paraná. Londrina: Instituto Agronômico do Paraná, 2000. 1CD.

CHRISTOFOLETTI, A.L.H. Procedimentos de análise utilizados no estudo da precipitação. Geociências, São Paulo, v. 11, n. 1, p.75-98. 1992.

CHRISTOFFOLETI, P. J. Aspectos fisiológicos da brotação, perfilhamento e florescimento da cana-de-açúcar. Piracicaba: ESALQ, 1986. 80 p.

COPERSUCAR. Agrícola Informa. Agricultura de precisão na cultura de cana-deaçúcar. Boletim n. 91, Piracicaba, 1998.

CONAB - Companhia Nacional de Abastecimento. Acompanhamento da safra brasileira cana-de-açúcar, safra 2007/2008. Terceiro Levantamento. Brasília, 2007. Disponível em: <http://www.conab.gov.br/conabweb/download/safra/3lev-cana.pdf>. Acesso em: fev. 2008.

CONTI, J. B. Considerações sobre mudanças climáticas globais. In: SANT'ANNA NETO; ZAVATINI, J. A. (Org.). Variabilidade e mudanças climáticas: implicações ambientais e socioeconômicas. Maringá: Eduem, 2000, p. 17-28.

CUENCA, M.A.G.; NAZARIO, C.C. Caracterização agrossocioeconômica da atividade canavieira no Brasil e distribuição espacial da produção mundial entre 1961 e 2003. Aracaju: Embrapa Tabuleiros Costeiros. 2005.

CUNHA, G.R. da; DAMALGO, G.A.; ESTEFANEL, V. ENSO influences on wheat crop in Brazil. Revista Brasileira de Agrometeorologia, Santa Maria, v. 7, n. 1, p. 127138, 1999.

CRESPO, A. A. Estatística fácil. 18 ed. São Paulo: Saraiva, 2002. 224p.

CUNHA, G.R.; DALMAGO, G.A.; ESTEFANEL, V. ENSO Influences on wheat crop in Brazil. Revista Brasileira de Agrometeorologia, v. 7, p.127-138, 1999.

DEFFUNE, G.; GALVANI, E. Determinação do balanço hídrico de Maringá-PR: 1976-1992. Boletim de Geografia, Maringá, ano 12, n. 1, p. 28-71, jun. 1994.

DOORENBOS, J., PRUITT, W. O. Guidelines for predicting crop water requirements. Rome: FAO, 1975. 179 p. Paper, 24. 
DOORENBOS, J.; KASSAM, A.H. Efeito da água no rendimento das culturas. Estudos FAO, Irrigação e Drenagem 33. Tradução Gheyi, H.R. et al., UFPB, Campina Grande. FAO.1994. 306p.

EMBRAPA (Empresa Brasileira de Pesquisa Agropecuária) - IAPAR (Fundação Instituto Agronômico do Paraná). Levantamento de reconhecimento dos solos do estado do Paraná. Convênio SUDESUL - EMBRAPA. Governo do Estado do Paraná/IAPAR. Tomo I e II. Mapa Escala 1:600.000. Londrina (PR), 1984. 791p.

FERNANDES, A.C. Refratômetro de campo. Boletim Técnico Copersucar, v. 19, p. 5-12, 1982.

FERNANDES, O. W. B. Avaliação de variedades de cana-de-açúcar para a produção de cachaça artesanal e a interferência dos resultados no comportamento do produtor na região de Salinas-MG. 2005. 83f. Dissertação (Mestrado) - UFRRJ, Seropédica. 2005.

FERREIRA, D.B. Relações entre a variabilidade da precipitação e a produtividade agrícola de soja e milho nas regiões Sul e Sudeste do Brasil. 123f. Dissertação (Mestrado em Meteorologia) - São José dos Campos: INPE. 2005.

FIGUEIREDO, P.; LANDELL, M. G. A.; CAMPANA, M. P. Cana-de-açúcar. 6 ed. Campinas: IAC, 1995. Boletim 200. 1CD.

FUNDAÇÃO IBGE. Contagem da população. Rio de Janeiro, IBGE, Diretoria de Pesquisas - Departamento de População e Indicadores Sociais. IBGE, 1996. 1CD.

FUNDAÇÃO SOS Mata Atlântica/INPE. Atlas dos remanescentes florestais da Mata Atlântica e ecossistemas associados no período de 1995-2000. São Paulo, SOS Mata Atlântica. 2001. Disponível em: $<$ http://www.sosma.org.br/index.php?section=atlas\&action=atlas $>$. Acesso em: mai. 2008.

GALVANI, E.; PEREIRA, A.R.; KLOSOSWKI, E.S. Relações entre o Índice de Oscilação Sul (IOS) e o total mensal de chuva em Maringá-PR. Acta Scientiarum, 20(4): 531-535, 1998.

GALVANI, E. EI Niño-Oscilação Sul (ENOS) e seus efeitos nas variações das chuvas na cidade de Piracicaba, SP. 1995. 80f. Dissertação (Mestrado em Agrometeorologia) - ESALQ, Piracicaba. 1995.

GASPARETTO, N.V. L., SOUZA, M. L de. Contexto geológico geotécnico da formação Caiuá do Terceiro Planalto Paranaense-PR. Anais... ENCONTRO GEOTÉCNICO DO TERCEIRO PLANALTO PARANAENSE. Maringá, PR, p. 53-65, 2003. 1 CD.

GOMIDE, J.A.. Fisiologia do crescimento livre de plantas forrageiras. In: PEIXOTO, MOURA, J.C. de; FARIA, V.P. de (Eds.). Pastagens: fundamentos da exploração racional. Piracicaba: FEALQ,1994. p. 1-14.

GRODZKI, L. et al. Risco de ocorrência de geada no estado do Paraná. Revista Brasileira de Agrometeorologia, Santa Maria, v. 4, n. 1, p. 93-99, 1996.

GUERRA, J.R. e CARAMORI, P.H. Influência dos fenômenos El Niño e La Niña sobre a produtividade da cultura do trigo no estado do Paraná. In: CONGRESSO BRASILEIRO DE AGROMETEOROLOGIA, 13, 2003. Anais... Santa Maria: Sociedade Brasileira de Agrometeorologia, 2003, vol. 1, p. 579-580. 
INSTITUTO BRASILEIRO DE GEOGRAFIA E ESTATÍSTICA - IBGE. Produção agrícola municipal 2006 e 2007. Disponível em: <http//www.ibge.gov.br>. Acesso em: fev. 2007.

INMAN-BAMBER, N. G.; SMITH, D. M. Water relations in sugarcane and response to water deficits. Field Crops Research, Amsterdam, v. 92, p. 185-202, 2005.

INMAN-BAMBER, N. G. Sugarcane water stress criteria for irrigation and drying off. Field Crops Research. v. 89, p.107-122, 2004. in: Elsevier Science, Amsterdam, 2004.

INMAN-BAMBER, N. G. Temperature and seasonal effects on canopy development and light interception of sugarcane. Field Crops Research, Amsterdam, v. 36, p. 41$51,1994$.

INSTITUTO PARANAENSE DE DESENVOLVIMENTO ECONÔMICO E SOCIAL IPARDES. Mesorregiões geográficas paranaenses. 2004. Disponível em: $<$ http://www.ipardes.gov.br/webisis.docs/leituras reg sumario executivo.pdf >. Acesso em: 08 Out. 2007.

KATZ, E. Influência climática na produção de cana-de-açúcar no núcleo canavieiro de Jaú (SP). 1995. Dissertação (Mestrado) - IGCE - UNESP, Rio Claro, 1995.

KIM, I.S.; DUQUIA C.G. \& CALVETTI, L. Regionalização do estado do Paraná com a utilização dos campos de precipitação, temperatura mínima e máxima. In: CONGRESSO BRASILEIRO DE METEOROLOGIA, Rio de Janeiro. 2000.

KOFLER, N. F.; DONZELI, P. L. Avaliação dos solos brasileiros para a cultura da cana-de-açúcar. In: PARANHOS, S. B. (Coord.). Cana-de-açúcar: cultivo e utilização. Campinas: Fundação Cargil, 1987, v. 2, p. 19-41.

MAACK, R. Geografia física do estado do Paraná. Curitiba: Imprensa Oficial do Paraná, 2002. 438p.

MACHADO, R.S. et al. Fotossíntese e conteúdo foliar de carboidratos em cana-deaçúcar. In: SIMPÓSIO BRASILEIRO SOBRE ECOFISIOLOGIA, MATURAÇÃO E MATURADORES EM CANA-DE-AÇÚCAR, 13-15 maio, 2008. Anais... Botucatu: UNESP/FCA, 2008, p. 1-5.

MACHADO, E. C. Fisiologia de produção de cana-de-açúcar. In: PARANHOS, S.B. (Coord). Cana-de-açúcar: cultivo e utilização. Campinas, Fundação Cargil, 1987. v. 1, cap. 1, p. 56-87.

MACHADO, E.C. Um modelo matemático-fisiológico para simular o acúmulo de matéria seca na cultura de cana-de-açúcar (Saccharum spp.). Campinas, 1981. 115f. Dissertação (Mestrado) - Instituto de Biologia/UNICAMP. 1981.

MAGALHÃES, A. C. N. Ecofisiologia da cana-de-açúcar: aspectos do metabolismo do carbono da planta. In: Castro, P. R. C.; Ferreira, S. O.; Yamada, T. (Coord.). Ecofisiologia da produção. Piracicaba: Associação Brasileira para pesquisa do Potássio e do Fosfato, 1987. p. 113-118.

MARTINELLI, M. Curso de cartografia temática. São Paulo: Contexto, 1991. 180p.

MATSUOKA, S.; GARCIA A. A. F.; ARIZONO, H. Melhoramento da cana-de-açúcar. In: BOREN, A. (Ed.). Melhoramento de espécies cultivadas. 2 ed., Viçosa: UFV, 1999, p. 205-251. 
MATSUOKA, S. Botânica da cana-de-açúcar. In: MATSUOKA, S. Botânica e ecofisiologia da cana-de-açúcar. Araras: UFSCar, 1996. p.1-9.

MAULE, F.F.; MAZZA, J.A.; MARTHA, J.B.Jr. Produtividade agrícola de cultivares de cana-de-açúcar em diferentes solos e épocas de colheita. Scientia Agricola, v. 58, n. 2, p. 295-301, abr./jun. 2001.

MELO, M. S.; MENEGUZZO, I. S. Patrimônio natural dos Campos Gerais do Paraná. In: DITZEL, C. H. M.; LÖWEN SAHR, C. L. Espaço e Cultura: Ponta Grossa e os Campos Gerais. Ponta Grossa: UEPG, 2001. p. 415-428.

MINEROPAR - MINERAIS DO PARANÁ S/A. Atlas geológico do estado do Paraná. Governo do Estado do Paraná. Curitiba, PR, 2001. 1 CD.

MOLION, L.C.B. Aquecimento global: natural ou antropogênico? In CONGRESSO BRASILEIRO DE AGROMETEOROLOGIA,15, 2007, Aracaju. Anais...Aracaju: Sociedade Brasileira de Agrometeorologia, 2007. 1 CD-ROM.

MOLION, L.C.B. ENOS e o clima no Brasil. In: Ciência Hoje. Rio de Janeiro, SBPC, v. 10, n. 58, p. 24-29, 1989.

MOTA, F.S. da. Meteorologia agrícola. São Paulo: Nobel. 1979, p. 221-228.

MONTEIRO, A.L.G.; MORAES, A. Fisiologia e morfologia de plantas forrageiras In: MONTEIRO, A.L.G. et al. (Eds.). Forragicultura no Paraná. Londrina: CPAF,1996. p. 75-92.

MONTEIRO, C.A. de F. Sobre a análise geográfica de sequência de cartas de tempo: (pequeno ensaio metodológico sobre o estudo do clima no escopo da Geografia). Rev. Geog., Rio de Janeiro, v. 58, n. 1, p. 169-179, 1963.

NAGAROLLI, Mozart. Evolução climática do estado do Paraná: 1970-1999. 2007. 129 f. Dissertação (Mestrado em Geografia) - Universidade Federal do Paraná, Curitiba, 2007.

NAKASHIMA, P., NÓBREGA, M.T. Solos do Terceiro Planalto do Paraná - Brasil. In: ENCONTRO GEOTÉCNICO DO TERCEIRO PLANALTO PARANAENSE, 2003, Maringá, PR. Anais... Maringá, PR: UEM, 2003. pg. 66-85. 1CD.

NASCIMENTO JÚNIOR, D. do. Ecossistema de pastagem cultivadas. In: SIMPÓSIO SOBRE MANEJO DA PASTAGEM, 1998, Piracicaba, SP. Anais... Piracicaba, SP: FEALQ, 1998. p. 271-296.

NERY, J. MARTINS, M. L. O. F.; SAN'TANA NETO, J. L. Variabilidade da precipitação no Brasil meridional. Acta Scientiarum, Maringá, v. 24, n. 6, p. 16871695, 2002.

NERY, J. Aplicação do coeficiente de variação na precipitação pluviométrica no estado do Paraná. Revista UNIMAR 19(4):1125-1131, 1997.

NIMER, E. Climatologia do Brasil. Rio de Janeiro: IBGE, 1979. 422 p.

NOAA. ENSO: Cold and warm episodes by season. Disponível em: http://www.cpc.noaa.gov/products/analysis monitoring/insostuff/ensoyears.shtml. Acessado em: 05 mar 2010.

NOBREGA, M. T., CUNHA, J. E. O solo: caminho, abrigo e pão. In: VILLALOBOS, J. G. (Org.). Ambiente, geografia e natureza. Maringá: UEM, 2000. 
NUNES JUNIOR, D. Variedades de cana-de-açúcar In: PARANHOS, S.B. (Coord.). Cana-de-açúcar. Cultivo e utilização. Campinas: Fundação Cargil, v. 2, 1987, p. 187259.

OLIVEIRA ASSIS, P. C. et at. Resposta dos parâmetros tecnológicos da cana-deaçúcar a diferentes lâminas de irrigação e adubação. Revista de Biologia e Ciências da Terra, Pernambuco, v. 4 n. 2, $2^{\circ}$ semestre/2004. Disponível em: <http://eduep.uepb.edu.br/rbct/sumarios/pdf/tecnocana.pdf>. Acesso em: mar. 2008.

OLIVEIRA, M. W. et al. Análise quantitativa do crescimento da variedade de canade-açúcar RB 72454. In: ENCONTRO DE BOTÂNICOS DE MG, BA e ES. ENCONTRO DE BOTÂNICOS DE MG, BA E ES. 23. Resumos... UFV/SBB, 2001, v.1, p.89-89.

OLIVEIRA, R.A. de. Análise de crescimento da cana-de-açúcar, na região noroeste do Paraná. 2004, 55f. Dissertação (Mestrado em Agronomia, Produção Vegetal) Universidade Federal do Paraná, Curitiba, 2004.

OMETTO, J.C. Frequência de irrigação em cana-de-açúcar. Piracicaba: FEALQ, 1988. $77 \mathrm{p}$.

OMETTO, J.C. Bioclimatologia vegetal. São Paulo: Agronômica Ceres Ltda., 1981. $440 \mathrm{p}$.

PADILHA JUNIOR, J.B. O impacto da reserva legal florestal sobre a agropecuária paranaense, em um ambiente de risco. 2004. Tese - Universidade Federal do Paraná, Curitiba, 2004.

PARANÁ - Minerais do Paraná S/A. Sedimentação e magmatísmo mesozoico. Disponível em: <http/www.mineropar.pr.gov.br/modules/conteudo/conteúdo>. Acesso em: Out. 2007.

PARANHOS, S.B. Zoneamento agroclimático para o Brasil. In: PARANHOS, S.B. (Coord). Cana-de-açúcar. Cultivo e utilização. Campinas: Fundação Cargill, 1987. 856p.

PEREIRA, R.P.; ANGELOCCI, L.R.; SENTELHAS, P.C. Agrometeorologia fundamentos e aplicações práticas. Guaíba: Agropecuária, 2002. 478p.

PETERS, R. L. O efeito da mudança climática global sobre as comunidades naturais. In: Wilson, E. O. (Ed). Biodiversidade. Rio de Janeiro: Nova Fronteira, p. 576-589, 1997.

PINTO, H. Set al. Variabilidade climática. 2003. Disponível em: $<$ http://www.cpa.unicamp.br/prodcc/trabalhos-em-anais-de-eventos/tema12.pdf >.

Acesso em: jun. 2008.

PLANALSUCAR. Cultura da cana-de-açúcar. Manual de orientação. Piracicaba, 1986. $56 \mathrm{p}$.

PODESTÁ, G.P.; MESSINA, C.D.; GRONDONA, M.; MAGRIN, G.O. Association between grain crop yields in central-eastern Argentina and El Niño-south oscillation. Journal of Applied Meteorology, v. 38, p. 1488-1498, 1999.

PRELA, A. Influência dos fenômenos El Niño e La Niña na produtividade do trigo no estado do Paraná. 2004, 65f. Tese (Doutorado em Agronomia). Escola Superior de Agricultura Luiz de Queiroz, Piracicaba, SP, 2004. 
REICHARDT, K., TIMM, L.C. Solo, Planta e atmosfera. Conceitos, Processos e Aplicações. Barueri: Manole, SP, 2004. 478p.

REICHARDT, K. Dinâmica da matéria e da energia em ecossistemas. Piracicaba: USP/ESALQ, Depto. Física e Meteorologia, 1996. 513p.

RODRIGUES, J.D. Fisiologia da cana-de-açúcar. Botucatu: Instituto de Biociências, Universidade Estadual Paulista, 1995. 99 p.

ROLIM, G. S.; SENTELHAS, P. C.; BARBIERI, V. Planilhas no ambiente EXCEL para os cálculos de balanços hídricos: normal, sequencial, de cultura e de produtividade real e potencial. Revista Brasileira de Agrometeorologia, Santa Maria, v. 6, p.133, 1998.

ROSCOE, R. Agroenergia: uma nova era na agricultura brasileira. Embrapa (Empresa Brasileira de Pesquisa Agropecuária), Brasília, DF. 2006. Disponível em: <http://www.embrapa.br/embrapa/imprensa/artigos/2006/artigo >. Acesso em: jun. 2008.

ROSSIN, B.G.; TOMMASELLI, J.T.G. Efeitos do clima sobre a produção da cana-deaçúcar na região de Presidente Prudente, SP. In: 12 ENCONTRO DE GEÓGRAFOS DA AMÉRICA LATINA, 3-7 abril, 2009, Montevideo. Anais eletrônicos... Montevideo, $2009 . \quad$ Disponível em: http://www.egal2009.easyplanners.info/area07/7079_Bruna_Bruna_Gomes_Rossin.p df. Acesso em 02 mar. 2010.

ROSOLEM, C. A.. Interpretação de análise de solo e desenvolvimento radicular da cana-de-açúcar. In: SEMINÁRIO SOBRE TECNOLOGIAS DE MANEJO DO SOLO E ADUBAÇÃO DA CANA-DE-AÇÚCAR. 1994. Ribeirão Preto. Anais... Ribeirão Preto: SOPRAL SUCRESP/ALCOPLAN. 1994. p. 53-73.

RUDORFF, B.F.T. Dados Landsat na estimativa da produtividade agrícola da canade-açúcar. 1985 114f. (INPE-3744-TDL/202). Dissertação (Mestrado) - Instituto Nacional de Pesquisas Espaciais, São José dos Campos, 1985.

SAGAWARA, L.M. Estimativa de produtividade de cana-de-açúcar (Saccharum officinarum L.) por meio de técnica de análise de regressão linear múltipla. In: SIMPÓSIO BRASILEIRO DE SENSORIAMENTO REMOTO, 13, 2007. Anais... Florianópolis: INPE, 2007, p. 435-442.

SAMPAIO, E. V. S. B.; SALCEDO, J. H.; CAVALCANTE, F. J. H. Dinâmica de nutrientes em cana-de-açúcar. III conteúdo de nutrientes e distribuição do sistema radicular no solo. Pesquisa Agropecuária Brasileira, v. 22 p. 425-431, 1987.

SANT'ANNA NETO, J. L. O tempo e o clima na vida da roça. In: VILLALOBOS, J. G. (Org.). Ambiente, geografia e natureza. Maringá: UEM, 2000.

SANT'ANNA NETO, J. L. Variabilidade e tendência das chuvas no oeste paulista. Boletim Climatológico, da FCT/UNESP, Presidente Prudente, ano 1 n. 1, p. 44-56, mar. 1996.

SANTOS, M.J.Z. dos. Mudanças climáticas e planejamento agrícola. In: SANT'ANNA NETO; ZAVATINI, J. A. (Org.). Variabilidade e mudanças climáticas: implicações ambientais e socioeconômicas. Maringá: Eduem, 2000, p. 65-80.

SANTOS, M.J.Z. dos. Mudanças climáticas e a relação com a produção agrícola. Boletim Climatológico, ano 1, n. 2, Presidente Prudente: FCT/UNESP, p.51-60, 1996. 
SANTOS, M.J.Z. dos. Variabilidade e tendência da chuva e sua relação com a produção agrícola na região de Ribeirão Preto (SP). Rio Claro, SP, 1992. 389 f. Tese (Livre Docência) - Instituto de Geociências e Ciências Exatas, UNESP. 1992.

SANTOS, M.J.Z. Influências climáticas associadas às pedológicas e econômicas na produção da cana-de-açúcar nos núcleos canavieiros do estado de São Paulo. 1981. Tese (Doutorado em Geografia) - Faculdade de Filosofia, Letras e Ciências Humanas, Universidade de São Paulo, São Paulo, 1981.

SANTOS, M.J.Z. Importância da variação do regime pluviométrico para a produção canavieira na região de Piracicaba, SP. 1975. Dissertação (Mestrado em Geografia) - Faculdade de Filosofia, Letras e Ciências Humanas, Universidade de São Paulo, São Paulo, 1975.

SCARDUA, R., ROSENFELD, U. Irrigação da cana-de-açúcar. In: PARANHOS, S.B. et al. Cana-de-açúcar; cultivo e utilização. Campinas: Fundação Cargill, 1987. p. 373-431.

SCARPARI, M. S. Modelo para a previsão da produtividade da cana-de-açúcar através de parâmetros climáticos. 2002. 43 f. Dissertação (Mestrado em Agronomia) - ESALQ, Piracicaba, SP. 2002.

SEGATO, S.V.; MATTIUZ, C.F.M.; MOZAMBANI, A.E. Aspectos fenológicos da cana-de-açúcar. In: SEGATO, S.V.; PINTO, A.S.; JENDIROBA, E.; NÓBREGA, J.C.M. Atualização em produção de cana-de-açúcar, Piracicaba: CP 2, 2006. p.1936.

SILVA, A. J. N. Influência do cultivo contínuo da cana-de-açúcar em latossolos amarelos coesos do estado de Alagoas: propriedades micromorfológicas. $R$. Bras. Ci. Solo, 22:515-525, 1998.

SILVA, D.F. da; PRELA-PANTANO, A.; SANT'ANNA NETO, J.L. Variabilidade da precipitação e produtividade agrícola na região do Medio Paranapanema, SP. Rev. Bras. de Climatologia, n. 3, ano 4, p. 101-116, 2008.

SIQUEIRA, O.J.W.; STEINMETZ, S.; SALLES, L.A.B. de. Efeitos potenciais das mudanças climáticas na agricultura brasileira e estratégias adaptativas para algumas culturas. In: LIMA, M.A.; CABRAL, O.M.R.; MIGUEZ, J.D.G. Mudanças climáticas globais e a agropecuária brasileira. Jaguariúna: Embrapa Meio Ambiente, 2001. p. 33-63.

SOUZA, I.A.; GALVANI, E. Análise estatística das precipitações pluviais em região de transição climática: Maringá e Campo Mourão, PR. In: SIMPÓSIO BRASILEIRO DE CLIMATOLOGIA GEOGRÁFICA, 2008, Alto Caparaó, MG. Uberlândia: Instituto de Geociências, U FU, 2008. v. 1. p. 90-102.

SOUZA, Z.M.; et al. Variabilidade espacial da textura de um latossolo vermelho eutroférrico sob cultivo de cana-de-açúcar. Eng. Agríc., Jaboticabal, v.24, n.2, p.309319, 2004.

SPIEGEL, M.R. Probabilidade e estatística. 2 ed. New York: Mc Graw-Hill, 1985. Sugarcanecrops. Disponível em: <http://www.sugarcanecrops.com/p/growth/morphology/>. Acesso em: ago. 2008.

SUGUIO, K. As mudanças paleoclimáticas da Terra e seus registros, com ênfase no Quaternário. In: J. L. Sant'Anna Neto; J. A. Zavatini. (Org.). Variabilidade e mudanças climáticas. Maringá, PR: UEM, 2000, p. 29-49. 
TAIZ, L., E. ZEIGER. Photosynthesis: physiological and ecological considerations. In: Taiz, L.; Zeiger. E ed. Plant physiology. Reedwood-CA: The Benjamin/Cummings. 1990, p.249-264.

TARIFA, J. R. Alterações climáticas resultantes da ocupação agrícola no Brasil. Revista do Departamento de Geografia, USP, n. 8, p. 15-27, 1994.

TAUPIER, L. O. G.; RODRíGUES, G. G. A cana-de-açúcar. In: ICIDCA. Manual dos Derivados da Cana-de-Açúcar: diversificação, matérias-primas, derivados do bagaço, derivados do melaço, outros derivados, resíduos, energia. Brasília: ABIPTI, 1999. p.21-27.

TERAMOTO, E. R. Avaliação e aplicação de modelos de estimativa de produção de cana-de-açúcar (Saccharum spp), baseados em parâmetros do solo e clima. Piracicaba, 2003, 86f. Tese (Doutorado) - ESALQ/USP, São Paulo, 2003.

TERUEL, D.A.; DOURADO NETO, D.; HOPMANS, J.W.; REICHARDT, K. Modelagem matemática como metodologia de análise do crescimento e arquitetura de sistemas radiculares. Sci. agric. vol.57 n. 4, Piracicaba, p. 683-691, 2000.

THORNTHWAITE, C.W.; MATHER, J.R. The water balance. Publications in climatology. New Jersey: Drexel Institute of Technology, 1955. 104p.

UNICA - União da Agroindústria Canavieira de São Paulo. Cana-de-açúcar: origem da atividade. Disponível em: <http://www.unica.com.br/pages/cana>. Acesso em: Mar. 2007.

USDA-United States Department of Agriculture USDA 2005. Statistics of cotton, tobacco, sugar crops and honey. Disponível em: $<$ http://www.fas.usda.gov/htp/sugar/sugar.asp $>$. Acesso em: Fev. 2008.

VALIO, D.A. et. al. Variabilidade climática e transformação no uso do solo do extremo oeste paulista. In: SIMPÓSIO DE CLIMATOLOGIA GEOGRÁFICA. 2002, Curitiba. Anais... Curitiba: UFPR, 2002.

VILLA NOVA, N.A. et al. Um modelo de avaliação do crescimento de cana-de-açúcar (Saccharum spp.) em termos da ação combinada do fotoperíodo e da temperatura média do ar. In: CONGRESSO BRASILEIRO DE AGROMETEOROLOGIA 2, 1983, Campinas. Anais... Campinas: Sociedade Brasileira de Agrometeorologia, 1983. p. 31-48.

WADSTED, O.G. O clima e a economia: análise de algumas culturas no estado de São Paulo. Rio de Janeiro. Revista Brasileira de Economia. v. 37, n. 2, p. 225-244, 1983.

WREGE, M. S. et al. Regiões potenciais para cultivo da cana-de-açúcar no Paraná, com base na análise do risco de geadas. Revista Brasileira de Agrometeorologia, Santa Maria, v. 13, n. 1, p. 113-122, 2005.

ZAMPIERI, D. Desempenho 2005 e perspectiva 2006. Disponível em: $<$ http//seab.pr.gov.br>. Acesso em: Mar. 2006.

ZAVATINI, J.A. Variação no ritmo pluvial no oeste de São Paulo e norte do Paraná: eixo Araçatuba, Presidente Prudente e Londrina. 1983. Dissertação (Mestrado em Geografia) - FFLCH/USP, São Paulo, 1983.

ZINK, F. Cultura da cana-de-açúcar. Campinas: CATI, 1978. 16p. 